\title{
Operable Unit 3-13, Group 7, SFE-20 Hot Waste Tank System Remedial Action Report
}

June 2009 

DOE/ID-11391

Revision 0

Project No. 23052

\section{Operable Unit 3-13, Group 7, SFE-20 Hot Waste Tank System Remedial Action Report}

June 2009

Prepared for the

U.S. Department of Energy

DOE Idaho Operations Office 



\section{ABSTRACT}

This Remedial Action Report summarizes activities undertaken to remediate the Operable Unit 3-13, Group 7, SFE-20 Hot Waste Tank System at the Idaho Nuclear Technology and Engineering Center at the Idaho National Laboratory Site. The site addressed in this report was defined in the Operable Unit 3-13 Record of Decision and subsequent implementing documents. This report concludes that remediation requirements and cleanup goals established for the site have been accomplished and is hereafter considered a No Further Action site. 


\section{CONTENTS}

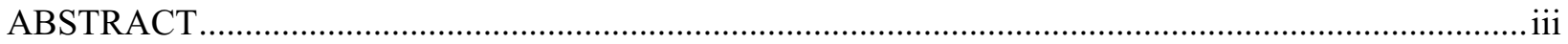

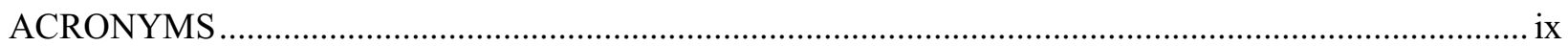

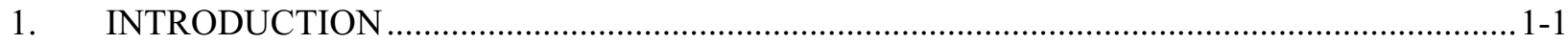

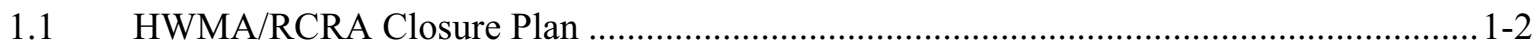

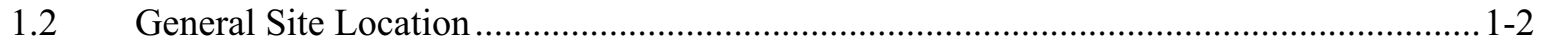

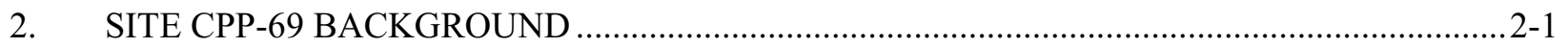

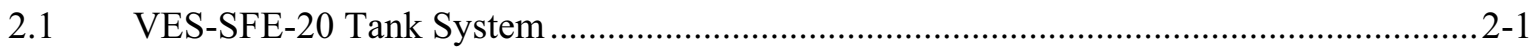

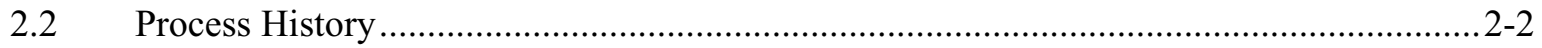

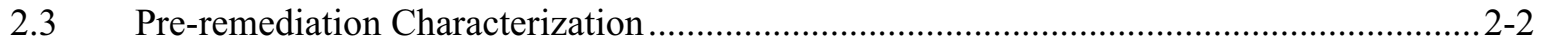

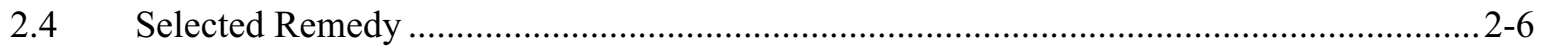

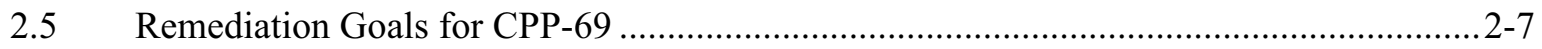

3. REMEDIATION AND DEMOLITION ACTIVITIES ….......................................................

3.1 Phase I: Removal of the Tank and Contents................................................................

3.2 Phase II: Removal of Remaining Components and Vault ............................................ 3-1

3.3 VES-SFE-20 Tank and Contents Treatment and Disposal............................................. 3-2

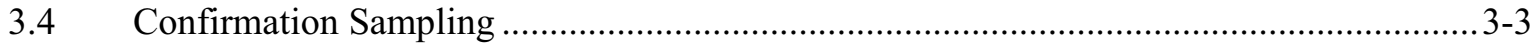

3.4.1 Confirmatory Sampling Data Summary ....................................................... 3-5

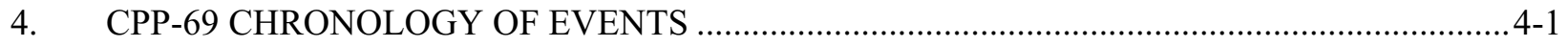

5. PERFORMANCE STANDARDS AND CONSTRUCTION QUALITY CONTROL...................5-1

5.1 Performance Comparison with Remedial Action Objectives and Remediation Goals ......5-1

5.1.1 External Exposure Risk ........................................................................ $5-1$

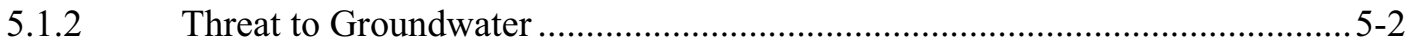

6. CPP-69 FINAL INSPECTION AND CERTIFICATION ….....................................................

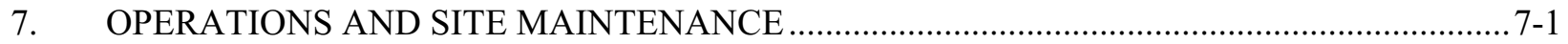

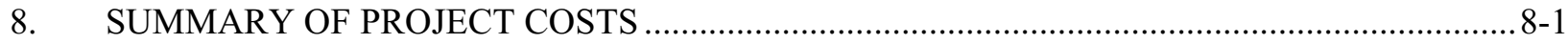

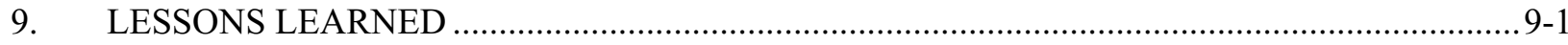

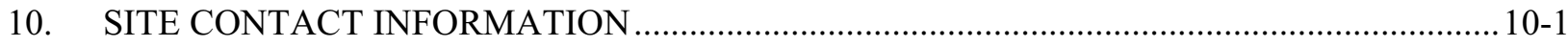

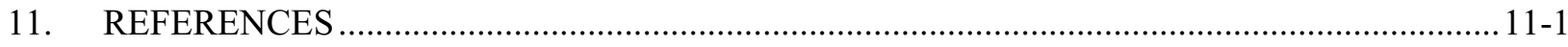

Appendix A-Removal of the Tank and Contents .............................................................................. A-1

Appendix B — Removal of Pump Pit, Tunnel and Vault ...................................................................... B-1

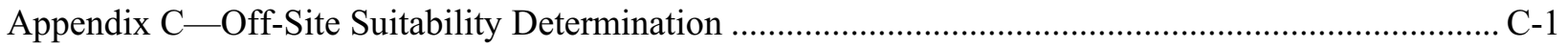

Appendix D-Manifest and Land Disposal Restriction Certifications................................................ D-1

Appendix E — Certification of Disposal ....................................................................................... E-1 
Appendix F-VES-SFE-20 Tank and Contents Treatment and Disposal ….......................................

Appendix G-SFE-20 Soils Confirmation Sampling Results ............................................................. G-1

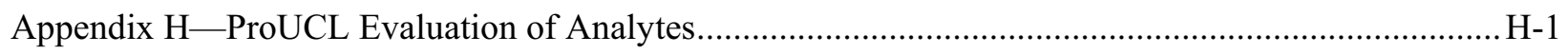

\section{FIGURES}

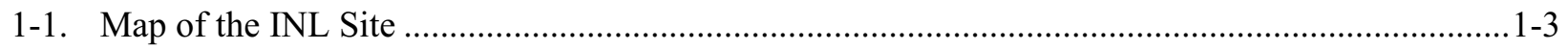

1-2. Location of the VES-SFE-20 tank in WAG 3 …...................................................................

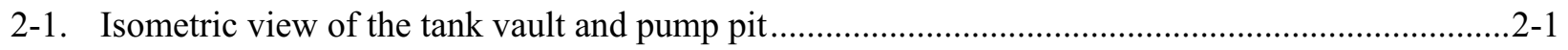

2-2. Photograph of tank and interior of vault taken during 1984 entry .............................................2-3

2-3. Image of sediment at the bottom of the VES-SFE-20 tank .......................................................2-3

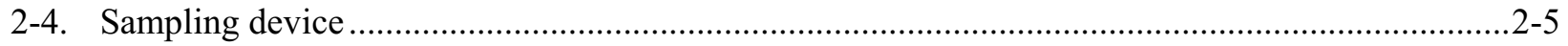

2-5. Still image of sediments within the VES-SFE-20 tank after sampling attempts were made ..........2-5

2-6. Detail of still image of sediments within the VES-SFE-20 tank after sampling attempts

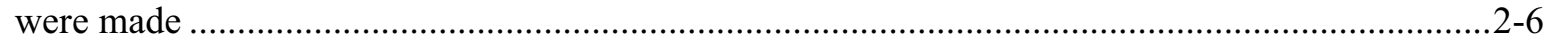

3-1. CPP-69 SFE-20 confirmation sampling locations …..................................................................

\section{TABLES}

2-1. Soil risk-based remediation goals (verbatim from DOE-ID 1999) ...........................................2-8

2-2. SRPA remediation goals (verbatim from DOE-ID 1999) .............................................................

3-1. Contaminants of potential concern for VES-SFE-20 tank system .................................................3-3

3-2. Contaminants of potential concern removed from list of contaminants sampled ...........................3-4

3-3. Final list of contaminants of concern, analytical methods, and detection limits.............................3-4

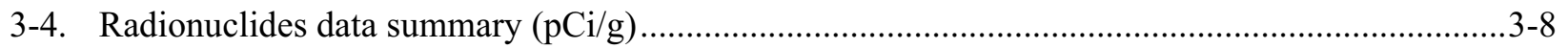

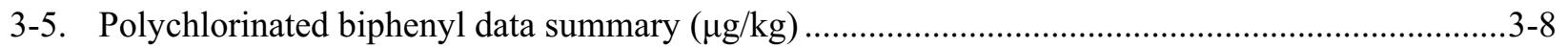

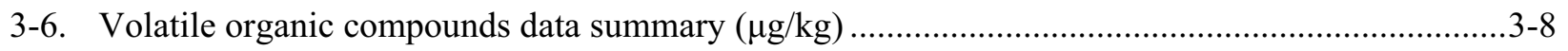

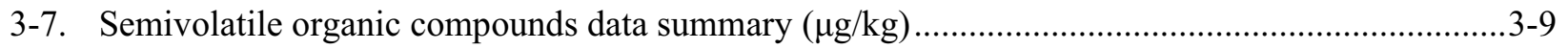

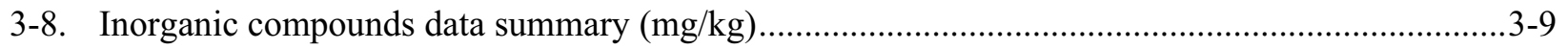

4-1. Chronology of events for the CPP-69 project ...........................................................................

5-1. Comparison of contaminant concentrations with external risk remediation goals..........................5-2

5-2. Comparison of inorganic constituents to INL Site soil background levels ..................................5-3

5-3. Comparison of radionuclides to INL Site soil background levels................................................5-3

5-4. Inorganic contaminant concentrations compared to screening levels .........................................5-4

5-5. Organic contaminant concentrations compared to screening levels.............................................5-4

5-6. Comparison of radionuclide concentrations to EPA Region IX SSLs .........................................5-4 
5-7. Half-lives of remaining radionuclides.

5-8. Estimated travel time through sediments versus half-life .....

5-9. Comparison of Sr-90 concentration with OU 3-14 modeled concentration. .5-5

8-1. Cost summary of remedial actions for CERCLA Group 7 Site CPP-69. 8-1

10-1. Contact information for the CPP-69 project 10-1 


\section{ACRONYMS}

CERCLA Comprehensive Environmental Response, Compensation, and Liability Act

COPC contaminant of potential concern

CWP characterization work plan

EPA U.S. Environmental Protection Agency

FFA/CO Federal Facility Agreement and Consent Order

FSP field sampling plan

HWMA Hazardous Waste Management Act

ICDF Idaho CERCLA Disposal Facility

INL Idaho National Laboratory

INTEC Idaho Nuclear Technology and Engineering Center

NTS Nevada Test Site

OU operable unit

Pecos Pacific EcoSolutions, Incorporated

PEW process equipment waste

QAPjP Quality Assurance Project Plan

RA remedial action

RAO remedial action objective

RCRA Resource Conservation and Recovery Act

$\mathrm{RD} \quad$ remedial design

ROD Record of Decision

SSL soil screening level

SRPA Snake River Plain Aquifer

TRU transuranic

UCL upper confidence limit

WAC Waste Acceptance Criteria

WAG waste area group

WP work plan 


\section{Operable Unit 3-13, Group 7, SFE-20 Hot Waste Tank System Remedial Action Report}

\section{INTRODUCTION}

In accordance with the Federal Facility Agreement and Consent Order for the Idaho National Engineering Laboratory ${ }^{\mathrm{a}}$ (FFA/CO) (DOE-ID 1991), the U.S. Department of Energy Idaho Operations Office submits this Group 7 Remedial Action (RA) Report for the Vessel-Storage Facility Exterior-20 (VES-SFE-20) Hot Waste Tank System within the Waste Area Group (WAG) 3. The RA activities identified in this report, as part of the Comprehensive Environmental Response, Compensation and Liability Act (CERCLA) process, were performed in accordance with the signed Operable Unit (OU) 3-13 Record of Decision (ROD) (DOE-ID 1999) and the Group 7 Remedial Design (RD)/RA Work Plan (WP) for WAG 3, OU 3-13 (DOE-ID 2008). This RA Report documents the construction and operations phases for remediation of the VES-SFE-20 Hot Waste Tank System and the final configuration of the site.

WAG 3 is a collection of contamination sites at the Idaho Nuclear Technology and Engineering Center (INTEC) at the Idaho National Laboratory (INL) Site. Over years of operation, releases of radioactive and hazardous materials to the environment occurred, which later were grouped together and collectively identified as WAG 3. Because of significant differences between the various release sites at INTEC, WAG 3 was divided into 14 OUs. OU 3-13 is divided into seven groups. The seven groups are:

- $\quad$ Tank Farm Soils (Group 1)

- $\quad$ Soils Under Buildings and Structures (Group 2)

- $\quad$ Other Surface Soils (Group 3)

- $\quad$ Perched Water (Group 4)

- $\quad$ Snake River Plain Aquifer (Group 5)

- $\quad$ Buried Gas Cylinders (Group 6)

- $\quad$ SFE-20 Hot Waste Tank System (Group 7).

Group 7 (also known as release site CPP-69) consisted of a concrete vault containing an abandoned radioactive liquid waste tank (referred to as VES-SFE-20), an access tunnel, a pump pit, CPP-642 pump house, ancillary piping and structures and components, and contaminated soils associated with releases from the tank. For this document, the entire system will be referred to as the VES-SFE-20 tank system; VES-SFE-20 will be used to specifically reference the tank. The tank contained about 33 gal of radioactive sediment. As part of the CERCLA process mandated by the FFA/CO (DOE-ID 1991), the investigation and remediation approach for Group 7 was evaluated through the OU 3-13 remedial investigation and feasibility study process. As documented in the OU 3-13 ROD, the selected remedial approach for Group 7 was to remove the tank and its contents; the vault; the remainder of the structures, piping, and other components; and surrounding contaminated soils and transport them for either on-Site or off-Site storage or disposal.

a. In 1997 the Idaho National Engineering Laboratory was renamed the Idaho National Engineering and Environment Laboratory (INEEL). In February 2005, the INEEL became the Idaho National Laboratory (INL). In May 2005, the INL was split into the Idaho Cleanup Project (ICP) for environmental remediation activities and the INL for all other activities. The physical area that was the INEEL is now the INL Site. 


\subsection{HWMA/RCRA Closure Plan}

The State of Idaho approved and modified a Hazardous Waste Management Act (HWMA)/Resource Conservation and Recovery Act (RCRA) Closure Plan for the VES-SFE-20 Hot Waste Tank System in May 2002. This Closure Plan was revised in October 2002 and again in June 2003. (DEQ 2003). The CERCLA remediation of the VES-SFE-20 tank system was planned in a manner to meet the CERCLA objectives and also satisfy the additional requirements imposed by the HWMA/RCRA Closure Plan.

HWMA/RCRA closure of the VES-SFE-20 tank system occurred in accordance with the State of Idaho HWMA/RCRA Closure Plan (DEQ 2003). That plan provided the HWMA/RCRA, IDAPA 58.01.05.009 (40 CFR 265, Subpart G) closure requirements and methods for achieving the closure performance standards. The closure was performed in conjunction with the CERCLA remediation of the VES-SFE-20 tank system. Both the remedy required under the OU 3-13 ROD and the closure of the tank system under the Closure Plan were protective of human health and the environment and prevented future releases of hazardous constituents and radionuclides into the environment.

The contaminants of potential concern (COPCs), identified in Section 3.1 of the Closure Plan, included cadmium; chromium; acetone; methylene chloride; 1,1,1-trichloroethane; tetrachlorothene; and formaldehyde. The data from the tank characterization activities identified some of the hazardous constituents of concern at levels that triggered hazardous waste regulations. The tank and contents were consequently treated and disposed of off-Site as required by the CERCLA Work Plan and the Closure Plan.

\subsection{General Site Location}

The INTEC is a facility located within the INL Site in southeastern Idaho near Idaho Falls (see Figure 1-1). Operations at INTEC (formerly the Chemical Processing Plant; see Figure 1-2 for location

at that site) began in 1952 and continue to the present. The VES-SFE-20 tank system was constructed in 1957 to collect radiologically contaminated liquids from floor drains in Building CPP-603. 


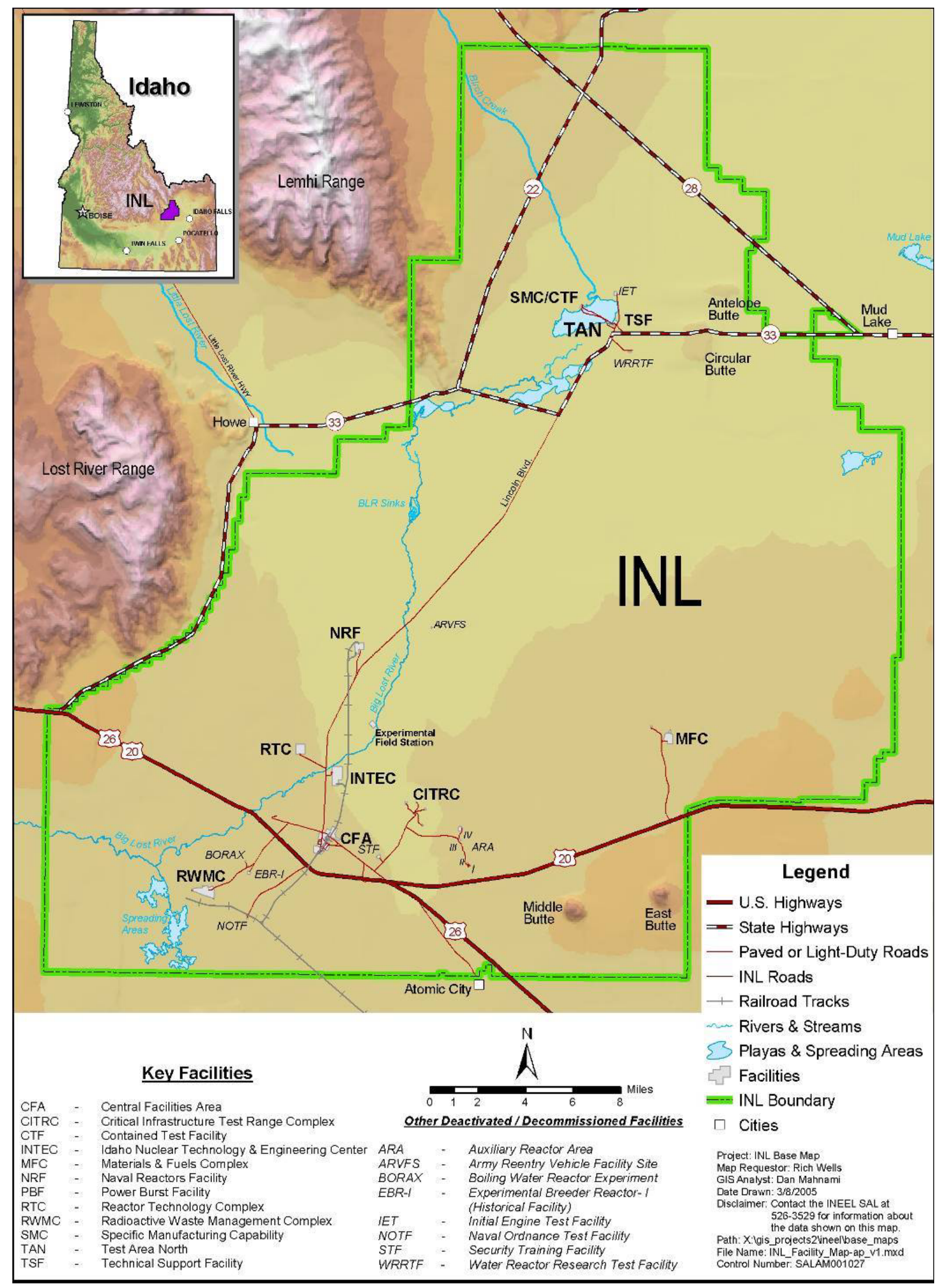

Figure 1-1. Map of the INL Site. 


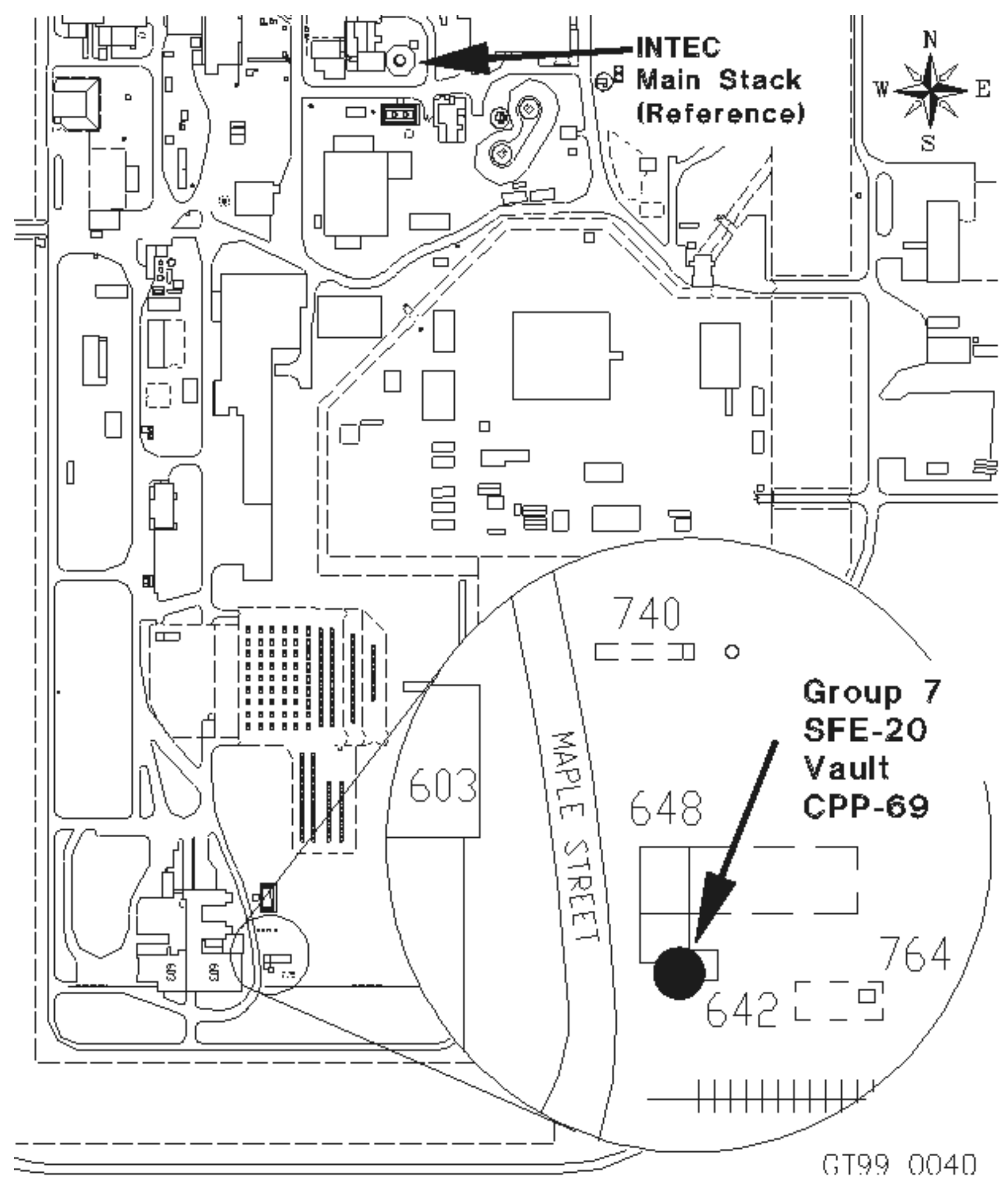

Figure 1-2. Location of the VES-SFE-20 tank in WAG 3. 


\section{SITE CPP-69 BACKGROUND}

\subsection{VES-SFE-20 Tank System}

The VES-SFE-20 tank system was located east of Building CPP-603 (Figure 1-2). The capacity of the SFE-20 tank was 640 gal. The tank was approximately $9.5 \mathrm{ft}$ long and $3.5 \mathrm{ft}$ in diameter. The vault and other major components of the VES-SFE-20 tank system are shown in Figure 2-1. The utility lines (air, water, steam, condensate, electrical conduit, etc.) that fed the VES-SFE-20 tank and that transported the waste to the Process Equipment Waste (PEW) Evaporator Facility were isolated from this tank and incorporated into other tank systems when the use of the VES-SFE-20 tank was discontinued in 1976. The remediation of the VES-SFE-20 tank system was designed to occur in two remedial phases. This phased approach allowed for removal of the tank and waste, while providing flexibility for coordination of the removal of the vault and associated structures and soils with other related RAs in that area, such as the WAG 3, Group 3-Other Surface Soils.

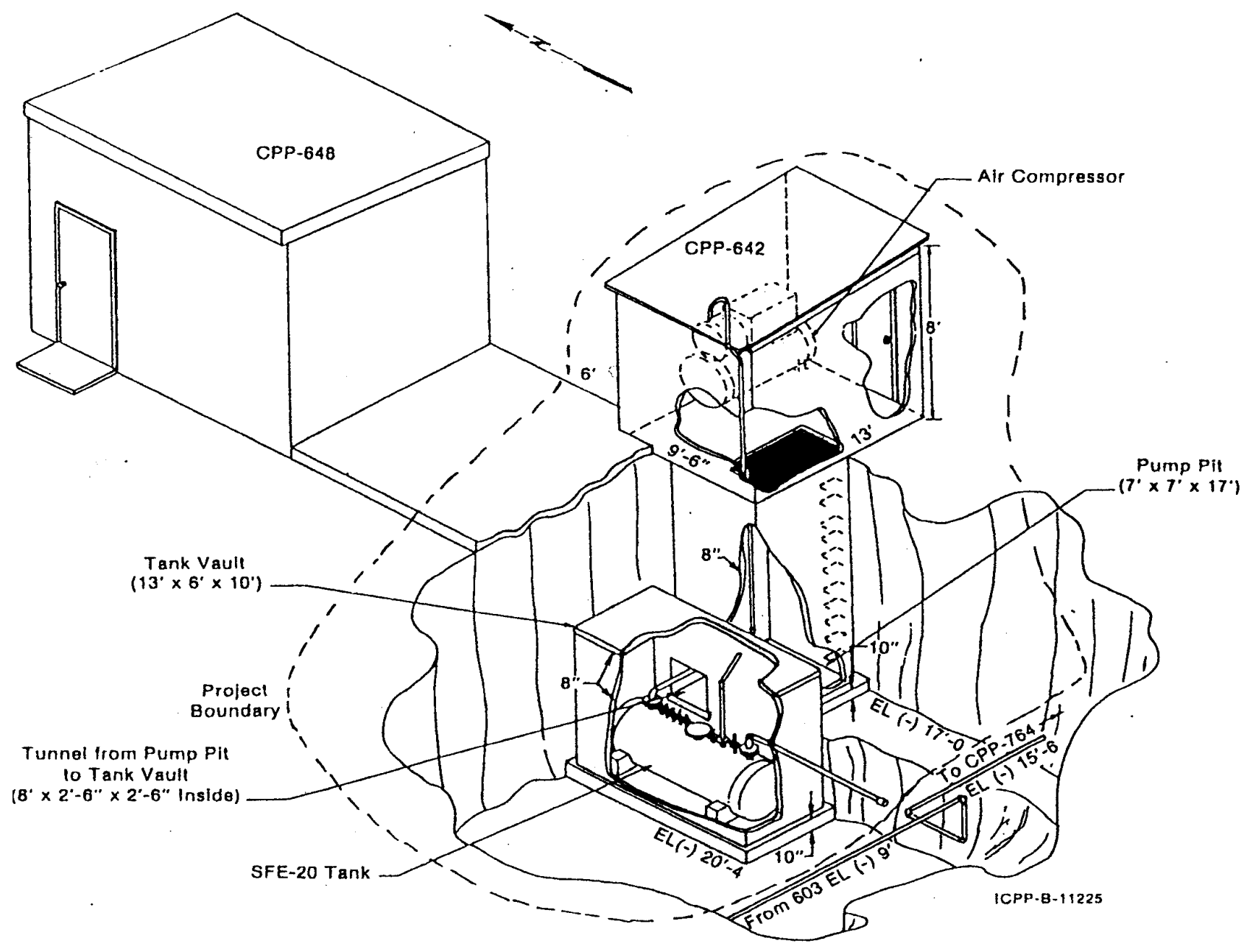

Figure 2-1. Isometric view of the tank vault and pump pit. 


\subsection{Process History}

The Fuel Element Cutting Facility in CPP-603 south basin area sent radioactive liquid waste from the floor drains to the VES-SFE-20 tank. This facility was used to cut aluminum-clad fuel originating from a test reactor at the Savannah River Facility. The Fuel Element Cutting Facility conducted fuel-cutting operations beginning in 1959 and ending in 1962. Liquid waste collected in the VES-SFE-20 tank was then pumped to the PEW Evaporator Facility for treatment. At the conclusion of fuel-cutting activities, acid was added to the tank, and the tank was heated to dissolve fine cuttings in the tank and lines that had passed through the strainers in the floor drains. This solution was then pumped to the PEW facility for treatment. In addition, the tank received backwash water from the filter system that removed contaminants from the CPP-603 basin water. These contaminants included radionuclides from leaking fuel casks. In 1976, primarily due to the insufficient working capacity of the VES-SFE-20 tank, it was removed from service and replaced with the larger-capacity VES-SFE-126 tank. The VES-SFE-20 tank has not been used since.

The various entries made and conditions found in the pump pit, tunnel, and vault clearly indicated some waste releases from the tank and piping systems inside the structures (nonquantified), but the past external and internal examinations of the tank showed it to be in excellent condition. Also, during remediation, there were no indications of releases from the concrete containment structures to the surrounding soils.

Building CPP-642 was not in operation but contained utilities and transfer lines that supported adjacent waste holding tanks (VES-SFE-106/126), which routed through CPP-642 and above the tank vault and access tunnel.

\subsection{Pre-remediation Characterization}

Past characterization efforts included preliminary radiological measurements and analysis for samples collected from the pump pit, access tunnel, and vault and videotaped conditions within the tank and vault. The following is a summary of the past characterization activities:

- $\quad$ No subsurface core samples were taken of the soils above the VES-SFE-20 tank due to the buried lines and conduits in the area. However, in 1976, an excavation was performed to cut and cap the inlet pipe to VES-SFE-20 (2 m [7 ft] south of the tank vault) and route the line to the new VES-SFE-126 tank. A common INTEC practice was to backfill, to within 0.9 to $1.2 \mathrm{~m}$ (3 to $4 \mathrm{ft})$ of the surface, with the slightly contaminated soils encountered during excavation. Therefore, there is a possibility that the subsurface soil near the south end of the VES-SFE-20 tank vault is contaminated.

- In 1984, the contents of the VES-SFE-20 tank - approximately $208 \mathrm{~L}$ (55 gal) of sediment and approximately 1,514 L (400 gal) of liquid - were sampled for radiological content only (WINCO 1984). Those analytical results can be found in the Characterization Work Plan for the VES-SFE-20 Hot Waste Tanks at INTEC (CWP) (DOE-ID 2003a). The sediment samples from the bottom of the tank were evaluated for $\mathrm{Pu}-238$ and $\mathrm{Pu}-239$, and a combined concentration of 93.5 nCi of Pu-238/239 per gram of sediment was determined. Because of the decay of Pu to other transuranic (TRU) materials and the presence of other materials that are always present in spent fuel material (most notably Np and Am), a revised estimate of the total TRU curie content in the sediment was made. This estimate was made based on knowledge that the source for the radioactive material was cuttings from Savannah River Plant spent fuel assemblies and the age of the material was approximately 25 years. Based on this information, the revised estimate for the sediment material was $117 \mathrm{nCi} / \mathrm{g}(\mathrm{EDF}-2360)$. 
- $\quad$ An entry into the VES-SFE-20 tank vault was performed in 1991 to evaluate conditions in preparation for decontamination and dismantlement work; however, no further action was taken. The 1991 entry was videotaped and provided information on general conditions in the vault.

- In June 2002, a remote camera entry was made into the VES-SFE-20 tank. Upon camera entry into the tank, it was noted that there was no visible standing liquid in the tank, although some clear fluid (assumed to be condensate) was dripping into the tank. No formal record has been found to indicate what may have occurred to explain the absence of the liquid that was present in the tank in 1984 (see Figure 2-2). The camera was lowered to touch the top of the sediment, and, based on marked measurements on the camera cord and the diameter of the tank, the sediment was determined to be 3-4 in. in depth. Upon removing the camera from the vent line, residual sediment on the camera provided a color and physical consistency similar to that of wet clay soil native to the INL Site. An image of the sediment within the tank is shown in Figure 2-3 (blue tint in Figure 2-3 is a result of auxiliary lighting provided for the camera).

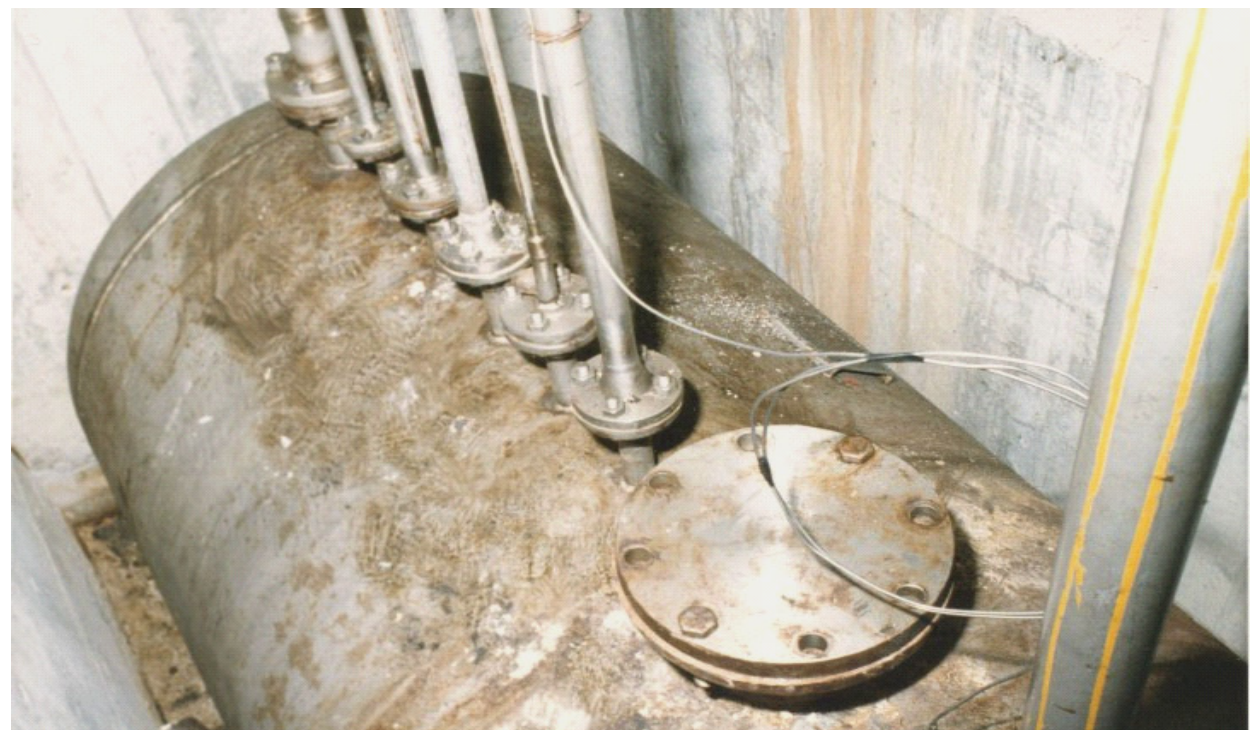

Figure 2-2. Photograph of tank and interior of vault taken during 1984 entry.

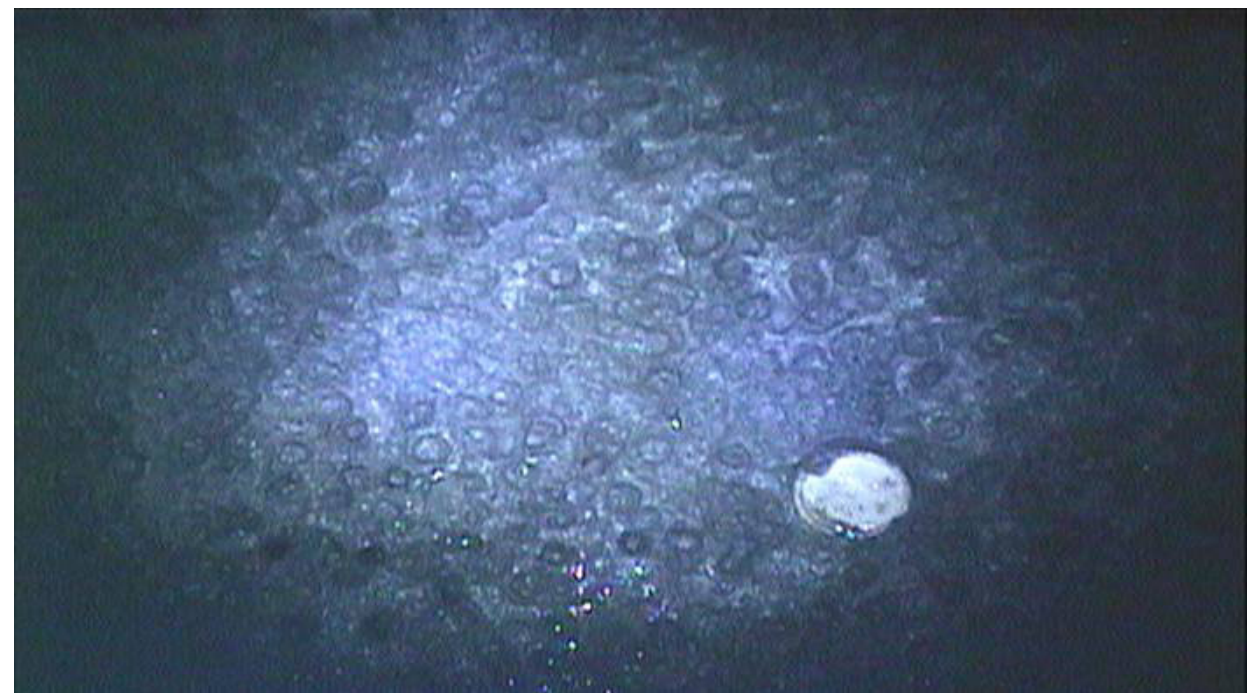

Figure 2-3. Image of sediment at the bottom of the VES-SFE-20 tank. 
- In July 2002, a remote camera entry was made into the VES-SFE-20 tank vault. This remote inspection revealed no standing water at the base of the vault and showed the integrity of the tank is similar to that shown in the 1984 inspection of the tank vault (see Figure 2-2).

- In November 2002, radiation readings inside the tank were obtained by inserting an HP290 radiation detector into the tank through the vent line. The readings were taken using an Eberline E600 instrument. The radiation levels measured were as follows:

\begin{tabular}{lcc}
\multicolumn{1}{c}{ Location } & Reading \\
\cline { 1 - 1 } Vent line, $12 \mathrm{ft}$ into pipe (1 $1^{\text {st }} 90$-degree turn) & & $<1 \mathrm{mR} / \mathrm{h}$ \\
Vent line, 22 ft into pipe (2 ${ }^{\text {nd }}$ 90-degree turn) & & $60 \mathrm{mR} / \mathrm{h}$ \\
(near) Tank entry, 26 ft into pipe & $1.5 \mathrm{RR} / \mathrm{h}$ \\
$1 \mathrm{ft}$ into tank & $2.67 \mathrm{R} / \mathrm{h}$ \\
$2 \mathrm{ft}$ into tank & $5.7 \mathrm{R} / \mathrm{h}$ \\
$3 \mathrm{ft}$ into tank & $6.3 \mathrm{R} / \mathrm{h}$
\end{tabular}

Additionally, sampling for lower explosive limit, $\mathrm{CO}, \mathrm{NO}, \mathrm{NO}_{2}$, and $\mathrm{O}_{2}$ was performed using an Industrial Scientific iTX instrument. The instrument ran for 17 minutes. An $\mathrm{H}-\mathrm{Nu}$ photo-ionization detector was then run for 5 minutes after the iTX for total organics. The results are as follows:
$0 \%$ lower explosive limit
0 ppm NO
$20.7 \% \mathrm{O}_{2}$
0 ppm CO
$0.0 \mathrm{ppm} \mathrm{NO}_{2}$
6 ppm max total organics

Total organic results from this specific test were used to assess the airborne exposure to organic compounds only and not for analytical purposes.

- On January 14, 2003, a sampling effort was conducted to obtain a sample of the tank sediment for characterization analysis. This sampling effort utilized the 2 -in. vent line to access the sediment. Several attempts were made to gather a sample with the sampling device shown in Figure 2-4. The device was attached to a tether made of several small plastic tubes containing wire that are encased in an expandable nylon wrapping and sent down the vent line. These attempts were unsuccessful due to the consistency of the sediment.

Based on those results, a second attempt to obtain a sample was made on January 21, 2003, using newly developed sharp tips for the sampling tool. Several attempts were made to collect a sample; however, none were successful. The following day, a video camera was sent back down the vent line to try and assess the surface condition of the sediment. The inspection showed depressions in the sediment and evidence of the sample tool being in contact with the material (see Figures 2-5 and 2-6). Since the previous attempts were unsuccessful through the vent line, a decision was made to proceed to a manned entry sampling process. 


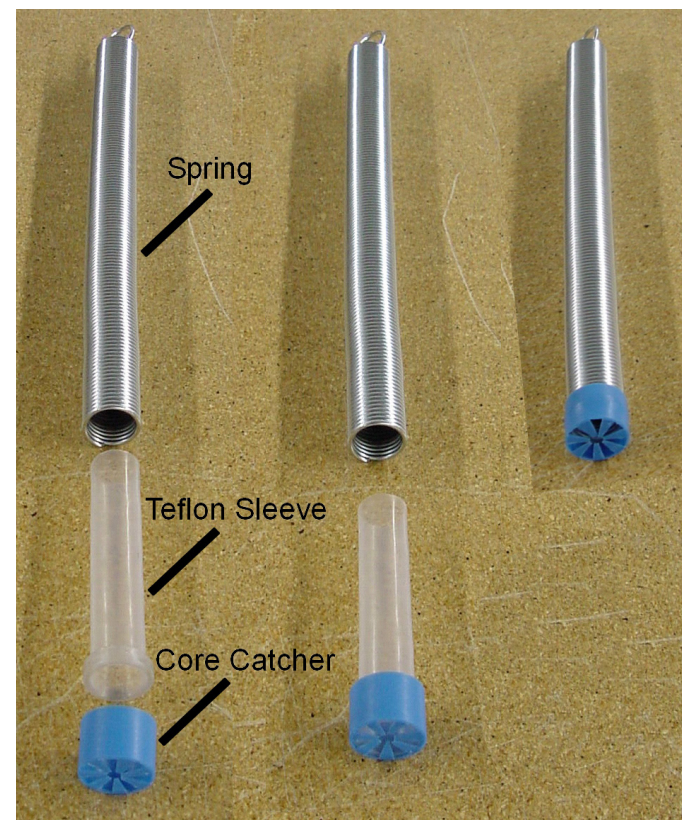

Figure 2-4. Sampling device.

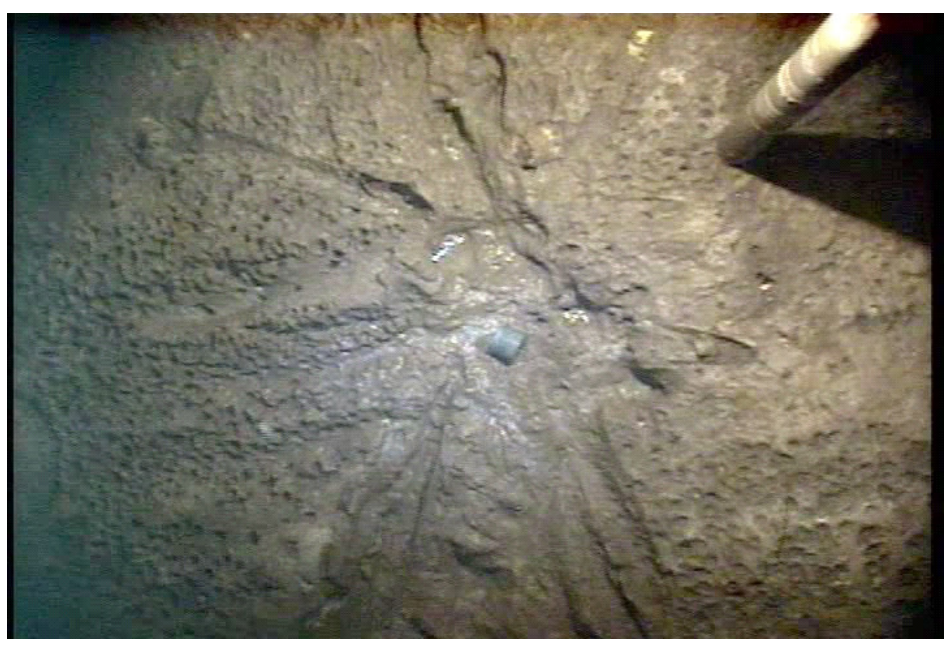

Figure 2-5. Still image of sediments within the VES-SFE-20 tank after sampling attempts were made. 


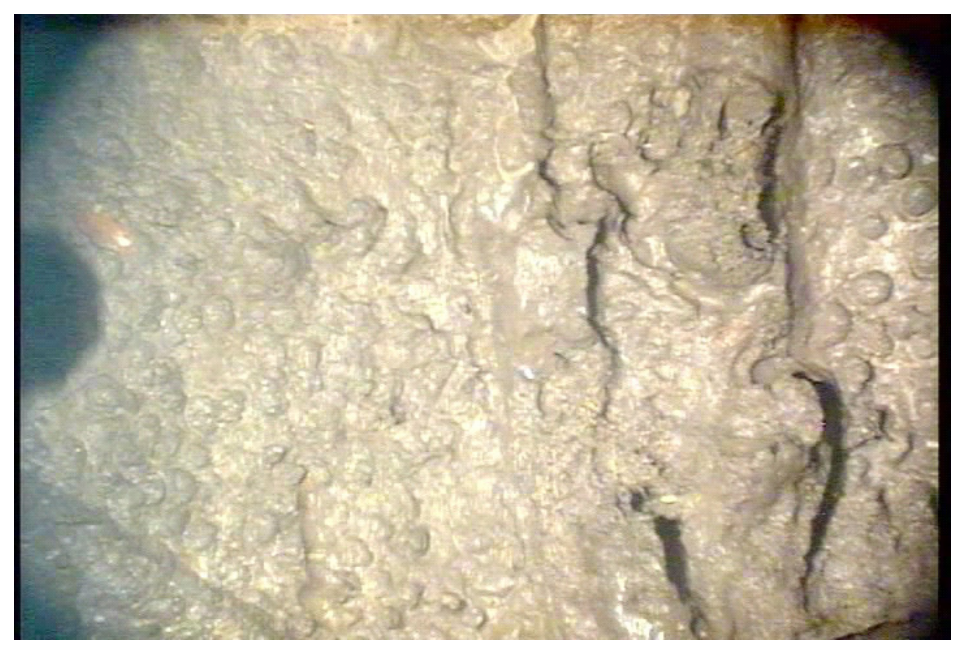

Figure 2-6. Detail of still image of sediments within the VES-SFE-20 tank after sampling attempts were made.

- On February 21, 2003, a manned entry into the VES-SFE-20 pump pit and vault was attempted to collect samples from the tank. A survey of the pump pit was completed. Upon surveying the VES-SFE-20 tank vault, the radiation fields were found to be higher than expected. The radiation levels exceeded the safe limits as documented in the radiological work permit; thus, the work was stopped due to unsafe work conditions. The Agencies were notified and it was later agreed that sampling of the tank contents would take place during Phase I remediation efforts upon exhumation of the tank. Sampling of the tank was covered in the CWP (DOE-ID 2003a).

\section{$2.4 \quad$ Selected Remedy}

The selected remedy for the VES-SFE-20 Hot Waste Tank System, as identified in the Final Record of Decision, Idaho Nuclear Technology and Engineering Center, OU 3-13 (DOE-ID 1999) was removal, treatment, and disposal. The remedy was selected based on the following evaluation criteria: protection of human health and the environment; compliance with applicable or relevant and appropriate requirements; long- and short-term effectiveness; reduction of toxicity, mobility, or volume of contaminants; implementability; and cost. The remedy consisted of:

- Institutional controls (i.e., warning signs) until removal of the tank liquid and sludge

- $\quad$ Sampling the tank contents

- $\quad$ Removal and ex situ treatment of the tank liquid and sludge

- Excavation and removal of the tank, tank vault, pump pit enclosures, other associated structures

- $\quad$ On-Site disposal of the tank and associated structures.

Section 11.1.7 of the OU 3-13 ROD stated that, following characterization, the tank liquid be removed and treated at the PEW evaporator if it met the specified waste criteria. The ROD assumed that the liquid within the SFE-20 tank would meet the PEW Waste Acceptance Criteria (WAC) but noted that if the PEW was unable to accept the liquid waste or was unavailable at the time the response action is conducted, a small portable evaporator unit would be utilized on-Site; or the waste would be disposed of off-Site in accordance with the off-Site Rule (40 CFR 300.440). Additionally, the OU 3-13 ROD declaration specified the following: 
- $\quad$ Land-dispose treated waste, tank, vault, and other debris. The preferred disposal site is the Idaho CERCLA Disposal Facility (ICDF); however, if any residue or material fails to meet the ICDF WAC, an alternate suitable disposal facility will be identified during the RD.

- $\quad$ Remove and treat off-Site, if wastes found in the tank are alpha low-level waste (i.e., exceed $10 \mathrm{nCi} / \mathrm{g}$ TRU constituents [alpha emitters with an atomic number greater than 92 and a half-life exceeding 20 years]) or TRU wastes (i.e., greater than $100 \mathrm{nCi} / \mathrm{g}$ TRU).

\subsection{Remediation Goals for CPP-69}

The remedial action objective (RAO) for the VES-SFE-20 tank system (Group 7), OU 3-13, was developed in accordance with the National Contingency Plan and CERCLA Remedial Investigation/Feasibility Study guidance and defined in the ROD (DOE-ID 1999). The RAO was primarily based on the results of the baseline risk assessment and applicable or relevant and appropriate requirements, as outlined in the ROD.

Table 2-1 below was taken verbatim from Table 8-1 in the ROD (DOE-ID 1999). It provided the soil risk-based remediation goals, from the OU 3-13 ROD, for each of the contaminants of concern. Table 2-2, also taken verbatim from the ROD (Table 8-2), identified the Snake River Plain Aquifer (SRPA) remediation goals. These remediation levels were used as the cleanup requirements for this remediation effort.

The following RAO was developed to protect human health and the environment:

- $\quad$ Eliminate the threat of release to the SRPA posed by the VES-SFE-20 Hot Waste Tank System.

Section 8.1.7 of the OU 3-13 ROD identified the remediation goals for the SFE-20 tank system as follows:

1. Limit potential external exposures to workers and nonworkers

2. Remove radioactive and hazardous substances remaining in the tank system to prevent potential contaminant releases to the underlying soils or groundwater.

As specified in the ROD, these remediation goals were to be accomplished by:

1. Maintaining existing institutional controls to limit current worker and nonworker exposure

2. Removing, excavating, treating, and disposing of the SFE-20 Hot Waste Tank System waste and components to eliminate the threat of release to the environment (waste that meets the ICDF WAC will be disposed of in the ICDF)

3. Remediating contaminated soils present beneath the SFE-20 tank system that may pose an external exposure risk or threat to groundwater (waste that meets the ICDF WAC will be disposed of in the ICDF).

The ROD identified that these remediation goals also support the "Other Areas RAO 5a" that is "to eliminate the threat of release to the SRPA posed by the SFE-20 Hot Waste Tank System." Also supported was the groundwater RAOs for INTEC-impacted groundwater (located in the groundwater contaminant plume outside of the current INTEC security fence) to restore the aquifer for use by 2095 and beyond so that: (a) risk will not exceed a cumulative carcinogenic risk of $1 \times 10^{-4}$ for groundwater ingestion, (b) the aquifer will be restored to drinking water quality (below maximum contaminant levels), and (c) the noncarcinogenic risk will not exceed a total hazard index of 1 for groundwater ingestion. 
Table 2-1. Soil risk-based remediation goals (verbatim from DOE-ID 1999).

\begin{tabular}{|c|c|c|}
\hline & Contaminant of Concern & $\begin{array}{l}\text { Soil Risk-Based Remediation Goal } \\
\text { for Single COCs } \\
(\mathrm{pCi} / \mathrm{g} \text { or } \mathrm{mg} / \mathrm{kg})\end{array}$ \\
\hline \multicolumn{3}{|c|}{ Radionuclides } \\
\hline & Am-241 & 290 \\
\hline & Cs-137 & 23 \\
\hline & Eu-152 & 270 \\
\hline & Eu-154 & 5200 \\
\hline & $\mathrm{Pu}-238$ & 670 \\
\hline & $\mathrm{Pu}-239 / 240$ & 250 \\
\hline & $\mathrm{Pu}-241$ & 56,000 \\
\hline & Sr-90 & 223 \\
\hline \multicolumn{3}{|c|}{ Nonradionuclides $^{\mathrm{c}}$} \\
\hline & Mercury (human health) & 23 \\
\hline \multicolumn{3}{|c|}{$\begin{array}{l}\text { a. Source of risk-based soil remediation goals: Table 2-1 of the OU 3-13 FS (DOE-ID 1997). Risk-based remediation goals } \\
\text { developed for residential scenario. } \\
\text { b. If multiple contaminants are present, use a sum of the fractions to determine the combined COC remediation goal. } \\
\text { c. The mercury remediation goal was selected from the EPA Region 3, April 1996, screening guidance for soil ingestion under the } \\
\text { residential scenario. (EPA 1996). }\end{array}$} \\
\hline $\begin{array}{l}\text { COC } \\
\text { EPA } \\
\text { FS } \\
\text { OU } \\
\end{array}$ & $\begin{array}{l}\text { contaminant of concern } \\
\text { U.S. Environmental Protection Agency } \\
\text { feasibility study } \\
\text { operable unit }\end{array}$ & \\
\hline
\end{tabular}

Table 2-2. SRPA remediation goals (verbatim from DOE-ID 1999).

\begin{tabular}{lll}
\multicolumn{1}{c}{ Contaminant of Concern } & \multicolumn{1}{c}{$\begin{array}{c}\text { SRPA Remediation Goals } \\
\text { (Maximum Contaminant Levels) } \\
\text { for Single COCs }{ }^{\mathrm{a}}\end{array}$} & Decay Type \\
\hline Beta-gamma emitting radionuclides & $\begin{array}{c}\text { Total of beta-gamma emitting radionuclides shall } \\
\text { not exceed } 4 \text { mrem/yr effective dose equivalent }\end{array}$ & Beta-gamma \\
$\begin{array}{l}\text { Sr-90 and daughters } \\
\text { Tritium }\end{array}$ & $20,000 \mathrm{pCi} / \mathrm{L}$ & Beta \\
I-129 & $1 \mathrm{pCi} / \mathrm{L}$ & Beta \\
Alpha-emitting radionuclides & $15 \mathrm{pCi} / \mathrm{L}$ & Beta-gamma \\
& total alpha emitting radionuclides & Alpha \\
Uranium and daughters & $15 \mathrm{pCi} / \mathrm{L}$ & Alpha \\
$\begin{array}{l}\text { Np-237 and daughters } \\
\text { Plutonium and daughters }\end{array}$ & $15 \mathrm{pCi} / \mathrm{L}$ & Alpha \\
Am-241 and daughters & $15 \mathrm{pCi} / \mathrm{L}$ & Alpha \\
Nonradionuclides & $15 \mathrm{pCi} / \mathrm{L}$ & Alpha \\
Chromium & & Not applicable \\
Mercury & $100 \mu \mathrm{g} / \mathrm{L}$ & Not applicable \\
\hline a. If multiple contaminants are present, use a sum of the fractions to determine the combined COCs remediation goals. & \\
b. Derived concentration if only beta-gamma radionuclide present. & \\
COC contaminant of concern & & \\
SRPA Snake River Plain Aquifer & & \\
\hline
\end{tabular}




\section{REMEDIATION AND DEMOLITION ACTIVITIES}

The VES-SFE-20 tank system remediation was divided into two major components. This phased approach allowed for removal of the tank and waste, while allowing flexibility in coordinating the removal of the vault and associated structures and soils with other related RAs. Phase I and Phase II were completed sequentially. The activities associated with the treatment and disposal of the SFE-20 tank and the waste it contained occurred during the brief intermission period between Phase I and II, with the tank being shipped to Pacific EcoSolutions, Incorporated (Pecos), in Richland, Washington, (Pecos) in May 2006, treated at Pecos by August 2006, and disposed of at the Nevada Test Site (NTS) by January 2007.

\subsection{Phase I: Removal of the Tank and Contents}

Phase I consisted of removing the tank with its contents; removing associated piping and asbestos within the excavation area, tank vault, access tunnel, pump pit, and Building CPP-642; and removing loose surface contamination and any liquid from the vault floor and pump pit. Approximately 1,000 $\mathrm{yd}^{3}$ of soil were removed, stockpiled, and reused for backfill in the course of removing the tank from the vault at a depth of $11 \mathrm{ft}$.

The Phase I activities included:

- Excavation of soil to designated stockpile

- $\quad$ Rerouting of active utilities

- Cutting and capping of abandoned utilities

- Accessing tank vault and applying fixative to tank vault

- $\quad$ Removing tank vault roof

- $\quad$ Removing asbestos-containing material within the vault, tunnel, pump pit, and the CPP-642 building

- $\quad$ Removing the tank (with contents) and placing into transportation vessel and/or transferring to staging area for completion of characterization activities, if necessary

- $\quad$ Removing and characterizing loose surface contamination and liquid in vault and pump pit

- $\quad$ Installing precast, reinforced concrete roof over vault

- $\quad$ Backfilling, compacting, contouring, and grading of remediation area, using stockpiled soils from Phase I excavation, which were later removed as part of the Phase II excavation.

Appendix A provides photographs of the Phase I activities.

\subsection{Phase II: Removal of Remaining Components and Vault}

Phase II RA consisted of removing and disposing of the remaining piping, asbestos-containing material, components, structures, and contaminated soil in the ICDF. Approximately 498 tons of debris were removed and subsequently disposed of at ICDF associated with the unearthing and demolition of the SFE-20 structures, which extended $20 \mathrm{ft}$ below grade.

The Phase II activities included:

- $\quad$ Excavating contaminated soil and disposing at ICDF

- $\quad$ Cutting and capping abandoned utility and process lines at the excavation boundary 
- Removing and disposing of abandoned utility and process lines within the excavation boundary

- Demolishing and removing the concrete structures, including the vault, tunnel, pump pit, pipe corridor, and Building CPP-642, and disposal at ICDF

- Collection of confirmatory samples and subsequent analysis

- Backfilling, compacting, contouring, and grading of remediation area, using locally available, naturally occurring, clean fill material found at the INL Site.

Appendix B provides photographs of the Phase II activities.

\subsection{VES-SFE-20 Tank and Contents Treatment and Disposal}

The tasks associated with the treatment and disposal of the SFE-20 tank and the waste it contained were dictated by the results of the characterization efforts in accordance with the CWP (DOE-ID 2003a). The results of the RCRA hazardous constituents' characterization were captured in the Characterization Summary Report for Operable Unit 3-13, Group 7, VES-SFE-20 Hot Waste Tank System at INTEC (ICP 2005). In addition, results of the radiological sampling and analysis were provided in the U.S. Department of Energy letter to the Agencies with the subject of "Transmittal of the Limitations and Validation Reports for the Characterization of the VES-SFE-20 Hot Waste Tank at the Idaho Nuclear Technology and Engineering Center (FMDP-RFDP-05-083)" (Verwolf 2005). The sampling analysis results identified the presence of TRU constituents $>10 \mathrm{nCi} / \mathrm{g}$, which required off-Site disposal in accordance with the OU 3-13 ROD. Consequently, the tank, contents, shipping container, and associated waste were sent to Pecos for treatment and eventual shipment and disposal at the NTS.

Tank and waste treatment, disposal, and associated activities included:

- $\quad$ Design and loading of a suitable transport container

- $\quad$ Arrangement for transport from INTEC to Richland, Washington (for treatment), to NTS (for disposal)

- Development of transport plans

- $\quad$ Selection of a suitable off-Site waste treatment facility (Pecos)

- $\quad$ Selection of a suitable disposal facility (NTS) (see Appendix C)

- $\quad$ Treatment of the tank and contents (by Pecos in May 2006) for disposal (at NTS in January 2007) (see Appendix D)

- Development and acceptance of associated waste profiles

- $\quad$ Disposal of waste (see Appendix E).

Appendix F provides photographs of the tank and contents treatment activities. The tank and contents ( $\sim 50 \mathrm{gal})$ weighed approximately $1,942 \mathrm{lb}$. The contents were processed through a plasma gasifier at Pecos, and the resulting residue, along with the sectioned tank, gasifier hearth, cooling plate, miscellaneous personal protective equipment, and plastic, were macroencapsulated for disposal. The resulting waste volume of $109 \mathrm{ft}^{3}$ was disposed of at NTS. Prior to disposal, the treated waste was sampled for 1,1,1-trichloroethane and free liquids, which were not detected. 


\subsection{Confirmation Sampling}

The OU 3-13 Group 7 confirmatory sampling plan Field Sampling Plan for the VES-SFE-20 Hot Waste Tank System at INTEC (FSP) (DOE-ID 2003b) was prepared to address criteria for obtaining representative samples, maintain sample integrity, and provide appropriate safety considerations for field personnel. This FSP was implemented with the current revision of the Quality Assurance Project Plan (QAPjP) which provides guidance for sampling, quality assurance, quality control, analytical procedures, and data management (DOE-ID 2002). Together, the QAPjP and FSP constitute the RA sampling and analysis plan.

The FSP established a list of COPCs based upon the data and process knowledge that existed at that time. Those requirements are shown in Table 3-1, which is a reproduction of the Table 6-1 from the FSP. Section 6 of the FSP states: “... the list will be modified based on the results from the tank characterization sampling. For example, COPCs that are nondetectable will be eliminated from further consideration." The results of the tank characterization sampling led to a discussion with the CERCLA Agencies in September 2008. The list of COPCs was reduced at this time where specific contaminants had been found to not be present in the waste. The COPCs removed from Table 3-1 are shown in Table 3-2. Table 3-3 shows the final list of analytes, the specified method, and the detection limits.

Table 3-1. Contaminants of potential concern for VES-SFE-20 tank system. ${ }^{\mathrm{a}}$

\begin{tabular}{|c|c|}
\hline Chemical/Other & Radionuclides $^{\mathrm{b}, \mathrm{c}, \mathrm{d}}$ \\
\hline Universal Treatment Standard (UTS) metals ${ }^{\mathrm{a}, \mathrm{b}, \mathrm{c}}$ & Tritium (H-3) \\
\hline \multirow{4}{*}{$\begin{array}{l}\text { Appendix IX (40 CFR 264) target analyte list (TAL) VOCs } \\
\text { (including acetone, methylene chloride, 1,1,1-trichloroethane, } \\
\text { tetrachloroethene, and trichloroethylene) })^{\mathrm{a}, \mathrm{b}, \mathrm{c}}\end{array}$} & Carbon-14 \\
\hline & Sodium-22 \\
\hline & Potassium-40 \\
\hline & Manganese-54 \\
\hline $\begin{array}{l}\text { Appendix IX (40 CFR 264) TAL semivolatile organic compounds } \\
\text { (SVOCs) }^{\mathrm{a}, \mathrm{b}, \mathrm{c}}\end{array}$ & Cobalt-60 \\
\hline \multirow{2}{*}{$\begin{array}{l}\text { Freon-12 and }-22 \text { (dichlorodifluoromethane and } \\
\text { chlorodifluoromethane) })^{\mathrm{a}}\end{array}$} & Niobium-95 \\
\hline & Zirconium-95 \\
\hline Formaldehyde $\mathrm{a}^{\mathrm{a}, \mathrm{b}}$ & Technetium-99 \\
\hline \multirow{2}{*}{$\mathrm{PCBs}^{\mathrm{a}, \mathrm{b}, \mathrm{c}}$} & Ruthenium-106 \\
\hline & Antimony-125 \\
\hline \multirow{10}{*}{ Asbestos $^{\mathrm{b}}$} & Iodine-129 \\
\hline & Cesium-134, -137 \\
\hline & Cerium-144 \\
\hline & Europium-152, $-154,-155$ \\
\hline & Radium-226 \\
\hline & Uranium-234, $-235^{\mathrm{e}},-238$ \\
\hline & Neptunium -237 \\
\hline & Plutonium-238, $-239,-240,-241,-242$ \\
\hline & Americium-241, -243 \\
\hline & Curium-242, -244 \\
\hline \multicolumn{2}{|c|}{$\begin{array}{l}\text { a. The list of COPCs will be modified based on the data results from the CWP (DOE-ID 2003a). } \\
\text { b. Soil, tank vault, and pump pit. } \\
\text { c. Piping. } \\
\text { d. Absorbed water. } \\
\text { e. U-236 is reported with U-235. }\end{array}$} \\
\hline \multicolumn{2}{|l|}{$\begin{array}{ll}\text { COPC } & \text { contaminant of potential concern } \\
\text { CWP } & \text { Characterization Work Plan } \\
\text { PCB } & \text { polychlorinated biphenyl } \\
\text { VOC } & \text { volatile organic compound } \\
\end{array}$} \\
\hline
\end{tabular}


Table 3-2. Contaminants of potential concern removed from list of contaminants sampled.

\begin{tabular}{ll}
\hline \multicolumn{1}{c}{ Chemical/Other } & \multicolumn{1}{c}{ Radionuclides } \\
\hline $\begin{array}{l}\text { Freon-12 and -22 (dichlorodifluoromethane and } \\
\text { chlorodifluoromethane) }\end{array}$ & Manganese-54 \\
Formaldehyde & Niobium-95 \\
All polychlorinated biphenyls except Aroclor 1260 & Zirconium-95 \\
Asbestos & Ruthenium-106 \\
& Antimony-125 \\
& Iodine-129 \\
& Cesium-134 \\
& Cerium-144 \\
& Europium-155 \\
& Radium-226 \\
& Neptunium-237 \\
& Plutonium-242 \\
& Curium-242 \\
\hline
\end{tabular}

Table 3-3. Final list of contaminants of concern, analytical methods, and detection limits.

\begin{tabular}{|c|c|c|c|}
\hline \multicolumn{2}{|r|}{ Constituent } & Analytical Method & Solids Detection Limits \\
\hline \multicolumn{2}{|c|}{ UTS metals - report as totals and as TCLP } & $\begin{array}{l}\text { EPA Methods } 1311,3010 \mathrm{~A}, 7760 \mathrm{~A}^{\mathrm{a}} \text {, } \\
6010 \mathrm{~B} \text {, and } 7470 \mathrm{~A}\end{array}$ & $\begin{array}{l}0.2-1,000 \mathrm{mg} / \mathrm{kg} \\
\text { depending on metal }\end{array}$ \\
\hline \multicolumn{2}{|c|}{$\begin{array}{l}\text { Appendix IX (40 CFR 264) TAL VOCs, } \\
\text { including acetone and 1,1,1-trichloroethane }\end{array}$} & EPA Method 8260B & $\begin{array}{l}5-100 \mathrm{~g} / \mathrm{kg} \\
\text { depending on VOC }\end{array}$ \\
\hline \multicolumn{2}{|c|}{ Appendix IX (40 CFR 264) TAL SVOCs } & EPA Method 8270C & $\begin{array}{l}660-3,300 \mathrm{~g} / \mathrm{kg} \\
\text { depending on SVOC }\end{array}$ \\
\hline \multicolumn{2}{|c|}{ PCBs-Aroclor-1260 only } & EPA Method 8082 & $350 \mu \mathrm{g} / \mathrm{kg}$ \\
\hline \multicolumn{2}{|c|}{ Tritium } & Liquid scintillation counting (LSC) & $20 \mathrm{pCi} / \mathrm{g}$ \\
\hline \multicolumn{2}{|c|}{ Carbon-14 } & LSC or gas flow proportional (GFP) & $3 \mathrm{pCi} / \mathrm{g}$ \\
\hline \multicolumn{2}{|c|}{ Strontium-90 } & GFP & $0.5 \mathrm{pCi} / \mathrm{g}$ \\
\hline \multicolumn{2}{|c|}{ Technetium-99 } & LSC or GFP & $1 \mathrm{pCi} / \mathrm{g}$ \\
\hline \multicolumn{2}{|c|}{ Uranium isotopes } & Alpha spectroscopy (ALS) & $0.05 \mathrm{pCi} / \mathrm{g}$ \\
\hline \multicolumn{2}{|c|}{$\begin{array}{l}\text { Plutonium isotopes- } \mathrm{Pu}-238, \mathrm{Pu}-239, \mathrm{Pu}-240, \\
\text { and } \mathrm{Pu}-241\end{array}$} & ALS & $0.05 \mathrm{pCi} / \mathrm{g}$ \\
\hline \multicolumn{2}{|c|}{ Plutonium-241 } & LSC & $1 \mathrm{pCi} / \mathrm{g}$ \\
\hline \multicolumn{2}{|c|}{ Americium-241, -243} & ALS & $0.05 \mathrm{pCi} / \mathrm{g}$ \\
\hline \multicolumn{2}{|c|}{ Curium isotopes } & ALS & $0.05 \mathrm{pCi} / \mathrm{g}$ \\
\hline \multicolumn{2}{|c|}{$\begin{array}{l}\text { Gamma emitters including Na-22, K-40, } \\
\text { Co-60, Cs-137, Eu-152, and Eu-154 }\end{array}$} & Gamma spectroscopy (GS) & About $0.1 \mathrm{pCi} / \mathrm{g}$ \\
\hline \multicolumn{4}{|c|}{ a. EPA Method 7760A was not used. } \\
\hline \multicolumn{4}{|c|}{$\begin{array}{ll}\text { EPA } & \text { U.S. Environmental Protection Agency } \\
\text { PCB } & \text { polychlorinated biphenyl } \\
\text { SVOC } & \text { semivolatile organic compound } \\
\text { TAL } & \text { target analyte list } \\
\text { TCLP } & \text { toxicity characteristic leaching procedure } \\
\text { UTS } & \text { Universal Treatment Standard } \\
\text { VOC } & \text { volatile organic compound } \\
\end{array}$} \\
\hline
\end{tabular}


Figure 3-1 shows the location of the 10 random grab samples that were located beneath the SFE-20 structures. Five samples were collected from below the tank vault and five from beneath the pump pit based upon the random grab sample approach as specified in the HWMA/RCRA-approved FSP (DOE-ID 2003b). The OU 3-13 Group 7 RA was designed primarily to address the SFE-20 tank and structures. As these soils beneath the former location of the SFE-20 structures are totally within the OU 3-13 Group 3 Phase II excavation and represent only a minor fraction of that overall excavation, the establishment of institutional controls for the SFE-20 area will be deferred to be addressed during the completion of the OU 3-13 Group 3 Phase II RA Report.

\subsubsection{Confirmatory Sampling Data Summary}

Confirmation samples were collected on November 3, 2008, beneath the former location of the SFE-20 tank vault and pump pit. Five systematic random grab samples were collected from each location and sent to GEL Laboratories, LLC, for analysis. The analyses performed included radionuclides, polychlorinated biphenyls, volatile organic compounds, semivolatile compounds, and metals. Specific analytical results are presented Appendix G. This information was evaluated in accordance with the approved HWMA/RCRA Closure Plan for the VES-SFE-20 tank in the Data Quality Assessment and Data Summary Report for the HWMA/RCRA Closure of the VES-SFE-20 Hot Waste Tank System - Soils. (RPT-622).

Soil samples were collected at a depth of 0 to 6 in. below any soil possibly disturbed during excavation to prevent sampling cross-contaminated soil or introducing outlying data otherwise attributable to experimental error. A basic assumption in the sampling effort was that the samples collected truly were representative of the soil in the immediate area. The statistical pre-calculations leading to the grid size and number of samples specified in the FSP account for an acceptable statistical margin of error (uncertainty) for a random sample location distribution, regardless of symmetry. The analytical methods and calibrations employed similarly preclude errors in individual analyses of sufficient size to warrant their elimination.

The data from the sampling of the soils beneath the SFE-20 tank vault and pump pit were statistically analyzed to determine an exposure point concentration without respect to consideration of outliers or anomalies. The rejection or removal of data points that could be considered outliers or anomalies would only reduce the potential concentrations evaluated with respect to risk, and, therefore, this approach is considered to be conservatively appropriate.

While the mercury data were flagged with an " $R$ " as rejected, these data were still considered appropriate for use in this report. The reason for the " $\mathrm{R}$ " flag was that there was greater than $50 \%$ difference (161\%) between a sample and the lab duplicate sample. Whereas, the $95 \%$ upper confidence limit (UCL) for mercury was more than an order of magnitude lower than the risk-based screening for which these data were still considered acceptable.

There were five volatile organic compounds (1,4-dioxane; acetonitrile; acrolein; isobutylalcohol; and propionitrile) and three semivolatile organic compounds (4-nitroquinoline 1-oxide, aramite, and hexachlorophene) for which the analytes did either not meet initial calibration or continuing calibration criteria, and, thus, the data were "R" flagged. As these particular compounds were all nondetects, this " $R$ " flag does not present any issue in eliminating these compounds from consideration as COPCs.

As a result of the small areal extent of the structures, their proximity to each other, and the expected similarity between the probable sources of contamination, the data from these two subpopulations were combined and analyzed as one data set. A statistical summary was prepared for the compounds that were detected as being present within the samples. It is inappropriate to calculate a 
statistical summary when fewer than five data points have values above the detection limit. In those cases, the maximum reported values were utilized. The remaining analytes (with greater than three values reported above the detection limit) were evaluated using the U.S. Environmental Protection Agency's (EPA's) ProUCL 4.0.2 software available from EPA's website (EPA 2009). For those data sets that contained some reported values below the detection limit, the detection limit was used for calculation of the $95 \%$ UCL, but not for the other statistical properties, such as the mean or median. In order to ensure that the combination of data sets remains conservative, the higher of the maximum or 95\% UCL were used as the exposure point concentration.

The EPA software selected the appropriate distribution as well as recommended the appropriate UCL to use. According to the EPA software, all of the analytes exhibited a normal distribution except for americium-241, cesium-137, plutonium-238, plutonium-239/240, strontium-90, uranium-233/234, lead, and mercury. The Am-241 and mercury data followed a log-normal distribution while cesium-137, plutonium-238, plutonium-239/240, and strontium-90 followed a gamma distribution. The software was unable to discern a viable distribution pattern for either uranium-233/234 or lead. The software recommended UCL is used as the exposure point concentration for the purposes of this report. The printouts from the ProUCL software are attached as Appendix H. Tables 3-4 through 3-8 present the summary data. 


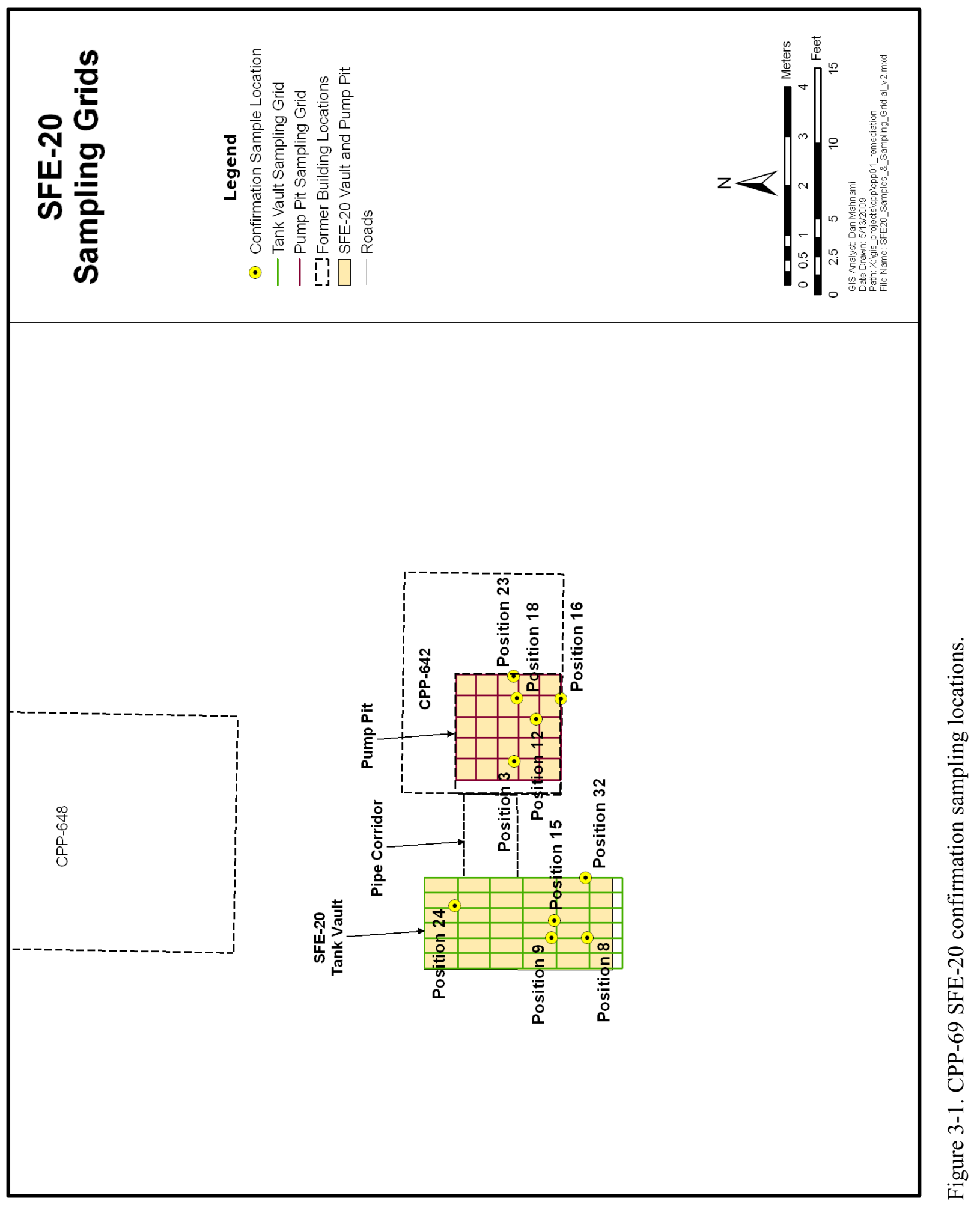


Table 3-4. Radionuclides data summary (pCi/g).

\begin{tabular}{|c|c|c|c|c|c|c|c|c|}
\hline Radionuclides & $\begin{array}{l}\text { Positive } \\
\text { Results }\end{array}$ & Minimum & Maximum & Mean & Median & Std. Dev. & $95 \%$ UCL & EPC \\
\hline Americium-241 & 5 & 0.0327 & 0.242 & 0.077 & 0.038 & 0.092 & $0.144^{\mathrm{a}, \mathrm{b}}$ & 0.242 \\
\hline Cesium-137 & 10 & 8.64 & 5,730 & 1,346 & 412 & 1,956 & $5,175^{\mathrm{c}}$ & 5,730 \\
\hline Cobalt-60 & 3 & 0.12 & 0.719 & $\mathrm{~d}$ & $\mathrm{~d}$ & $\mathrm{~d}$ & $0.719^{\mathrm{e}}$ & 0.719 \\
\hline Europium-152 & 2 & 1.01 & 8.61 & $\mathrm{~d}$ & $\mathrm{~d}$ & $\mathrm{~d}$ & $8.61^{\mathrm{e}}$ & 8.61 \\
\hline Europium-154 & 2 & 0.702 & 5.42 & $\mathrm{~d}$ & $\mathrm{~d}$ & $\mathrm{~d}$ & $5.42^{\mathrm{e}}$ & 5.42 \\
\hline Plutonium-238 & 8 & 0.0452 & 0.716 & 0.175 & 0.088 & 0.225 & $0.318^{\mathrm{b}, \mathrm{c}}$ & 0.716 \\
\hline Plutonium-239/240 & 9 & 0.0333 & 2.42 & 0.506 & 0.178 & 0.763 & $1.127^{\mathrm{b}, \mathrm{c}}$ & 2.42 \\
\hline Plutonium-241 & 1 & $\mathrm{~d}$ & $\mathrm{~d}$ & d & $\mathrm{d}$ & $\mathrm{d}$ & $0.789^{\mathrm{e}}$ & 0.789 \\
\hline Strontium-90 & 10 & 264 & 16,400 & 4,380 & 3,045 & 5,063 & $9,446^{\mathrm{c}}$ & 16,400 \\
\hline Technetium-99 & 1 & $\mathrm{~d}$ & $\mathrm{~d}$ & $\mathrm{~d}$ & $\mathrm{~d}$ & $\mathrm{~d}$ & $1.670^{\mathrm{e}}$ & 1.670 \\
\hline Uranium-233/234 & 10 & 1.05 & 2.21 & 1.377 & 1.215 & 0.436 & $1.630^{\mathrm{f}}$ & 2.21 \\
\hline Uranium-235 & 10 & 0.043 & 0.181 & 0.093 & 0.075 & 0.049 & 0.121 & 0.181 \\
\hline Uranium-238 & 10 & 0.96 & 1.34 & 1.127 & 1.100 & 0.112 & 1.192 & 1.34 \\
\hline Zinc-65 & 1 & $\mathrm{~d}$ & $\mathrm{~d}$ & $\mathrm{~d}$ & $\mathrm{~d}$ & $\mathrm{~d}$ & $0.186^{\mathrm{e}}$ & 0.186 \\
\hline \multicolumn{9}{|c|}{$\begin{array}{l}\text { a. EPA ProUCL software concludes that the data for this analyte follow a log normal distribution. } \\
\text { b. The 95\% UCL was calculated using the limit of detection for samples with nondetected results. } \\
\text { c. EPA ProUCL software concludes that the data for this analyte follow a gamma distribution. } \\
\text { d. Summary statistics inappropriate based upon number of positive results. } \\
\text { e. For samples with four or fewer positive detects, the maximum value was reported. } \\
\text { f. EPA ProUCL software concludes that the data do not follow a discernible distribution and recommends use of students-t approach. }\end{array}$} \\
\hline \multicolumn{9}{|c|}{$\begin{array}{ll}\text { EPA } & \text { U.S. Environmental Protection Agency } \\
\text { EPC } & \text { exposure point concentration } \\
\text { UCL } & \text { upper confidence limit }\end{array}$} \\
\hline
\end{tabular}

Table 3-5. Polychlorinated biphenyl data summary $(\mu \mathrm{g} / \mathrm{kg})$.

\begin{tabular}{lcc}
\hline $\begin{array}{c}\text { Polychlorinated } \\
\text { Biphenyl }\end{array}$ & Positive Results & $\begin{array}{c}\text { Maximum Value } \\
\text { (also EPC) }\end{array}$ \\
\hline Aroclor 1254 & 2 & 8.3 \\
Aroclor 1260 & 1 & 4.4 \\
\hline EPC exposure point concentration & \\
\hline
\end{tabular}

Table 3-6. Volatile organic compounds data summary ( $\mu \mathrm{g} / \mathrm{kg})$.

\begin{tabular}{lcccccccc}
\hline \multicolumn{1}{c}{$\begin{array}{l}\text { Volatile Organic } \\
\text { Compounds }\end{array}$} & $\begin{array}{c}\text { Positive } \\
\text { Results }\end{array}$ & Minimum & Maximum & Mean & Median & Std. Dev. & 95\% UCL & EPC \\
\hline Acetone & 3 & 1.83 & 3.55 & $\mathrm{a}$ & $\mathrm{a}$ & $\mathrm{a}$ & $3.55^{\mathrm{b}}$ & 3.55 \\
Chloroform & 9 & 0.469 & 4.12 & 1.882 & 1.720 & 1.353 & $2.555^{\mathrm{c}}$ & 4.12 \\
Methylene chloride & 2 & 2.8 & 2.87 & $\mathrm{a}$ & $\mathrm{a}$ & $\mathrm{a}$ & $2.87^{\mathrm{b}}$ & 2.87 \\
Tetrachloroethylene & 3 & 0.376 & 0.435 & $\mathrm{a}$ & $\mathrm{a}$ & $\mathrm{a}$ & $0.435^{\mathrm{b}}$ & 0.435 \\
Toluene & 1 & $\mathrm{a}$ & $\mathrm{a}$ & $\mathrm{a}$ & $\mathrm{a}$ & $\mathrm{a}$ & $0.333^{\mathrm{b}}$ & 0.333 \\
Xylene (Total) & 1 & $\mathrm{a}$ & $\mathrm{a}$ & $\mathrm{a}$ & $\mathrm{a}$ & $\mathrm{a}$ & $0.519^{\mathrm{b}}$ & 0.519 \\
\hline \\
$\begin{array}{l}\text { a. Summary statistics inappropriate based upon number of positive results. } \\
\text { b. For samples with four or fewer positive detects, the maximum value was reported. }\end{array}$ \\
c. The 95\% UCL was calculated using the limit of detection for samples with nondetected results. \\
EPC exposure point concentration \\
UCL upper confidence limit \\
UCL
\end{tabular}


Table 3-7. Semivolatile organic compounds data summary $(\mu \mathrm{g} / \mathrm{kg})$.

\begin{tabular}{ccccc}
\hline $\begin{array}{c}\text { Semivolatile Organic } \\
\text { Compounds }\end{array}$ & $\begin{array}{c}\text { Positive } \\
\text { Results }\end{array}$ & Minimum & Maximum & $\begin{array}{c}\text { Exposure Point } \\
\text { Concentration }\end{array}$ \\
\hline Di-n-butyl phthalate & 3 & 77.8 & 282 & 282 \\
\hline
\end{tabular}

Table 3-8. Inorganic compounds data summary (mg/kg).

\begin{tabular}{|c|c|c|c|c|c|c|c|c|}
\hline Inorganic Compounds & Results & Minimum & Maximum & Mean & Median & Std. Dev. & $95 \%$ UCL & EPC \\
\hline Antimony & 10 & 0.99 & 1.9 & 1.50 & 1.45 & 0.30 & 1.67 & 1.9 \\
\hline Arsenic & 10 & 3.7 & 7.7 & 5.44 & 5.70 & 1.19 & 6.13 & 7.7 \\
\hline Barium & 10 & 88.8 & 183 & 119 & 111 & 28.01 & 136 & 183 \\
\hline Beryllium & 10 & 0.3 & 0.45 & 0.39 & 0.41 & 0.05 & 0.42 & 0.45 \\
\hline Cadmium & 10 & 0.23 & 0.53 & 0.38 & 0.39 & 0.10 & 0.44 & 0.53 \\
\hline Chromium & 10 & 12.5 & 20.6 & 17.0 & 16.9 & 2.79 & 18.7 & 20.6 \\
\hline Lead & 10 & 6.8 & 22 & 10.9 & 8.95 & 5.01 & $13.8^{\mathrm{a}}$ & 22 \\
\hline Mercury $^{\mathrm{b}}$ & $10^{\mathrm{b}}$ & $0.011^{\mathrm{b}}$ & $0.52^{\mathrm{b}}$ & $0.09^{\mathrm{b}}$ & $0.03^{b}$ & $0.16^{\mathrm{b}}$ & $0.21^{\mathrm{b}, \mathrm{c}}$ & 0.52 \\
\hline Nickel & 10 & 13.8 & 20.6 & 16.4 & 15.9 & 1.96 & 17.6 & 20.6 \\
\hline Selenium & 2 & 0.55 & 0.58 & $\mathrm{~d}$ & $\mathrm{~d}$ & $\mathrm{~d}$ & $0.55^{\mathrm{e}}$ & 0.58 \\
\hline Silver & 10 & 0.12 & 0.53 & 0.37 & 0.38 & 0.11 & 0.43 & 0.53 \\
\hline Thallium & 10 & 0.12 & 0.19 & 0.15 & 0.14 & 0.02 & 0.16 & 0.19 \\
\hline Vanadium & 10 & 20.2 & 33.3 & 26.1 & 26.7 & 4.07 & 28.4 & 33.3 \\
\hline Zinc & 10 & 32.2 & 72.1 & 50.2 & 47.2 & 11.5 & 56.8 & 72.1 \\
\hline \multicolumn{9}{|c|}{$\begin{array}{l}\text { a. EPA ProUCL software concludes that the data does not follow a discernible distribution and recommends use of students-t approach. } \\
\text { b. The mercury results were R-flagged as a result of a high relative percent difference. However the data are still usable for the purposes of a risk } \\
\text { assessment as they are far below the level of significance. } \\
\text { c. EPA ProUCL software concludes that the data for this analyte follows a log normal distribution. } \\
\text { d. Summary statistics inappropriate based upon number of positive results. } \\
\text { e. For samples with four or fewer positive detects, the maximum value was reported. }\end{array}$} \\
\hline \multicolumn{9}{|c|}{$\begin{array}{ll}\text { EPA } & \text { U.S. Environmental Protection Agency } \\
\text { EPC } & \text { exposure point concentration } \\
\text { UCL } & \text { upper confidence limit } \\
\end{array}$} \\
\hline
\end{tabular}




$$
\text { 3-10 }
$$




\section{CPP-69 CHRONOLOGY OF EVENTS}

Table 4-1 presents a chronology of events for the CPP-69 project.

Table 4-1. Chronology of events for the CPP-69 project.

\begin{tabular}{|c|c|c|}
\hline & Date & Event \\
\hline \multicolumn{2}{|c|}{ October 1999} & Signed final ROD for INTEC (DOE-ID 1999) \\
\hline \multicolumn{2}{|c|}{ May 2002} & Approved HMWA/RCRA Closure Plan \\
\hline \multicolumn{2}{|c|}{ January 2003} & Approved Characterization Work Plan \\
\hline \multicolumn{2}{|c|}{ January 2003} & Attempted remote sampling effort \\
\hline \multicolumn{2}{|c|}{ February 2003} & Manned entry into the vault for sampling and survey \\
\hline \multicolumn{2}{|c|}{ June 2003} & Finalized and transmitted RD/RA Work Plan (DOE-ID 2008) \\
\hline \multicolumn{2}{|c|}{ November 2004} & Initiated Phase I activities \\
\hline \multicolumn{2}{|c|}{ April 2005} & Completed Phase I tank removal and sampling \\
\hline \multicolumn{2}{|c|}{ December 2005} & Completed Phase I field activities \\
\hline \multicolumn{2}{|c|}{ February 2006} & Performed Phase 1 Prefinal Inspection \\
\hline \multicolumn{2}{|c|}{ February 2006} & Transmitted Phase I Prefinal Inspection Report (Butler 2006) \\
\hline \multicolumn{2}{|c|}{ May 2006} & Tank and waste shipped to Pecos in Washington \\
\hline \multicolumn{2}{|c|}{ August 2006} & Tank and waste treatment completed by Pecos \\
\hline \multicolumn{2}{|c|}{ January 2007} & SFE-20 tank and treated waste disposed of at NTS \\
\hline \multicolumn{2}{|c|}{ June 2008} & Initiated Phase II activities \\
\hline \multicolumn{2}{|c|}{ September 2008} & Completed Phase II excavation \\
\hline \multicolumn{2}{|c|}{ October 2008} & Completed vault, tunnel, and pit disposal to ICDF \\
\hline \multicolumn{2}{|c|}{ November 2008} & Performed confirmation sampling \\
\hline \multicolumn{2}{|c|}{ December 2008} & Demobilized equipment from the Phase II site \\
\hline \multicolumn{2}{|c|}{ December 2008} & Performed Phase II Prefinal Inspection \\
\hline \multicolumn{2}{|c|}{ January 2009} & Transmitted Prefinal/Final Inspection Report (Dieter 2009) \\
\hline $\begin{array}{l}\text { HWMA } \\
\text { ICDF } \\
\text { INTEC } \\
\text { NTS } \\
\text { Pecos } \\
\text { RA } \\
\text { RCRA } \\
\text { RD } \\
\text { ROD }\end{array}$ & $\begin{array}{l}\text { Hazardo } \\
\text { Idaho } \mathrm{Cl} \\
\text { Idaho N } \\
\text { Nevada } \\
\text { Pacific } \mathrm{F} \\
\text { remedial } \\
\text { Resourc } \\
\text { remedial } \\
\text { record o }\end{array}$ & $\begin{array}{l}\text { Act } \\
\text { ity } \\
\text { Engineering Center } \\
\text { ted } \\
\text { covery Act }\end{array}$ \\
\hline
\end{tabular}


4-2 


\section{PERFORMANCE STANDARDS AND CONSTRUCTION QUALITY CONTROL}

The OU 3-13 CPP-69 FSP was developed to guide sampling for the site (DOE-ID 2003b). The FSP was implemented with the current revision of the Quality Assurance Project Plan for Waste Area Groups 1, 2, 3, 4, 5, 6, 7, 10 and Inactive Sites (DOE-ID 2002), which provides guidance for sampling, quality assurance, quality control, analytical procedures, and data management. Together, the QAPjP (DOE-ID 2002) and the FSP constitute the RA sampling and analysis plan. There were no deviations from the QAPjP or FSP.

The QAPjP and FSP were prepared in accordance with "Guidance for Conducting Remedial Investigations and Feasibility Studies Under CERCLA" (EPA 1988), the FFA/CO, and Idaho Cleanup Project policies and procedures.

\subsection{Performance Comparison with Remedial Action Objectives and Remediation Goals}

Section 3.1 of the OU 3-13 Group 7 RD/RA WP identified the primary purpose of confirmation sampling as "Sampling and assessing soil beneath the tank system to ensure that contaminant levels do not pose an external exposure risk or threat to groundwater" (DOE-ID 2008). The FSP Problem Statement 1 stated that collecting verification data was necessary to determine if contamination remaining at the site will pose an unacceptable risk in comparison to the OU 3-13 remediation goals and RAOs.

\subsubsection{External Exposure Risk}

External exposure risk was addressed in the OU 3-13 ROD through the establishment of remediation goals that were identified in Table 8-1 of the ROD (DOE-ID 1999). The accepted scenario for these soil risk-based remediation goals was based upon workers and future residents reasonably coming in contact with contaminated soil within $10 \mathrm{ft}$ of the surface. As the bottom of the soil excavation surrounding and below the SFE-20 structures was more than $20 \mathrm{ft}$ below surrounding grade and the excavation was filled with clean fill material, there is no reasonable pathway for workers or future residents to become exposed to the remaining contamination; therefore, the remediation goals were met. Nevertheless, it would be inappropriate to release the site for unrestricted use due to the contamination left at greater than $20 \mathrm{ft}$ below surrounding grade. The data in Table 5-1 show that the soil at the bottom of the excavation, if brought to the surface through some future activity, could present an unacceptable risk. Therefore, these soils will require the implementation of institutional controls consisting primarily of deed restrictions and drilling/excavation controls. However, as the surface area beneath the former location of the SFE-20 structures represents less than $1 \%$ of the overall surface area of the surrounding excavation, institutional controls should be based upon the larger excavation rather than create a patchwork of different institutional controls for one area of contamination. The OU 3-13 Group 3 Phase II RA Report that addresses the larger excavation will be used to determine the appropriate level and length of institutional controls. 
Table 5-1. Comparison of contaminant concentrations with external risk remediation goals.

\begin{tabular}{|c|c|c|c|c|}
\hline Contaminant of Concern & EPC & Units & $\begin{array}{l}\text { Soil Risk-Based } \\
\text { Remediation Goal } \\
(0-10 \mathrm{ft} \text { bgs })\end{array}$ & $\begin{array}{c}\text { Remediation } \\
\text { Goal Met? }\end{array}$ \\
\hline \multicolumn{5}{|l|}{ Radionuclides } \\
\hline Americium-241 & 0.242 & $\mathrm{pCi} / \mathrm{g}$ & 290 & Yes \\
\hline Cesium-137 & 5,730 & $\mathrm{pCi} / \mathrm{g}$ & 23 & $\mathrm{Yes}^{\mathrm{a}}$ \\
\hline Europium-152 & 8.61 & $\mathrm{pCi} / \mathrm{g}$ & 270 & Yes \\
\hline Europium-154 & 5.42 & $\mathrm{pCi} / \mathrm{g}$ & 5,200 & Yes \\
\hline Plutonium-238 & 0.716 & $\mathrm{pCi} / \mathrm{g}$ & 670 & Yes \\
\hline Plutonium-239/240 & 2.42 & $\mathrm{pCi} / \mathrm{g}$ & 250 & Yes \\
\hline Plutonium-241 & 0.789 & $\mathrm{pCi} / \mathrm{g}$ & 56,000 & Yes \\
\hline Strontium-90 & 16,400 & $\mathrm{pCi} / \mathrm{g}$ & 223 & $\mathrm{Yes}^{\mathrm{a}}$ \\
\hline \multicolumn{5}{|l|}{ Nonradionuclides } \\
\hline Mercury & 0.52 & $\mathrm{mg} / \mathrm{kg}$ & 23 & Yes \\
\hline \multicolumn{5}{|c|}{$\begin{array}{l}\text { a. The concentrations of Cs-137 and Sr-90 would have exceeded the soil risk-based remediation goals if they were less than } 10 \mathrm{ft} \text {. below the } \\
\text { surface. Since these soils are significantly below this level, those risk-based remediation goals were met. }\end{array}$} \\
\hline $\begin{array}{ll}\text { bgs } & \text { below ground surface } \\
\text { EPC } & \text { exposure point concer }\end{array}$ & & & & \\
\hline
\end{tabular}

\subsubsection{Threat to Groundwater}

The threat to groundwater posed by the contaminants found in the confirmation sampling was first compared with the background concentration of those contaminants found in the INL soils (Rood, Harris, and White 1995) with the exception for arsenic where it has been widely recognized that the published background for arsenic was not representative of most INL soils. EDF-6655, "Supporting Risk Evaluations for WAG 3 Group 3, Phase II RD/RA Work Plan," provides further explanation of this situation and lists the average background concentration of arsenic in INTEC soils at $8.2 \mathrm{mg} / \mathrm{kg}$.

These comparisons are presented in Tables 5-2 and 5-3. None of the organic constituents have background levels. Those contaminants that exceed the background concentrations or where background levels have not been established were further screened against risk-based screening levels.

All of the inorganic contaminants in the soils below the SFE-20 Hot Waste Tank System that exceeded INL background levels were less than EPA Region IX soil screening levels (SSLs) for groundwater with a dilution attenuation factor of 20 (EPA 2008). Table 5-4 presents this comparison.

The organics found in the soils beneath the SFE-20 Hot Waste Tank System were evaluated against the EPA Region IX SSLs for threat to groundwater with a dilution attenuation factor of 20 (EPA 2008). The cancer risk-based screening levels were multiplied by $1 \mathrm{E}+2$ to reflect $1 \mathrm{E}-4$ risk level utilized under the FFA/CO. None of the organic constituents exceeded the risk-based screening levels. This comparison is presented Table 5-5.

Similarly, the remaining radionuclides above INL soil background levels or where background levels had not been established were compared to the SSLs for radionuclides (see Table 5-6). Cs-137 and Sr-90 exceed the SSL. No SSL has been established for Eu-152 or Eu-154. All four of these constituents have relatively short half-lives (see Table 5-7). These contaminants were evaluated for their potential to pose a threat to the groundwater. Their short half-lives in combination with the time needed for the contaminant to travel through the unsaturated vadose zone allows the isotope to decay away. The OU 3-13 Remedial Investigation/Baseline Risk Assessment evaluated the travel time to the aquifer for these isotopes based 
Table 5-2. Comparison of inorganic constituents to INL Site soil background levels.

\begin{tabular}{lccc}
\hline & $\begin{array}{c}\text { EPC } \\
(\mathrm{mg} / \mathrm{kg})\end{array}$ & $\begin{array}{c}\text { INL Site Background } \\
(\mathrm{mg} / \mathrm{kg})\end{array}$ & Less Than Background? \\
\hline Antimony & 1.9 & 7.4 & Yes \\
Arsenic & 7.7 & $8.2^{\mathrm{a}}$ & Yes \\
Barium & 183 & 440 & Yes \\
Beryllium & 0.45 & 3.0 & Yes \\
Cadmium & 0.53 & 3.7 & Yes \\
Chromium & 20.6 & 50 & Yes \\
Lead & 22 & 23 & Yes \\
Mercury & 0.52 & 0.074 & No \\
Nickel & 20.6 & 55 & Yes \\
Selenium & 0.58 & 0.34 & No \\
Silver & 0.53 & ND & No \\
Thallium & 0.19 & 0.68 & Yes \\
Vanadium & 33.3 & 70 & Yes \\
Zinc & 72.1 & 220 & Yes \\
\hline a. Arsenic background concentration established by EDF-6655 rather than Rood, Harris, and White (1995). & \\
EPC exposure point concentration & & & \\
INL Idaho National Laboratory & & & \\
ND not detected & &
\end{tabular}

Table 5-3. Comparison of radionuclides to INL Site soil background levels.

\begin{tabular}{|c|c|c|c|}
\hline & $\begin{array}{c}\mathrm{EPC} \\
(\mathrm{pCi} / \mathrm{g})\end{array}$ & $\begin{array}{l}\text { INL Site Background } \\
(\mathrm{pCi} / \mathrm{g})\end{array}$ & Less Than Background? \\
\hline Americium-241 & 0.242 & 0.019 & No \\
\hline Cesium-137 & 5,730 & 1.28 & No \\
\hline Cobalt-60 & 0.719 & NA & No \\
\hline Europium-152 & 8.610 & NA & No \\
\hline Europium-154 & 5.420 & NA & No \\
\hline Plutonium-238 & 0.716 & 0.0091 & No \\
\hline Plutonium-239/240 & 2.42 & 0.19 & No \\
\hline Plutonium-241 & 0.789 & NA & No \\
\hline Strontium-90 & 16,400 & 0.76 & No \\
\hline Technetium-99 & 1.670 & NA & No \\
\hline Uranium-233/234 & 2.21 & 1.95 & Yes \\
\hline Uranium-235 & 0.181 & NA & No \\
\hline Uranium-238 & 1.34 & 1.85 & Yes \\
\hline Zinc-65 & 0.186 & NA & No \\
\hline $\begin{array}{ll}\text { EPC } & \text { exposure point } ~ \\
\text { INL } & \text { Idaho National I } \\
\text { NA } & \text { no soil backgrou }\end{array}$ & & & \\
\hline
\end{tabular}


Table 5-4. Inorganic contaminant concentrations compared to screening levels.

\begin{tabular}{lccc}
\hline & $\begin{array}{c}\text { EPC } \\
(\mathrm{mg} / \mathrm{kg})\end{array}$ & $\begin{array}{c}\text { Risk-Based Screening Level }{ }^{\mathrm{a}} \\
(\mathrm{mg} / \mathrm{kg})\end{array}$ & $\begin{array}{c}\text { Less Than Screening } \\
\text { Level? }\end{array}$ \\
\hline Mercury & 0.52 & 11.4 & Yes \\
Selenium & 0.58 & 19 & Yes \\
Silver & 0.53 & 32 & Yes \\
\hline a. Risk based screening level from EPA Region IX SSLs with a DAF = 20 (EPA 2008). & \\
DAF dilution attenuation factor & & \\
EPA U.S. Environmental Protection Agency & & \\
EPC exposure point concentration & & \\
SSL soil screening level & & \\
\hline
\end{tabular}

Table 5-5. Organic contaminant concentrations compared to screening levels.

\begin{tabular}{|c|c|c|c|c|}
\hline & $\begin{array}{c}\text { EPC } \\
\text { (ug/kg) }\end{array}$ & $\begin{array}{l}\text { Noncancer Risk-Based } \\
\text { Screening Level }{ }^{\mathrm{a}} \\
(\mathrm{ug} / \mathrm{kg})\end{array}$ & $\begin{array}{l}\text { Cancer Risk-Based } \\
\text { Screening Level }{ }^{\mathrm{b}} \\
\quad(\mathrm{ug} / \mathrm{kg})\end{array}$ & $\begin{array}{l}\text { Less than } \\
\text { Risk-Based } \\
\text { Screening } \\
\text { Level? }\end{array}$ \\
\hline Aroclor 1254 & 8.3 & Not applicable & 10,200 & Yes \\
\hline Aroclor 1260 & 4.4 & Not applicable & 28,000 & Yes \\
\hline Acetone & 3.55 & 88,000 & Not applicable & Yes \\
\hline Chloroform & 4.12 & Not applicable & 110 & Yes \\
\hline Methylene chloride & 2.87 & Not applicable & 2,400 & Yes \\
\hline Tetrachloroethylene & 0.435 & Not applicable & 100 & Yes \\
\hline Toluene & 0.333 & 34,000 & Not applicable & Yes \\
\hline Xylene (total) & 0.519 & 4,600 & Not applicable & Yes \\
\hline Di-n-butyl phthalate & 282 & 220,000 & Not applicable & Yes \\
\hline \multicolumn{5}{|c|}{$\begin{array}{l}\text { a. Risk-based screening level from EPA Region IX SSLs with a DAF = } 20 \text { (EPA 2008). } \\
\text { b. Cancer risk-based screening level from EPA Region IX SSLs with a DAF = } 20 \text { and 1E-4 risk level (EPA 2008). }\end{array}$} \\
\hline \multicolumn{5}{|c|}{$\begin{array}{ll}\text { DAF } & \text { dilution attenuation factor } \\
\text { EPA } & \text { U.S. Environmental Protection Agency } \\
\text { EPC } & \text { exposure point concentration } \\
\text { SSL } & \text { soil screening level }\end{array}$} \\
\hline
\end{tabular}

Table 5-6. Comparison of radionuclide concentrations to EPA Region IX SSLs.

\begin{tabular}{lccc}
\hline & $\begin{array}{c}\text { EPC } \\
(\mathrm{pCi} / \mathrm{g})\end{array}$ & $\begin{array}{c}\text { Risk-Based Screening Level } \\
(\mathrm{pCi} / \mathrm{g})\end{array}$ & $\begin{array}{c}\text { Less }^{\mathrm{a}} \text { than } \\
\text { SSL? }\end{array}$ \\
\hline Americium-241 & 0.242 & 258 & Yes \\
Cesium-137 & 5,730 & 5,610 & No \\
Cobalt-60 & 0.719 & 241 & Yes \\
Europium-152 & 8.610 & No SSL & No SSL \\
Europium-154 & 5.420 & No SSL & No SSL \\
Plutonium-238 & 0.716 & 175 & Yes \\
Plutonium-239/240 & 2.42 & 156 & Yes \\
Plutonium-241 & 0.789 & 1,000 & Yes \\
Strontium-90 & 16,400 & 26.9 & No \\
Technetium-99 & 1.670 & 373 & Yes \\
Uranium-235 & 0.181 & 77.7 & Yes \\
Zinc-65 & 0.186 & 5,600 & Yes \\
a. Risk-based screening level from EPA with a DAF $=20$ and 1E-4 risk level (EPA 2007). & \\
DAF dilution attenuation factor & & \\
EPA U.S. Environmental Protection Agency & & \\
EPC exposure point concentration & &
\end{tabular}


Table 5-7. Half-lives of remaining radionuclides.

\begin{tabular}{ll}
\hline & Half-Life \\
\hline Cesium-137 & 30.1 years \\
Europium-152 & 13.5 years \\
Europium-154 & 8.59 years \\
Strontium-90 & 28.8 years \\
\hline
\end{tabular}

upon their $\mathrm{K}_{\mathrm{d}}$ in contrast to their half-lives (DOE-ID 1997). As explained in that document in Appendix F, Section 5.1.2.2, if that travel time exceeds 10 half-lives (i.e., a 99.9\% reduction), then that isotope is not considered to be a threat. Appendix F, Table 5.12, of that document is summarized in Table 5-8, eliminating Cs-137, Eu-152, and Eu-154 as contaminants of concern. This leaves Sr-90 for consideration.

Since the finalization of the OU 3-13 ROD, the OU 3-14 ROD (DOE-ID 2007) and the supporting Remedial Investigation/Baseline Risk Assessment (DOE-ID 2006a), have, through extensive modeling of the alluvium and groundwater, concluded that Group 3 soils (which surround the soils beneath the SFE-20 structures) do not pose an unacceptable risk to groundwater (see Section 2.1 of the OU 3-13 Group 3 Phase II RD/RA WP (DOE-ID 2006b). This modeling used source terms in excess of those found beneath the SFE-20 Hot Waste Tank System for Sr-90 (32,600 pCi/g) and concluded there was not a threat to groundwater (Table 5-9). As such, the contaminants in the soils beneath the SFE-20 Hot Waste Tank System also do not pose a threat to groundwater.

An evaluation of the SFE-20 tank and structures upon removal revealed the system to essentially be intact. The majority of the contamination in the area soils does not appear to have been a result of releases from the SFE-20 system, but, rather, from the CPP-01S injection well and other sources that are being addressed as part of OU 3-13 Group 3 Phase II remediation. Therefore, as noted above, contamination remaining in the soils beneath the SFE-20 structures should not be addressed in isolation for the purposes of institutional control, but, instead, should be addressed as part of the larger excavation of soils adjacent to the CPP-603 facility.

Table 5-8. Estimated travel time through sediments versus half-life.

\begin{tabular}{lcccccc}
\hline & $\begin{array}{c}\mathrm{K}_{\mathrm{d}} \\
\left(\mathrm{cm}^{3} / \mathrm{g}\right)\end{array}$ & $\begin{array}{c}\text { Half-Life } \\
\text { (years) }\end{array}$ & Retardation & $\begin{array}{c}\text { Travel Time } \\
\text { (years) }\end{array}$ & $\begin{array}{c}\text { Number of Half- } \\
\text { Lives in Sediment }\end{array}$ & $\begin{array}{c}\text { Half-Lives in } \\
\text { Sediment } \\
>10 ?\end{array}$ \\
\hline Cs-137 & $5.00 \mathrm{E} 2$ & $3.02 \mathrm{E} 1$ & $2.50 \mathrm{E} 3$ & $1.4 \mathrm{E} 3$ & 47.2 & Yes \\
$\mathrm{Eu}-152$ & $3.40 \mathrm{E} 2$ & $1.36 \mathrm{E} 1$ & $1.70 \mathrm{E} 3$ & $9.7 \mathrm{E} 2$ & 71.3 & Yes \\
$\mathrm{Eu}-154$ & $3.40 \mathrm{E} 2$ & $8.80 \mathrm{E} 0$ & $1.70 \mathrm{E} 3$ & $9.7 \mathrm{E} 2$ & 110.2 & Yes \\
Sr-90 & $1.20 \mathrm{E} 1$ & $2.91 \mathrm{E} 1$ & $6.10 \mathrm{E} 1$ & $3.5 \mathrm{E} 1$ & 1.2 & No \\
\hline
\end{tabular}

Table 5-9. Comparison of Sr-90 concentration with OU 3-14 modeled concentration.

\begin{tabular}{lccc}
\hline SFE-20 Soils Concentration & $\begin{array}{c}\text { OU 3-14 RI/BRA } \\
(\mathrm{pCi} / \mathrm{g})\end{array}$ & $\begin{array}{c}\text { (DOE-ID 2006a) } \\
\text { Modeled Soils } \\
(\mathrm{pCi} / \mathrm{g})\end{array}$ & $\begin{array}{c}\text { Less than OU 3-14 Modeled } \\
\text { Concentration? }\end{array}$ \\
\hline Strontium-90 & 16,400 & 32,600 & Yes \\
\hline $\begin{array}{l}\text { BRA } \quad \begin{array}{l}\text { baseline risk assessment } \\
\text { OU }\end{array} \\
\text { RI } \quad \text { remede unit } \\
\text { remedial investigation }\end{array}$ & & \\
\hline
\end{tabular}




\section{CPP-69 FINAL INSPECTION AND CERTIFICATION}

There were two prefinal inspections, one for each phase of the RA for the SFE-20 system removal. The Phase I Prefinal Inspection Report (Butler 2006) was sent to the Agencies on February 16, 2006, and there were no comments concerning the report. The Phase II CPP-69 Prefinal/Final Inspection Report (Dieter 2009) was sent to the Agencies on January 23, 2009. The report noted no deficiencies on the prefinal inspection checklist and there were no subsequent comments from the Agencies. Since there were no outstanding construction items related to the Phase II prefinal inspection, it constituted the final inspection for Site CPP-69.

Although the CERCLA remediation of the VES-SFE-20 tank system was planned in a manner to meet the CERCLA objectives, and also satisfy the additional requirements imposed by the HWMA/RCRA Closure Plan, a separate closure certification will be submitted to the Department of Environmental Quality (Idaho) in accordance with RCRA requirements. 
6-2 


\section{OPERATIONS AND SITE MAINTENANCE}

As noted earlier in Section 5, it would be inappropriate to establish institutional controls solely for the soils beneath the former location of the SFE-20 tank and structures. These soils represent a small fraction of a much larger excavation and are surrounded by soils contaminated by other sources. As such, the establishment of institutional controls should be handed off to the Remedial Action Report for the larger OU 3-13 Group 3 Phase II soils project.

This was anticipated by the OU 3-13 ROD in Table 11-1 where institutional controls are required prior to removal of the SFE-20 system, but there is no mention of potential institutional controls after remediation. In contrast, Table 11-1 specifically identifies potential institutional controls that will be necessary for the Group 3 soils that surround the SFE-20 location after their remediation.

Gamma surveys of the soils greater than $10 \mathrm{ft}$ below grade for both the soils beneath the SFE-20 system and the surrounding soils indicate that contamination levels in this general area are relatively consistent in showing both Cs-137 and Sr-90 are above the remediation goals if the soils were near the ground surface. Therefore, grouping the SFE-20 soils with the surrounding Group 3 soils will result in institutional controls sufficient to alert future users of the land that contaminated soils were left in place at depths below $10 \mathrm{ft}$. These controls will be determined and formalized in the OU 3-13 Group 3 Phase II RA Report. This site will not require any specific operation and maintenance activities, e.g., radiological monitoring, erosion, animal intrusion, or vegetative growth inspection. 


\section{SUMMARY OF PROJECT COSTS}

Table 8-1 provides a summary of costs for the RA at CPP-69 and a comparison to the original ROD estimate. As reported in the ROD, all costs associated with this remediation are considered capital costs. Total actual costs for CPP- 69 were $21 \%$ less than the estimate in the ROD when adjusted for inflation.

Table 8-1. Cost summary of remedial actions for CERCLA Group 7 Site CPP-69.

\begin{tabular}{|c|c|c|c|}
\hline & Cost Elements ${ }^{\mathrm{a}}$ & $\begin{array}{l}\text { ROD Estimate } \\
(1997 \text { \$ Value })^{\mathrm{b}}\end{array}$ & $\begin{array}{c}\text { Actual Costs } \\
(1997 \$ \text { Value })^{\mathrm{c}}\end{array}$ \\
\hline $\mathrm{FFA} / \mathrm{CO}$ & anagement and Oversight & $\$ 862,000$ & $\$ 255,000$ \\
\hline Remedia & esign & $\$ 893,000$ & $\$ 700,000$ \\
\hline Remedia & ction Construction & $\$ 3,008,000$ & $\$ 2,814,000$ \\
\hline Total & & $\$ 4,763,000$ & $\$ 3,768,000$ \\
\hline $\begin{array}{l}\text { Differen } \\
\text { and the } t\end{array}$ & $\begin{array}{l}\text { between total actual cost } \\
1 \text { ROD estimate }\end{array}$ & & \\
\hline \multicolumn{4}{|c|}{$\begin{array}{l}\text { a. Cost elements are listed as identified under "Capital Costs" in Table 11-7 of the ROD. All costs are considered capital costs as estimated in } \\
\text { the ROD. } \\
\text { b. Each estimate was adjusted to } 1997 \text { net present value. } \\
\text { c. Reported costs are actual values through January } 2009 \text { de-escalated to } 1997 \text { dollars. }\end{array}$} \\
\hline $\begin{array}{l}\text { CERCLA } \\
\text { FFA/CO } \\
\text { ROD }\end{array}$ & $\begin{array}{l}\text { Comprehensive Environmental R } \\
\text { Federal Facility Agreement and } \mathrm{C} \\
\text { record of decision }\end{array}$ & $\begin{array}{l}\text { Isation, and Liability } \\
\text { OE-ID 1991) }\end{array}$ & \\
\hline
\end{tabular}




\section{LESSONS LEARNED}

The remediation of the SFE-20 Hot Waste Tank System spanned 6 years and was a complex project requiring significant design and multiphased activities to perform. The remediation included initial characterization, tank extraction and sampling, off-Site treatment and disposal, utility removal and rerouting, contaminated soils excavation and disposal, and contaminated systems removal, dismantlement, and disposal. Schedules required work to be performed not only in the summer months but also through the winter of 2003/2004 and 2004/2005. During the various evolutions performed by the project team, several lessons were learned that either added to the experience and ability of the crew or caused improved preparations for future work.

Below are specific examples of lessons learned during the course of the SFE-20 project:

- $\quad$ The systems associated with the SFE-20 Hot Waste Tank were some of the original plant installations dating back to the 1950 s. Over the course of time, many modifications were made to that part of the plant and associated waste processes, which included old process system abandonments, installation of new utilities, and the like. Configuration control and related recordkeeping during the same periods were not without data gaps, so this lack of information essentially manifested itself as "unknowns" or "anomalies" during the course of performing routine project work. Each time an unknown was encountered, work stopped and the situation had to be reassessed to establish an appropriate path forward to ensure worker safety and identification of any new hazards. Energized electrical systems that could not be isolated in CPP-603 were found while excavating to the vault in Phase I. This instance required an outage of all electrical systems in the southwestern part of INTEC for several days to allow the project crews to continue excavation and remove old utility systems in order to meet a critical milestone for tank removal. The lesson learned was "plan for the unknown to occur" in work control documentation, which provides the project team the ability to address likely "unknown" scenarios without interrupting all ongoing work, or at least establishes a set path and a support organization (i.e., technical response team) allowing for quick resolution to avoid extended schedule slippage and downtime costs.

- The initial activities identified by the HMWA/RCRA Closure Plan required the characterization of the tank contents. There was not an easy access to the tank so a remote sampling effort was attempted and then a manned entry. Both efforts failed and a significant amount of time and money were expended as well as risks encountered. The lesson learned in this case related to making reasonable goals during the initial development of the high-level guidance documents, such as the closure plan and the RD/RA WP. Hindsight allowed the team to recognize the characterization could have waited until the vault was opened with little impact to the project. Keeping it simple would have been a better approach.

- $\quad$ Performing dry runs of complicated rigging systems related to the lifting of the tank from the vault and attaching the tie-down systems to the tank and container in preparation for transit paid dividends in avoiding aborted attempts due to incorrect or inadequate tools and worker confusion. 
9-2 


\section{SITE CONTACT INFORMATION}

Table 10-1 provides contacts for the CPP-69 project.

Table 10-1. Contact information for the CPP-69 project.

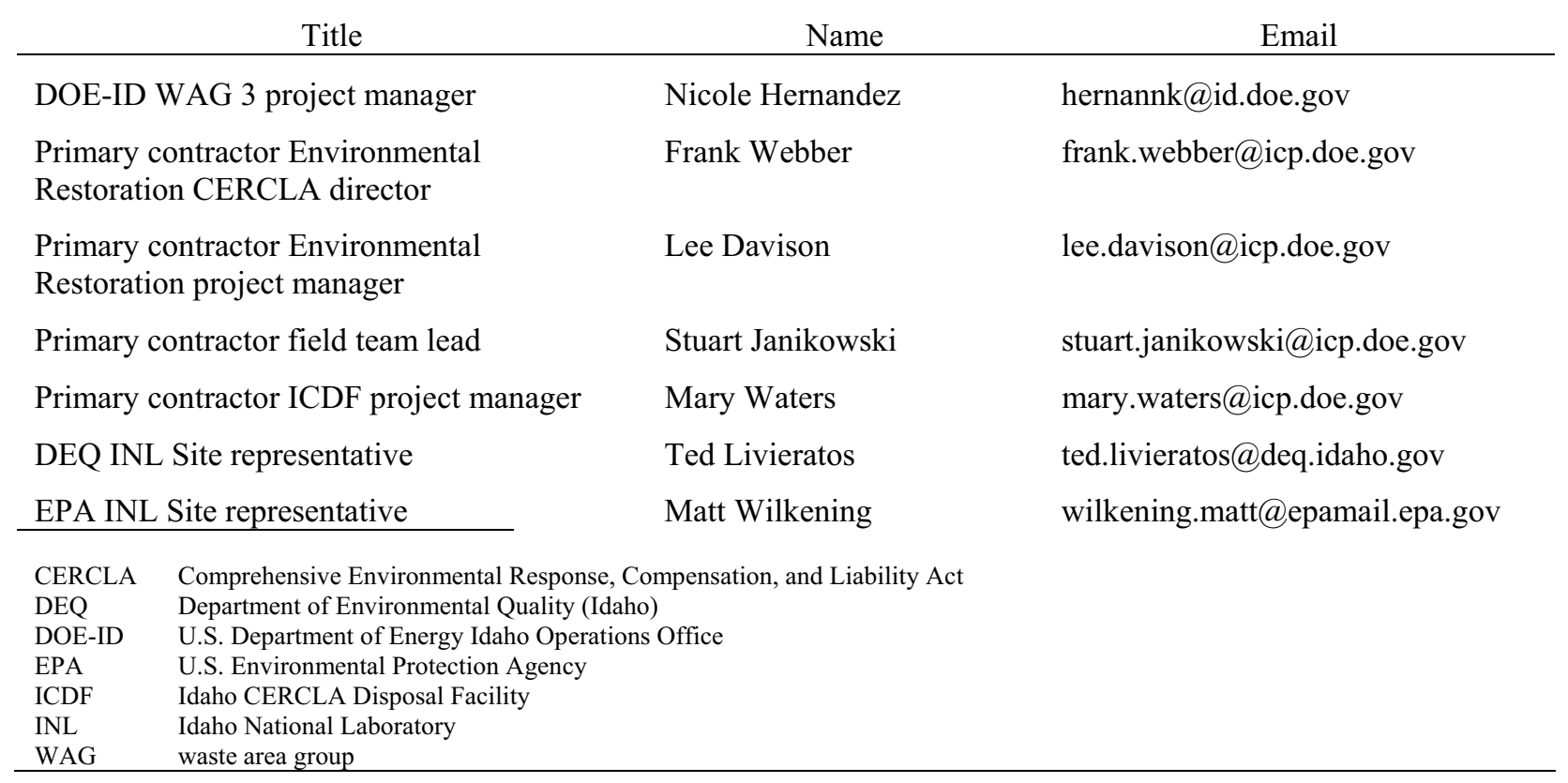


10-2 


\section{REFERENCES}

40 CFR 264, Appendix IX, 2008, "Ground-Water Monitoring List," Code of Federal Regulations, Office of the Federal Register, April 2008.

40 CFR 265, Subpart G, 2006, "Closure and Post-Closure," Code of Federal Regulations, Office of the Federal Register, July 2006.

40 CFR 300.440, 2009, "Procedures for Planning and Implementing Off-Site Response Actions," Code of Federal Regulations, Office of the Federal Register, January 2009.

Butler, J. Lane, CH2M WG Idaho, LLC, letter to Richard B. Provencher, U.S. Department of Energy Idaho Operations Office, February 16, 2006, "Contract No. DE-AC07-05ID14516 - Prefinal Inspection Report for Operable Unit 3-13, Group 7, SFE-20 Hot Waste Tank System, Phase I Activities," CCN 302109.

DEQ, 2003, "HWMA/RCRA Closure Plan for the VES-SFE-20 Hot Waste Tank System at the INEEL Idaho National Technology and Engineering Center," Idaho Department of Environmental Quality, June 19, 2003.

Dieter, Thomas J., CH2M WG Idaho, LLC, letter to Daryl F. Koch, Idaho Department of Environmental Quality, and Larry Gadbois, U.S. Environmental Protection Agency, January 23, 2009, "Transmittal of the INTEC Operable Unit 3-13, Group 3, Sites CPP-01, CPP-04, CPP-05, CPP-09, CPP-10, CPP-11, CPP-69, and CPP-130 Pre-Final/Final Inspection Report," CCN 308013.

DOE-ID, 1991, Federal Facility Agreement and Consent Order for the Idaho National Engineering Laboratory, Administrative Docket No. 1088-06-29-120, U.S. Department of Energy Idaho Operations Office, U.S. Environmental Protection Agency Region 10, Idaho Department of Health and Welfare, December 4, 1991.

DOE-ID, 1997, Comprehensive Remedial Investigation/Feasibility Study for the Idaho Chemical Processing Plant OU 3-13 at the INEEL_Part A, RI/BRA Report (Final), DOE/ID-10534, Rev. 0, U.S. Department of Energy Idaho Operations Office, November 1997.

DOE-ID, 1999, Final Record of Decision, Idaho Nuclear Technology and Engineering Center, Operable Unit 3-13, Idaho National Engineering and Environmental Laboratory, Idaho Falls, Idaho, DOE/ID-10660, Rev. 0, U.S. Environmental Protection Agency, Region 10; Idaho Department of Environmental Quality; U.S. Department of Energy Idaho Operations Office, October 1999.

DOE-ID, 2002, Quality Assurance Project Plan for Waste Area Groups 1, 2, 3, 4, 5, 6, 7, 10 and Inactive Sites, DOE/ID-10587, Rev. 7, U.S. Department of Energy Idaho Operations Office, September 2002.

DOE-ID, 2003a, Characterization Work Plan for the VES-SFE-20 Hot Waste Tank at INTEC, DOE/ID-10747, Rev. 4, U.S. Department of Energy Idaho Operations Office, September 2003.

DOE-ID, 2003b, Field Sampling Plan for the VES-SFE-20 Hot Waste Tank System at INTEC, DOE/ID-11047, Rev. 0, U.S. Department of Energy Idaho Operations Office, June 2003. 
DOE-ID, 2006a, Operable Unit 3-14 Tank Farm Soil and Groundwater Remedial Investigation/Baseline Risk Assessment, DOE/NE-ID-11227, Rev. 0, U.S. Department of Energy Idaho Operations Office, April 2006.

DOE-ID, 2006b, Operable Unit 3-13, Group 3, Other Surface Soils Remediation Sets 4-6 (Phase II) Remedial Design/Remedial Action Work Plan, DOE/ID-11254, Rev. 0, U.S. Department of Energy Idaho Operations Office, July 2006.

DOE-ID, 2007, Record of Decision for Tank Farm Soil and INTEC Groundwater, Operable Unit 3-14, Idaho Cleanup Project, Idaho National Laboratory Site, DOE/ID-11296, Rev. 0, U.S. Department of Energy Idaho Operations Office; U.S. Environmental Protection Agency, Region 10; Idaho Department of Environmental Quality, Idaho Falls, Idaho, May 2007.

DOE-ID, 2008, Remedial Design/Remedial Action Work Plan for the VES-SFE-20 Hot Waste Tank System, DOE/ID-11048, Rev. 2, U.S. Department of Energy Idaho Operations Office, January 2008.

EDF-2360, 2002, “TRU Calculations for SFE-20 Waste Tank," Rev. 0, Idaho National Engineering and Environmental Laboratory, August 2002.

EDF-6655, 2006, "Supporting Risk Evaluations for WAG 3 Group 3, Phase II RD/RA Work Plan," Rev. 0, Idaho Cleanup Project, Idaho National Laboratory, October 2006.

EPA, 1988, "Guidance for Conducting Remedial Investigations and Feasibility Studies Under CERCLA," EPA/540/G-89/004, OSWER Directive 9355.3-01, U.S. Environmental Protection Agency, October 1988.

EPA, 1996, "EPA Soil Screening Guidance User's Guide,” EPA/540/R-96/018, U.S. Environmental Protection Agency, July 1996.

EPA, 2007, Radionuclide Toxicity and Preliminary Remediation Goals for Superfund, http://epaprgs.ornl.gov/radionuclides/download/rad_master_prg table_pci.pdf, U.S. Environmental Protection Agency, Web page dated November 13, 2007, Web page visited June 17, 2009.

EPA, 2008, Preliminary Remediation Goals, http://www.epa.gov/region09/superfund/prg/, U.S. Environmental Protection Agency, Region IX, Web page updated December 16, 2008, Web page visited March 19, 2009.

EPA, 2009, Technical Support Center for Monitoring and Site Characterization, Statistical Software ProUCL 4.0 for Environmental Applications For Data Sets with and without Nondetect Observations, http://www.epa.gov/esd/tsc/software.htm, U.S. Environmental Protection Agency, Web page updated May 1, 2009, Web page visited June 16, 2009.

EPA Method 1311, 1992, “Toxicity Characteristic Leaching Procedure,” Rev. 0, U.S. Environmental Protection Agency, July 1992.

EPA Method 3010A, 1992, "Acid Digestion of Aqueous Samples and Extracts for Total Metals for Analysis by FLAA or ICP Spectroscopy,” Rev. 1, U.S. Environmental Protection Agency, July 1992. 
EPA Method 6010C, 2007, "Inductively Coupled Plasma-Atomic Emission Spectrometry," Rev. 3, U.S. Environmental Protection Agency, February 2007. [Note: Method current at the time was 6010B.)

EPA Method 7470A, 1994, "Mercury in Liquid Waste (Manual Cold-Vapor Technique)," Rev. 1, U.S. Environmental Protection Agency, September 1994.

EPA Method 8082A, 2007, "Polychlorinated Biphenyls (PCBs) by Gas Chromatography," Rev. 1, U.S. Environmental Protection Agency, February 2007. [Note: Method current at the time was 8082.)

EPA Method 8260B, 1996, "Volatile Organic Compounds by Gas Chromatography/Mass Spectrometry (GC/MS),” Rev. 2, U.S. Environmental Protection Agency, December 1996.

EPA Method 8270D, 2007, "Semivolatile Organic Compounds by Gas Chromatography/Mass Spectrometry (GC/MS)," Rev. 4, U.S. Environmental Protection Agency, February 2007. [Note: Method current at the time was 8270C.)

ICP, 2005, Characterization Summary Report for Operable Unit 3-13, Group 7, VES-SFE-20 Hot Waste Tank System at INTEC, ICP/EXT-05-00993, Rev. 0, Idaho Cleanup Project, Idaho National Laboratory, September 2005.

IDAPA 58.01.05.009, 2008, "Interim Status Standards for Owners and Operators of Hazardous Waste Treatment, Storage and Disposal Facilities," Idaho Administrative Procedures Act, Idaho Department of Environmental Quality, April 2008.

Rood, S. M., G. A. Harris, and G. J. White, 1996, Background Dose Equivalent Rates and Surficial Soil Metal and Radionuclide Concentrations for the Idaho National Engineering Laboratory, INEL-94/0250, Rev. 1, Idaho National Engineering Laboratory, August 1996.

RPT-622, 2009, Data Quality Assessment and Data Summary Report for the HWMA/RCRA Closure of the VES-SFE-20 Hot Waste Tank System - Soils, Rev. 1, Idaho Cleanup Project, Idaho National Laboratory, May 2009.

WINCO, 1984, Radiological Characterization and Decision Analysis for the VES-SFE-20 Waste Tank and Vault, WINCO-1021, Westinghouse Idaho Nuclear Company, Inc., September 1984.

Verwolf, Mary C., U.S. Department of Energy Idaho Operations Office, letter, to Nicholas Ceto, U.S. Environmental Protection Agency, Region 10, and Daryl F. Koch, Idaho Department of Environmental Quality, August 24, 2005, "Transmittal of the Limitations and Validation Reports for the Characterization of the VES-SFE-20 Hot Waste Tank at the Idaho Nuclear Technology and Engineering Center (FMDP-RFDP-05-083)," CCN 300858. 
11-4 


\section{Appendix A}

Removal of the Tank and Contents 


$$
\text { A-2 }
$$




\section{Appendix A}

\section{Removal of the Tank and Contents}

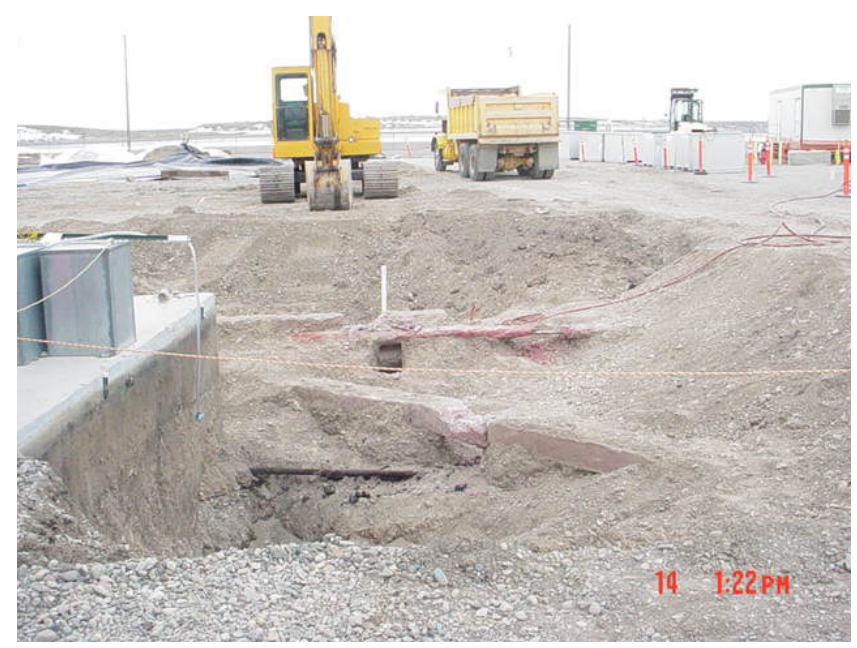

Excavation Phase I and removal of utilities

Pump pit before cleanup
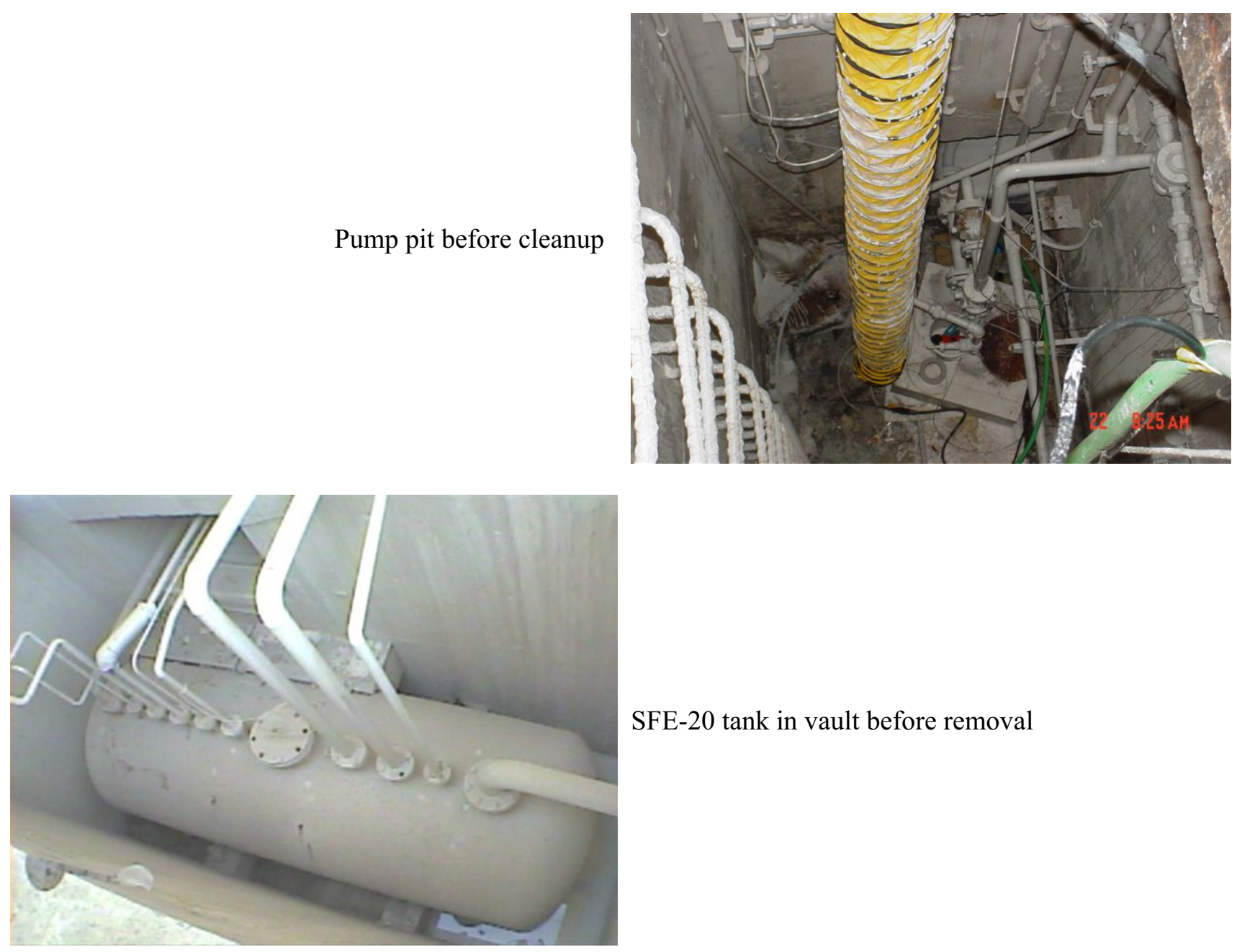

SFE-20 tank in vault before removal 
Process pipe demolition in tunnel
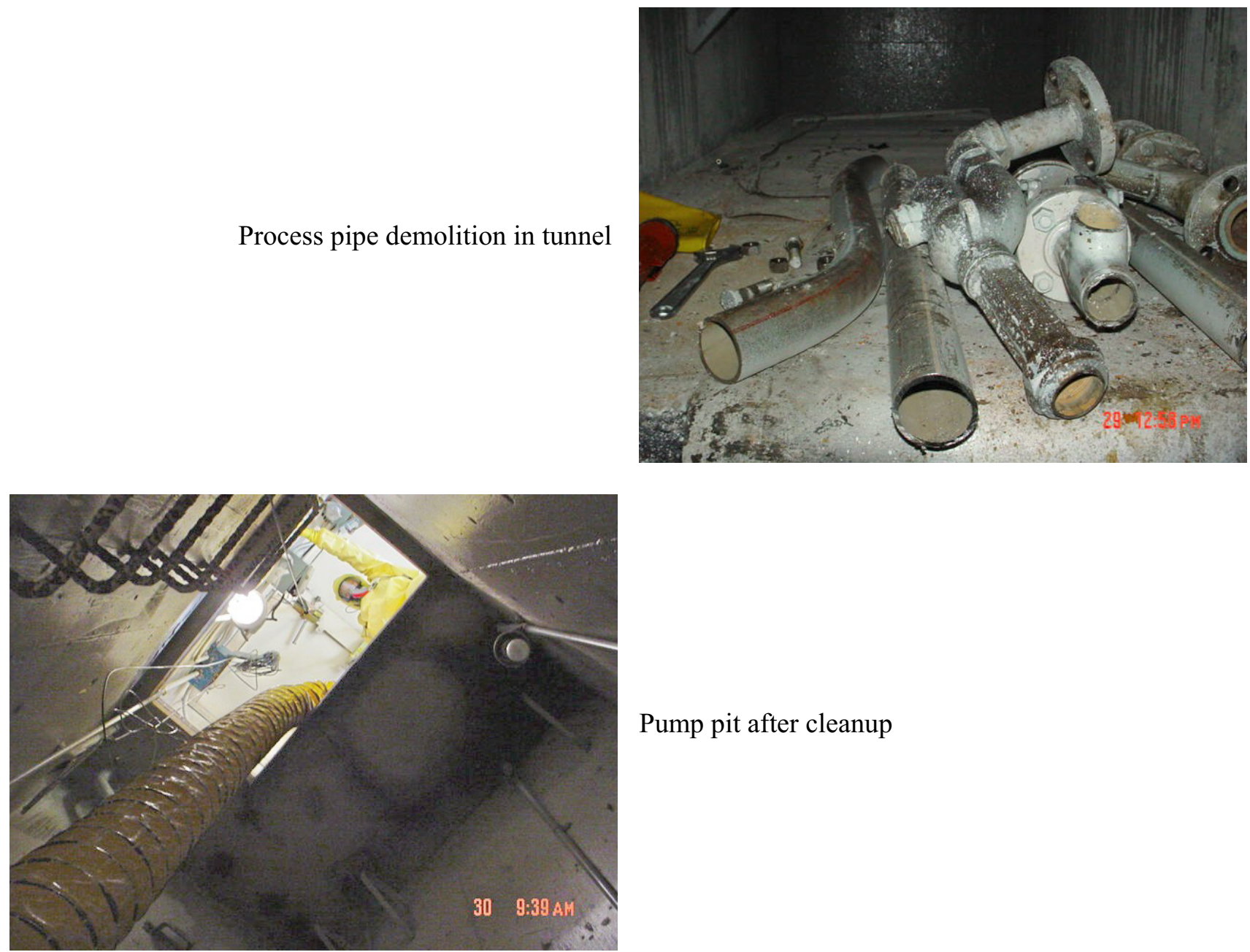

Pump pit after cleanup

SFE-20 tank sampling before removal from vault

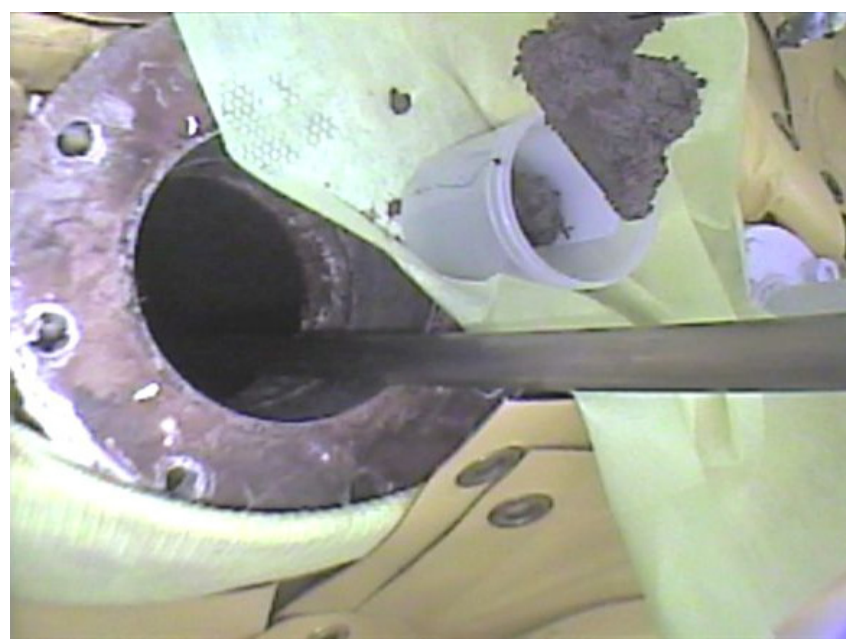




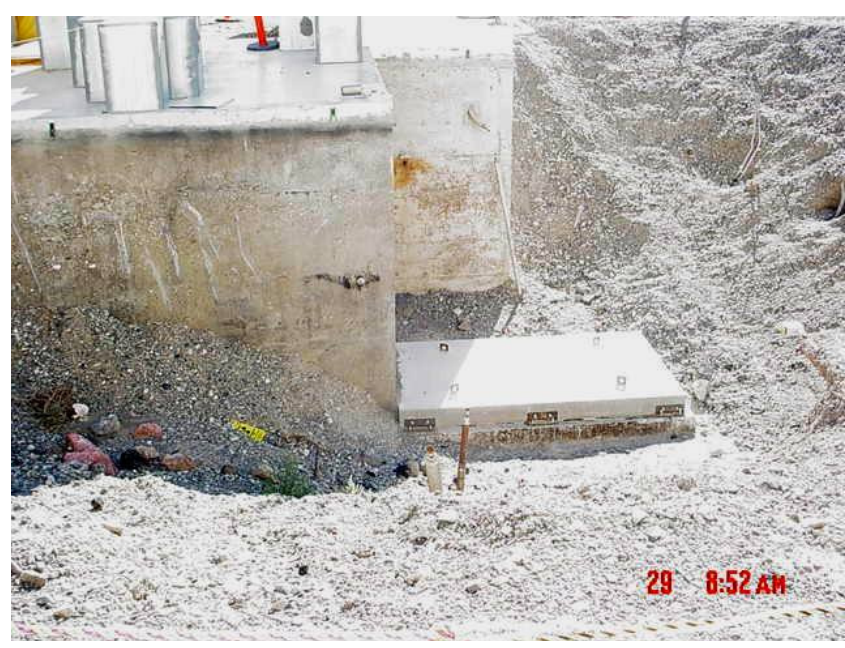

New vault lid before Phase I backfill

Vault backfill and final grade

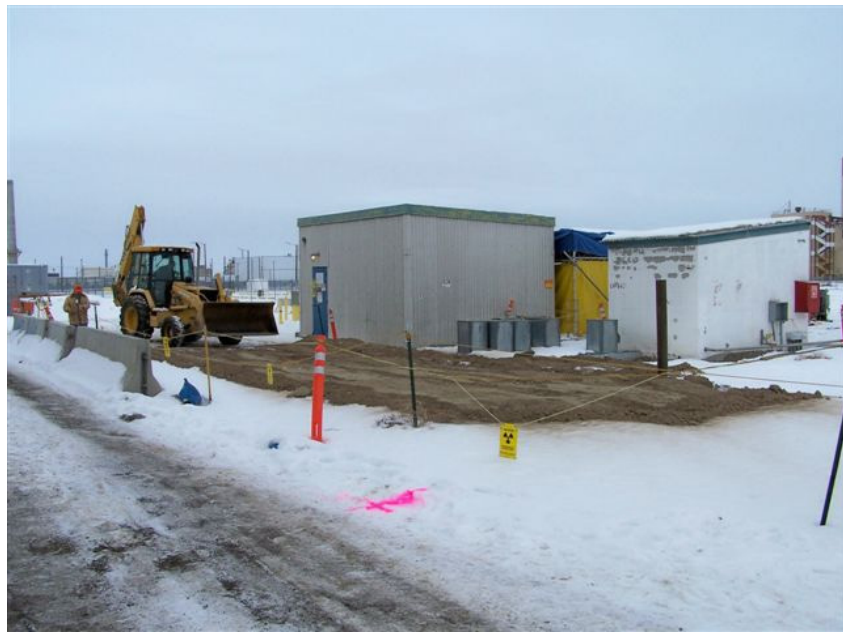


Appendix B

Removal of Pump Pit, Tunnel and Vault 
B-2 


\section{Appendix B}

\section{Removal of Pump Pit, Tunnel and Vault}

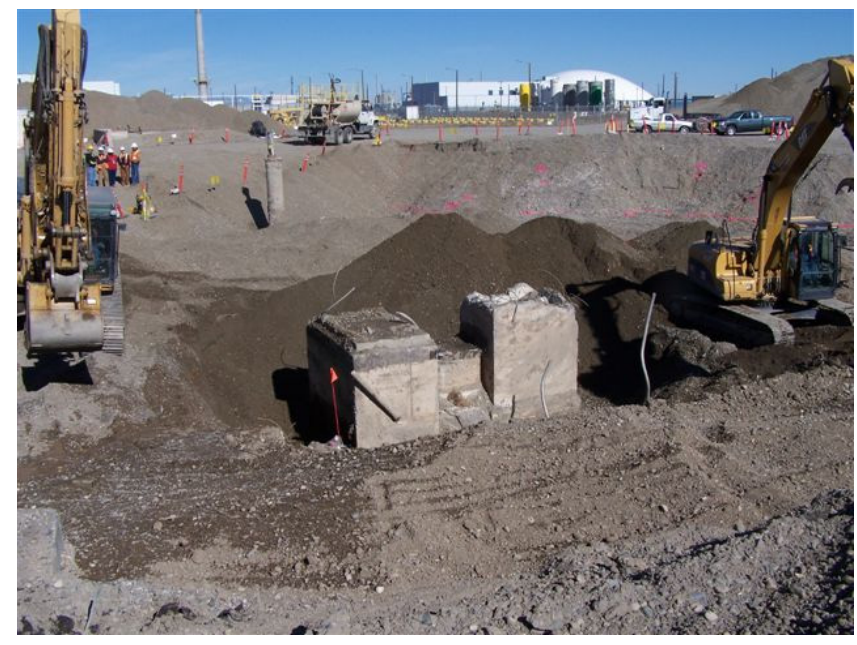

SFE-20 structures ready for demolition

Demolition of SFE-20 vault
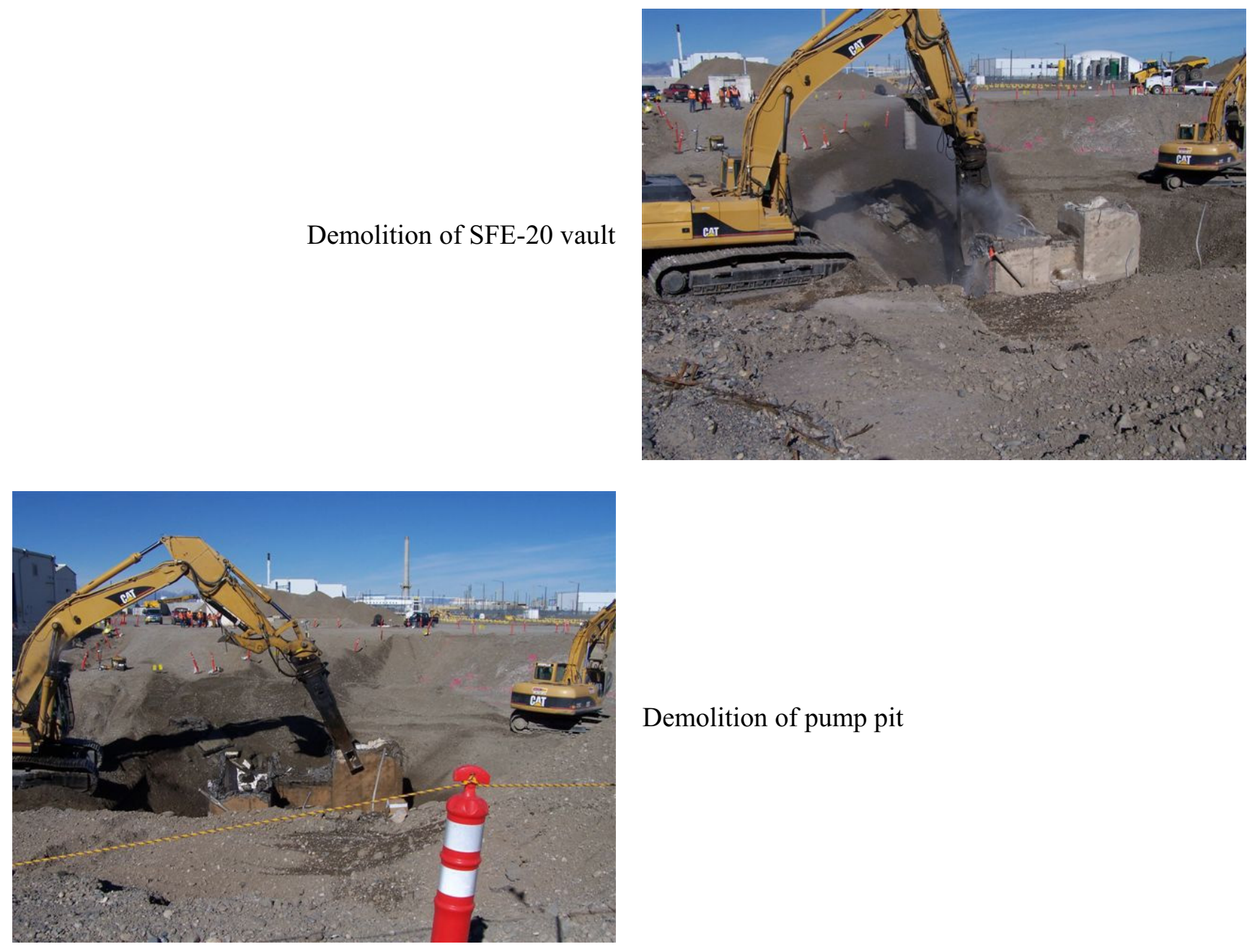

Demolition of pump pit 
Final demolition of structures to base
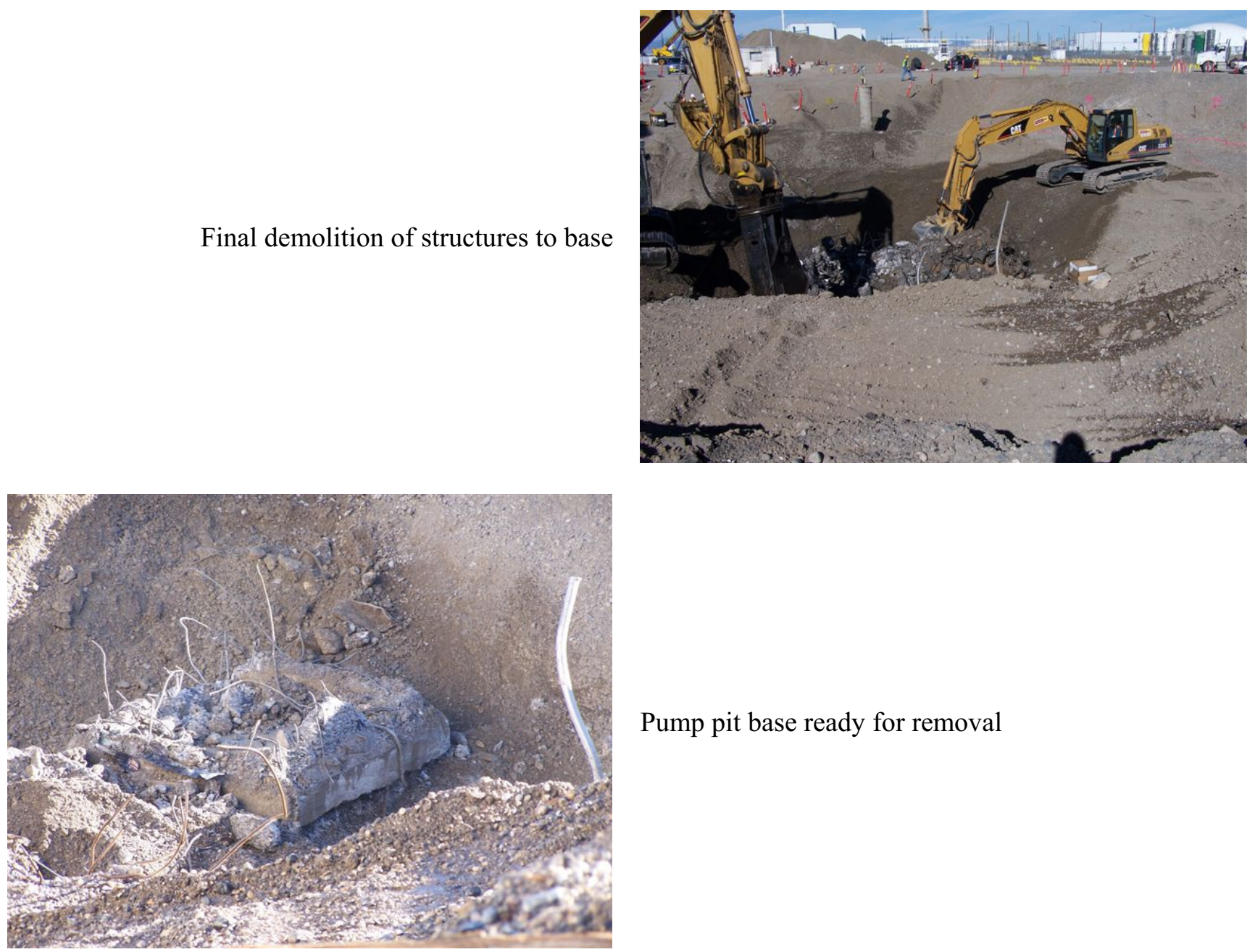

Pump pit base ready for removal

Removal of pump pit base

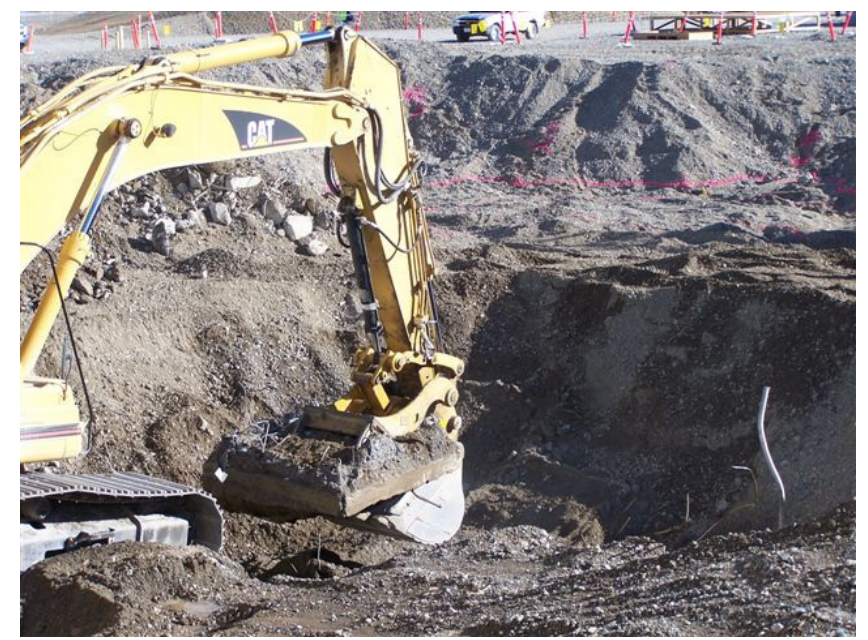




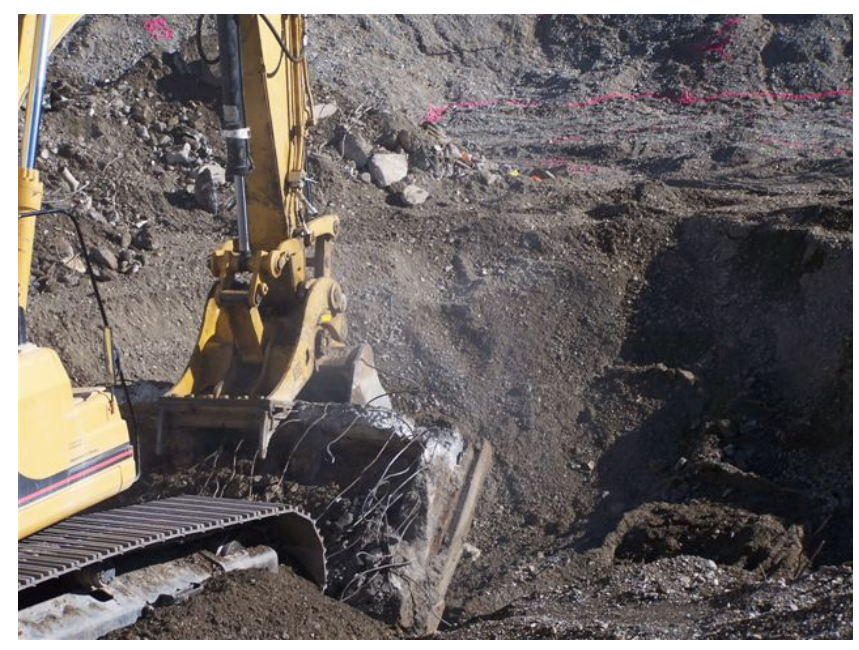

Removal of vault base

Pump pit and vault base staged for sizing and loading
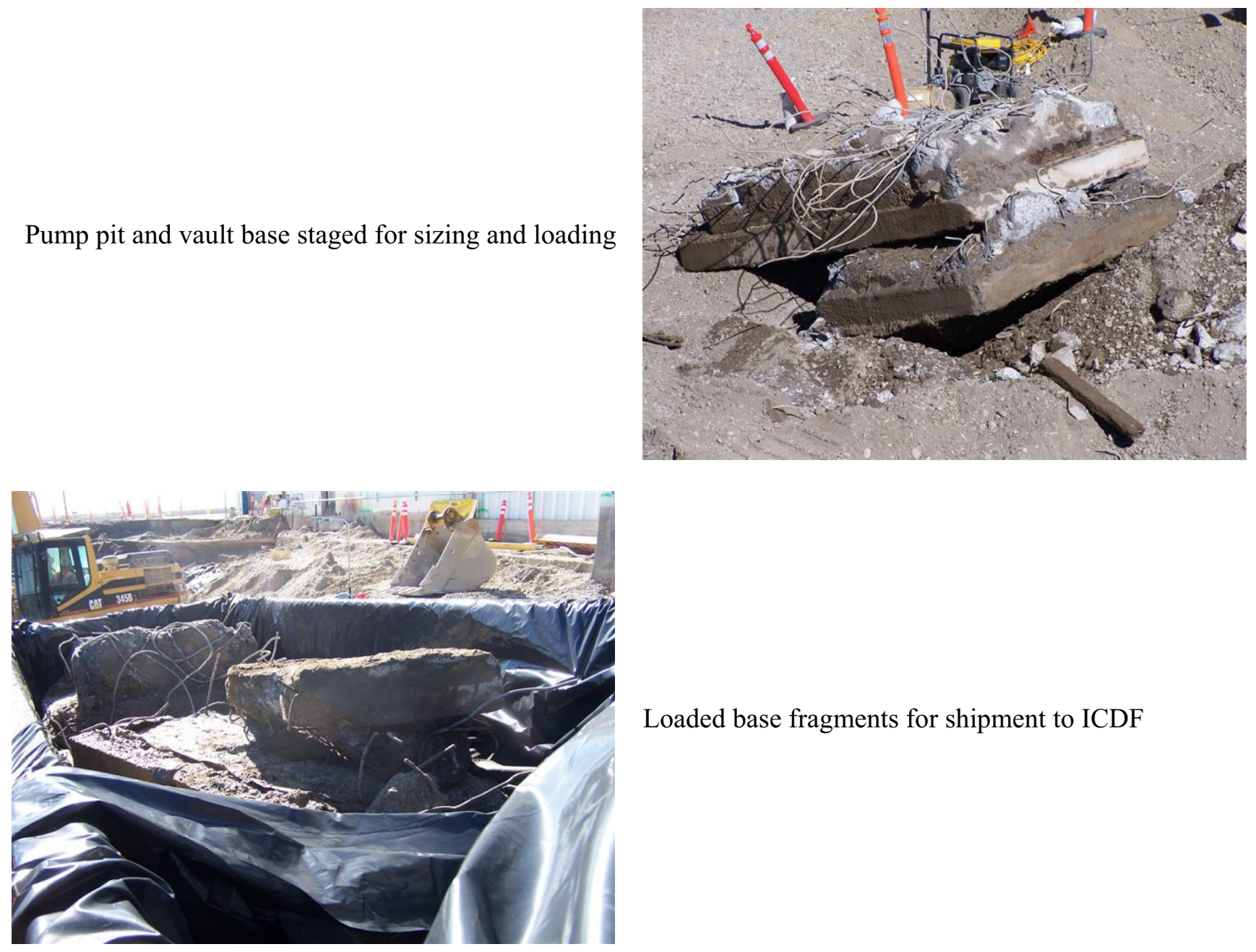

Loaded base fragments for shipment to ICDF 
Finished grade at SFE-20 site

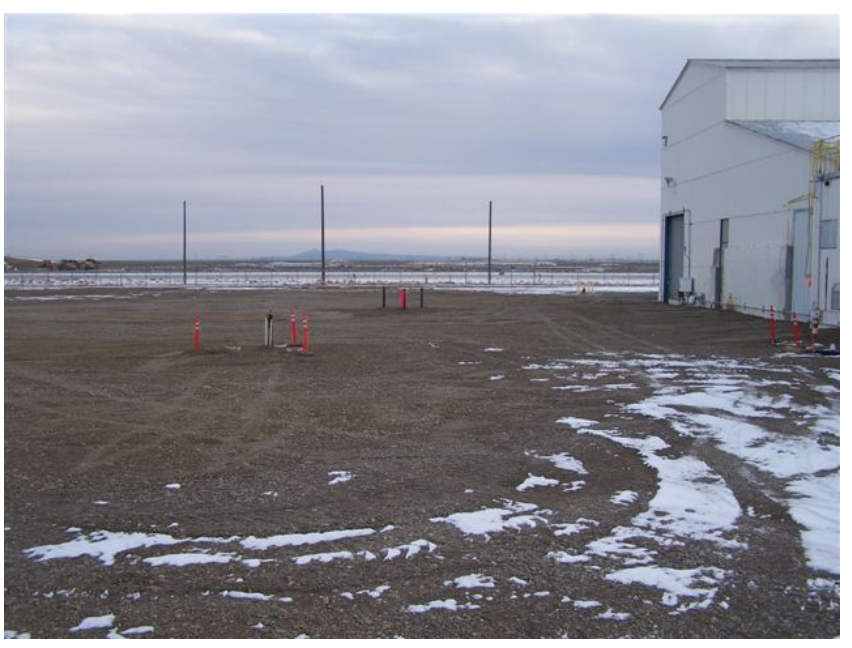




\section{Appendix C}

\section{Off-Site Suitability Determination}


C-2 


\section{Appendix C}

\section{Off-Site Suitability Determination}

\section{Davison, Lee}

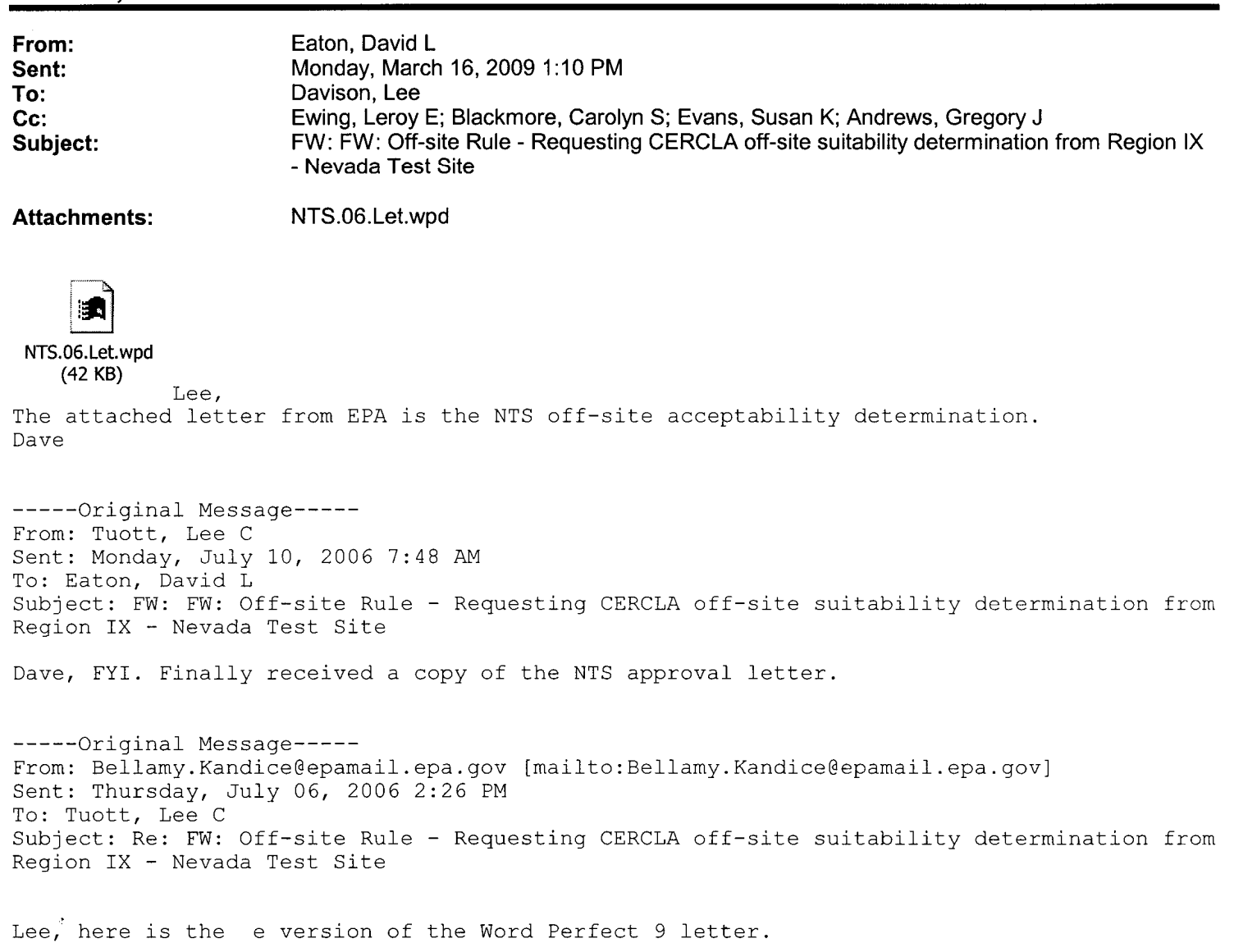

(See attached file: NTS.06. Let.wpd)

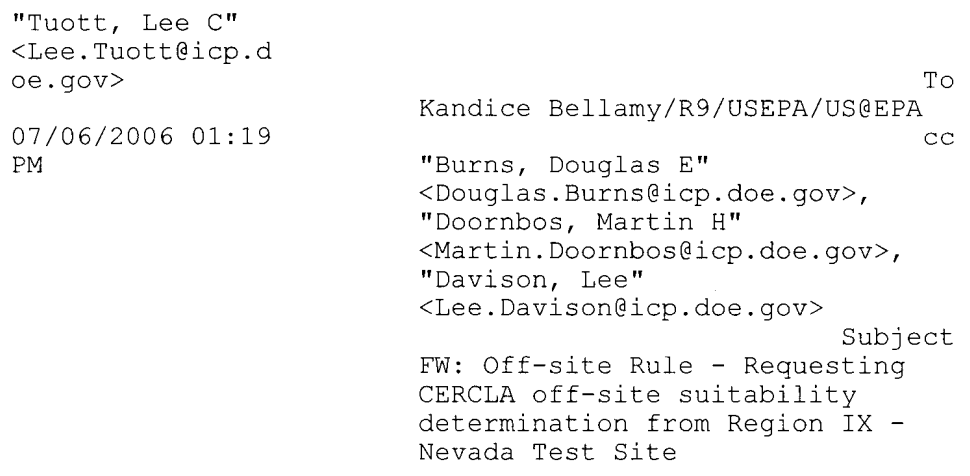


Kandice, the purpose of this note is to follow-up the phone call/message that I left for you today.

Please let me know if there is any additional information that you need concerning the request for an off-site suitability determination for the Nevada Test Site. The specifics for the Nevada Test Site is in the attached email.

Thank you for your attention to this matter.

Lee Tuott

CWI Miscellaneous Sites

Project Environmental Lead

Lee. Tuotteicp.doe.gov

(208) 526-7990 office

(208) $351-7326$ cell

From: Tuott, Lee

Sent: Eriday, April 21, 2006 12:27 PM

To: 'Bellamy. Kandicedepamail. epa.gov'

Cc: Burns, Douglas; Doornbos, Martin

Subject: Off-site Rule - Requesting CERCLA off-site suitability determination from Region IX - Nevada Test Site

Kandice, thank you for the call on this date concerning Region IX's process for providing CERCLA off-site suitability determinations. As discussed, CWI, on behalf of the Department of Energy, Idaho National Laboratory, is planning to send CERCLA waste to the Nevada Test Site for disposal. The CERCLA waste will be a treated mixed waste (radiological and hazardous) that will meet the facility's waste acceptance criteria.

The information on the facility that will receive the treated CERCLA waste for disposal is as follows:

Bechtel Nevada for US DOE

Waste Management Nevada Test Site - Zone 2

Mercury, NV 89023

EPA ID: NV3890090001

Please provide a CERCLA off-site suitability determination for this facility.

Thank you for your atlention to this matler.

Lee Tuott

CWI Miscellaneous Sites

Project Environmental Lead

Lee.Tuottaicp.doe.gov

(208) 526-7990 office

(208) $351-7326$ cell 


\section{UNITED STATES ENVIRONMENTAL PROTECTION AGENCY \\ REGION IX \\ 75 Hawthorne Street \\ San Francisco, CA 94105}

June 26, 2006

Stephen A. Mellington

Deputy Assistant Manager for

Environmental Management for DOE/NV

Nevada Operations Office

P.O. Box 98518

Las Vegas, Nevada 89193-8518

RE: EPA Determination of Continuing Acceptability Pursuant to the CERCLA

Off-Site Rule for the Department of Energy, Nevada Test Site and Clarification

Concerning of Types of Waste Acceptable for Disposal from Off-Site Generators

Dear. Mr. Mellington:

The purpose of this letter is to provide clarification concerning the types of waste that the Department of Energy, Nevada Test Site may receive under the CERCLA Off-Site Rule [40 CFR §300.440]. By letter dated July 7, 1998, EPA made an initial determination of acceptability under the Off-Site Rule for the acceptance of low-level radioactive waste in Areas 3 and 5 at the Nevada Test Site. Correspondence from EPA dated December 4, 1998 discussed definitional aspects of 'low-level' waste and materials from Fernald Environmental Management Project FEMP OU4.

On November 21, 2005, the Nevada Division of Environmental Protection issued a permit for the Pit 3 Mixed Waste Disposal Unit (MWDU) and determined that the Waste Analysis Plan revision dated September 8, 2005 was adequate for purposes of characterization of on-site and off-site generated Low Level Mixed Waste (LLMW). The Nevada Test Site (NTS) may now receive Low Level Mixed Waste (LLMW) in Pit 3 located within the boundaries of the Area 5 Radioactive Waste Management Site (RWMS) in addition to receiving Low Level Radioactive Waste in Areas 3 and 5 in accordance with all applicable state and federal agreements and permits.

On May 18, 2006, a representative of the United States Environmental Protection Agency (USEPA) met with staff and management at the Nevada Operations Office and made a site visit at the Department of Energy (DOE) Nevada Test Site (NTS) with a representative of the Nevada Division of Environmental Protection. The purpose of the evaluation was to make a 
determination of continuing acceptability. Information gathered during the meeting and site visit supports a determination of continued acceptability to receive CERCLA waste.

On September 16, 1993, EPA amended the National Oil and Hazardous Substances Pollution Contingency Plan (NCP), 40 CFR Part 300, by adding Section 300.440, now known as the Off-Site Rule ("Rule"). The Rule codified the requirements contained in Section 121 (d)(3) of CERCLA, 42 U.S.C. $\$ 9621$ (d)(3), and incorporated many provisions of EPA's former OffSite Policy. The Rule established criteria and procedures for determining whether facilities are acceptable for the receipt of CERCLA waste.

In accordance with the Rule, EPA reserves the right to re-evaluate the acceptability of DOE Nevada Test Site (NTS) to receive CERCLA waste should any new information affecting this determination be obtained in the future.

If you have any questions concerning this matter, please contact Kandice Bellamy, Region 9's CERCLA Off-Site Rule Coordinator, at (415) 972-3304.

Sincerely,

Kandice Bellamy, CERCLA Off-Site Rule Coordinator

cc: E. Frank DiSanza, Director, Waste Management Divisions, DOE/NV Mr. J. Carilli, Low-Level Waste Project Manager, DOE/NV

Sharon A. Hejazi, Office of Chief Counsel, DOE/NV

Tim Murphy, Chief, Bureau of Federal Facilities, Nevada Division of Environmental Protection 
Appendix D

\section{Manifest and Land Disposal Restriction Certifications}


D-2 


\section{Appendix D}

\section{Manifest and Land Disposal Restriction Certifications}

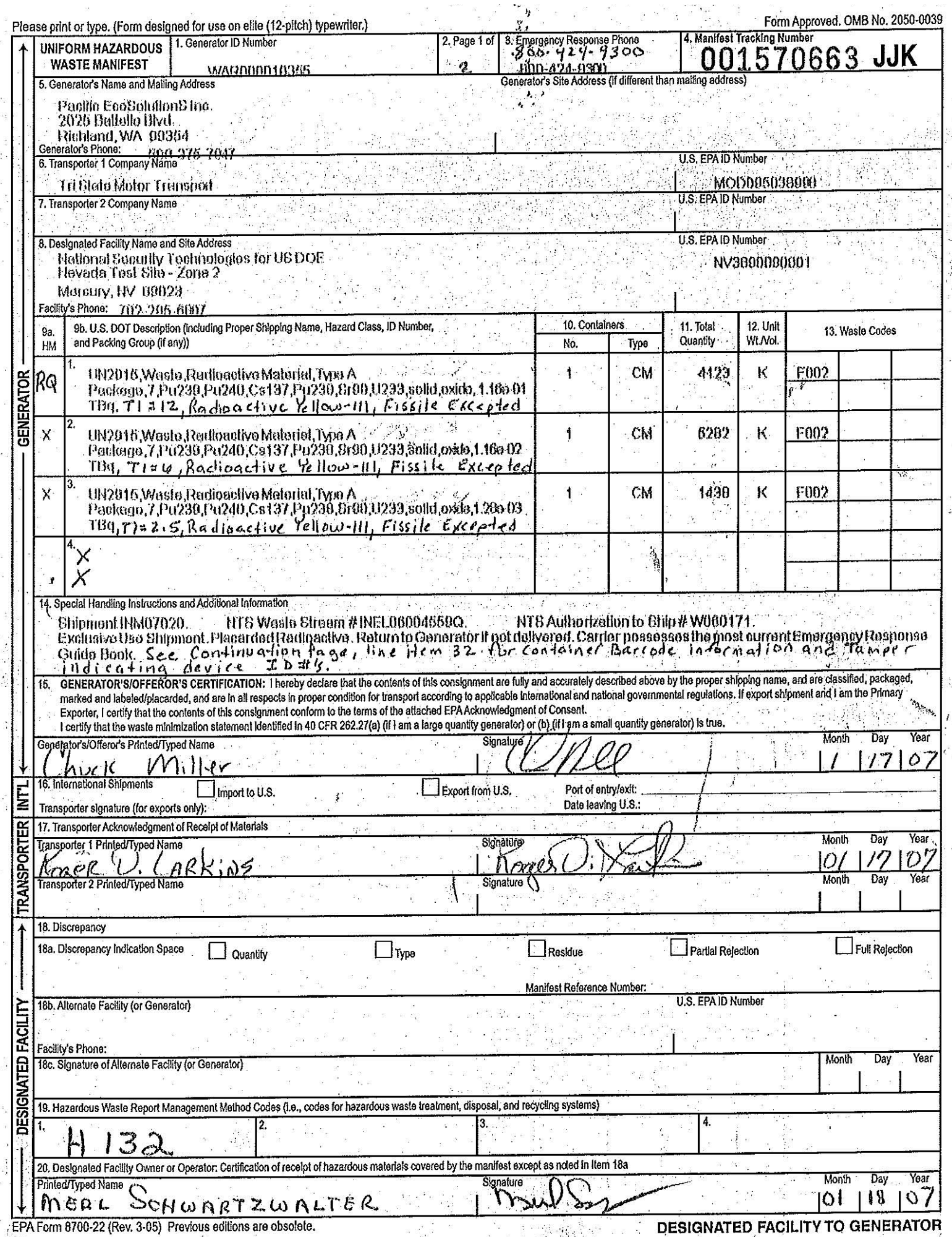




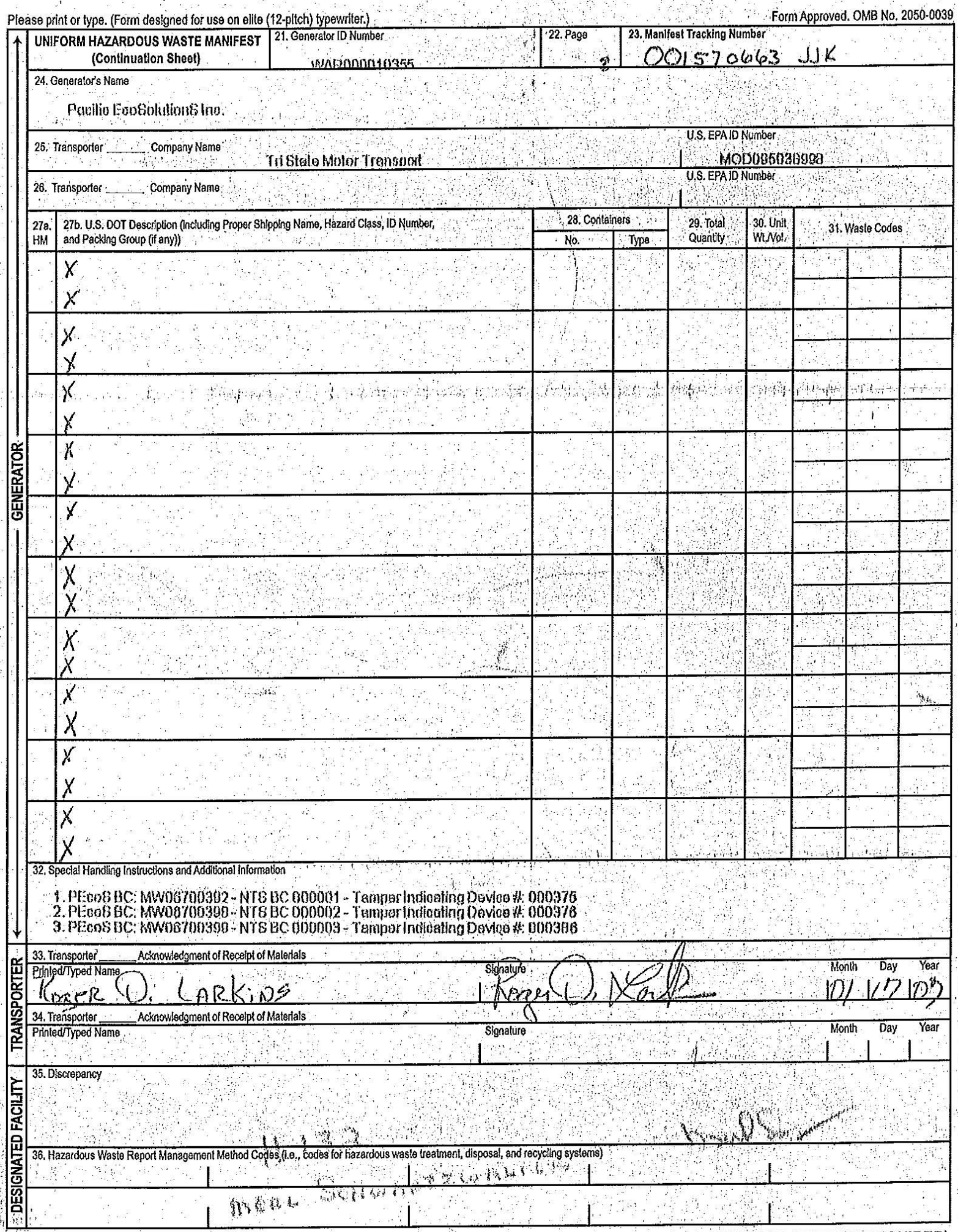




\section{Land Disposal Restrictions Notification and Certification Form}

1. Generator and Shipment Information

Generator: Pacific EcoSolutions inc.

EPA ID \#: $\quad$ WAR000010355

Manifest \#: 001570663 JJK (INM07020)

Profile \#. 2006-INEL-0007

Containers: See attachment 1 "PIN list"

2. Is waste analysis information attached? $\square$ Yes $\square$ Provided with Waste Profile Sheet $\square$ Not available

3. Wastewater category: $\square$ Wastewater $\square$ Nonwastewater

4. Subcategories and Certification Statements Table

Select the applicable waste code and LDR subcategory or waste description. For each subcategory, select the applicable certification statement code from the Notification and Certification Statements page. The Notification and Certification Statements page must be attached.

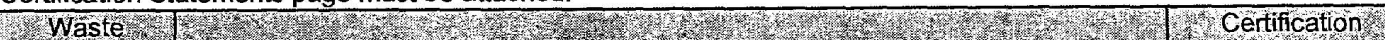

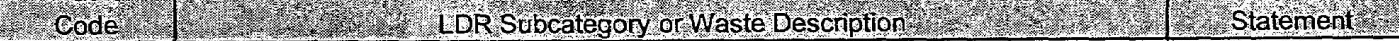

F002 F001 - F005 spent solvent wastes C1

5. Specific LDR constituents: Check any of the following that apply. If any are checked, attach the LDR Constituent Addendum to identify the the Underlying Hazardous Constituents and/or constituents requiring treatment (Does not . apply to Radioactive Lead Solids):

$\square$ Characteristic waste contains Underfying Hazardous Constituents subject to treatment

$\square$ F001 - F005 waste constituents of concern

DF039 waste constituents of concern

D Hazardous debris subject to the alternative treatment standards of 40CFR 258.45

$\square$ Contaminated soil subject to the alternative treatment standards of 40 CFR 268.49 


\section{Notification and Certification Statements}

Generator: Pacific EcoSolutions Inc.

EPA ID \#: WAR000010355

Manifest \# : 001570663 JJK (INM07020)

Profile \#: 2006-INEL-0007

Containers: See attachment 1 "PIN list"

The following notification and/or certification statement(s) apply to the waste on this shipment.

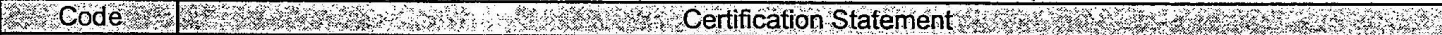

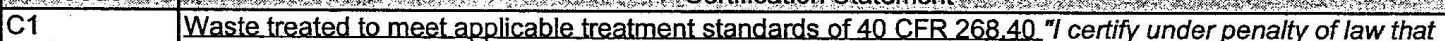
I have personally examined and am familiar with the treatment technology and operation of the treatment process used to support this certification. Based on my inquiry of those individuals immediately responsible for obtaining this information, I believe that the treatment process has been operated and maintained properly so as to comply with the treatment standards specified in 40 CFR 268.40 without impermissible dilution of the prohibited waste. I am aware there are significant penalties for submitting a false certification, including the possibility of fine and imprisonment. "

Name (print): Chuck Miller

Signature:

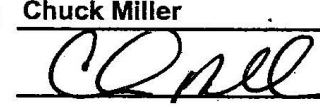

Date: January 11, 2007

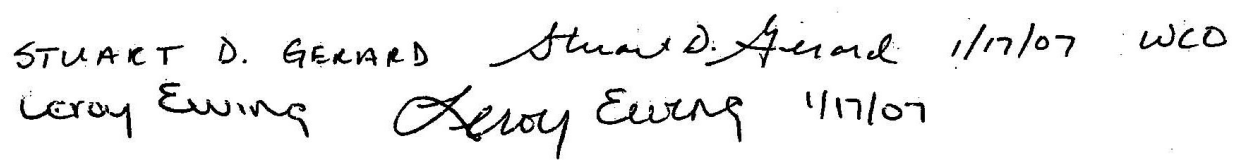




\section{LDR Constituents Addendum}

$\begin{array}{ll}\text { Generator: } & \text { Pacific EcoSolutions Inc. } \\ \text { EPA ID \#: } & \text { WAR000010355 } \\ \text { Manifest \#: } & 001570663 \text { JJK (INM07020) } \\ \text { Profile \#: } & \text { 2006-INEL-0007 } \\ \text { Containers: } & \text { See attachment } 1 \text { "PIN list" }\end{array}$

The code(s) provided in the first column identify those constituents present in the waste that must be identified under 40 CFR 268.7 . The meaning of the codes is as follows:

UHC: Underlying Hazardous Constituent reasonably expected to be present above the UTS level

SOLV: F001-F005 spent solvent constituent in the waste

F039: F039 constituent of concern in the waste

DEBR: Contaminants subject to treatment under the debris alternative treatment standards of 40 CFR 268.45

SOIL: Constituents subject to treatment under the contaminated soil alternative treatment standards of 40 CFR 268.49

RLS: Radioactive Lead Solids subject to treatment under 40 CFR 268.40

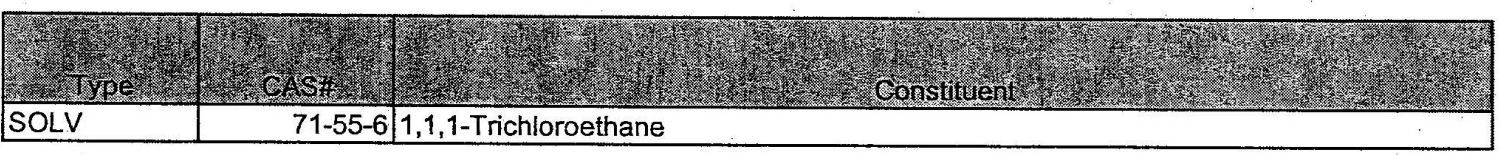


Attachment -1 (PIN list)

Generator:

EPA ID\#:

Pacific EcoSolutions Inc.

Manifest \# :

WAR000010355

001570663 JJK (INM07020)

\begin{tabular}{|l|l|}
\hline \multicolumn{1}{|c|}{ PIN } & Waste Codes \\
\hline PEcoS BC-MW06700398/NTS BC - 000002 & F002 \\
\hline PEcoS BC-MW06700399/NTS BC - 000003 & F002 \\
\hline & \\
\hline & \\
\hline & \\
\hline & \\
\hline & \\
\hline & \\
\hline & \\
\hline
\end{tabular}

LDR PIN list, Page 4 of 5 


\section{Land Disposal Restrictions Notification and Certification Form}

1. Generator and Shipment Information

Generator: Pacific EcoSolutions, Inc.

EPA ID \#: WAR000010355

Manifest \# : 001570663 JJK (INM07020)

Profile \#: 2006-INEL-0007

Containers: PEcoS BC - MW06700382 / NTS BC-000001

2. Is waste analysis information attached? $\square$ Yes $\square$ Provided with waste Profile Sheet $\square$ Not available

3. Wastewater category: $\square$ Wastewater $\square$ Nonwastewater

4. Subcategories and Certification Statements Table

Select the applicable waste code and LDR subcategory or waste description. For each subcategory, select the applicable certification statement code from the Notification and Certification Statements page. The Notification and Certification Statements page must be attached.

\begin{tabular}{|c|c|c|c|}
\hline $\begin{array}{c}\text { Waste } \\
\text { Code }\end{array}$ & Certification \\
\hline F002 & F001 - F005 spent solvent wastes & Statement \\
\hline
\end{tabular}

5. Specific LDR constituents: Check any of the following that apply. If any are checked, attach the LDR Constituent Addendum to identify the the Underlying Hazardous Constituents and/or constituents requiring treatment:

$\square$ Characteristic waste contains Underlying Hazardous Constituents subject to treatment

$\checkmark$ F001 - F005 waste constituents of concern

$\square$ F039 waste constituents of concern

$\square$ Hazardous debris subject to the alternative treatment standards of 40CFR 268.45

$\square$ Contaminated soil subject to the alternative treatment standards of 40CFR 268.49 


\section{Notification and Certification Statements}

Generator: Pacific EcoSolutions, Inc.

EPA ID \#: WAR000010355

Manifest \# : 001570663 JJK (INM07020)

Profile \#: 2006-INEL-0007

Containers: PEcoS BC - MW06700382 /NTS BC-000001

The following notification and/or certification statement(s) apply to the waste on this shipment.

\begin{tabular}{|l|l|}
\hline Code & \multicolumn{1}{|c|}{ Certification Statement } \\
\hline $\mathrm{C} 1$ & $\begin{array}{l}\text { Waste treated to meet applicable treatment standards of } 40 \mathrm{CFR} 268.40(40 \mathrm{CFR} 268.7(\mathrm{~b})) \text {. "I certify } \\
\text { under penalty of law that I have personally examined and am familiar with the treatment technology and } \\
\text { operation of the treatment process used to support this certification. Based on my inquiry of those } \\
\text { individuals immediately responsible for obtaining this information, I believe that the treatment process has } \\
\text { been operated and maintained propenly so as to comply with the treatment standards specified in } 40 \mathrm{CFR} \\
268.40 \text { without impermissible dilution of the prohibited waste. I am aware there are significant penalties for } \\
\text { submitting a false certification, including the possibility of fine and imprisonment. " }\end{array}$
\end{tabular}

Name (print): Chuck Miller

Signature:

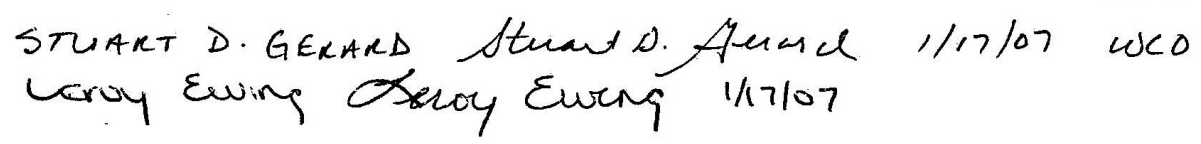


LDR Constituents Addendum

Generator: Pacific EcoSolutions, Inc

EPA ID \#: $\quad$ WAR000010355

Manifest \# : 001570663 JJK (INM07020)

Profile \#: $\quad$ 2006-INEL-0007

Containers: PEcoS BC - MW06700382 / NTS BC-000001

The code(s) provided in the first column identify those constituents present in the waste that must be identified under 40 CFR 268.7 .

The meaning of the codes is as follows:

UHC: Underlying Hazardous Constituent reasonably expected to be present above the UTS level

SOLV: F001-F005 spent solvent constituent in the waste

F039: F039 constituent of concern in the waste

DEBR: Contaminants subject to treatment under the debris alternative treatment standards of 40 CFR 268.45

SOIL: Constituents subject to treatment under the contaminated soil alternative treatment standards of $40 \mathrm{CFR} 268.49$

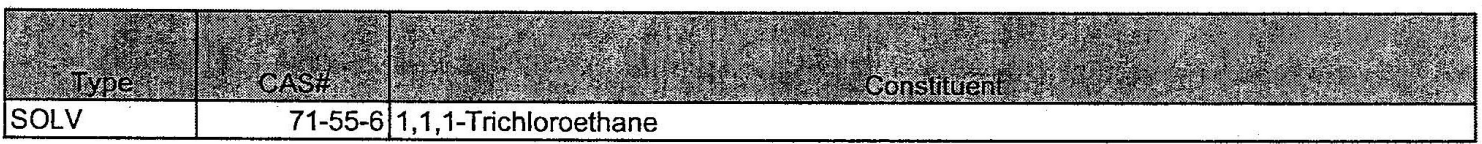


Attachment -1 (PIN list)

Generator: Pacific EcoSolutions, Inc.

EPA ID \#: WAR000010355

Manifest \# : $\quad 001570663$ JJK (INM07020)

\begin{tabular}{|l|l|}
\hline PIN & Waste Codes \\
\hline PEcoS BC - MW06700382 I NTS BC - 000001 & F002 \\
\hline & \\
\hline & \\
\hline & \\
\hline & \\
\hline & \\
\hline & \\
\hline & \\
\hline & \\
\hline & \\
\hline
\end{tabular}

LDR PIN list, Page 4 of 5

D-12 
Appendix E

Certificate of Disposal 
E-2 


\section{Appendix E}

\section{Certificate of Disposal}

\begin{tabular}{|lcr|}
\hline NSTec & CERTIFICATE OF DISPOSAL & $08 / 02 / 06$ \\
Form & Rev. 0 \\
FRM-1929 & (MIXED LOW LEVEL) & Page 1 of 1 \\
\hline
\end{tabular}

\section{National Security Technologies uc \\ For U.S. Department of Energy \\ Waste Management \\ Nevada Test Site - Zone 2 \\ Mercury, NV 89023}

EPA ID NV3890090001

This Certificate acknowledges that the following shipment(s) of manifested MIXED LOW LEVEL waste have been disposed at the Nevada Test Site Radioactive Waste Management Site.

\begin{tabular}{|c|l|l|l|l|}
\hline Shipment Number & $\begin{array}{c}\text { Uniform Hazardous } \\
\text { Waste Manifest Number }\end{array}$ & Date(s) of Disposal & Volume $\left.\mathrm{Ft}^{3} \mathbf{m}^{3}\right)$ & Disposal Process \\
\hline INM07020 & $001570663 \mathrm{JJK}$ & $01 / 18 / 2007$ & $108.76(3.08)$ & Landfill \\
\hline & & & & \\
\hline & & & & \\
\hline & & & & \\
\hline & & & & \\
\hline & & & & \\
\hline
\end{tabular}

This certification is provided as a courtesy to the waste generator for information purposes only.

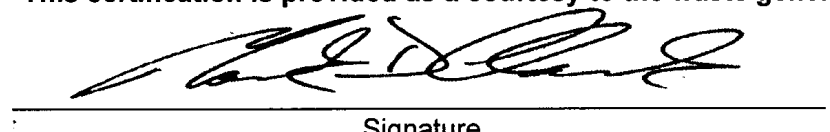

Signature

$03 / 05 / 2007$

Date

Senior Scientist/Environmental Compliance

Title

Instructions:

Shipment Number - enter shipment number from LWIS database.

Uniform Hazardous Waste Manifest Number - enter number from UHWM provided by generator.

Date of Disposal - enter date waste was placed in disposal cell.

Volume - enter shipment volume in cubic feet and equivalent cubic meters in parenthesis.

Disposal Process - enter Landfill. 
E-4 
Appendix F

VES-SFE-20 Tank and Contents Treatment and Disposal 
F-2 


\section{Appendix F}

\section{VES-SFE-20 Tank and Contents Treatment and Disposal}

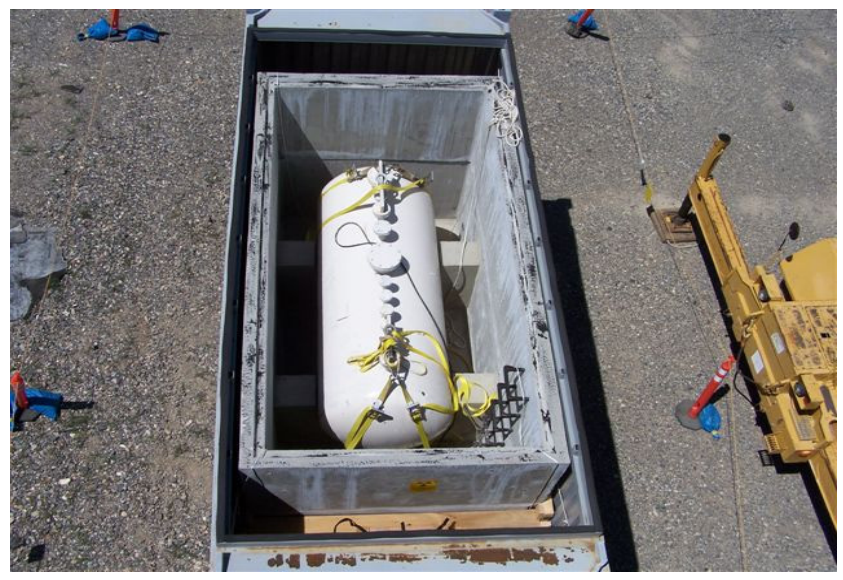

Ariel view of loaded SFE-20 transport container

SFE-20 transport container leaving INTEC for Pecos Treatment Facility
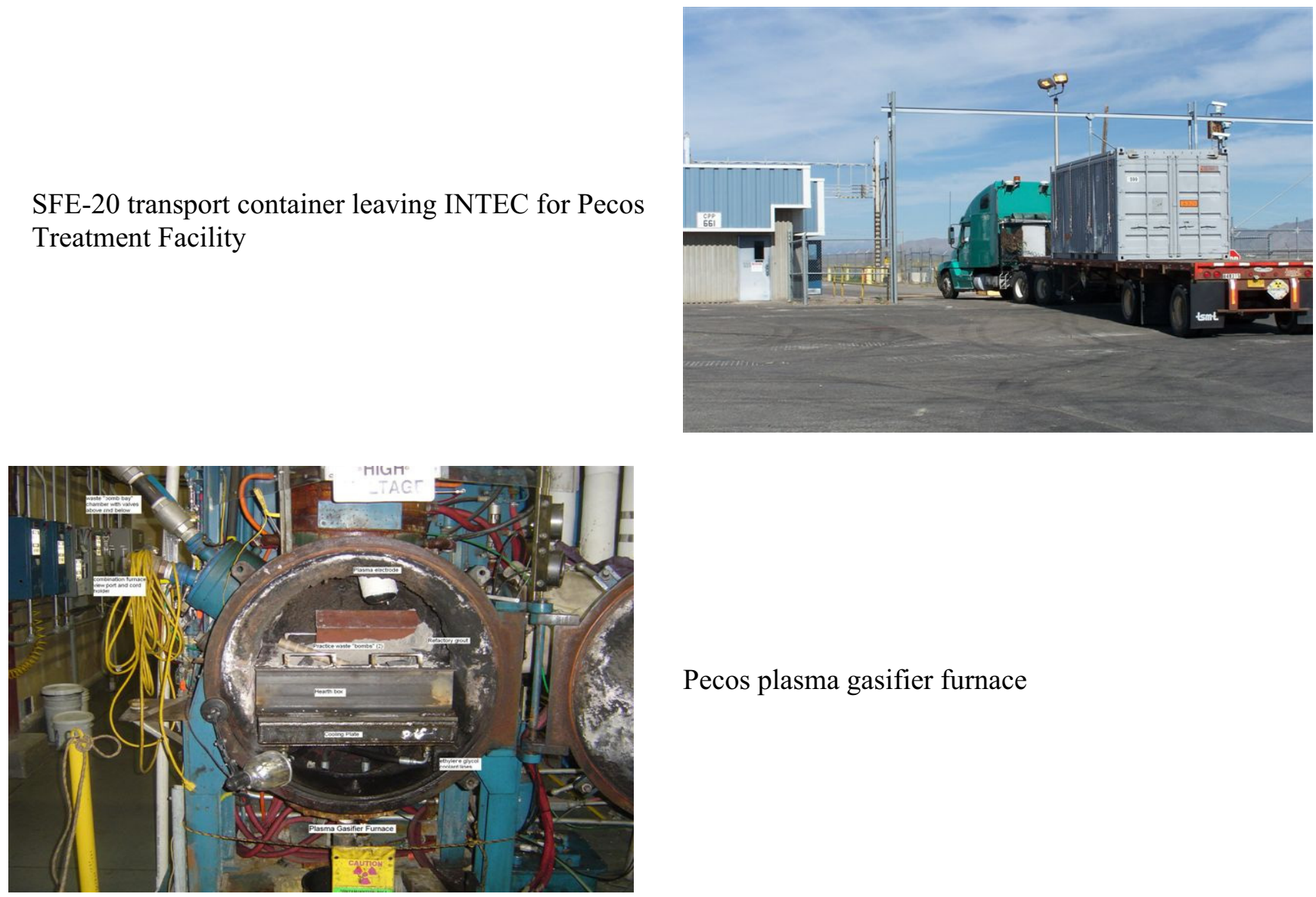

Pecos plasma gasifier furnace 
Glass residue drum with vitrified waste
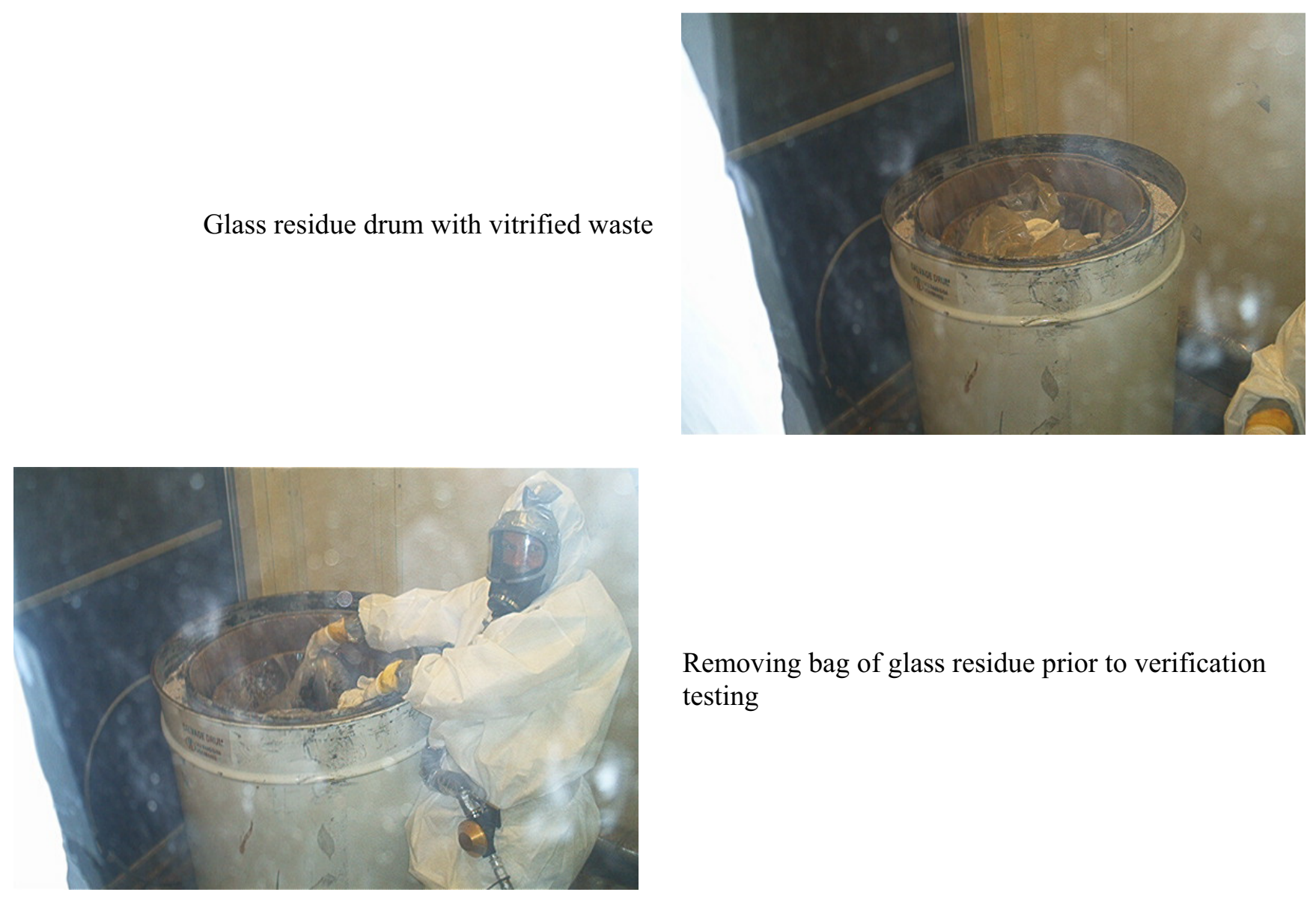

Removing bag of glass residue prior to verification testing

Paint filter test of glass residue

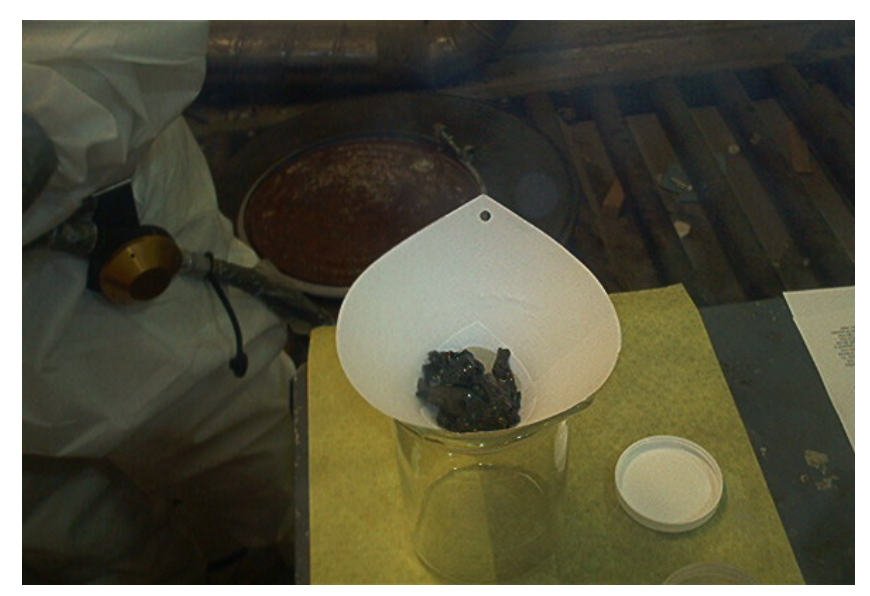




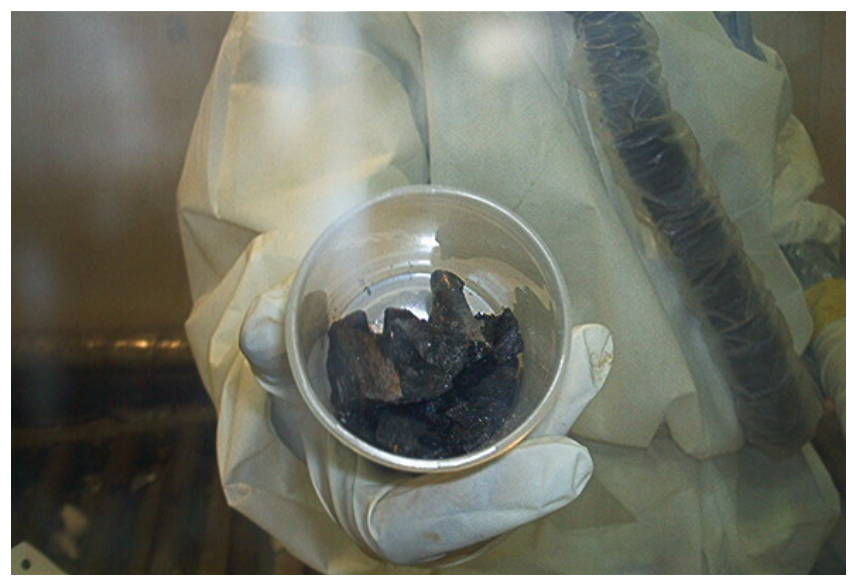

Close-up of glass residue

Kitty litter added to glass residue
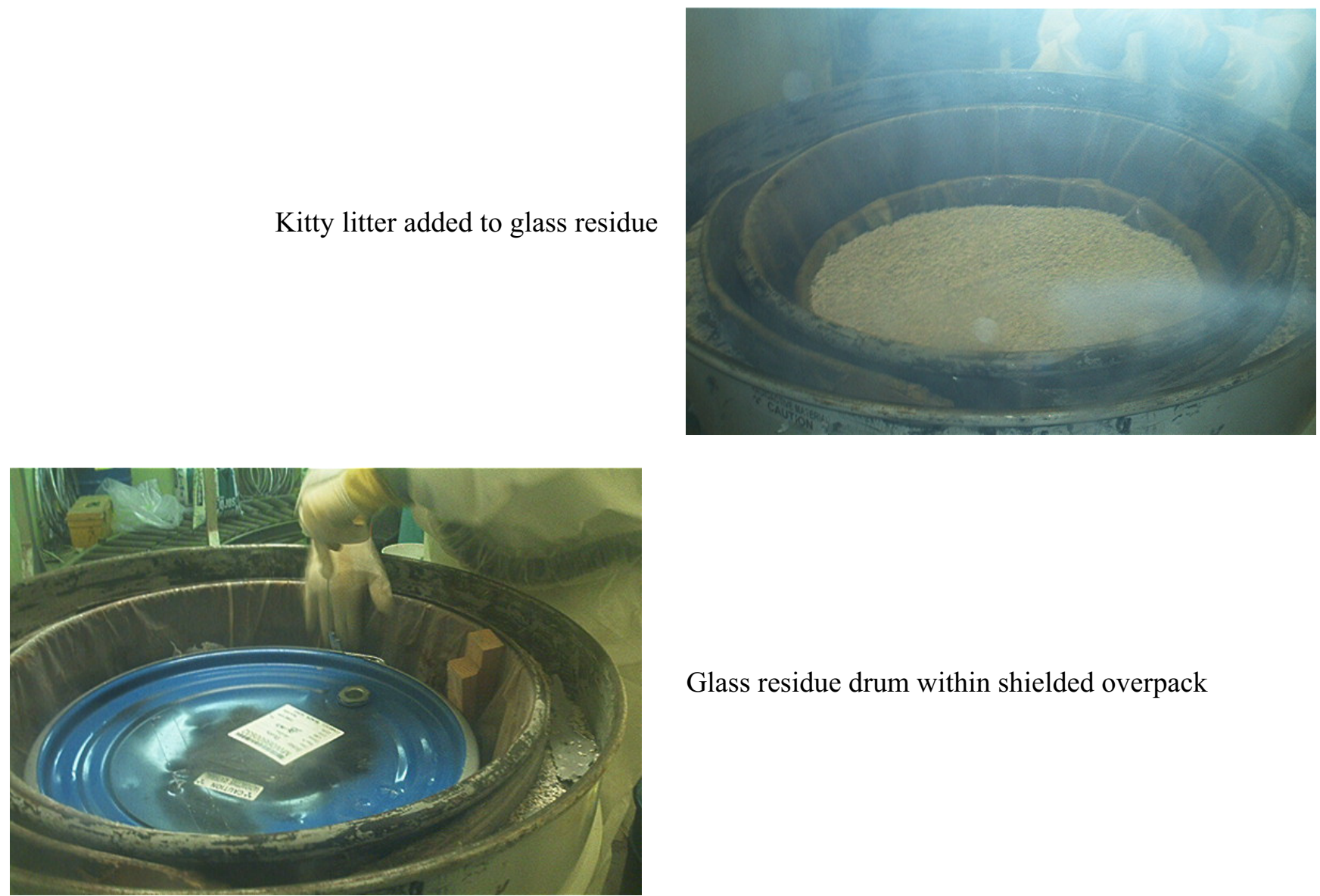

Glass residue drum within shielded overpack 
The SFE20 tank, sludge residue drum positioned inside the disposal container (pre-grout). Two inches of grout was previously poured into the bottom of the disposal container and allowed to cure prior to placement of the residue drum in disposal container.
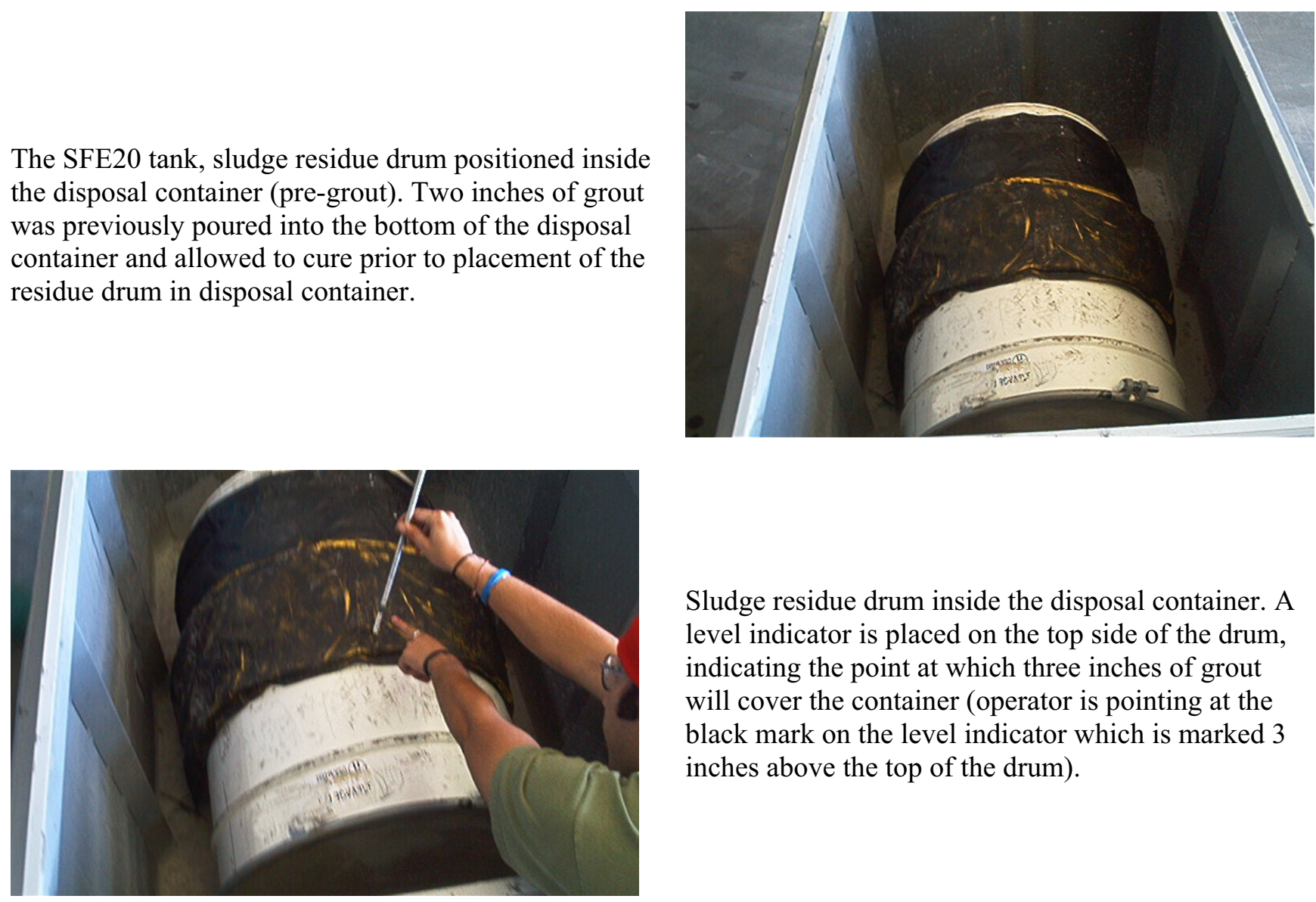

Sludge residue drum inside the disposal container. A level indicator is placed on the top side of the drum, indicating the point at which three inches of grout will cover the container (operator is pointing at the black mark on the level indicator which is marked 3 inches above the top of the drum).

First stage of macro process of the SFE20 Tank sludge residue.

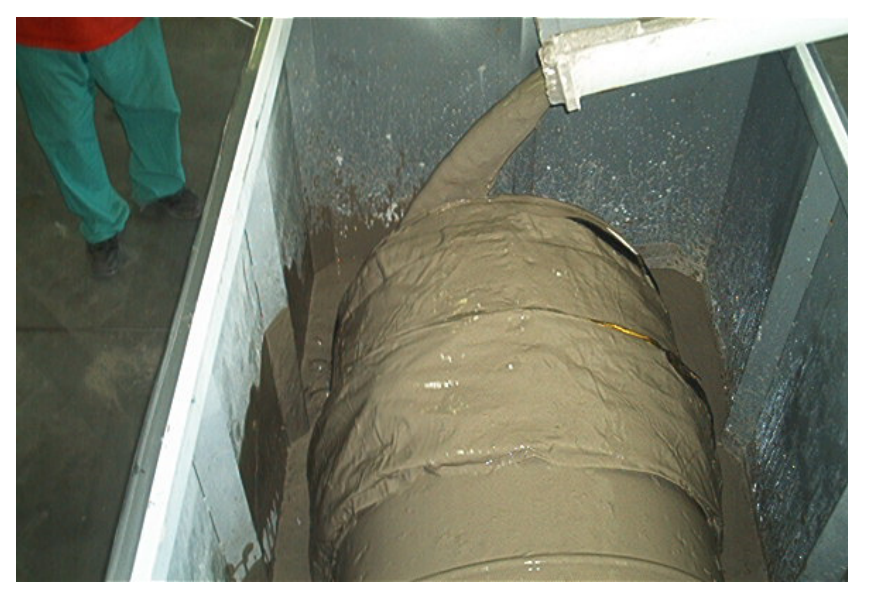




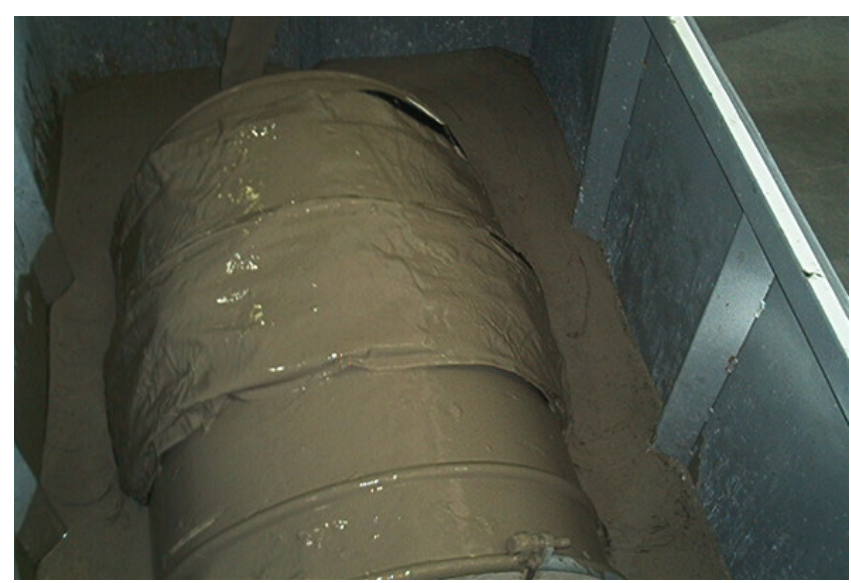

First stage of the macro encapsulation completed. Grout will be allowed to cure 72 hours before the second stage commences.

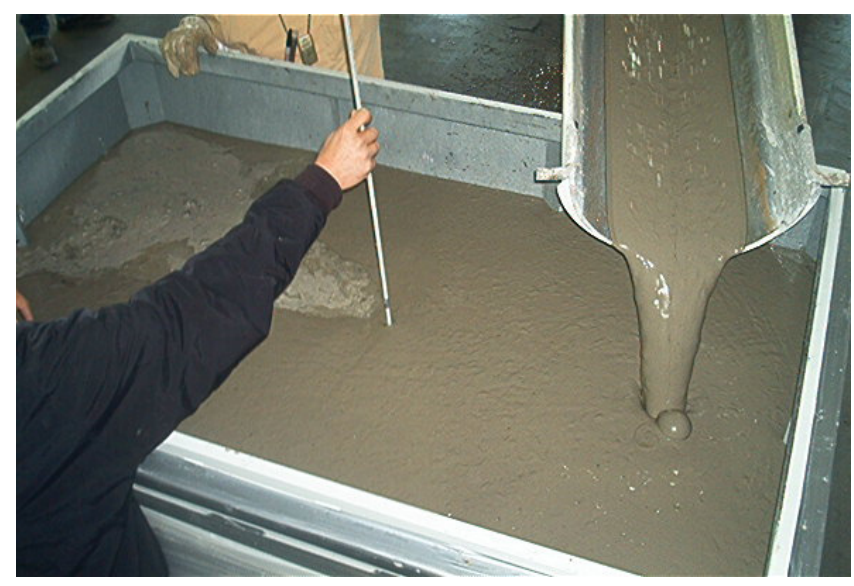

Grout level half way through first pour.

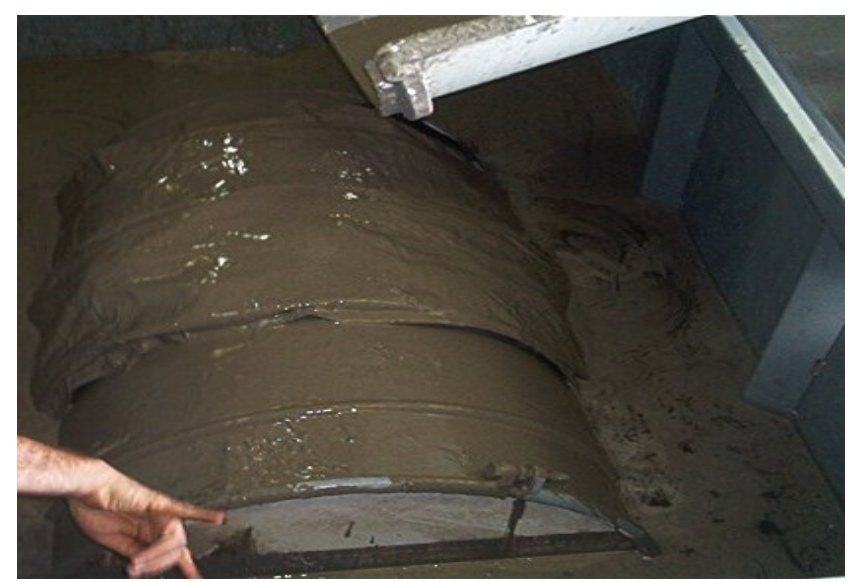

Beginning of the second stage of macro encapsulation of the sludge residue drum. The level indicator shows where the three inches of grout above the top of the drum will be after the pour (indicated by the black mark on the level indicator). 
Grout level at three inches above the top of the sludge residue container.
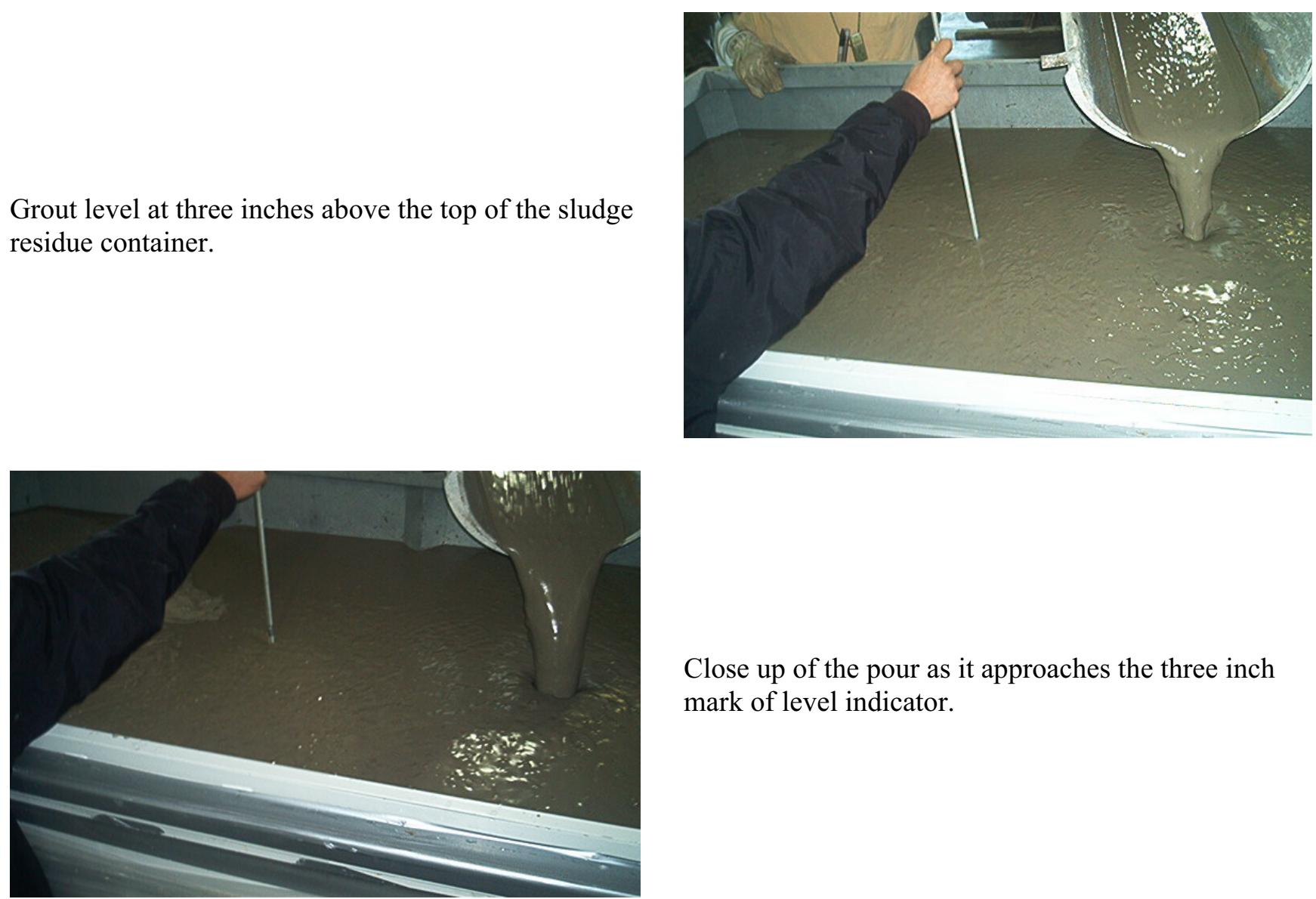

Close up of the pour as it approaches the three inch mark of level indicator. 
Appendix G

SFE-20 Soils Confirmation Sampling Results 
G-2 


\section{Appendix G}

\section{SFE-20 Soils Confirmation Sampling Results}

Table G-1. ESP-048-08 SFE-20 soil sample results for radionuclides.

\begin{tabular}{|c|c|c|c|c|c|c|c|}
\hline Radonuclide & Sample ID & Location & Grid & $\begin{array}{l}\text { Sample } \\
\text { Value } \\
(\mathrm{pCi} / \mathrm{g})\end{array}$ & $\begin{array}{c}\text { Val. } \\
\text { Flag }\end{array}$ & $\begin{array}{c}\text { Sample } \\
\text { Uncertainty } \\
(\mathrm{pCi} / \mathrm{g})\end{array}$ & L\&V Report \\
\hline Americium-241 & E0480800101RH & Pump Pit & $\# 3$ & 0.0122 & $\mathrm{U}$ & $6.11 \mathrm{E}-03$ & BAM-061-08 \\
\hline Americium-241 & E0480800201RH & Pump Pit & $\# 12$ & 0.0327 & & $1.02 \mathrm{E}-02$ & BAM-061-08 \\
\hline Americium-241 & E0480800301RH & Pump Pit & $\# 16$ & 0.242 & & $2.57 \mathrm{E}-02$ & BAM-061-08 \\
\hline Americium-241 & E0480800401RH & Pump Pit & $\# 18$ & 0.00126 & $\mathrm{U}$ & $4.73 \mathrm{E}-03$ & BAM-061-08 \\
\hline Americium-241 & E0480800501RH & Pump Pit & $\# 23$ & 0.0164 & $\mathrm{U}$ & $1.03 \mathrm{E}-02$ & BAM-061-08 \\
\hline Americium-241 & E0480800601RH & Tank Vault & $\# 8$ & 0.0384 & $\mathrm{~J}$ & $1.44 \mathrm{E}-02$ & BAM-061-08 \\
\hline Americium-241 & E0480800701RH & Tank Vault & $\# 9$ & 0.0363 & $\mathrm{~J}$ & $1.41 \mathrm{E}-02$ & BAM-061-08 \\
\hline Americium-241 & E0480800801RH & Tank Vault & $\# 15$ & 0.0379 & $\mathrm{~J}$ & $1.47 \mathrm{E}-02$ & BAM-061-08 \\
\hline Americium-241 & E0480800901RH & Tank Vault & $\# 24$ & 0.0134 & UJ & $5.44 \mathrm{E}-03$ & BAM-061-08 \\
\hline Americium-241 & E0480801001RH & Tank Vault & \#32 & 0.0356 & $\mathrm{U}$ & $1.43 \mathrm{E}-02$ & BAM-061-08 \\
\hline Americium-243 & E0480800101RH & Pump Pit & \#3 & 0.00033 & $\mathrm{U}$ & $1.50 \mathrm{E}-02$ & BAM-061-08 \\
\hline Americium-243 & E0480800201RH & Pump Pit & $\# 12$ & 0.00869 & $\mathrm{U}$ & 2.77E-02 & BAM-061-08 \\
\hline Americium-243 & E0480800301RH & Pump Pit & $\# 16$ & 0.0374 & $\mathrm{U}$ & $3.86 \mathrm{E}-02$ & BAM-061-08 \\
\hline Americium-243 & E0480800401RH & Pump Pit & $\# 18$ & 0.0286 & UJ & $1.32 \mathrm{E}-02$ & BAM-061-08 \\
\hline Americium-243 & E0480800501RH & Pump Pit & \#23 & 0.0294 & UJ & $1.28 \mathrm{E}-02$ & BAM-061-08 \\
\hline Americium-243 & E0480800601RH & Tank Vault & $\# 8$ & 0.0287 & UJ & $1.20 \mathrm{E}-02$ & BAM-061-08 \\
\hline Americium-243 & E0480800701RH & Tank Vault & $\# 9$ & 0.0127 & $\mathrm{U}$ & $1.01 \mathrm{E}-02$ & BAM-061-08 \\
\hline Americium-243 & E0480800801RH & Tank Vault & $\# 15$ & 0.0181 & $\mathrm{U}$ & $1.08 \mathrm{E}-02$ & BAM-061-08 \\
\hline Americium-243 & E0480800901RH & Tank Vault & $\# 24$ & 0.044 & $\mathrm{U}$ & $3.34 \mathrm{E}-02$ & BAM-061-08 \\
\hline Americium-243 & E0480801001RH & Tank Vault & \#32 & 0.0627 & UJ & $1.87 \mathrm{E}-02$ & BAM-061-08 \\
\hline Antimony-125 & E0480800101RH & Pump Pit & \#3 & -0.0577 & $\mathrm{U}$ & $1.53 \mathrm{E}-01$ & BAM-061-08 \\
\hline Antimony-125 & E0480800201RH & Pump Pit & $\# 12$ & 0.229 & $\mathrm{U}$ & 4.49E-01 & BAM-061-08 \\
\hline Antimony-125 & E0480800301RH & Pump Pit & $\# 16$ & -0.292 & $\mathrm{U}$ & $6.81 \mathrm{E}-01$ & BAM-061-08 \\
\hline Antimony-125 & E0480800401RH & Pump Pit & $\# 18$ & 0.242 & $\mathrm{U}$ & $2.12 \mathrm{E}-01$ & BAM-061-08 \\
\hline Antimony-125 & E0480800501RH & Pump Pit & \#23 & 0.0791 & $\mathrm{U}$ & $1.28 \mathrm{E}-01$ & BAM-061-08 \\
\hline Antimony-125 & E0480800601RH & Tank Vault & $\# 8$ & -1.39 & $\mathrm{U}$ & $7.43 \mathrm{E}-01$ & BAM-061-08 \\
\hline Antimony-125 & E0480800701RH & Tank Vault & \#9 & 0.597 & $\mathrm{U}$ & $3.98 \mathrm{E}-01$ & BAM-061-08 \\
\hline Antimony-125 & E0480800801RH & Tank Vault & $\# 15$ & 2.45 & UJ & $9.52 \mathrm{E}-01$ & BAM-061-08 \\
\hline Antimony-125 & E0480800901RH & Tank Vault & $\# 24$ & -0.174 & $\mathrm{U}$ & $2.95 \mathrm{E}-01$ & BAM-061-08 \\
\hline Antimony-125 & E0480801001RH & Tank Vault & \#32 & -0.367 & $\mathrm{U}$ & $3.49 \mathrm{E}-01$ & BAM-061-08 \\
\hline Carbon-14 & E0480800101RH & Pump Pit & $\# 3$ & -0.221 & $\mathrm{U}$ & $5.97 \mathrm{E}-01$ & BAM-061-08 \\
\hline Carbon-14 & E0480800201RH & Pump Pit & $\# 12$ & -0.792 & $\mathrm{U}$ & $5.86 \mathrm{E}-01$ & BAM-061-08 \\
\hline Carbon-14 & E0480800301RH & Pump Pit & $\# 16$ & -0.192 & $\mathrm{U}$ & $6.09 \mathrm{E}-01$ & BAM-061-08 \\
\hline Carbon-14 & E0480800401RH & Pump Pit & $\# 18$ & -0.559 & $\mathrm{U}$ & $5.81 \mathrm{E}-01$ & BAM-061-08 \\
\hline Carbon-14 & E0480800501RH & Pump Pit & $\# 23$ & -0.613 & $\mathrm{U}$ & $5.69 \mathrm{E}-01$ & BAM-061-08 \\
\hline Carbon-14 & E0480800601RH & Tank Vault & $\# 8$ & -0.602 & $\mathrm{U}$ & $5.91 \mathrm{E}-01$ & BAM-061-08 \\
\hline Carbon-14 & E0480800701RH & Tank Vault & $\# 9$ & 0.737 & $\mathrm{U}$ & $6.09 \mathrm{E}-01$ & BAM-061-08 \\
\hline Carbon-14 & E0480800801RH & Tank Vault & $\# 15$ & 0.917 & $\mathrm{U}$ & $5.94 \mathrm{E}-01$ & BAM-061-08 \\
\hline Carbon-14 & E0480800901RH & Tank Vault & $\# 24$ & -0.374 & $\mathrm{U}$ & $5.88 \mathrm{E}-01$ & BAM-061-08 \\
\hline Carbon-14 & E0480801001RH & Tank Vault & \#32 & -0.27 & $\mathrm{U}$ & $5.69 \mathrm{E}-01$ & BAM-061-08 \\
\hline Cerium-144 & E0480800101RH & Pump Pit & \#3 & 0.000028 & $\mathrm{U}$ & $5.12 \mathrm{E}-01$ & BAM-061-08 \\
\hline
\end{tabular}


Table G-1. (continued).

\begin{tabular}{|c|c|c|c|c|c|c|c|}
\hline Radonuclide & Sample ID & Location & Grid & $\begin{array}{c}\text { Sample } \\
\text { Value } \\
(\mathrm{pCi} / \mathrm{g})\end{array}$ & $\begin{array}{l}\text { Val. } \\
\text { Flag }\end{array}$ & $\begin{array}{c}\text { Sample } \\
\text { Uncertainty } \\
(\mathrm{pCi} / \mathrm{g})\end{array}$ & L\&V Report \\
\hline Cerium-144 & E0480800201RH & Pump Pit & $\# 12$ & -0.882 & $\mathrm{U}$ & $9.02 \mathrm{E}-01$ & BAM-061-08 \\
\hline Cerium-144 & E0480800301RH & Pump Pit & $\# 16$ & -0.283 & $\mathrm{U}$ & $9.19 \mathrm{E}-01$ & BAM-061-08 \\
\hline Cerium-144 & E0480800401RH & Pump Pit & $\# 18$ & -0.321 & $\mathrm{U}$ & 4.12E-01 & BAM-061-08 \\
\hline Cerium-144 & E0480800501RH & Pump Pit & $\# 23$ & -0.383 & $\mathrm{U}$ & $5.12 \mathrm{E}-01$ & BAM-061-08 \\
\hline Cerium-144 & E0480800601RH & Tank Vault & $\# 8$ & 0.503 & $\mathrm{U}$ & 8.82E-01 & BAM-061-08 \\
\hline Cerium-144 & E0480800701RH & Tank Vault & $\# 9$ & -0.289 & $\mathrm{U}$ & 4.39E-01 & BAM-061-08 \\
\hline Cerium-144 & E0480800801RH & Tank Vault & $\# 15$ & 0.552 & $\mathrm{U}$ & $1.02 \mathrm{E}+00$ & BAM-061-08 \\
\hline Cerium-144 & E0480800901RH & Tank Vault & $\# 24$ & 0.137 & $\mathrm{U}$ & $3.21 \mathrm{E}-01$ & BAM-061-08 \\
\hline Cerium-144 & E0480801001RH & Tank Vault & \#32 & 0.667 & $\mathrm{U}$ & 4.20E-01 & BAM-061-08 \\
\hline Cesium-134 & E0480800101RH & Pump Pit & $\# 3$ & 0.0335 & $\mathrm{U}$ & $3.20 \mathrm{E}-02$ & BAM-061-08 \\
\hline Cesium-134 & E0480800201RH & Pump Pit & $\# 12$ & 0.131 & $\mathrm{U}$ & $2.61 \mathrm{E}-01$ & BAM-061-08 \\
\hline Cesium-134 & E0480800301RH & Pump Pit & $\# 16$ & 0.142 & $\mathrm{U}$ & 7.74E-02 & BAM-061-08 \\
\hline Cesium-134 & E0480800401RH & Pump Pit & $\# 18$ & 0.0831 & $\mathrm{U}$ & $1.22 \mathrm{E}-01$ & BAM-061-08 \\
\hline Cesium-134 & E0480800501RH & Pump Pit & $\# 23$ & 0.0729 & UJ & $3.54 \mathrm{E}-02$ & BAM-061-08 \\
\hline Cesium-134 & E0480800601RH & Tank Vault & $\# 8$ & 0.0658 & UJ & $2.85 \mathrm{E}-02$ & BAM-061-08 \\
\hline Cesium-134 & E0480800701RH & Tank Vault & $\# 9$ & 0.0711 & UJ & $3.03 \mathrm{E}-02$ & BAM-061-08 \\
\hline Cesium-134 & E0480800801RH & Tank Vault & $\# 15$ & 0.12 & UJ & $5.53 \mathrm{E}-02$ & BAM-061-08 \\
\hline Cesium-134 & E0480800901RH & Tank Vault & $\# 24$ & 0.0592 & UJ & $2.36 \mathrm{E}-02$ & BAM-061-08 \\
\hline Cesium-134 & E0480801001RH & Tank Vault & \#32 & 0.0638 & $\mathrm{U}$ & 4.04E-02 & BAM-061-08 \\
\hline Cesium-137 & E0480800101RH & Pump Pit & $\# 3$ & 86.4 & & $4.55 \mathrm{E}+00$ & BAM-061-08 \\
\hline Cesium-137 & E0480800201RH & Pump Pit & $\# 12$ & 84.2 & & $3.65 \mathrm{E}+00$ & BAM-061-08 \\
\hline Cesium-137 & E0480800301RH & Pump Pit & $\# 16$ & 5730 & & $3.29 \mathrm{E}+02$ & BAM-061-08 \\
\hline Cesium-137 & E0480800401RH & Pump Pit & $\# 18$ & 8.64 & & $5.41 \mathrm{E}-01$ & BAM-061-08 \\
\hline Cesium-137 & E0480800501RH & Pump Pit & $\# 23$ & 17.5 & & $8.30 \mathrm{E}-01$ & BAM-061-08 \\
\hline Cesium-137 & E0480800601RH & Tank Vault & $\# 8$ & 3410 & & $1.31 \mathrm{E}+02$ & BAM-061-08 \\
\hline Cesium-137 & E0480800701RH & Tank Vault & $\# 9$ & 576 & & $2.54 \mathrm{E}+01$ & BAM-061-08 \\
\hline Cesium-137 & E0480800801RH & Tank Vault & $\# 15$ & 2720 & & $1.24 \mathrm{E}+02$ & BAM-061-08 \\
\hline Cesium-137 & E0480800901RH & Tank Vault & $\# 24$ & 414 & & $1.68 \mathrm{E}+01$ & BAM-061-08 \\
\hline Cesium-137 & E0480801001RH & Tank Vault & \#32 & 410 & & $2.13 \mathrm{E}+01$ & BAM-061-08 \\
\hline Cobalt- 60 & E0480800101RH & Pump Pit & \#3 & -0.0113 & $\mathrm{U}$ & $2.15 \mathrm{E}-02$ & BAM-061-08 \\
\hline Cobalt- 60 & E0480800201RH & Pump Pit & $\# 12$ & 0.0837 & $\mathrm{U}$ & $1.78 \mathrm{E}-01$ & BAM-061-08 \\
\hline Cobalt- 60 & E0480800301RH & Pump Pit & $\# 16$ & 0.719 & & 4.82E-02 & BAM-061-08 \\
\hline Cobalt- 60 & E0480800401RH & Pump Pit & $\# 18$ & -0.0296 & $\mathrm{U}$ & $8.24 \mathrm{E}-02$ & BAM-061-08 \\
\hline Cobalt- 60 & E0480800501RH & Pump Pit & $\# 23$ & 0.00752 & $\mathrm{U}$ & $2.36 \mathrm{E}-02$ & BAM-061-08 \\
\hline Cobalt- 60 & E0480800601RH & Tank Vault & $\# 8$ & 0.12 & & $3.23 \mathrm{E}-02$ & BAM-061-08 \\
\hline Cobalt- 60 & E0480800701RH & Tank Vault & $\# 9$ & 0.147 & & 4.76E-02 & BAM-061-08 \\
\hline Cobalt- 60 & E0480800801RH & Tank Vault & $\# 15$ & 0.272 & UJ & 7.03E-02 & BAM-061-08 \\
\hline Cobalt- 60 & E0480800901RH & Tank Vault & $\# 24$ & 0.0548 & $\mathrm{U}$ & $3.56 \mathrm{E}-02$ & BAM-061-08 \\
\hline Cobalt- 60 & E0480801001RH & Tank Vault & \#32 & 0.127 & UJ & $4.04 \mathrm{E}-02$ & BAM-061-08 \\
\hline Curium-242 & E0480800101RH & Pump Pit & $\# 3$ & 0.00237 & $\mathrm{U}$ & $2.37 \mathrm{E}-03$ & BAM-061-08 \\
\hline Curium-242 & E0480800201RH & Pump Pit & $\# 12$ & 0 & $\mathrm{U}$ & $3.61 \mathrm{E}-03$ & BAM-061-08 \\
\hline Curium-242 & E0480800301RH & Pump Pit & $\# 16$ & 0.00368 & $\mathrm{U}$ & $2.61 \mathrm{E}-03$ & BAM-061-08 \\
\hline Curium-242 & E0480800401RH & Pump Pit & $\# 18$ & 0 & $\mathrm{U}$ & 4.77E-03 & BAM-061-08 \\
\hline Curium-242 & E0480800501RH & Pump Pit & $\# 23$ & -0.00117 & $\mathrm{U}$ & $5.00 \mathrm{E}-03$ & BAM-061-08 \\
\hline Curium-242 & E0480800601RH & Tank Vault & $\# 8$ & -0.00121 & $\mathrm{U}$ & $5.18 \mathrm{E}-03$ & BAM-061-08 \\
\hline Curium-242 & E0480800701RH & Tank Vault & $\# 9$ & -0.0025 & $\mathrm{U}$ & $5.51 \mathrm{E}-03$ & BAM-061-08 \\
\hline Curium-242 & E0480800801RH & Tank Vault & $\# 15$ & 0.00483 & $\mathrm{U}$ & $4.84 \mathrm{E}-03$ & BAM-061-08 \\
\hline
\end{tabular}


Table G-1. (continued).

\begin{tabular}{|c|c|c|c|c|c|c|c|}
\hline Radonuclide & Sample ID & Location & Grid & $\begin{array}{l}\text { Sample } \\
\text { Value } \\
(\mathrm{pCi} / \mathrm{g})\end{array}$ & $\begin{array}{l}\text { Val. } \\
\text { Flag }\end{array}$ & $\begin{array}{c}\text { Sample } \\
\text { Uncertainty } \\
(\mathrm{pCi} / \mathrm{g})\end{array}$ & L\&V Report \\
\hline Curium-242 & E0480800901RH & Tank Vault & $\# 24$ & 0 & $\mathrm{U}$ & $1.44 \mathrm{E}-03$ & BAM-061-08 \\
\hline Curium-242 & E0480801001RH & Tank Vault & $\# 32$ & -0.00127 & $\mathrm{U}$ & $5.45 \mathrm{E}-03$ & BAM-061-08 \\
\hline Curium-243/244 & E0480800101RH & Pump Pit & $\# 3$ & 0.00221 & $\mathrm{U}$ & $3.83 \mathrm{E}-03$ & BAM-061-08 \\
\hline Curium-243/244 & E0480800201RH & Pump Pit & $\# 12$ & 0.00477 & $\mathrm{U}$ & $6.75 \mathrm{E}-03$ & BAM-061-08 \\
\hline Curium-243/244 & E0480800301RH & Pump Pit & $\# 16$ & 0.00344 & $\mathrm{U}$ & $2.44 \mathrm{E}-03$ & BAM-061-08 \\
\hline Curium-243/244 & E0480800401RH & Pump Pit & $\# 18$ & -0.00305 & $\mathrm{U}$ & $5.31 \mathrm{E}-03$ & BAM-061-08 \\
\hline Curium-243/244 & E0480800501RH & Pump Pit & $\# 23$ & -0.00988 & $\mathrm{U}$ & $5.64 \mathrm{E}-03$ & BAM-061-08 \\
\hline Curium-243/244 & E0480800601RH & Tank Vault & $\# 8$ & -0.00454 & $\mathrm{U}$ & $5.26 \mathrm{E}-03$ & BAM-061-08 \\
\hline Curium-243/244 & E0480800701RH & Tank Vault & $\# 9$ & 0.00628 & $\mathrm{U}$ & 7.24E-03 & BAM-061-08 \\
\hline Curium-243/244 & E0480800801RH & Tank Vault & $\# 15$ & 0.0106 & $\mathrm{U}$ & $9.57 \mathrm{E}-03$ & BAM-061-08 \\
\hline Curium-243/244 & E0480800901RH & Tank Vault & $\# 24$ & 0.00135 & $\mathrm{U}$ & $4.47 \mathrm{E}-03$ & BAM-061-08 \\
\hline Curium-243/244 & E0480801001RH & Tank Vault & \#32 & 0.000199 & $\mathrm{U}$ & $5.53 \mathrm{E}-03$ & BAM-061-08 \\
\hline Europium-152 & E0480800101RH & Pump Pit & $\# 3$ & -0.00985 & $\mathrm{U}$ & $1.57 \mathrm{E}-01$ & BAM-061-08 \\
\hline Europium-152 & E0480800201RH & Pump Pit & $\# 12$ & 0.435 & $\mathrm{U}$ & 4.07E-01 & BAM-061-08 \\
\hline Europium-152 & E0480800301RH & Pump Pit & $\# 16$ & 8.61 & & $6.76 \mathrm{E}-01$ & BAM-061-08 \\
\hline Europium-152 & E0480800401RH & Pump Pit & $\# 18$ & 0.302 & $\mathrm{U}$ & 2.27E-01 & BAM-061-08 \\
\hline Europium-152 & E0480800501RH & Pump Pit & $\# 23$ & -0.368 & $\mathrm{U}$ & $1.44 \mathrm{E}-01$ & BAM-061-08 \\
\hline Europium-152 & E0480800601RH & Tank Vault & $\# 8$ & -0.727 & $\mathrm{U}$ & $6.00 \mathrm{E}-01$ & BAM-061-08 \\
\hline Europium-152 & E0480800701RH & Tank Vault & $\# 9$ & 1.2 & UJ & $3.20 \mathrm{E}-01$ & BAM-061-08 \\
\hline Europium-152 & E0480800801RH & Tank Vault & $\# 15$ & 1.61 & UJ & 7.54E-01 & BAM-061-08 \\
\hline Europium-152 & E0480800901RH & Tank Vault & $\# 24$ & 1.01 & & $2.62 \mathrm{E}-01$ & BAM-061-08 \\
\hline Europium-152 & E0480801001RH & Tank Vault & $\# 32$ & 0.301 & $\mathrm{U}$ & $2.62 \mathrm{E}-01$ & BAM-061-08 \\
\hline Europium-154 & E0480800101RH & Pump Pit & $\# 3$ & 0.0628 & $\mathrm{U}$ & $6.75 \mathrm{E}-02$ & BAM-061-08 \\
\hline Europium-154 & E0480800201RH & Pump Pit & $\# 12$ & 0.596 & $\mathrm{U}$ & 5.33E-01 & BAM-061-08 \\
\hline Europium-154 & E0480800301RH & Pump Pit & $\# 16$ & 5.42 & & $3.68 \mathrm{E}-01$ & BAM-061-08 \\
\hline Europium-154 & E0480800401RH & Pump Pit & $\# 18$ & -0.31 & $\mathrm{U}$ & $2.47 \mathrm{E}-01$ & BAM-061-08 \\
\hline Europium-154 & E0480800501RH & Pump Pit & $\# 23$ & -0.0443 & $\mathrm{U}$ & $7.15 \mathrm{E}-02$ & BAM-061-08 \\
\hline Europium-154 & E0480800601RH & Tank Vault & $\# 8$ & 0.276 & UJ & 8.64E-02 & BAM-061-08 \\
\hline Europium-154 & E0480800701RH & Tank Vault & $\# 9$ & 0.721 & UJ & $1.14 \mathrm{E}-01$ & BAM-061-08 \\
\hline Europium-154 & E0480800801RH & Tank Vault & $\# 15$ & 1.99 & UJ & $2.62 \mathrm{E}-01$ & BAM-061-08 \\
\hline Europium-154 & E0480800901RH & Tank Vault & $\# 24$ & 0.702 & & $1.23 \mathrm{E}-01$ & BAM-061-08 \\
\hline Europium-154 & E0480801001RH & Tank Vault & \#32 & 0.252 & UJ & $9.60 \mathrm{E}-02$ & BAM-061-08 \\
\hline Europium-155 & E0480800101RH & Pump Pit & $\# 3$ & -0.336 & $\mathrm{U}$ & $3.03 \mathrm{E}-01$ & BAM-061-08 \\
\hline Europium-155 & E0480800201RH & Pump Pit & $\# 12$ & -0.177 & $\mathrm{U}$ & 4.73E-01 & BAM-061-08 \\
\hline Europium-155 & E0480800301RH & Pump Pit & $\# 16$ & -0.135 & $\mathrm{U}$ & 4.64E-01 & BAM-061-08 \\
\hline Europium-155 & E0480800401RH & Pump Pit & $\# 18$ & 0.0278 & $\mathrm{U}$ & $2.11 \mathrm{E}-01$ & BAM-061-08 \\
\hline Europium-155 & E0480800501RH & Pump Pit & $\# 23$ & 0.301 & $\mathrm{U}$ & $3.33 \mathrm{E}-01$ & BAM-061-08 \\
\hline Europium-155 & E0480800601RH & Tank Vault & $\# 8$ & -0.503 & $\mathrm{U}$ & $4.59 \mathrm{E}-01$ & BAM-061-08 \\
\hline Europium-155 & E0480800701RH & Tank Vault & $\# 9$ & 0.0789 & $\mathrm{U}$ & $2.22 \mathrm{E}-01$ & BAM-061-08 \\
\hline Europium-155 & E0480800801RH & Tank Vault & $\# 15$ & -0.245 & $\mathrm{U}$ & $5.02 \mathrm{E}-01$ & BAM-061-08 \\
\hline Europium-155 & E0480800901RH & Tank Vault & $\# 24$ & -0.0926 & $\mathrm{U}$ & $1.62 \mathrm{E}-01$ & BAM-061-08 \\
\hline Europium-155 & E0480801001RH & Tank Vault & \#32 & 0.0399 & $\mathrm{U}$ & $2.06 \mathrm{E}-01$ & BAM-061-08 \\
\hline Manganese-54 & E0480800101RH & Pump Pit & $\# 3$ & 0.0202 & $\mathrm{U}$ & $2.62 \mathrm{E}-02$ & BAM-061-08 \\
\hline Manganese-54 & E0480800201RH & Pump Pit & $\# 12$ & -0.332 & $\mathrm{U}$ & $2.12 \mathrm{E}-01$ & BAM-061-08 \\
\hline Manganese-54 & E0480800301RH & Pump Pit & $\# 16$ & 0.0994 & $\mathrm{U}$ & $5.71 \mathrm{E}-02$ & BAM-061-08 \\
\hline Manganese-54 & E0480800401RH & Pump Pit & $\# 18$ & -0.0393 & $\mathrm{U}$ & $9.83 \mathrm{E}-02$ & BAM-061-08 \\
\hline Manganese-54 & E0480800501RH & Pump Pit & $\# 23$ & 0.0372 & $\mathrm{U}$ & $2.60 \mathrm{E}-02$ & BAM-061-08 \\
\hline
\end{tabular}


Table G-1. (continued).

\begin{tabular}{|c|c|c|c|c|c|c|c|}
\hline Radonuclide & Sample ID & Location & Grid & $\begin{array}{c}\text { Sample } \\
\text { Value } \\
(\mathrm{pCi} / \mathrm{g})\end{array}$ & $\begin{array}{l}\text { Val. } \\
\text { Flag }\end{array}$ & $\begin{array}{c}\text { Sample } \\
\text { Uncertainty } \\
(\mathrm{pCi} / \mathrm{g})\end{array}$ & L\&V Report \\
\hline Manganese-54 & E0480800601RH & Tank Vault & $\# 8$ & 0.0275 & $\mathrm{U}$ & $2.26 \mathrm{E}-02$ & BAM-061-08 \\
\hline Manganese-54 & E0480800701RH & Tank Vault & $\# 9$ & -0.00803 & $\mathrm{U}$ & $2.38 \mathrm{E}-02$ & BAM-061-08 \\
\hline Manganese-54 & E0480800801RH & Tank Vault & $\# 15$ & -0.0606 & $\mathrm{U}$ & 4.48E-02 & BAM-061-08 \\
\hline Manganese-54 & E0480800901RH & Tank Vault & $\# 24$ & -0.0246 & $\mathrm{U}$ & $2.11 \mathrm{E}-02$ & BAM-061-08 \\
\hline Manganese-54 & E0480801001RH & Tank Vault & $\# 32$ & 0.067 & UJ & $2.47 \mathrm{E}-02$ & BAM-061-08 \\
\hline Plutonium-238 & E0480800101RH & Pump Pit & $\# 3$ & 0.0502 & & $1.65 \mathrm{E}-02$ & BAM-061-08 \\
\hline Plutonium-238 & E0480800201RH & Pump Pit & $\# 12$ & 0.083 & & $2.08 \mathrm{E}-02$ & BAM-061-08 \\
\hline Plutonium-238 & E0480800301RH & Pump Pit & $\# 16$ & 0.716 & & 7.08E-02 & BAM-061-08 \\
\hline Plutonium-238 & E0480800401RH & Pump Pit & $\# 18$ & 0.00904 & $\mathrm{U}$ & $9.19 \mathrm{E}-03$ & BAM-061-08 \\
\hline Plutonium-238 & E0480800501RH & Pump Pit & $\# 23$ & 0.00957 & $\mathrm{U}$ & 7.49E-03 & BAM-061-08 \\
\hline Plutonium-238 & E0480800601RH & Tank Vault & $\# 8$ & 0.0766 & & $1.99 \mathrm{E}-02$ & BAM-061-08 \\
\hline Plutonium-238 & E0480800701RH & Tank Vault & $\# 9$ & 0.0925 & & 2.19E-02 & BAM-061-08 \\
\hline Plutonium-238 & E0480800801RH & Tank Vault & $\# 15$ & 0.215 & & $3.29 \mathrm{E}-02$ & BAM-061-08 \\
\hline Plutonium-238 & E0480800901RH & Tank Vault & $\# 24$ & 0.0452 & $\mathrm{~J}$ & $1.57 \mathrm{E}-02$ & BAM-061-08 \\
\hline Plutonium-238 & E0480801001RH & Tank Vault & \#32 & 0.125 & & $2.45 \mathrm{E}-02$ & BAM-061-08 \\
\hline Plutonium-239/240 & E0480800101RH & Pump Pit & $\# 3$ & 0.0333 & $\mathrm{~J}$ & $1.28 \mathrm{E}-02$ & BAM-061-08 \\
\hline Plutonium-239/240 & E0480800201RH & Pump Pit & $\# 12$ & 0.115 & & $2.30 \mathrm{E}-02$ & BAM-061-08 \\
\hline Plutonium-239/240 & E0480800301RH & Pump Pit & $\# 16$ & 2.42 & & $1.75 \mathrm{E}-01$ & BAM-061-08 \\
\hline Plutonium-239/240 & E0480800401RH & Pump Pit & $\# 18$ & 0.0175 & $\mathrm{U}$ & $9.98 \mathrm{E}-03$ & BAM-061-08 \\
\hline Plutonium-239/240 & E0480800501RH & Pump Pit & $\# 23$ & 0.0777 & & $1.88 \mathrm{E}-02$ & BAM-061-08 \\
\hline Plutonium-239/240 & E0480800601RH & Tank Vault & $\# 8$ & 0.387 & & 4.54E-02 & BAM-061-08 \\
\hline Plutonium-239/240 & E0480800701RH & Tank Vault & $\# 9$ & 0.178 & & $2.95 \mathrm{E}-02$ & BAM-061-08 \\
\hline Plutonium-239/240 & E0480800801RH & Tank Vault & $\# 15$ & 0.891 & & 7.92E-02 & BAM-061-08 \\
\hline Plutonium-239/240 & E0480800901RH & Tank Vault & $\# 24$ & 0.161 & & $2.88 \mathrm{E}-02$ & BAM-061-08 \\
\hline Plutonium-239/240 & E0480801001RH & Tank Vault & $\# 32$ & 0.291 & & $3.87 \mathrm{E}-02$ & BAM-061-08 \\
\hline Plutonium-241 & E0480800101RH & Pump Pit & $\# 3$ & -0.058 & $\mathrm{U}$ & $1.58 \mathrm{E}-01$ & BAM-061-08 \\
\hline Plutonium-241 & E0480800201RH & Pump Pit & $\# 12$ & 0.346 & UJ & $1.49 \mathrm{E}-01$ & BAM-061-08 \\
\hline Plutonium-241 & E0480800301RH & Pump Pit & $\# 16$ & 0.789 & & $1.95 \mathrm{E}-01$ & BAM-061-08 \\
\hline Plutonium-241 & E0480800401RH & Pump Pit & $\# 18$ & -0.315 & $\mathrm{U}$ & $1.43 \mathrm{E}-01$ & BAM-061-08 \\
\hline Plutonium-241 & E0480800501RH & Pump Pit & $\# 23$ & -0.613 & $\mathrm{U}$ & $1.32 \mathrm{E}-01$ & BAM-061-08 \\
\hline Plutonium-241 & E0480800601RH & Tank Vault & $\# 8$ & -0.295 & $\mathrm{U}$ & $1.66 \mathrm{E}-01$ & BAM-061-08 \\
\hline Plutonium-241 & E0480800701RH & Tank Vault & $\# 9$ & -0.7 & $\mathrm{U}$ & $1.61 \mathrm{E}-01$ & BAM-061-08 \\
\hline Plutonium-241 & E0480800801RH & Tank Vault & $\# 15$ & -0.616 & $\mathrm{U}$ & $1.78 \mathrm{E}-01$ & BAM-061-08 \\
\hline Plutonium-241 & E0480800901RH & Tank Vault & $\# 24$ & -0.726 & $\mathrm{U}$ & $1.35 \mathrm{E}-01$ & BAM-061-08 \\
\hline Plutonium-241 & E0480801001RH & Tank Vault & $\# 32$ & -0.753 & $\mathrm{U}$ & $2.23 \mathrm{E}-01$ & BAM-061-08 \\
\hline Ruthenium-106 & E0480800101RH & Pump Pit & $\# 3$ & 0.219 & $\mathrm{U}$ & $3.56 \mathrm{E}-01$ & BAM-061-08 \\
\hline Ruthenium-106 & E0480800201RH & Pump Pit & $\# 12$ & 1.45 & $\mathrm{U}$ & $1.84 \mathrm{E}+00$ & BAM-061-08 \\
\hline Ruthenium-106 & E0480800301RH & Pump Pit & $\# 16$ & 0.516 & $\mathrm{U}$ & $1.32 \mathrm{E}+00$ & BAM-061-08 \\
\hline Ruthenium-106 & E0480800401RH & Pump Pit & $\# 18$ & -0.828 & $\mathrm{U}$ & $8.21 \mathrm{E}-01$ & BAM-061-08 \\
\hline Ruthenium-106 & E0480800501RH & Pump Pit & $\# 23$ & -0.254 & $\mathrm{U}$ & $3.15 \mathrm{E}-01$ & BAM-061-08 \\
\hline Ruthenium-106 & E0480800601RH & Tank Vault & $\# 8$ & -0.434 & $\mathrm{U}$ & $1.41 \mathrm{E}+00$ & BAM-061-08 \\
\hline Ruthenium-106 & E0480800701RH & Tank Vault & $\# 9$ & -0.89 & $\mathrm{U}$ & $7.21 \mathrm{E}-01$ & BAM-061-08 \\
\hline Ruthenium-106 & E0480800801RH & Tank Vault & $\# 15$ & -1.31 & $\mathrm{U}$ & $1.79 \mathrm{E}+00$ & BAM-061-08 \\
\hline Ruthenium-106 & E0480800901RH & Tank Vault & $\# 24$ & 0.182 & $\mathrm{U}$ & $5.59 \mathrm{E}-01$ & BAM-061-08 \\
\hline Ruthenium-106 & E0480801001RH & Tank Vault & $\# 32$ & 0.201 & $\mathrm{U}$ & $6.10 \mathrm{E}-01$ & BAM-061-08 \\
\hline Silver-108m & E0480800101RH & Pump Pit & $\# 3$ & 0.00679 & $\mathrm{U}$ & $5.52 \mathrm{E}-02$ & BAM-061-08 \\
\hline Silver-108m & E0480800201RH & Pump Pit & $\# 12$ & -0.0487 & $\mathrm{U}$ & $1.62 \mathrm{E}-01$ & BAM-061-08 \\
\hline
\end{tabular}


Table G-1. (continued).

\begin{tabular}{|c|c|c|c|c|c|c|c|}
\hline Radonuclide & Sample ID & Location & Grid & $\begin{array}{l}\text { Sample } \\
\text { Value } \\
(\mathrm{pCi} / \mathrm{g})\end{array}$ & $\begin{array}{l}\text { Val. } \\
\text { Flag }\end{array}$ & $\begin{array}{c}\text { Sample } \\
\text { Uncertainty } \\
(\mathrm{pCi} / \mathrm{g})\end{array}$ & L\&V Report \\
\hline Silver-108m & E0480800301RH & Pump Pit & $\# 16$ & 0.185 & $\mathrm{U}$ & $2.49 \mathrm{E}-01$ & BAM-061-08 \\
\hline Silver-108m & E0480800401RH & Pump Pit & $\# 18$ & 0.00794 & $\mathrm{U}$ & $7.61 \mathrm{E}-02$ & BAM-061-08 \\
\hline Silver-108m & E0480800501RH & Pump Pit & \#23 & 0.0343 & $\mathrm{U}$ & 4.63E-02 & BAM-061-08 \\
\hline Silver-108m & E0480800601RH & Tank Vault & $\# 8$ & 0.278 & $\mathrm{U}$ & $2.71 \mathrm{E}-01$ & BAM-061-08 \\
\hline Silver-108m & E0480800701RH & Tank Vault & $\# 9$ & -0.0826 & $\mathrm{U}$ & $1.45 \mathrm{E}-01$ & BAM-061-08 \\
\hline Silver-108m & E0480800801RH & Tank Vault & $\# 15$ & -0.481 & $\mathrm{U}$ & $3.48 \mathrm{E}-01$ & BAM-061-08 \\
\hline Silver-108m & E0480800901RH & Tank Vault & $\# 24$ & -0.12 & $\mathrm{U}$ & $1.08 \mathrm{E}-01$ & BAM-061-08 \\
\hline Silver-108m & E0480801001RH & Tank Vault & \#32 & -0.0557 & $\mathrm{U}$ & $1.27 \mathrm{E}-01$ & BAM-061-08 \\
\hline Silver-110m & E0480800101RH & Pump Pit & $\# 3$ & 10 & UJ & $5.42 \mathrm{E}-01$ & BAM-061-08 \\
\hline Silver-110m & E0480800201RH & Pump Pit & $\# 12$ & 5.8 & UJ & $3.47 \mathrm{E}-01$ & BAM-061-08 \\
\hline Silver-110m & E0480800301RH & Pump Pit & $\# 16$ & 456 & UJ & $2.63 \mathrm{E}+01$ & BAM-061-08 \\
\hline Silver-110m & E0480800401RH & Pump Pit & $\# 18$ & 0.143 & $\mathrm{U}$ & $1.06 \mathrm{E}-01$ & BAM-061-08 \\
\hline Silver-110m & E0480800501RH & Pump Pit & $\# 23$ & 1.29 & UJ & 8.08E-02 & BAM-061-08 \\
\hline Silver-110m & E0480800601RH & Tank Vault & $\# 8$ & 20.6 & UJ & $8.48 \mathrm{E}-01$ & BAM-061-08 \\
\hline Silver-110m & E0480800701RH & Tank Vault & $\# 9$ & 2.23 & UJ & $1.49 \mathrm{E}-01$ & BAM-061-08 \\
\hline Silver-110m & E0480800801RH & Tank Vault & \#15 & 607 & UJ & $2.82 \mathrm{E}+01$ & BAM-061-08 \\
\hline Silver-110m & E0480800901RH & Tank Vault & $\# 24$ & 5.92 & UJ & $2.69 \mathrm{E}-01$ & BAM-061-08 \\
\hline Silver-110m & E0480801001RH & Tank Vault & \#32 & 2.34 & UJ & $1.63 \mathrm{E}-01$ & BAM-061-08 \\
\hline Strontium-90 & E0480800101RH & Pump Pit & $\# 3$ & 4690 & & $4.76 \mathrm{E}+02$ & BAM-061-08 \\
\hline Strontium-90 & E0480800201RH & Pump Pit & $\# 12$ & 16400 & & $1.66 \mathrm{E}+03$ & BAM-061-08 \\
\hline Strontium-90 & E0480800301RH & Pump Pit & \#16 & 9390 & & $9.55 \mathrm{E}+02$ & BAM-061-08 \\
\hline Strontium-90 & E0480800401RH & Pump Pit & $\# 18$ & 3770 & & $3.83 \mathrm{E}+02$ & BAM-061-08 \\
\hline Strontium-90 & E0480800501RH & Pump Pit & $\# 23$ & 4690 & & $4.77 \mathrm{E}+02$ & BAM-061-08 \\
\hline Strontium-90 & E0480800601RH & Tank Vault & $\# 8$ & 2320 & & $2.36 \mathrm{E}+02$ & BAM-061-08 \\
\hline Strontium-90 & E0480800701RH & Tank Vault & $\# 9$ & 605 & & $6.13 \mathrm{E}+01$ & BAM-061-08 \\
\hline Strontium-90 & E0480800801RH & Tank Vault & $\# 15$ & 766 & & $7.78 \mathrm{E}+01$ & BAM-061-08 \\
\hline Strontium-90 & E0480800901RH & Tank Vault & $\# 24$ & 264 & & $2.69 \mathrm{E}+01$ & BAM-061-08 \\
\hline Strontium-90 & E0480801001RH & Tank Vault & \#32 & 909 & & $9.24 \mathrm{E}+01$ & BAM-061-08 \\
\hline Technetium-99 & E0480800101RH & Pump Pit & \#3 & 0.276 & $\mathrm{U}$ & $2.39 \mathrm{E}-01$ & BAM-061-08 \\
\hline Technetium-99 & E0480800201RH & Pump Pit & $\# 12$ & 0.126 & $\mathrm{U}$ & 2.13E-01 & BAM-061-08 \\
\hline Technetium-99 & E0480800301RH & Pump Pit & $\# 16$ & 1.67 & & $3.81 \mathrm{E}-01$ & BAM-061-08 \\
\hline Technetium-99 & E0480800401RH & Pump Pit & $\# 18$ & 0.504 & UJ & 2.29E-01 & BAM-061-08 \\
\hline Technetium-99 & E0480800501RH & Pump Pit & \#23 & 0.706 & UJ & 2.34E-01 & BAM-061-08 \\
\hline Technetium-99 & E0480800601RH & Tank Vault & $\# 8$ & 0.408 & $\mathrm{U}$ & $3.25 \mathrm{E}-01$ & BAM-061-08 \\
\hline Technetium-99 & E0480800701RH & Tank Vault & $\# 9$ & 0.35 & $\mathrm{U}$ & $2.32 \mathrm{E}-01$ & BAM-061-08 \\
\hline Technetium-99 & E0480800801RH & Tank Vault & $\# 15$ & 0.645 & UJ & 2.22E-01 & BAM-061-08 \\
\hline Technetium-99 & E0480800901RH & Tank Vault & $\# 24$ & 0.104 & $\mathrm{U}$ & $2.25 \mathrm{E}-01$ & BAM-061-08 \\
\hline Technetium-99 & E0480801001RH & Tank Vault & \#32 & 0.498 & UJ & $2.26 \mathrm{E}-01$ & BAM-061-08 \\
\hline Tritium & E0480800101RH & Pump Pit & $\# 3$ & 5.43 & $\mathrm{U}$ & $3.59 \mathrm{E}+00$ & BAM-061-08 \\
\hline Tritium & E0480800201RH & Pump Pit & $\# 12$ & 8.31 & UJ & $3.77 \mathrm{E}+00$ & BAM-061-08 \\
\hline Tritium & E0480800301RH & Pump Pit & $\# 16$ & 3.65 & $\mathrm{U}$ & $3.39 \mathrm{E}+00$ & BAM-061-08 \\
\hline Tritium & E0480800401RH & Pump Pit & $\# 18$ & 9.01 & UJ & $3.86 \mathrm{E}+00$ & BAM-061-08 \\
\hline Tritium & E0480800501RH & Pump Pit & \#23 & 5.43 & $\mathrm{U}$ & $3.59 \mathrm{E}+00$ & BAM-061-08 \\
\hline Tritium & E0480800601RH & Tank Vault & $\# 8$ & 9.85 & UJ & $3.97 \mathrm{E}+00$ & BAM-061-08 \\
\hline Tritium & E0480800701RH & Tank Vault & $\# 9$ & 7.8 & UJ & $3.83 \mathrm{E}+00$ & BAM-061-08 \\
\hline Tritium & E0480800801RH & Tank Vault & \#15 & 3.61 & $\mathrm{U}$ & $3.35 \mathrm{E}+00$ & BAM-061-08 \\
\hline Tritium & E0480800901RH & Tank Vault & \#24 & 6.58 & $\mathrm{U}$ & $3.52 \mathrm{E}+00$ & BAM-061-08 \\
\hline
\end{tabular}


Table G-1. (continued).

\begin{tabular}{|c|c|c|c|c|c|c|c|}
\hline Radonuclide & Sample ID & Location & Grid & $\begin{array}{l}\text { Sample } \\
\text { Value } \\
(\mathrm{pCi} / \mathrm{g})\end{array}$ & $\begin{array}{l}\text { Val. } \\
\text { Flag }\end{array}$ & $\begin{array}{c}\text { Sample } \\
\text { Uncertainty } \\
(\mathrm{pCi} / \mathrm{g})\end{array}$ & L\&V Report \\
\hline Tritium & E0480801001RH & Tank Vault & $\# 32$ & 5.29 & $\mathrm{U}$ & $3.15 \mathrm{E}+00$ & BAM-061-08 \\
\hline Uranium-233/234 & E0480800101RH & Pump Pit & $\# 3$ & 1.09 & & $9.58 \mathrm{E}-02$ & BAM-061-08 \\
\hline Uranium-233/234 & E0480800201RH & Pump Pit & $\# 12$ & 2.16 & & $1.68 \mathrm{E}-01$ & BAM-061-08 \\
\hline Uranium-233/234 & E0480800301RH & Pump Pit & $\# 16$ & 2.21 & & $1.67 \mathrm{E}-01$ & BAM-061-08 \\
\hline Uranium-233/234 & E0480800401RH & Pump Pit & $\# 18$ & 1.05 & & $9.25 \mathrm{E}-02$ & BAM-061-08 \\
\hline Uranium-233/234 & E0480800501RH & Pump Pit & $\# 23$ & 1.25 & & $1.05 \mathrm{E}-01$ & BAM-061-08 \\
\hline Uranium-233/234 & E0480800601RH & Tank Vault & $\# 8$ & 1.36 & & $1.13 \mathrm{E}-01$ & BAM-061-08 \\
\hline Uranium-233/234 & E0480800701RH & Tank Vault & $\# 9$ & 1.2 & & $1.02 \mathrm{E}-01$ & BAM-061-08 \\
\hline Uranium-233/234 & E0480800801RH & Tank Vault & $\# 15$ & 1.23 & & $1.05 \mathrm{E}-01$ & BAM-061-08 \\
\hline Uranium-233/234 & E0480800901RH & Tank Vault & $\# 24$ & 1.11 & & $9.69 \mathrm{E}-02$ & BAM-061-08 \\
\hline Uranium-233/234 & E0480801001RH & Tank Vault & \#32 & 1.11 & & $9.75 \mathrm{E}-02$ & BAM-061-08 \\
\hline Uranium-235 & E0480800101RH & Pump Pit & $\# 3$ & 0.111 & & $2.58 \mathrm{E}-02$ & BAM-061-08 \\
\hline Uranium-235 & E0480800201RH & Pump Pit & $\# 12$ & 0.181 & & $3.50 \mathrm{E}-02$ & BAM-061-08 \\
\hline Uranium-235 & E0480800301RH & Pump Pit & $\# 16$ & 0.174 & & $3.30 \mathrm{E}-02$ & BAM-061-08 \\
\hline Uranium-235 & E0480800401RH & Pump Pit & $\# 18$ & 0.0778 & & $2.15 \mathrm{E}-02$ & BAM-061-08 \\
\hline Uranium-235 & E0480800501RH & Pump Pit & $\# 23$ & 0.0967 & & $2.35 \mathrm{E}-02$ & BAM-061-08 \\
\hline Uranium-235 & E0480800601RH & Tank Vault & $\# 8$ & 0.0604 & & $1.98 \mathrm{E}-02$ & BAM-061-08 \\
\hline Uranium-235 & E0480800701RH & Tank Vault & $\# 9$ & 0.043 & $\mathrm{~J}$ & $1.54 \mathrm{E}-02$ & BAM-061-08 \\
\hline Uranium-235 & E0480800801RH & Tank Vault & $\# 15$ & 0.0717 & & 2.03E-02 & BAM-061-08 \\
\hline Uranium-235 & E0480800901RH & Tank Vault & $\# 24$ & 0.0652 & & $1.92 \mathrm{E}-02$ & BAM-061-08 \\
\hline Uranium-235 & E0480801001RH & Tank Vault & \#32 & 0.0503 & $\mathrm{~J}$ & $1.70 \mathrm{E}-02$ & BAM-061-08 \\
\hline Uranium-238 & E0480800101RH & Pump Pit & $\# 3$ & 1.08 & & $9.55 \mathrm{E}-02$ & BAM-061-08 \\
\hline Uranium-238 & E0480800201RH & Pump Pit & $\# 12$ & 1.05 & & $9.58 \mathrm{E}-02$ & BAM-061-08 \\
\hline Uranium-238 & E0480800301RH & Pump Pit & $\# 16$ & 1.1 & & $9.70 \mathrm{E}-02$ & BAM-061-08 \\
\hline Uranium-238 & E0480800401RH & Pump Pit & $\# 18$ & 1.11 & & $9.62 \mathrm{E}-02$ & BAM-061-08 \\
\hline Uranium-238 & E0480800501RH & Pump Pit & $\# 23$ & 1.2 & & $1.02 \mathrm{E}-01$ & BAM-061-08 \\
\hline Uranium-238 & E0480800601RH & Tank Vault & $\# 8$ & 1.27 & & $1.08 \mathrm{E}-01$ & BAM-061-08 \\
\hline Uranium-238 & E0480800701RH & Tank Vault & $\# 9$ & 1.34 & & $1.11 \mathrm{E}-01$ & BAM-061-08 \\
\hline Uranium-238 & E0480800801RH & Tank Vault & $\# 15$ & 1.1 & & $9.64 \mathrm{E}-02$ & BAM-061-08 \\
\hline Uranium-238 & E0480800901RH & Tank Vault & $\# 24$ & 0.96 & & 8.68E-02 & BAM-061-08 \\
\hline Uranium-238 & E0480801001RH & Tank Vault & \#32 & 1.06 & & $9.47 \mathrm{E}-02$ & BAM-061-08 \\
\hline Zinc-65 & E0480800101RH & Pump Pit & $\# 3$ & -0.00563 & $\mathrm{U}$ & $6.24 \mathrm{E}-02$ & BAM-061-08 \\
\hline Zinc-65 & E0480800201RH & Pump Pit & $\# 12$ & -0.302 & $\mathrm{U}$ & 4.37E-01 & BAM-061-08 \\
\hline Zinc-65 & E0480800301RH & Pump Pit & $\# 16$ & 2.11 & UJ & $1.48 \mathrm{E}-01$ & BAM-061-08 \\
\hline Zinc- 65 & E0480800401RH & Pump Pit & $\# 18$ & -0.097 & $\mathrm{U}$ & $1.99 \mathrm{E}-01$ & BAM-061-08 \\
\hline Zinc-65 & E0480800501RH & Pump Pit & $\# 23$ & 0.0354 & $\mathrm{U}$ & $6.03 \mathrm{E}-02$ & BAM-061-08 \\
\hline Zinc-65 & E0480800601RH & Tank Vault & $\# 8$ & 0.000731 & $\mathrm{U}$ & $9.19 \mathrm{E}-02$ & BAM-061-08 \\
\hline Zinc-65 & E0480800701RH & Tank Vault & $\# 9$ & 0.186 & & $5.94 \mathrm{E}-02$ & BAM-061-08 \\
\hline Zinc-65 & E0480800801RH & Tank Vault & $\# 15$ & -0.103 & $\mathrm{U}$ & $1.17 \mathrm{E}-01$ & BAM-061-08 \\
\hline Zinc-65 & E0480800901RH & Tank Vault & $\# 24$ & 0.0845 & $\mathrm{U}$ & 8.06E-02 & BAM-061-08 \\
\hline Zinc-65 & E0480801001RH & Tank Vault & \#32 & -0.0406 & $\mathrm{U}$ & $6.58 \mathrm{E}-02$ & BAM-061-08 \\
\hline \multicolumn{8}{|c|}{ Explanation of Validation Flags: } \\
\hline \multicolumn{8}{|c|}{$\mathrm{U}=$ The radioanalytical result was not statistically positive at the $95 \%$ confidence interval and/or the result was below its MDC. } \\
\hline \multicolumn{8}{|c|}{$\begin{array}{l}\mathrm{J}=\text { The radioanalytical result was statistically positive at the } 95 \% \text { confidence interval and is above the MDC. However the result is } \\
\text { questionable and should therefore only be considered an estimate of the true concentration. }\end{array}$} \\
\hline $\mathrm{UJ}=$ The result is & hly questionable due t & alytical and/or & sectos & 1. & . & . 1 & ouraged \\
\hline
\end{tabular}


Table G-2. ESP-048-08 SFE-20 soil sample results for PCBs.

\begin{tabular}{|c|c|c|c|c|c|c|c|}
\hline Compound & $\begin{array}{c}\text { Field Sample } \\
\text { Number }\end{array}$ & Location & Grid & $\begin{array}{c}\text { Sample } \\
\text { Result } \\
(\mu \mathrm{g} / \mathrm{kg})\end{array}$ & $\begin{array}{l}\text { Result } \\
\text { Qual. }\end{array}$ & $\begin{array}{l}\text { Val. } \\
\text { Flag }\end{array}$ & L\&V Report \\
\hline Aroclor-1016 & E04808001013A & Pump Pit & $\# 3$ & 3.52 & $\mathrm{U}$ & & HCJ-165-08 \\
\hline Aroclor-1016 & E04808002013A & Pump Pit & $\# 12$ & 3.57 & $\mathrm{U}$ & & HCJ-165-08 \\
\hline Aroclor-1016 & E04808003013A & Pump Pit & $\# 16$ & 3.66 & $\mathrm{U}$ & & HCJ-165-08 \\
\hline Aroclor-1016 & E04808004013A & Pump Pit & $\# 18$ & 3.52 & $\mathrm{U}$ & & HCJ-165-08 \\
\hline Aroclor-1016 & E04808005013A & Pump Pit & $\# 23$ & 3.47 & $\mathrm{U}$ & & HCJ-165-08 \\
\hline Aroclor-1016 & E04808006013A & Tank Vault & $\# 8$ & 3.67 & $\mathrm{U}$ & & HCJ-165-08 \\
\hline Aroclor-1016 & E04808007013A & Tank Vault & $\# 9$ & 3.62 & $\mathrm{U}$ & & HCJ-165-08 \\
\hline Aroclor-1016 & E04808008013A & Tank Vault & $\# 15$ & 3.55 & $\mathrm{U}$ & & HCJ-165-08 \\
\hline Aroclor-1016 & E04808009013A & Tank Vault & $\# 24$ & 3.66 & $\mathrm{U}$ & & HCJ-165-08 \\
\hline Aroclor-1016 & E04808010013A & Tank Vault & $\# 32$ & 3.57 & $\mathrm{U}$ & & HCJ-165-08 \\
\hline Aroclor-1221 & E04808001013A & Pump Pit & $\# 3$ & 3.52 & $\mathrm{U}$ & & HCJ-165-08 \\
\hline Aroclor-1221 & E04808002013A & Pump Pit & $\# 12$ & 3.57 & $\mathrm{U}$ & & HCJ-165-08 \\
\hline Aroclor-1221 & E04808003013A & Pump Pit & $\# 16$ & 3.66 & $\mathrm{U}$ & & HCJ-165-08 \\
\hline Aroclor-1221 & E04808004013A & Pump Pit & $\# 18$ & 3.52 & $\mathrm{U}$ & & HCJ-165-08 \\
\hline Aroclor-1221 & E04808005013A & Pump Pit & $\# 23$ & 3.47 & $\mathrm{U}$ & & HCJ-165-08 \\
\hline Aroclor-1221 & E04808006013A & Tank Vault & $\# 8$ & 3.67 & $\mathrm{U}$ & & HCJ-165-08 \\
\hline Aroclor-1221 & E04808007013A & Tank Vault & $\# 9$ & 3.62 & $\mathrm{U}$ & & HCJ-165-08 \\
\hline Aroclor-1221 & E04808008013A & Tank Vault & $\# 15$ & 3.55 & $\mathrm{U}$ & & HCJ-165-08 \\
\hline Aroclor-1221 & E04808009013A & Tank Vault & $\# 24$ & 3.66 & $\mathrm{U}$ & & HCJ-165-08 \\
\hline Aroclor-1221 & E04808010013A & Tank Vault & \#32 & 3.57 & $\mathrm{U}$ & & HCJ-165-08 \\
\hline Aroclor-1232 & E04808001013A & Pump Pit & $\# 3$ & 3.52 & $\mathrm{U}$ & & HCJ-165-08 \\
\hline Aroclor-1232 & E04808002013A & Pump Pit & $\# 12$ & 3.57 & $\mathrm{U}$ & & HCJ-165-08 \\
\hline Aroclor-1232 & E04808003013A & Pump Pit & $\# 16$ & 3.66 & $\mathrm{U}$ & & HCJ-165-08 \\
\hline Aroclor-1232 & E04808004013A & Pump Pit & $\# 18$ & 3.52 & $\mathrm{U}$ & & HCJ-165-08 \\
\hline Aroclor-1232 & E04808005013A & Pump Pit & $\# 23$ & 3.47 & $\mathrm{U}$ & & HCJ-165-08 \\
\hline Aroclor-1232 & E04808006013A & Tank Vault & $\# 8$ & 3.67 & $\mathrm{U}$ & & HCJ-165-08 \\
\hline Aroclor-1232 & E04808007013A & Tank Vault & $\# 9$ & 3.62 & $\mathrm{U}$ & & HCJ-165-08 \\
\hline Aroclor-1232 & E04808008013A & Tank Vault & $\# 15$ & 3.55 & $\mathrm{U}$ & & HCJ-165-08 \\
\hline Aroclor-1232 & E04808009013A & Tank Vault & $\# 24$ & 3.66 & $\mathrm{U}$ & & HCJ-165-08 \\
\hline Aroclor-1232 & E04808010013A & Tank Vault & $\# 32$ & 3.57 & $\mathrm{U}$ & & HCJ-165-08 \\
\hline Aroclor-1242 & E04808001013A & Pump Pit & $\# 3$ & 3.52 & $\mathrm{U}$ & & HCJ-165-08 \\
\hline Aroclor-1242 & E04808002013A & Pump Pit & $\# 12$ & 3.57 & $\mathrm{U}$ & & HCJ-165-08 \\
\hline Aroclor-1242 & E04808003013A & Pump Pit & $\# 16$ & 3.66 & $\mathrm{U}$ & & HCJ-165-08 \\
\hline Aroclor-1242 & E04808004013A & Pump Pit & $\# 18$ & 3.52 & $\mathrm{U}$ & & HCJ-165-08 \\
\hline Aroclor-1242 & E04808005013A & Pump Pit & $\# 23$ & 3.47 & $\mathrm{U}$ & & HCJ-165-08 \\
\hline Aroclor-1242 & E04808006013A & Tank Vault & $\# 8$ & 3.67 & $\mathrm{U}$ & & HCJ-165-08 \\
\hline Aroclor-1242 & E04808007013A & Tank Vault & $\# 9$ & 3.62 & $\mathrm{U}$ & & HCJ-165-08 \\
\hline Aroclor-1242 & E04808008013A & Tank Vault & $\# 15$ & 3.55 & $\mathrm{U}$ & & HCJ-165-08 \\
\hline Aroclor-1242 & E04808009013A & Tank Vault & $\# 24$ & 3.66 & $\mathrm{U}$ & & HCJ-165-08 \\
\hline Aroclor-1242 & E04808010013A & Tank Vault & \#32 & 3.57 & $\mathrm{U}$ & & HCJ-165-08 \\
\hline Aroclor-1248 & E04808001013A & Pump Pit & $\# 3$ & 3.52 & $\mathrm{U}$ & & HCJ-165-08 \\
\hline Aroclor-1248 & E04808002013A & Pump Pit & $\# 12$ & 3.57 & $\mathrm{U}$ & & HCJ-165-08 \\
\hline Aroclor-1248 & E04808003013A & Pump Pit & $\# 16$ & 3.66 & $\mathrm{U}$ & & HCJ-165-08 \\
\hline Aroclor-1248 & E04808004013A & Pump Pit & $\# 18$ & 3.52 & $\mathrm{U}$ & & HCJ-165-08 \\
\hline Aroclor-1248 & E04808005013A & Pump Pit & $\# 23$ & 3.47 & $\mathrm{U}$ & & HCJ-165-08 \\
\hline Aroclor-1248 & E04808006013A & Tank Vault & $\# 8$ & 3.67 & $\mathrm{U}$ & & HCJ-165-08 \\
\hline Aroclor-1248 & E04808007013A & Tank Vault & $\# 9$ & 3.62 & $\mathrm{U}$ & & HCJ-165-08 \\
\hline Aroclor-1248 & E04808008013A & Tank Vault & \#15 & 3.55 & $\mathrm{U}$ & & HCJ-165-08 \\
\hline
\end{tabular}


Table G-2. (continued).

\begin{tabular}{|c|c|c|c|c|c|c|c|}
\hline Compound & $\begin{array}{c}\text { Field Sample } \\
\text { Number }\end{array}$ & Location & Grid & $\begin{array}{c}\text { Sample } \\
\text { Result } \\
(\mu \mathrm{g} / \mathrm{kg})\end{array}$ & $\begin{array}{l}\text { Result } \\
\text { Qual. }\end{array}$ & $\begin{array}{l}\text { Val. } \\
\text { Flag }\end{array}$ & L\&V Report \\
\hline Aroclor-1248 & E04808009013A & Tank Vault & $\# 24$ & 3.66 & $\mathrm{U}$ & & HCJ-165-08 \\
\hline Aroclor-1248 & E04808010013A & Tank Vault & $\# 32$ & 3.57 & $\mathrm{U}$ & & HCJ-165-08 \\
\hline Aroclor-1254 & E04808001013A & Pump Pit & $\# 3$ & 3.52 & $\mathrm{U}$ & & HCJ-165-08 \\
\hline Aroclor-1254 & E04808002013A & Pump Pit & $\# 12$ & 3.57 & $\mathrm{U}$ & & HCJ-165-08 \\
\hline Aroclor-1254 & E04808003013A & Pump Pit & $\# 16$ & 3.66 & $\mathrm{U}$ & & HCJ-165-08 \\
\hline Aroclor-1254 & E04808004013A & Pump Pit & $\# 18$ & 3.52 & $\mathrm{U}$ & & HCJ-165-08 \\
\hline Aroclor-1254 & E04808005013A & Pump Pit & $\# 23$ & 3.47 & $\mathrm{U}$ & & HCJ-165-08 \\
\hline Aroclor-1254 & E04808006013A & Tank Vault & $\# 8$ & 3.67 & $\mathrm{U}$ & & HCJ-165-08 \\
\hline Aroclor-1254 & E04808007013A & Tank Vault & $\# 9$ & 3.62 & $\mathrm{U}$ & & HCJ-165-08 \\
\hline Aroclor-1254 & E04808008013A & Tank Vault & $\# 15$ & 1.8 & $\mathrm{~J}$ & & HCJ-165-08 \\
\hline Aroclor-1254 & E04808009013A & Tank Vault & $\# 24$ & 3.66 & $\mathrm{U}$ & & HCJ-165-08 \\
\hline Aroclor-1254 & E04808010013A & Tank Vault & $\# 32$ & 8.3 & & & HCJ-165-08 \\
\hline Aroclor-1260 & E04808001013A & Pump Pit & $\# 3$ & 3.52 & $\mathrm{U}$ & & HCJ-165-08 \\
\hline Aroclor- 1260 & E04808002013A & Pump Pit & $\# 12$ & 3.57 & $\mathrm{U}$ & & HCJ-165-08 \\
\hline Aroclor- 1260 & E04808003013A & Pump Pit & $\# 16$ & 3.66 & $\mathrm{U}$ & & HCJ-165-08 \\
\hline Aroclor-1260 & E04808004013A & Pump Pit & $\# 18$ & 3.52 & $\mathrm{U}$ & & HCJ-165-08 \\
\hline Aroclor-1260 & E04808005013A & Pump Pit & $\# 23$ & 3.47 & $\mathrm{U}$ & & HCJ-165-08 \\
\hline Aroclor-1260 & E04808006013A & Tank Vault & $\# 8$ & 3.67 & $\mathrm{U}$ & & HCJ-165-08 \\
\hline Aroclor-1260 & E04808007013A & Tank Vault & $\# 9$ & 3.62 & $\mathrm{U}$ & & HCJ-165-08 \\
\hline Aroclor- 1260 & E04808008013A & Tank Vault & $\# 15$ & 3.55 & $\mathrm{U}$ & & HCJ-165-08 \\
\hline Aroclor- 1260 & E04808009013A & Tank Vault & $\# 24$ & 3.66 & $\mathrm{U}$ & & HCJ-165-08 \\
\hline Aroclor-1260 & E04808010013A & Tank Vault & \#32 & 4.4 & & & HCJ-165-08 \\
\hline
\end{tabular}


Table G-3. ESP-048-08 SFE-20 soil sample results for volatile organic compounds.

\begin{tabular}{|c|c|c|c|c|c|c|c|}
\hline Compound & $\begin{array}{c}\text { Field Sample } \\
\text { Number }\end{array}$ & Location & Grid & $\begin{array}{c}\text { Sample } \\
\text { Result } \\
(\mu \mathrm{g} / \mathrm{kg})\end{array}$ & $\begin{array}{l}\text { Result } \\
\text { Qual. }\end{array}$ & $\begin{array}{l}\text { Val. } \\
\text { Flag } \\
\end{array}$ & $\begin{array}{c}\text { L\&V Report } \\
\text { Number }\end{array}$ \\
\hline $1,1,1,2$-Tetrachloroethane & E04808001013A & Pump Pit & $\# 3$ & 1.06 & $\mathrm{U}$ & & HCJ-164-08 \\
\hline $1,1,1,2$-Tetrachloroethane & E04808002013A & Pump Pit & $\# 12$ & 1.07 & $\mathrm{U}$ & & HCJ-164-08 \\
\hline 1,1,1,2-Tetrachloroethane & E04808003013A & Pump Pit & $\# 16$ & 1.1 & $\mathrm{U}$ & & HCJ-164-08 \\
\hline 1,1,1,2-Tetrachloroethane & E04808004013A & Pump Pit & $\# 18$ & 1.06 & $\mathrm{U}$ & & HCJ-164-08 \\
\hline $1,1,1,2$-Tetrachloroethane & E04808005013A & Pump Pit & $\# 23$ & 1.04 & $\mathrm{U}$ & & HCJ-164-08 \\
\hline $1,1,1,2$-Tetrachloroethane & E04808006013A & Tank Vault & $\# 8$ & 1.1 & $\mathrm{U}$ & & HCJ-164-08 \\
\hline $1,1,1,2$-Tetrachloroethane & E04808007013A & Tank Vault & $\# 9$ & 1.09 & $\mathrm{U}$ & & HCJ-164-08 \\
\hline $1,1,1,2$-Tetrachloroethane & E04808008013A & Tank Vault & \#15 & 1.07 & $\mathrm{U}$ & & HCJ-164-08 \\
\hline $1,1,1,2$-Tetrachloroethane & E04808009013A & Tank Vault & $\# 24$ & 1.1 & $\mathrm{U}$ & & HCJ-164-08 \\
\hline $1,1,1,2$-Tetrachloroethane & E04808010013A & Tank Vault & $\# 32$ & 1.07 & $\mathrm{U}$ & & HCJ-164-08 \\
\hline 1,1,1-Trichloroethane & E04808001013A & Pump Pit & $\# 3$ & 1.06 & $\mathrm{U}$ & & HCJ-164-08 \\
\hline 1,1,1-Trichloroethane & E04808002013A & Pump Pit & $\# 12$ & 1.07 & $\mathrm{U}$ & & HCJ-164-08 \\
\hline 1,1,1-Trichloroethane & E04808003013A & Pump Pit & $\# 16$ & 1.1 & $\mathrm{U}$ & & HCJ-164-08 \\
\hline 1,1,1-Trichloroethane & E04808004013A & Pump Pit & $\# 18$ & 1.06 & $\mathrm{U}$ & & HCJ-164-08 \\
\hline $1,1,1$-Trichloroethane & E04808005013A & Pump Pit & $\# 23$ & 1.04 & $\mathrm{U}$ & & HCJ-164-08 \\
\hline 1,1,1-Trichloroethane & E04808006013A & Tank Vault & $\# 8$ & 1.1 & $\mathrm{U}$ & & HCJ-164-08 \\
\hline $1,1,1$-Trichloroethane & E04808007013A & Tank Vault & $\# 9$ & 1.09 & $\mathrm{U}$ & & HCJ-164-08 \\
\hline 1,1,1-Trichloroethane & E04808008013A & Tank Vault & $\# 15$ & 1.07 & $\mathrm{U}$ & & HCJ-164-08 \\
\hline 1,1,1-Trichloroethane & E04808009013A & Tank Vault & $\# 24$ & 1.1 & $\mathrm{U}$ & & HCJ-164-08 \\
\hline 1,1,1-Trichloroethane & E04808010013A & Tank Vault & \#32 & 1.07 & $\mathrm{U}$ & & HCJ-164-08 \\
\hline 1,1,2,2-Tetrachloroethane & E04808001013A & Pump Pit & $\# 3$ & 1.06 & $\mathrm{U}$ & & HCJ-164-08 \\
\hline $1,1,2,2$-Tetrachloroethane & E04808002013A & Pump Pit & $\# 12$ & 1.07 & $\mathrm{U}$ & & HCJ-164-08 \\
\hline $1,1,2,2$-Tetrachloroethane & E04808003013A & Pump Pit & $\# 16$ & 1.1 & $\mathrm{U}$ & & HCJ-164-08 \\
\hline $1,1,2,2$-Tetrachloroethane & E04808004013A & Pump Pit & $\# 18$ & 1.06 & $\mathrm{U}$ & & HCJ-164-08 \\
\hline $1,1,2,2$-Tetrachloroethane & E04808005013A & Pump Pit & \#23 & 1.04 & $\mathrm{U}$ & & HCJ-164-08 \\
\hline $1,1,2,2$-Tetrachloroethane & E04808006013A & Tank Vault & $\# 8$ & 1.1 & $\mathrm{U}$ & & HCJ-164-08 \\
\hline $1,1,2,2$-Tetrachloroethane & E04808007013A & Tank Vault & $\# 9$ & 1.09 & $\mathrm{U}$ & & HCJ-164-08 \\
\hline $1,1,2,2$-Tetrachloroethane & E04808008013A & Tank Vault & $\# 15$ & 1.07 & $\mathrm{U}$ & & HCJ-164-08 \\
\hline $1,1,2,2$-Tetrachloroethane & E04808009013A & Tank Vault & $\# 24$ & 1.1 & $\mathrm{U}$ & & HCJ-164-08 \\
\hline $1,1,2,2$-Tetrachloroethane & E04808010013A & Tank Vault & \#32 & 1.07 & $\mathrm{U}$ & & HCJ-164-08 \\
\hline 1,1,2-Trichloroethane & E04808001013A & Pump Pit & $\# 3$ & 1.06 & $\mathrm{U}$ & & HCJ-164-08 \\
\hline 1,1,2-Trichloroethane & E04808002013A & Pump Pit & $\# 12$ & 1.07 & $\mathrm{U}$ & & HCJ-164-08 \\
\hline 1,1,2-Trichloroethane & E04808003013A & Pump Pit & $\# 16$ & 1.1 & $\mathrm{U}$ & & HCJ-164-08 \\
\hline 1,1,2-Trichloroethane & E04808004013A & Pump Pit & $\# 18$ & 1.06 & $\mathrm{U}$ & & HCJ-164-08 \\
\hline 1,1,2-Trichloroethane & E04808005013A & Pump Pit & \#23 & 1.04 & $\mathrm{U}$ & & HCJ-164-08 \\
\hline 1,1,2-Trichloroethane & E04808006013A & Tank Vault & $\# 8$ & 1.1 & $\mathrm{U}$ & & HCJ-164-08 \\
\hline 1,1,2-Trichloroethane & E04808007013A & Tank Vault & $\# 9$ & 1.09 & $\mathrm{U}$ & & HCJ-164-08 \\
\hline 1,1,2-Trichloroethane & E04808008013A & Tank Vault & $\# 15$ & 1.07 & $\mathrm{U}$ & & HCJ-164-08 \\
\hline 1,1,2-Trichloroethane & E04808009013A & Tank Vault & $\# 24$ & 1.1 & $\mathrm{U}$ & & HCJ-164-08 \\
\hline 1,1,2-Trichloroethane & E04808010013A & Tank Vault & $\# 32$ & 1.07 & $\mathrm{U}$ & & HCJ-164-08 \\
\hline 1,1-Dichloroethane & E04808001013A & Pump Pit & $\# 3$ & 1.06 & $\mathrm{U}$ & & HCJ-164-08 \\
\hline 1,1-Dichloroethane & E04808002013A & Pump Pit & $\# 12$ & 1.07 & $\mathrm{U}$ & & HCJ-164-08 \\
\hline 1,1-Dichloroethane & E04808003013A & Pump Pit & $\# 16$ & 1.1 & $\mathrm{U}$ & & HCJ-164-08 \\
\hline 1,1-Dichloroethane & E04808004013A & Pump Pit & $\# 18$ & 1.06 & $\mathrm{U}$ & & HCJ-164-08 \\
\hline 1,1-Dichloroethane & E04808005013A & Pump Pit & $\# 23$ & 1.04 & $\mathrm{U}$ & & HCJ-164-08 \\
\hline 1,1-Dichloroethane & E04808006013A & Tank Vault & $\# 8$ & 1.1 & $\mathrm{U}$ & & HCJ-164-08 \\
\hline 1,1-Dichloroethane & E04808007013A & Tank Vault & $\# 9$ & 1.09 & $\mathrm{U}$ & & HCJ-164-08 \\
\hline
\end{tabular}


Table G-3. (continued).

\begin{tabular}{|c|c|c|c|c|c|c|c|}
\hline Compound & $\begin{array}{c}\text { Field Sample } \\
\text { Number }\end{array}$ & Location & Grid & $\begin{array}{c}\text { Sample } \\
\text { Result } \\
(\mu \mathrm{g} / \mathrm{kg})\end{array}$ & $\begin{array}{l}\text { Result } \\
\text { Qual. }\end{array}$ & $\begin{array}{l}\text { Val. } \\
\text { Flag }\end{array}$ & $\begin{array}{c}\text { L\&V Report } \\
\text { Number }\end{array}$ \\
\hline 1,1-Dichloroethane & E04808008013A & Tank Vault & $\# 15$ & 1.07 & $\mathrm{U}$ & & HCJ-164-08 \\
\hline 1,1-Dichloroethane & E04808009013A & Tank Vault & $\# 24$ & 1.1 & $\mathrm{U}$ & & HCJ-164-08 \\
\hline 1,1-Dichloroethane & E04808010013A & Tank Vault & $\# 32$ & 1.07 & $\mathrm{U}$ & & HCJ-164-08 \\
\hline 1,1-Dichloroethene & E04808001013A & Pump Pit & $\# 3$ & 1.06 & $\mathrm{U}$ & & HCJ-164-08 \\
\hline 1,1-Dichloroethene & E04808002013A & Pump Pit & $\# 12$ & 1.07 & $\mathrm{U}$ & & HCJ-164-08 \\
\hline 1,1-Dichloroethene & E04808003013A & Pump Pit & $\# 16$ & 1.1 & $\mathrm{U}$ & & HCJ-164-08 \\
\hline 1,1-Dichloroethene & E04808004013A & Pump Pit & $\# 18$ & 1.06 & $\mathrm{U}$ & & HCJ-164-08 \\
\hline 1,1-Dichloroethene & E04808005013A & Pump Pit & $\# 23$ & 1.04 & $\mathrm{U}$ & & HCJ-164-08 \\
\hline 1,1-Dichloroethene & E04808006013A & Tank Vault & $\# 8$ & 1.1 & $\mathrm{U}$ & & HCJ-164-08 \\
\hline 1,1-Dichloroethene & E04808007013A & Tank Vault & $\# 9$ & 1.09 & $\mathrm{U}$ & & HCJ-164-08 \\
\hline 1,1-Dichloroethene & E04808008013A & Tank Vault & $\# 15$ & 1.07 & $\mathrm{U}$ & & HCJ-164-08 \\
\hline 1,1-Dichloroethene & E04808009013A & Tank Vault & $\# 24$ & 1.1 & $\mathrm{U}$ & & HCJ-164-08 \\
\hline 1,1-Dichloroethene & E04808010013A & Tank Vault & $\# 32$ & 1.07 & $\mathrm{U}$ & & HCJ-164-08 \\
\hline 1,2,3-Trichloropropane & E04808001013A & Pump Pit & $\# 3$ & 1.06 & $\mathrm{U}$ & & HCJ-164-08 \\
\hline 1,2,3-Trichloropropane & E04808002013A & Pump Pit & $\# 12$ & 1.07 & $\mathrm{U}$ & & HCJ-164-08 \\
\hline 1,2,3-Trichloropropane & E04808003013A & Pump Pit & $\# 16$ & 1.1 & $\mathrm{U}$ & & HCJ-164-08 \\
\hline 1,2,3-Trichloropropane & E04808004013A & Pump Pit & $\# 18$ & 1.06 & $\mathrm{U}$ & & HCJ-164-08 \\
\hline 1,2,3-Trichloropropane & E04808005013A & Pump Pit & $\# 23$ & 1.04 & $\mathrm{U}$ & & HCJ-164-08 \\
\hline 1,2,3-Trichloropropane & E04808006013A & Tank Vault & $\# 8$ & 1.1 & $\mathrm{U}$ & & HCJ-164-08 \\
\hline 1,2,3-Trichloropropane & E04808007013A & Tank Vault & $\# 9$ & 1.09 & $\mathrm{U}$ & & HCJ-164-08 \\
\hline 1,2,3-Trichloropropane & E04808008013A & Tank Vault & $\# 15$ & 1.07 & $\mathrm{U}$ & & HCJ-164-08 \\
\hline 1,2,3-Trichloropropane & E04808009013A & Tank Vault & $\# 24$ & 1.1 & $\mathrm{U}$ & & HCJ-164-08 \\
\hline 1,2,3-Trichloropropane & E04808010013A & Tank Vault & $\# 32$ & 1.07 & $\mathrm{U}$ & & HCJ-164-08 \\
\hline 1,2-Dibromo-3-chloropropane & E04808001013A & Pump Pit & $\# 3$ & 1.06 & $\mathrm{U}$ & & HCJ-164-08 \\
\hline 1,2-Dibromo-3-chloropropane & E04808002013A & Pump Pit & $\# 12$ & 1.07 & $\mathrm{U}$ & & HCJ-164-08 \\
\hline 1,2-Dibromo-3-chloropropane & E04808003013A & Pump Pit & $\# 16$ & 1.1 & $\mathrm{U}$ & & HCJ-164-08 \\
\hline 1,2-Dibromo-3-chloropropane & E04808004013A & Pump Pit & $\# 18$ & 1.06 & $\mathrm{U}$ & & HCJ-164-08 \\
\hline 1,2-Dibromo-3-chloropropane & E04808005013A & Pump Pit & $\# 23$ & 1.04 & $\mathrm{U}$ & & HCJ-164-08 \\
\hline 1,2-Dibromo-3-chloropropane & E04808006013A & Tank Vault & $\# 8$ & 1.1 & $\mathrm{U}$ & & HCJ-164-08 \\
\hline 1,2-Dibromo-3-chloropropane & E04808007013A & Tank Vault & $\# 9$ & 1.09 & $\mathrm{U}$ & & HCJ-164-08 \\
\hline 1,2-Dibromo-3-chloropropane & E04808008013A & Tank Vault & $\# 15$ & 1.07 & $\mathrm{U}$ & & HCJ-164-08 \\
\hline 1,2-Dibromo-3-chloropropane & E04808009013A & Tank Vault & $\# 24$ & 1.1 & $\mathrm{U}$ & & HCJ-164-08 \\
\hline 1,2-Dibromo-3-chloropropane & E04808010013A & Tank Vault & \#32 & 1.07 & $\mathrm{U}$ & & HCJ-164-08 \\
\hline 1,2-Dibromoethane & E04808001013A & Pump Pit & $\# 3$ & 1.06 & $\mathrm{U}$ & & HCJ-164-08 \\
\hline 1,2-Dibromoethane & E04808002013A & Pump Pit & $\# 12$ & 1.07 & $\mathrm{U}$ & & HCJ-164-08 \\
\hline 1,2-Dibromoethane & E04808003013A & Pump Pit & $\# 16$ & 1.1 & $\mathrm{U}$ & & HCJ-164-08 \\
\hline 1,2-Dibromoethane & E04808004013A & Pump Pit & $\# 18$ & 1.06 & $\mathrm{U}$ & & HCJ-164-08 \\
\hline 1,2-Dibromoethane & E04808005013A & Pump Pit & $\# 23$ & 1.04 & $\mathrm{U}$ & & HCJ-164-08 \\
\hline 1,2-Dibromoethane & E04808006013A & Tank Vault & $\# 8$ & 1.1 & $\mathrm{U}$ & & HCJ-164-08 \\
\hline 1,2-Dibromoethane & E04808007013A & Tank Vault & $\# 9$ & 1.09 & $\mathrm{U}$ & & HCJ-164-08 \\
\hline 1,2-Dibromoethane & E04808008013A & Tank Vault & $\# 15$ & 1.07 & $\mathrm{U}$ & & HCJ-164-08 \\
\hline 1,2-Dibromoethane & E04808009013A & Tank Vault & $\# 24$ & 1.1 & $\mathrm{U}$ & & HCJ-164-08 \\
\hline 1,2-Dibromoethane & E04808010013A & Tank Vault & $\# 32$ & 1.07 & $\mathrm{U}$ & & HCJ-164-08 \\
\hline 1,2-Dichlorobenzene & E04808001013A & Pump Pit & $\# 3$ & 1.06 & $\mathrm{U}$ & & HCJ-164-08 \\
\hline 1,2-Dichlorobenzene & E04808002013A & Pump Pit & $\# 12$ & 1.07 & $\mathrm{U}$ & & HCJ-164-08 \\
\hline 1,2-Dichlorobenzene & E04808003013A & Pump Pit & $\# 16$ & 1.1 & $\mathrm{U}$ & & HCJ-164-08 \\
\hline 1,2-Dichlorobenzene & E04808004013A & Pump Pit & $\# 18$ & 1.06 & $\mathrm{U}$ & & HCJ-164-08 \\
\hline 1,2-Dichlorobenzene & E04808005013A & Pump Pit & $\# 23$ & 1.04 & $\mathrm{U}$ & & HCJ-164-08 \\
\hline
\end{tabular}


Table G-3. (continued).

\begin{tabular}{|c|c|c|c|c|c|c|c|}
\hline Compound & $\begin{array}{l}\text { Field Sample } \\
\text { Number }\end{array}$ & Location & Grid & $\begin{array}{c}\text { Sample } \\
\text { Result } \\
(\mu \mathrm{g} / \mathrm{kg})\end{array}$ & $\begin{array}{l}\text { Result } \\
\text { Qual. }\end{array}$ & $\begin{array}{l}\text { Val. } \\
\text { Flag }\end{array}$ & $\begin{array}{l}\text { L\&V Report } \\
\text { Number }\end{array}$ \\
\hline 1,2-Dichlorobenzene & E04808006013A & Tank Vault & $\# 8$ & 1.1 & $\mathrm{U}$ & & HCJ-164-08 \\
\hline 1,2-Dichlorobenzene & E04808007013A & Tank Vault & $\# 9$ & 1.09 & $\mathrm{U}$ & & HCJ-164-08 \\
\hline 1,2-Dichlorobenzene & E04808008013A & Tank Vault & $\# 15$ & 1.07 & $\mathrm{U}$ & & HCJ-164-08 \\
\hline 1,2-Dichlorobenzene & E04808009013A & Tank Vault & \#24 & 1.1 & $\mathrm{U}$ & & HCJ-164-08 \\
\hline 1,2-Dichlorobenzene & E04808010013A & Tank Vault & \#32 & 1.07 & $\mathrm{U}$ & & HCJ-164-08 \\
\hline 1,2-Dichloroethane & E04808001013A & Pump Pit & $\# 3$ & 1.06 & $\mathrm{U}$ & & HCJ-164-08 \\
\hline 1,2-Dichloroethane & E04808002013A & Pump Pit & \#12 & 1.07 & $\mathrm{U}$ & & HCJ-164-08 \\
\hline 1,2-Dichloroethane & E04808003013A & Pump Pit & $\# 16$ & 1.1 & $\mathrm{U}$ & & HCJ-164-08 \\
\hline 1,2-Dichloroethane & E04808004013A & Pump Pit & $\# 18$ & 1.06 & $\mathrm{U}$ & & HCJ-164-08 \\
\hline 1,2-Dichloroethane & E04808005013A & Pump Pit & $\# 23$ & 1.04 & $\mathrm{U}$ & & HCJ-164-08 \\
\hline 1,2-Dichloroethane & E04808006013A & Tank Vault & $\# 8$ & 1.1 & $\mathrm{U}$ & & HCJ-164-08 \\
\hline 1,2-Dichloroethane & E04808007013A & Tank Vault & $\# 9$ & 1.09 & $\mathrm{U}$ & & HCJ-164-08 \\
\hline 1,2-Dichloroethane & E04808008013A & Tank Vault & $\# 15$ & 1.07 & $\mathrm{U}$ & & HCJ-164-08 \\
\hline 1,2-Dichloroethane & E04808009013A & Tank Vault & $\# 24$ & 1.1 & $\mathrm{U}$ & & HCJ-164-08 \\
\hline 1,2-Dichloroethane & E04808010013A & Tank Vault & \#32 & 1.07 & $\mathrm{U}$ & & HCJ-164-08 \\
\hline 1,2-Dichloropropane & E04808001013A & Pump Pit & $\# 3$ & 1.06 & $\mathrm{U}$ & & HCJ-164-08 \\
\hline 1,2-Dichloropropane & E04808002013A & Pump Pit & $\# 12$ & 1.07 & $\mathrm{U}$ & & HCJ-164-08 \\
\hline 1,2-Dichloropropane & E04808003013A & Pump Pit & $\# 16$ & 1.1 & $\mathrm{U}$ & & HCJ-164-08 \\
\hline 1,2-Dichloropropane & E04808004013A & Pump Pit & $\# 18$ & 1.06 & $\mathrm{U}$ & & HCJ-164-08 \\
\hline 1,2-Dichloropropane & E04808005013A & Pump Pit & $\# 23$ & 1.04 & $\mathrm{U}$ & & HCJ-164-08 \\
\hline 1,2-Dichloropropane & E04808006013A & Tank Vault & $\# 8$ & 1.1 & $\mathrm{U}$ & & HCJ-164-08 \\
\hline 1,2-Dichloropropane & E04808007013A & Tank Vault & $\# 9$ & 1.09 & $\mathrm{U}$ & & HCJ-164-08 \\
\hline 1,2-Dichloropropane & E04808008013A & Tank Vault & $\# 15$ & 1.07 & $\mathrm{U}$ & & HCJ-164-08 \\
\hline 1,2-Dichloropropane & E04808009013A & Tank Vault & $\# 24$ & 1.1 & $\mathrm{U}$ & & HCJ-164-08 \\
\hline 1,2-Dichloropropane & E04808010013A & Tank Vault & \#32 & 1.07 & $\mathrm{U}$ & & HCJ-164-08 \\
\hline 1,3-Dichlorobenzene & E04808001013A & Pump Pit & $\# 3$ & 1.06 & $\mathrm{U}$ & & HCJ-164-08 \\
\hline 1,3-Dichlorobenzene & E04808002013A & Pump Pit & \#12 & 1.07 & $\mathrm{U}$ & & HCJ-164-08 \\
\hline 1,3-Dichlorobenzene & E04808003013A & Pump Pit & $\# 16$ & 1.1 & $\mathrm{U}$ & & HCJ-164-08 \\
\hline 1,3-Dichlorobenzene & E04808004013A & Pump Pit & $\# 18$ & 1.06 & $\mathrm{U}$ & & HCJ-164-08 \\
\hline 1,3-Dichlorobenzene & E04808005013A & Pump Pit & $\# 23$ & 1.04 & $\mathrm{U}$ & & HCJ-164-08 \\
\hline 1,3-Dichlorobenzene & E04808006013A & Tank Vault & $\# 8$ & 1.1 & $\mathrm{U}$ & & HCJ-164-08 \\
\hline 1,3-Dichlorobenzene & E04808007013A & Tank Vault & $\# 9$ & 1.09 & $\mathrm{U}$ & & HCJ-164-08 \\
\hline 1,3-Dichlorobenzene & E04808008013A & Tank Vault & $\# 15$ & 1.07 & $\mathrm{U}$ & & HCJ-164-08 \\
\hline 1,3-Dichlorobenzene & E04808009013A & Tank Vault & $\# 24$ & 1.1 & $\mathrm{U}$ & & HCJ-164-08 \\
\hline 1,3-Dichlorobenzene & E04808010013A & Tank Vault & \#32 & 1.07 & $\mathrm{U}$ & & HCJ-164-08 \\
\hline 1,4-Dichlorobenzene & E04808001013A & Pump Pit & $\# 3$ & 1.06 & $\mathrm{U}$ & & HCJ-164-08 \\
\hline 1,4-Dichlorobenzene & E04808002013A & Pump Pit & $\# 12$ & 1.07 & $\mathrm{U}$ & & HCJ-164-08 \\
\hline 1,4-Dichlorobenzene & E04808003013A & Pump Pit & $\# 16$ & 1.1 & $\mathrm{U}$ & & HCJ-164-08 \\
\hline 1,4-Dichlorobenzene & E04808004013A & Pump Pit & $\# 18$ & 1.06 & $\mathrm{U}$ & & HCJ-164-08 \\
\hline 1,4-Dichlorobenzene & E04808005013A & Pump Pit & $\# 23$ & 1.04 & $\mathrm{U}$ & & HCJ-164-08 \\
\hline 1,4-Dichlorobenzene & E04808006013A & Tank Vault & $\# 8$ & 1.1 & $\mathrm{U}$ & & HCJ-164-08 \\
\hline 1,4-Dichlorobenzene & E04808007013A & Tank Vault & $\# 9$ & 1.09 & $\mathrm{U}$ & & HCJ-164-08 \\
\hline 1,4-Dichlorobenzene & E04808008013A & Tank Vault & $\# 15$ & 1.07 & $\mathrm{U}$ & & HCJ-164-08 \\
\hline 1,4-Dichlorobenzene & E04808009013A & Tank Vault & $\# 24$ & 1.1 & $\mathrm{U}$ & & HCJ-164-08 \\
\hline 1,4-Dichlorobenzene & E04808010013A & Tank Vault & \#32 & 1.07 & $\mathrm{U}$ & & HCJ-164-08 \\
\hline 1,4-Dioxane & E04808001013A & Pump Pit & $\# 3$ & 53 & $\mathrm{U}$ & $\mathrm{R}$ & HCJ-164-08 \\
\hline 1,4-Dioxane & E04808002013A & Pump Pit & $\# 12$ & 53.6 & $\mathrm{U}$ & $\mathrm{R}$ & HCJ-164-08 \\
\hline 1,4-Dioxane & E04808003013A & Pump Pit & $\# 16$ & 55 & $\mathrm{U}$ & $\mathrm{R}$ & HCJ-164-08 \\
\hline
\end{tabular}


Table G-3. (continued).

\begin{tabular}{|c|c|c|c|c|c|c|c|}
\hline Compound & $\begin{array}{l}\text { Field Sample } \\
\text { Number }\end{array}$ & Location & Grid & $\begin{array}{c}\text { Sample } \\
\text { Result } \\
(\mu \mathrm{g} / \mathrm{kg})\end{array}$ & $\begin{array}{l}\text { Result } \\
\text { Qual. }\end{array}$ & $\begin{array}{l}\text { Val. } \\
\text { Flag }\end{array}$ & $\begin{array}{l}\text { L\&V Report } \\
\text { Number }\end{array}$ \\
\hline 1,4-Dioxane & E04808004013A & Pump Pit & $\# 18$ & 52.8 & $\mathrm{U}$ & $\mathrm{R}$ & HCJ-164-08 \\
\hline 1,4-Dioxane & E04808005013A & Pump Pit & \#23 & 52.2 & $\mathrm{U}$ & $\mathrm{R}$ & HCJ-164-08 \\
\hline 1,4-Dioxane & E04808006013A & Tank Vault & $\# 8$ & 55 & $\mathrm{U}$ & $\mathrm{R}$ & HCJ-164-08 \\
\hline 1,4-Dioxane & E04808007013A & Tank Vault & $\# 9$ & 54.4 & $\mathrm{U}$ & $\mathrm{R}$ & HCJ-164-08 \\
\hline 1,4-Dioxane & E04808008013A & Tank Vault & $\# 15$ & 53.4 & $\mathrm{U}$ & $\mathrm{R}$ & HCJ-164-08 \\
\hline 1,4-Dioxane & E04808009013A & Tank Vault & $\# 24$ & 55 & $\mathrm{U}$ & $\mathrm{R}$ & HCJ-164-08 \\
\hline 1,4-Dioxane & E04808010013A & Tank Vault & \#32 & 53.6 & $\mathrm{U}$ & $\mathrm{R}$ & HCJ-164-08 \\
\hline 2-Butanone & E04808001013A & Pump Pit & $\# 3$ & 5.3 & $\mathrm{U}$ & & HCJ-164-08 \\
\hline 2-Butanone & E04808002013A & Pump Pit & $\# 12$ & 5.36 & $\mathrm{U}$ & & HCJ-164-08 \\
\hline 2-Butanone & E04808003013A & Pump Pit & $\# 16$ & 5.5 & $\mathrm{U}$ & & HCJ-164-08 \\
\hline 2-Butanone & E04808004013A & Pump Pit & $\# 18$ & 5.28 & $\mathrm{U}$ & & HCJ-164-08 \\
\hline 2-Butanone & E04808005013A & Pump Pit & \#23 & 5.22 & $\mathrm{U}$ & & HCJ-164-08 \\
\hline 2-Butanone & E04808006013A & Tank Vault & $\# 8$ & 5.5 & $\mathrm{U}$ & & HCJ-164-08 \\
\hline 2-Butanone & E04808007013A & Tank Vault & $\# 9$ & 5.44 & $\mathrm{U}$ & & HCJ-164-08 \\
\hline 2-Butanone & E04808008013A & Tank Vault & $\# 15$ & 5.34 & $\mathrm{U}$ & & HCJ-164-08 \\
\hline 2-Butanone & E04808009013A & Tank Vault & $\# 24$ & 5.5 & $\mathrm{U}$ & & HCJ-164-08 \\
\hline 2-Butanone & E04808010013A & Tank Vault & \#32 & 5.36 & $\mathrm{U}$ & & HCJ-164-08 \\
\hline 2-Chloro-1,3-butadiene & E04808001013A & Pump Pit & $\# 3$ & 1.06 & $\mathrm{U}$ & & HCJ-164-08 \\
\hline 2-Chloro-1,3-butadiene & E04808002013A & Pump Pit & $\# 12$ & 1.07 & $\mathrm{U}$ & & HCJ-164-08 \\
\hline 2-Chloro-1,3-butadiene & E04808003013A & Pump Pit & $\# 16$ & 1.1 & $\mathrm{U}$ & & HCJ-164-08 \\
\hline 2-Chloro-1,3-butadiene & E04808004013A & Pump Pit & $\# 18$ & 1.06 & $\mathrm{U}$ & & HCJ-164-08 \\
\hline 2-Chloro-1,3-butadiene & E04808005013A & Pump Pit & $\# 23$ & 1.04 & $\mathrm{U}$ & & HCJ-164-08 \\
\hline 2-Chloro-1,3-butadiene & E04808006013A & Tank Vault & $\# 8$ & 1.1 & $\mathrm{U}$ & & HCJ-164-08 \\
\hline 2-Chloro-1,3-butadiene & E04808007013A & Tank Vault & $\# 9$ & 1.09 & $\mathrm{U}$ & & HCJ-164-08 \\
\hline 2-Chloro-1,3-butadiene & E04808008013A & Tank Vault & $\# 15$ & 1.07 & $\mathrm{U}$ & & HCJ-164-08 \\
\hline 2-Chloro-1,3-butadiene & E04808009013A & Tank Vault & $\# 24$ & 1.1 & $\mathrm{U}$ & & HCJ-164-08 \\
\hline 2-Chloro-1,3-butadiene & E04808010013A & Tank Vault & $\# 32$ & 1.07 & $\mathrm{U}$ & & HCJ-164-08 \\
\hline 2-Hexanone & E04808001013A & Pump Pit & $\# 3$ & 5.3 & $\mathrm{U}$ & & HCJ-164-08 \\
\hline 2-Hexanone & E04808002013A & Pump Pit & $\# 12$ & 5.36 & $\mathrm{U}$ & & HCJ-164-08 \\
\hline 2-Hexanone & E04808003013A & Pump Pit & $\# 16$ & 5.5 & $\mathrm{U}$ & & HCJ-164-08 \\
\hline 2-Hexanone & E04808004013A & Pump Pit & $\# 18$ & 5.28 & $\mathrm{U}$ & & HCJ-164-08 \\
\hline 2-Hexanone & E04808005013A & Pump Pit & \#23 & 5.22 & $\mathrm{U}$ & & HCJ-164-08 \\
\hline 2-Hexanone & E04808006013A & Tank Vault & $\# 8$ & 5.5 & $\mathrm{U}$ & & HCJ-164-08 \\
\hline 2-Hexanone & E04808007013A & Tank Vault & $\# 9$ & 5.44 & $\mathrm{U}$ & & HCJ-164-08 \\
\hline 2-Hexanone & E04808008013A & Tank Vault & $\# 15$ & 5.34 & $\mathrm{U}$ & & HCJ-164-08 \\
\hline 2-Hexanone & E04808009013A & Tank Vault & $\# 24$ & 5.5 & $\mathrm{U}$ & & HCJ-164-08 \\
\hline 2-Hexanone & E04808010013A & Tank Vault & \#32 & 5.36 & $\mathrm{U}$ & & HCJ-164-08 \\
\hline 4-Methyl-2-pentanone & E04808001013A & Pump Pit & $\# 3$ & 5.3 & $\mathrm{U}$ & & HCJ-164-08 \\
\hline 4-Methyl-2-pentanone & E04808002013A & Pump Pit & $\# 12$ & 5.36 & $\mathrm{U}$ & & HCJ-164-08 \\
\hline 4-Methyl-2-pentanone & E04808003013A & Pump Pit & $\# 16$ & 5.5 & $\mathrm{U}$ & & HCJ-164-08 \\
\hline 4-Methyl-2-pentanone & E04808004013A & Pump Pit & $\# 18$ & 5.28 & $\mathrm{U}$ & & HCJ-164-08 \\
\hline 4-Methyl-2-pentanone & E04808005013A & Pump Pit & $\# 23$ & 5.22 & $\mathrm{U}$ & & HCJ-164-08 \\
\hline 4-Methyl-2-pentanone & E04808006013A & Tank Vault & $\# 8$ & 5.5 & $\mathrm{U}$ & & HCJ-164-08 \\
\hline 4-Methyl-2-pentanone & E04808007013A & Tank Vault & $\# 9$ & 5.44 & $\mathrm{U}$ & & HCJ-164-08 \\
\hline 4-Methyl-2-pentanone & E04808008013A & Tank Vault & $\# 15$ & 5.34 & $\mathrm{U}$ & & HCJ-164-08 \\
\hline 4-Methyl-2-pentanone & E04808009013A & Tank Vault & $\# 24$ & 5.5 & $\mathrm{U}$ & & HCJ-164-08 \\
\hline 4-Methyl-2-pentanone & E04808010013A & Tank Vault & \#32 & 5.36 & $\mathrm{U}$ & & HCJ-164-08 \\
\hline
\end{tabular}


Table G-3. (continued).

\begin{tabular}{|c|c|c|c|c|c|c|c|}
\hline Compound & $\begin{array}{l}\text { Field Sample } \\
\text { Number }\end{array}$ & Location & Grid & $\begin{array}{c}\text { Sample } \\
\text { Result } \\
(\mu \mathrm{g} / \mathrm{kg})\end{array}$ & $\begin{array}{l}\text { Result } \\
\text { Qual. }\end{array}$ & $\begin{array}{l}\text { Val. } \\
\text { Flag }\end{array}$ & $\begin{array}{l}\text { L\&V Report } \\
\text { Number }\end{array}$ \\
\hline Acetone & E04808001013A & Pump Pit & $\# 3$ & 5.3 & $\mathrm{U}$ & & HCJ-164-08 \\
\hline Acetone & E04808002013A & Pump Pit & \#12 & 5.36 & $\mathrm{U}$ & & HCJ-164-08 \\
\hline Acetone & E04808003013A & Pump Pit & $\# 16$ & 3.36 & $\mathrm{~J}$ & & HCJ-164-08 \\
\hline Acetone & E04808004013A & Pump Pit & $\# 18$ & 5.28 & $\mathrm{U}$ & & HCJ-164-08 \\
\hline Acetone & E04808005013A & Pump Pit & \#23 & 5.22 & $\mathrm{U}$ & & HCJ-164-08 \\
\hline Acetone & E04808006013A & Tank Vault & $\# 8$ & 5.5 & $\mathrm{U}$ & & HCJ-164-08 \\
\hline Acetone & E04808007013A & Tank Vault & $\# 9$ & 3.55 & $\mathrm{~J}$ & & HCJ-164-08 \\
\hline Acetone & E04808008013A & Tank Vault & $\# 15$ & 5.34 & $\mathrm{U}$ & & HCJ-164-08 \\
\hline Acetone & E04808009013A & Tank Vault & $\# 24$ & 5.5 & $\mathrm{U}$ & & HCJ-164-08 \\
\hline Acetone & E04808010013A & Tank Vault & \#32 & 1.83 & $\mathrm{~J}$ & & HCJ-164-08 \\
\hline Acetonitrile & E04808001013A & Pump Pit & $\# 3$ & 26.5 & $\mathrm{U}$ & $\mathrm{R}$ & HCJ-164-08 \\
\hline Acetonitrile & E04808002013A & Pump Pit & \#12 & 26.8 & $\mathrm{U}$ & $\mathrm{R}$ & HCJ-164-08 \\
\hline Acetonitrile & E04808003013A & Pump Pit & $\# 16$ & 27.5 & $\mathrm{U}$ & $\mathrm{R}$ & HCJ-164-08 \\
\hline Acetonitrile & E04808004013A & Pump Pit & $\# 18$ & 26.4 & $\mathrm{U}$ & $\mathrm{R}$ & HCJ-164-08 \\
\hline Acetonitrile & E04808005013A & Pump Pit & \#23 & 26.1 & $\mathrm{U}$ & $\mathrm{R}$ & HCJ-164-08 \\
\hline Acetonitrile & E04808006013A & Tank Vault & $\# 8$ & 27.5 & $\mathrm{U}$ & $\mathrm{R}$ & HCJ-164-08 \\
\hline Acetonitrile & E04808007013A & Tank Vault & $\# 9$ & 27.2 & $\mathrm{U}$ & $\mathrm{R}$ & HCJ-164-08 \\
\hline Acetonitrile & E04808008013A & Tank Vault & $\# 15$ & 26.7 & $\mathrm{U}$ & $\mathrm{R}$ & HCJ-164-08 \\
\hline Acetonitrile & E04808009013A & Tank Vault & $\# 24$ & 27.5 & $\mathrm{U}$ & $\mathrm{R}$ & HCJ-164-08 \\
\hline Acetonitrile & E04808010013A & Tank Vault & \#32 & 26.8 & $\mathrm{U}$ & $\mathrm{R}$ & HCJ-164-08 \\
\hline Acrolein & E04808001013A & Pump Pit & $\# 3$ & 10.6 & $\mathrm{U}$ & $\mathrm{R}$ & HCJ-164-08 \\
\hline Acrolein & E04808002013A & Pump Pit & $\# 12$ & 10.7 & $\mathrm{U}$ & $\mathrm{R}$ & HCJ-164-08 \\
\hline Acrolein & E04808003013A & Pump Pit & $\# 16$ & 11 & $\mathrm{U}$ & $\mathrm{R}$ & HCJ-164-08 \\
\hline Acrolein & E04808004013A & Pump Pit & \#18 & 10.6 & $\mathrm{U}$ & $\mathrm{R}$ & HCJ-164-08 \\
\hline Acrolein & E04808005013A & Pump Pit & \#23 & 10.4 & $\mathrm{U}$ & $\mathrm{R}$ & HCJ-164-08 \\
\hline Acrolein & E04808006013A & Tank Vault & $\# 8$ & 11 & $\mathrm{U}$ & $\mathrm{R}$ & HCJ-164-08 \\
\hline Acrolein & E04808007013A & Tank Vault & $\# 9$ & 10.9 & $\mathrm{U}$ & $\mathrm{R}$ & HCJ-164-08 \\
\hline Acrolein & E04808008013A & Tank Vault & $\# 15$ & 10.7 & $\mathrm{U}$ & $\mathrm{R}$ & HCJ-164-08 \\
\hline Acrolein & E04808009013A & Tank Vault & $\# 24$ & 11 & $\mathrm{U}$ & $\mathrm{R}$ & HCJ-164-08 \\
\hline Acrolein & E04808010013A & Tank Vault & \#32 & 10.7 & $\mathrm{U}$ & $\mathrm{R}$ & HCJ-164-08 \\
\hline Acrylonitrile & E04808001013A & Pump Pit & \#3 & 5.3 & $\mathrm{U}$ & & HCJ-164-08 \\
\hline Acrylonitrile & E04808002013A & Pump Pit & $\# 12$ & 5.36 & $\mathrm{U}$ & & HCJ-164-08 \\
\hline Acrylonitrile & E04808003013A & Pump Pit & \#16 & 5.5 & $\mathrm{U}$ & & HCJ-164-08 \\
\hline Acrylonitrile & E04808004013A & Pump Pit & $\# 18$ & 5.28 & $\mathrm{U}$ & & HCJ-164-08 \\
\hline Acrylonitrile & E04808005013A & Pump Pit & $\# 23$ & 5.22 & $\mathrm{U}$ & & HCJ-164-08 \\
\hline Acrylonitrile & E04808006013A & Tank Vault & $\# 8$ & 5.5 & $\mathrm{U}$ & & HCJ-164-08 \\
\hline Acrylonitrile & E04808007013A & Tank Vault & $\# 9$ & 5.44 & $\mathrm{U}$ & & HCJ-164-08 \\
\hline Acrylonitrile & E04808008013A & Tank Vault & $\# 15$ & 5.34 & $\mathrm{U}$ & & HCJ-164-08 \\
\hline Acrylonitrile & E04808009013A & Tank Vault & $\# 24$ & 5.5 & $\mathrm{U}$ & & HCJ-164-08 \\
\hline Acrylonitrile & E04808010013A & Tank Vault & \#32 & 5.36 & $\mathrm{U}$ & & HCJ-164-08 \\
\hline Allyl chloride & E04808001013A & Pump Pit & $\# 3$ & 5.3 & $\mathrm{U}$ & & HCJ-164-08 \\
\hline Allyl chloride & E04808002013A & Pump Pit & $\# 12$ & 5.36 & $\mathrm{U}$ & & HCJ-164-08 \\
\hline Allyl chloride & E04808003013A & Pump Pit & $\# 16$ & 5.5 & $\mathrm{U}$ & & HCJ-164-08 \\
\hline Allyl chloride & E04808004013A & Pump Pit & \#18 & 5.28 & $\mathrm{U}$ & & HCJ-164-08 \\
\hline Allyl chloride & E04808005013A & Pump Pit & $\# 23$ & 5.22 & $\mathrm{U}$ & & HCJ-164-08 \\
\hline Allyl chloride & E04808006013A & Tank Vault & $\# 8$ & 5.5 & $\mathrm{U}$ & & HCJ-164-08 \\
\hline Allyl chloride & E04808007013A & Tank Vault & $\# 9$ & 5.44 & $\mathrm{U}$ & & HCJ-164-08 \\
\hline Allyl chloride & E04808008013A & Tank Vault & $\# 15$ & 5.34 & $\mathrm{U}$ & & HCJ-164-08 \\
\hline
\end{tabular}


Table G-3. (continued).

\begin{tabular}{|c|c|c|c|c|c|c|c|}
\hline Compound & $\begin{array}{c}\text { Field Sample } \\
\text { Number }\end{array}$ & Location & Grid & $\begin{array}{c}\text { Sample } \\
\text { Result } \\
(\mu \mathrm{g} / \mathrm{kg})\end{array}$ & $\begin{array}{l}\text { Result } \\
\text { Qual. }\end{array}$ & $\begin{array}{l}\text { Val. } \\
\text { Flag }\end{array}$ & $\begin{array}{c}\text { L\&V Report } \\
\text { Number }\end{array}$ \\
\hline Allyl chloride & E04808009013A & Tank Vault & $\# 24$ & 5.5 & $\mathrm{U}$ & & HCJ-164-08 \\
\hline Allyl chloride & E04808010013A & Tank Vault & \#32 & 5.36 & $\mathrm{U}$ & & HCJ-164-08 \\
\hline Benzene & E04808001013A & Pump Pit & $\# 3$ & 1.06 & $\mathrm{U}$ & & HCJ-164-08 \\
\hline Benzene & E04808002013A & Pump Pit & $\# 12$ & 1.07 & $\mathrm{U}$ & & HCJ-164-08 \\
\hline Benzene & E04808003013A & Pump Pit & $\# 16$ & 1.1 & $\mathrm{U}$ & & HCJ-164-08 \\
\hline Benzene & E04808004013A & Pump Pit & $\# 18$ & 1.06 & $\mathrm{U}$ & & HCJ-164-08 \\
\hline Benzene & E04808005013A & Pump Pit & \#23 & 1.04 & $\mathrm{U}$ & & HCJ-164-08 \\
\hline Benzene & E04808006013A & Tank Vault & $\# 8$ & 1.1 & $\mathrm{U}$ & & HCJ-164-08 \\
\hline Benzene & E04808007013A & Tank Vault & $\# 9$ & 1.09 & $\mathrm{U}$ & & HCJ-164-08 \\
\hline Benzene & E04808008013A & Tank Vault & $\# 15$ & 1.07 & $\mathrm{U}$ & & HCJ-164-08 \\
\hline Benzene & E04808009013A & Tank Vault & $\# 24$ & 1.1 & $\mathrm{U}$ & & HCJ-164-08 \\
\hline Benzene & E04808010013A & Tank Vault & \#32 & 1.07 & $\mathrm{U}$ & & HCJ-164-08 \\
\hline Bromodichloromethane & E04808001013A & Pump Pit & $\# 3$ & 1.06 & $\mathrm{U}$ & & HCJ-164-08 \\
\hline Bromodichloromethane & E04808002013A & Pump Pit & $\# 12$ & 1.07 & $\mathrm{U}$ & & HCJ-164-08 \\
\hline Bromodichloromethane & E04808003013A & Pump Pit & $\# 16$ & 1.1 & $\mathrm{U}$ & & HCJ-164-08 \\
\hline Bromodichloromethane & E04808004013A & Pump Pit & $\# 18$ & 1.06 & $\mathrm{U}$ & & HCJ-164-08 \\
\hline Bromodichloromethane & E04808005013A & Pump Pit & $\# 23$ & 1.04 & $\mathrm{U}$ & & HCJ-164-08 \\
\hline Bromodichloromethane & E04808006013A & Tank Vault & $\# 8$ & 1.1 & $\mathrm{U}$ & & HCJ-164-08 \\
\hline Bromodichloromethane & E04808007013A & Tank Vault & $\# 9$ & 1.09 & $\mathrm{U}$ & & HCJ-164-08 \\
\hline Bromodichloromethane & E04808008013A & Tank Vault & $\# 15$ & 1.07 & $\mathrm{U}$ & & HCJ-164-08 \\
\hline Bromodichloromethane & E04808009013A & Tank Vault & $\# 24$ & 1.1 & $\mathrm{U}$ & & HCJ-164-08 \\
\hline Bromodichloromethane & E04808010013A & Tank Vault & \#32 & 1.07 & $\mathrm{U}$ & & HCJ-164-08 \\
\hline Bromoform & E04808001013A & Pump Pit & $\# 3$ & 1.06 & $\mathrm{U}$ & & HCJ-164-08 \\
\hline Bromoform & E04808002013A & Pump Pit & $\# 12$ & 1.07 & $\mathrm{U}$ & & HCJ-164-08 \\
\hline Bromoform & E04808003013A & Pump Pit & $\# 16$ & 1.1 & $\mathrm{U}$ & & HCJ-164-08 \\
\hline Bromoform & E04808004013A & Pump Pit & $\# 18$ & 1.06 & $\mathrm{U}$ & & HCJ-164-08 \\
\hline Bromoform & E04808005013A & Pump Pit & $\# 23$ & 1.04 & $\mathrm{U}$ & & HCJ-164-08 \\
\hline Bromoform & E04808006013A & Tank Vault & $\# 8$ & 1.1 & $\mathrm{U}$ & & HCJ-164-08 \\
\hline Bromoform & E04808007013A & Tank Vault & $\# 9$ & 1.09 & $\mathrm{U}$ & & HCJ-164-08 \\
\hline Bromoform & E04808008013A & Tank Vault & $\# 15$ & 1.07 & $\mathrm{U}$ & & HCJ-164-08 \\
\hline Bromoform & E04808009013A & Tank Vault & $\# 24$ & 1.1 & $\mathrm{U}$ & & HCJ-164-08 \\
\hline Bromoform & E04808010013A & Tank Vault & \#32 & 1.07 & $\mathrm{U}$ & & HCJ-164-08 \\
\hline Bromomethane & E04808001013A & Pump Pit & $\# 3$ & 1.06 & $\mathrm{U}$ & & HCJ-164-08 \\
\hline Bromomethane & E04808002013A & Pump Pit & $\# 12$ & 1.07 & $\mathrm{U}$ & & HCJ-164-08 \\
\hline Bromomethane & E04808003013A & Pump Pit & $\# 16$ & 1.1 & $\mathrm{U}$ & & HCJ-164-08 \\
\hline Bromomethane & E04808004013A & Pump Pit & $\# 18$ & 1.06 & $\mathrm{U}$ & & HCJ-164-08 \\
\hline Bromomethane & E04808005013A & Pump Pit & \#23 & 1.04 & $\mathrm{U}$ & & HCJ-164-08 \\
\hline Bromomethane & E04808006013A & Tank Vault & $\# 8$ & 1.1 & $\mathrm{U}$ & & HCJ-164-08 \\
\hline Bromomethane & E04808007013A & Tank Vault & $\# 9$ & 1.09 & $\mathrm{U}$ & & HCJ-164-08 \\
\hline Bromomethane & E04808008013A & Tank Vault & $\# 15$ & 1.07 & $\mathrm{U}$ & & HCJ-164-08 \\
\hline Bromomethane & E04808009013A & Tank Vault & $\# 24$ & 1.1 & $\mathrm{U}$ & & HCJ-164-08 \\
\hline Bromomethane & E04808010013A & Tank Vault & \#32 & 1.07 & $\mathrm{U}$ & & HCJ-164-08 \\
\hline Carbon disulfide & E04808001013A & Pump Pit & $\# 3$ & 5.3 & $\mathrm{U}$ & & HCJ-164-08 \\
\hline Carbon disulfide & E04808002013A & Pump Pit & $\# 12$ & 5.36 & $\mathrm{U}$ & & HCJ-164-08 \\
\hline Carbon disulfide & E04808003013A & Pump Pit & $\# 16$ & 5.5 & $\mathrm{U}$ & & HCJ-164-08 \\
\hline Carbon disulfide & E04808004013A & Pump Pit & $\# 18$ & 5.28 & $\mathrm{U}$ & & HCJ-164-08 \\
\hline Carbon disulfide & E04808005013A & Pump Pit & \#23 & 5.22 & $\mathrm{U}$ & & HCJ-164-08 \\
\hline Carbon disulfide & E04808006013A & Tank Vault & $\# 8$ & 5.5 & $\mathrm{U}$ & & HCJ-164-08 \\
\hline
\end{tabular}


Table G-3. (continued).

\begin{tabular}{|c|c|c|c|c|c|c|c|}
\hline Compound & $\begin{array}{l}\text { Field Sample } \\
\text { Number }\end{array}$ & Location & Grid & $\begin{array}{c}\text { Sample } \\
\text { Result } \\
(\mu \mathrm{g} / \mathrm{kg})\end{array}$ & $\begin{array}{l}\text { Result } \\
\text { Qual. }\end{array}$ & $\begin{array}{l}\text { Val. } \\
\text { Flag }\end{array}$ & $\begin{array}{l}\text { L\&V Report } \\
\text { Number }\end{array}$ \\
\hline Carbon disulfide & E04808007013A & Tank Vault & $\# 9$ & 5.44 & $\mathrm{U}$ & & HCJ-164-08 \\
\hline Carbon disulfide & E04808008013A & Tank Vault & $\# 15$ & 5.34 & $\mathrm{U}$ & & HCJ-164-08 \\
\hline Carbon disulfide & E04808009013A & Tank Vault & $\# 24$ & 5.5 & $\mathrm{U}$ & & HCJ-164-08 \\
\hline Carbon disulfide & E04808010013A & Tank Vault & \#32 & 5.36 & $\mathrm{U}$ & & HCJ-164-08 \\
\hline Carbon tetrachloride & E04808001013A & Pump Pit & $\# 3$ & 1.06 & $\mathrm{U}$ & & HCJ-164-08 \\
\hline Carbon tetrachloride & E04808002013A & Pump Pit & $\# 12$ & 1.07 & $\mathrm{U}$ & & HCJ-164-08 \\
\hline Carbon tetrachloride & E04808003013A & Pump Pit & $\# 16$ & 1.1 & $\mathrm{U}$ & & HCJ-164-08 \\
\hline Carbon tetrachloride & E04808004013A & Pump Pit & $\# 18$ & 1.06 & $\mathrm{U}$ & & HCJ-164-08 \\
\hline Carbon tetrachloride & E04808005013A & Pump Pit & $\# 23$ & 1.04 & $\mathrm{U}$ & & HCJ-164-08 \\
\hline Carbon tetrachloride & E04808006013A & Tank Vault & \#8 & 1.1 & $\mathrm{U}$ & & HCJ-164-08 \\
\hline Carbon tetrachloride & E04808007013A & Tank Vault & $\# 9$ & 1.09 & $\mathrm{U}$ & & HCJ-164-08 \\
\hline Carbon tetrachloride & E04808008013A & Tank Vault & $\# 15$ & 1.07 & $\mathrm{U}$ & & HCJ-164-08 \\
\hline Carbon tetrachloride & E04808009013A & Tank Vault & \#24 & 1.1 & $\mathrm{U}$ & & HCJ-164-08 \\
\hline Carbon tetrachloride & E04808010013A & Tank Vault & \#32 & 1.07 & $\mathrm{U}$ & & HCJ-164-08 \\
\hline Chlorobenzene & E04808001013A & Pump Pit & \#3 & 1.06 & $\mathrm{U}$ & & HCJ-164-08 \\
\hline Chlorobenzene & E04808002013A & Pump Pit & $\# 12$ & 1.07 & $\mathrm{U}$ & & HCJ-164-08 \\
\hline Chlorobenzene & E04808003013A & Pump Pit & $\# 16$ & 1.1 & $\mathrm{U}$ & & HCJ-164-08 \\
\hline Chlorobenzene & E04808004013A & Pump Pit & $\# 18$ & 1.06 & $\mathrm{U}$ & & HCJ-164-08 \\
\hline Chlorobenzene & E04808005013A & Pump Pit & $\# 23$ & 1.04 & $\mathrm{U}$ & & HCJ-164-08 \\
\hline Chlorobenzene & E04808006013A & Tank Vault & $\# 8$ & 1.1 & $\mathrm{U}$ & & HCJ-164-08 \\
\hline Chlorobenzene & E04808007013A & Tank Vault & $\# 9$ & 1.09 & $\mathrm{U}$ & & HCJ-164-08 \\
\hline Chlorobenzene & E04808008013A & Tank Vault & $\# 15$ & 1.07 & $\mathrm{U}$ & & HCJ-164-08 \\
\hline Chlorobenzene & E04808009013A & Tank Vault & \#24 & 1.1 & $\mathrm{U}$ & & HCJ-164-08 \\
\hline Chlorobenzene & E04808010013A & Tank Vault & \#32 & 1.07 & $\mathrm{U}$ & & HCJ-164-08 \\
\hline Chloroethane & E04808001013A & Pump Pit & $\# 3$ & 1.06 & $\mathrm{U}$ & & HCJ-164-08 \\
\hline Chloroethane & E04808002013A & Pump Pit & $\# 12$ & 1.07 & $\mathrm{U}$ & & HCJ-164-08 \\
\hline Chloroethane & E04808003013A & Pump Pit & $\# 16$ & 1.1 & $\mathrm{U}$ & & HCJ-164-08 \\
\hline Chloroethane & E04808004013A & Pump Pit & $\# 18$ & 1.06 & $\mathrm{U}$ & & HCJ-164-08 \\
\hline Chloroethane & E04808005013A & Pump Pit & \#23 & 1.04 & $\mathrm{U}$ & & HCJ-164-08 \\
\hline Chloroethane & E04808006013A & Tank Vault & $\# 8$ & 1.1 & $\mathrm{U}$ & & HCJ-164-08 \\
\hline Chloroethane & E04808007013A & Tank Vault & $\# 9$ & 1.09 & $\mathrm{U}$ & & HCJ-164-08 \\
\hline Chloroethane & E04808008013A & Tank Vault & $\# 15$ & 1.07 & $\mathrm{U}$ & & HCJ-164-08 \\
\hline Chloroethane & E04808009013A & Tank Vault & \#24 & 1.1 & $\mathrm{U}$ & & HCJ-164-08 \\
\hline Chloroethane & E04808010013A & Tank Vault & \#32 & 1.07 & $\mathrm{U}$ & & HCJ-164-08 \\
\hline Chloroform & E04808001013A & Pump Pit & $\# 3$ & 1.9 & & & HCJ-164-08 \\
\hline Chloroform & E04808002013A & Pump Pit & $\# 12$ & 1.07 & $\mathrm{U}$ & & HCJ-164-08 \\
\hline Chloroform & E04808003013A & Pump Pit & $\# 16$ & 0.853 & $\mathrm{~J}$ & & HCJ-164-08 \\
\hline Chloroform & E04808004013A & Pump Pit & $\# 18$ & 0.934 & $\mathrm{~J}$ & & HCJ-164-08 \\
\hline Chloroform & E04808005013A & Pump Pit & $\# 23$ & 1.72 & & & HCJ-164-08 \\
\hline Chloroform & E04808006013A & Tank Vault & $\# 8$ & 3.89 & & & HCJ-164-08 \\
\hline Chloroform & E04808007013A & Tank Vault & $\# 9$ & 0.7 & $\mathrm{~J}$ & & HCJ-164-08 \\
\hline Chloroform & E04808008013A & Tank Vault & $\# 15$ & 2.35 & & & HCJ-164-08 \\
\hline Chloroform & E04808009013A & Tank Vault & $\# 24$ & 0.469 & $\mathrm{~J}$ & & HCJ-164-08 \\
\hline Chloroform & E04808010013A & Tank Vault & \#32 & 4.12 & & & HCJ-164-08 \\
\hline Chloromethane & E04808001013A & Pump Pit & $\# 3$ & 1.06 & $\mathrm{U}$ & & HCJ-164-08 \\
\hline Chloromethane & E04808002013A & Pump Pit & $\# 12$ & 1.07 & $\mathrm{U}$ & & HCJ-164-08 \\
\hline Chloromethane & E04808003013A & Pump Pit & $\# 16$ & 1.1 & $\mathrm{U}$ & & HCJ-164-08 \\
\hline Chloromethane & E04808004013A & Pump Pit & $\# 18$ & 1.06 & $\mathrm{U}$ & & HCJ-164-08 \\
\hline
\end{tabular}


Table G-3. (continued).

\begin{tabular}{|c|c|c|c|c|c|c|c|}
\hline Compound & $\begin{array}{c}\text { Field Sample } \\
\text { Number }\end{array}$ & Location & Grid & $\begin{array}{c}\text { Sample } \\
\text { Result } \\
(\mu \mathrm{g} / \mathrm{kg})\end{array}$ & $\begin{array}{l}\text { Result } \\
\text { Qual. }\end{array}$ & $\begin{array}{l}\text { Val. } \\
\text { Flag }\end{array}$ & $\begin{array}{c}\text { L\&V Report } \\
\text { Number }\end{array}$ \\
\hline Chloromethane & E04808005013A & Pump Pit & $\# 23$ & 1.04 & $\mathrm{U}$ & & HCJ-164-08 \\
\hline Chloromethane & E04808006013A & Tank Vault & $\# 8$ & 1.1 & $\mathrm{U}$ & & HCJ-164-08 \\
\hline Chloromethane & E04808007013A & Tank Vault & $\# 9$ & 1.09 & $\mathrm{U}$ & & HCJ-164-08 \\
\hline Chloromethane & E04808008013A & Tank Vault & $\# 15$ & 1.07 & $\mathrm{U}$ & & HCJ-164-08 \\
\hline Chloromethane & E04808009013A & Tank Vault & $\# 24$ & 1.1 & $\mathrm{U}$ & & HCJ-164-08 \\
\hline Chloromethane & E04808010013A & Tank Vault & \#32 & 1.07 & $\mathrm{U}$ & & HCJ-164-08 \\
\hline cis-1,2-Dichloroethene & E04808001013A & Pump Pit & $\# 3$ & 1.06 & $\mathrm{U}$ & & HCJ-164-08 \\
\hline cis-1,2-Dichloroethene & E04808002013A & Pump Pit & $\# 12$ & 1.07 & $\mathrm{U}$ & & HCJ-164-08 \\
\hline cis-1,2-Dichloroethene & E04808003013A & Pump Pit & \#16 & 1.1 & $\mathrm{U}$ & & HCJ-164-08 \\
\hline cis-1,2-Dichloroethene & E04808004013A & Pump Pit & $\# 18$ & 1.06 & $\mathrm{U}$ & & HCJ-164-08 \\
\hline cis-1,2-Dichloroethene & E04808005013A & Pump Pit & \#23 & 1.04 & $\mathrm{U}$ & & HCJ-164-08 \\
\hline cis-1,2-Dichloroethene & E04808006013A & Tank Vault & $\# 8$ & 1.1 & $\mathrm{U}$ & & HCJ-164-08 \\
\hline cis-1,2-Dichloroethene & E04808007013A & Tank Vault & $\# 9$ & 1.09 & $\mathrm{U}$ & & HCJ-164-08 \\
\hline cis-1,2-Dichloroethene & E04808008013A & Tank Vault & $\# 15$ & 1.07 & $\mathrm{U}$ & & HCJ-164-08 \\
\hline cis-1,2-Dichloroethene & E04808009013A & Tank Vault & $\# 24$ & 1.1 & $\mathrm{U}$ & & HCJ-164-08 \\
\hline cis-1,2-Dichloroethene & E04808010013A & Tank Vault & \#32 & 1.07 & $\mathrm{U}$ & & HCJ-164-08 \\
\hline cis-1,3-Dichloropropylene & E04808001013A & Pump Pit & $\# 3$ & 1.06 & $\mathrm{U}$ & & HCJ-164-08 \\
\hline cis-1,3-Dichloropropylene & E04808002013A & Pump Pit & \#12 & 1.07 & $\mathrm{U}$ & & HCJ-164-08 \\
\hline cis-1,3-Dichloropropylene & E04808003013A & Pump Pit & $\# 16$ & 1.1 & $\mathrm{U}$ & & HCJ-164-08 \\
\hline cis-1,3-Dichloropropylene & E04808004013A & Pump Pit & $\# 18$ & 1.06 & $\mathrm{U}$ & & HCJ-164-08 \\
\hline cis-1,3-Dichloropropylene & E04808005013A & Pump Pit & \#23 & 1.04 & $\mathrm{U}$ & & HCJ-164-08 \\
\hline cis-1,3-Dichloropropylene & E04808006013A & Tank Vault & $\# 8$ & 1.1 & $\mathrm{U}$ & & HCJ-164-08 \\
\hline cis-1,3-Dichloropropylene & E04808007013A & Tank Vault & $\# 9$ & 1.09 & $\mathrm{U}$ & & HCJ-164-08 \\
\hline cis-1,3-Dichloropropylene & E04808008013A & Tank Vault & $\# 15$ & 1.07 & $\mathrm{U}$ & & HCJ-164-08 \\
\hline cis-1,3-Dichloropropylene & E04808009013A & Tank Vault & $\# 24$ & 1.1 & $\mathrm{U}$ & & HCJ-164-08 \\
\hline cis-1,3-Dichloropropylene & E04808010013A & Tank Vault & \#32 & 1.07 & $\mathrm{U}$ & & HCJ-164-08 \\
\hline Dibromochloromethane & E04808001013A & Pump Pit & $\# 3$ & 1.06 & $\mathrm{U}$ & & HCJ-164-08 \\
\hline Dibromochloromethane & E04808002013A & Pump Pit & $\# 12$ & 1.07 & $\mathrm{U}$ & & HCJ-164-08 \\
\hline Dibromochloromethane & E04808003013A & Pump Pit & $\# 16$ & 1.1 & $\mathrm{U}$ & & HCJ-164-08 \\
\hline Dibromochloromethane & E04808004013A & Pump Pit & $\# 18$ & 1.06 & $\mathrm{U}$ & & HCJ-164-08 \\
\hline Dibromochloromethane & E04808005013A & Pump Pit & $\# 23$ & 1.04 & $\mathrm{U}$ & & HCJ-164-08 \\
\hline Dibromochloromethane & E04808006013A & Tank Vault & $\# 8$ & 1.1 & $\mathrm{U}$ & & HCJ-164-08 \\
\hline Dibromochloromethane & E04808007013A & Tank Vault & $\# 9$ & 1.09 & $\mathrm{U}$ & & HCJ-164-08 \\
\hline Dibromochloromethane & E04808008013A & Tank Vault & $\# 15$ & 1.07 & $\mathrm{U}$ & & HCJ-164-08 \\
\hline Dibromochloromethane & E04808009013A & Tank Vault & $\# 24$ & 1.1 & $\mathrm{U}$ & & HCJ-164-08 \\
\hline Dibromochloromethane & E04808010013A & Tank Vault & \#32 & 1.07 & $\mathrm{U}$ & & HCJ-164-08 \\
\hline Dibromomethane & E04808001013A & Pump Pit & $\# 3$ & 1.06 & $\mathrm{U}$ & & HCJ-164-08 \\
\hline Dibromomethane & E04808002013A & Pump Pit & $\# 12$ & 1.07 & $\mathrm{U}$ & & HCJ-164-08 \\
\hline Dibromomethane & E04808003013A & Pump Pit & $\# 16$ & 1.1 & $\mathrm{U}$ & & HCJ-164-08 \\
\hline Dibromomethane & E04808004013A & Pump Pit & $\# 18$ & 1.06 & $\mathrm{U}$ & & HCJ-164-08 \\
\hline Dibromomethane & E04808005013A & Pump Pit & \#23 & 1.04 & $\mathrm{U}$ & & HCJ-164-08 \\
\hline Dibromomethane & E04808006013A & Tank Vault & $\# 8$ & 1.1 & $\mathrm{U}$ & & HCJ-164-08 \\
\hline Dibromomethane & E04808007013A & Tank Vault & $\# 9$ & 1.09 & $\mathrm{U}$ & & HCJ-164-08 \\
\hline Dibromomethane & E04808008013A & Tank Vault & $\# 15$ & 1.07 & $\mathrm{U}$ & & HCJ-164-08 \\
\hline Dibromomethane & E04808009013A & Tank Vault & $\# 24$ & 1.1 & $\mathrm{U}$ & & HCJ-164-08 \\
\hline Dibromomethane & E04808010013A & Tank Vault & \#32 & 1.07 & $\mathrm{U}$ & & HCJ-164-08 \\
\hline Dichlorodifluoromethane & E04808001013A & Pump Pit & $\# 3$ & 1.06 & $\mathrm{U}$ & & HCJ-164-08 \\
\hline Dichlorodifluoromethane & E04808002013A & Pump Pit & $\# 12$ & 1.07 & $\mathrm{U}$ & & HCJ-164-08 \\
\hline
\end{tabular}


Table G-3. (continued).

\begin{tabular}{|c|c|c|c|c|c|c|c|}
\hline Compound & $\begin{array}{c}\text { Field Sample } \\
\text { Number }\end{array}$ & Location & Grid & $\begin{array}{c}\text { Sample } \\
\text { Result } \\
(\mu \mathrm{g} / \mathrm{kg})\end{array}$ & $\begin{array}{l}\text { Result } \\
\text { Qual. }\end{array}$ & $\begin{array}{l}\text { Val. } \\
\text { Flag }\end{array}$ & $\begin{array}{c}\text { L\&V Report } \\
\text { Number }\end{array}$ \\
\hline Dichlorodifluoromethane & E04808003013A & Pump Pit & $\# 16$ & 1.1 & $\mathrm{U}$ & & HCJ-164-08 \\
\hline Dichlorodifluoromethane & E04808004013A & Pump Pit & $\# 18$ & 1.06 & $\mathrm{U}$ & & HCJ-164-08 \\
\hline Dichlorodifluoromethane & E04808005013A & Pump Pit & $\# 23$ & 1.04 & $\mathrm{U}$ & & HCJ-164-08 \\
\hline Dichlorodifluoromethane & E04808006013A & Tank Vault & $\# 8$ & 1.1 & $\mathrm{U}$ & & HCJ-164-08 \\
\hline Dichlorodifluoromethane & E04808007013A & Tank Vault & $\# 9$ & 1.09 & $\mathrm{U}$ & & HCJ-164-08 \\
\hline Dichlorodifluoromethane & E04808008013A & Tank Vault & $\# 15$ & 1.07 & $\mathrm{U}$ & & HCJ-164-08 \\
\hline Dichlorodifluoromethane & E04808009013A & Tank Vault & $\# 24$ & 1.1 & $\mathrm{U}$ & & HCJ-164-08 \\
\hline Dichlorodifluoromethane & E04808010013A & Tank Vault & \#32 & 1.07 & $\mathrm{U}$ & & HCJ-164-08 \\
\hline Ethyl methacrylate & E04808001013A & Pump Pit & $\# 3$ & 5.3 & $\mathrm{U}$ & & HCJ-164-08 \\
\hline Ethyl methacrylate & E04808002013A & Pump Pit & $\# 12$ & 5.36 & $\mathrm{U}$ & & HCJ-164-08 \\
\hline Ethyl methacrylate & E04808003013A & Pump Pit & $\# 16$ & 5.5 & $\mathrm{U}$ & & HCJ-164-08 \\
\hline Ethyl methacrylate & E04808004013A & Pump Pit & $\# 18$ & 5.28 & $\mathrm{U}$ & & HCJ-164-08 \\
\hline Ethyl methacrylate & E04808005013A & Pump Pit & $\# 23$ & 5.22 & $\mathrm{U}$ & & HCJ-164-08 \\
\hline Ethyl methacrylate & E04808006013A & Tank Vault & $\# 8$ & 5.5 & $\mathrm{U}$ & & HCJ-164-08 \\
\hline Ethyl methacrylate & E04808007013A & Tank Vault & $\# 9$ & 5.44 & $\mathrm{U}$ & & HCJ-164-08 \\
\hline Ethyl methacrylate & E04808008013A & Tank Vault & $\# 15$ & 5.34 & $\mathrm{U}$ & & HCJ-164-08 \\
\hline Ethyl methacrylate & E04808009013A & Tank Vault & $\# 24$ & 5.5 & $\mathrm{U}$ & & HCJ-164-08 \\
\hline Ethyl methacrylate & E04808010013A & Tank Vault & $\# 32$ & 5.36 & $\mathrm{U}$ & & HCJ-164-08 \\
\hline Ethylbenzene & E04808001013A & Pump Pit & $\# 3$ & 1.06 & $\mathrm{U}$ & & HCJ-164-08 \\
\hline Ethylbenzene & E04808002013A & Pump Pit & $\# 12$ & 1.07 & $\mathrm{U}$ & & HCJ-164-08 \\
\hline Ethylbenzene & E04808003013A & Pump Pit & $\# 16$ & 1.1 & $\mathrm{U}$ & & HCJ-164-08 \\
\hline Ethylbenzene & E04808004013A & Pump Pit & $\# 18$ & 1.06 & $\mathrm{U}$ & & HCJ-164-08 \\
\hline Ethylbenzene & E04808005013A & Pump Pit & $\# 23$ & 1.04 & $\mathrm{U}$ & & HCJ-164-08 \\
\hline Ethylbenzene & E04808006013A & Tank Vault & $\# 8$ & 1.1 & $\mathrm{U}$ & & HCJ-164-08 \\
\hline Ethylbenzene & E04808007013A & Tank Vault & $\# 9$ & 1.09 & $\mathrm{U}$ & & HCJ-164-08 \\
\hline Ethylbenzene & E04808008013A & Tank Vault & $\# 15$ & 1.07 & $\mathrm{U}$ & & HCJ-164-08 \\
\hline Ethylbenzene & E04808009013A & Tank Vault & $\# 24$ & 1.1 & $\mathrm{U}$ & & HCJ-164-08 \\
\hline Ethylbenzene & E04808010013A & Tank Vault & $\# 32$ & 1.07 & $\mathrm{U}$ & & HCJ-164-08 \\
\hline Iodomethane & E04808001013A & Pump Pit & $\# 3$ & 5.3 & $\mathrm{U}$ & & HCJ-164-08 \\
\hline Iodomethane & E04808002013A & Pump Pit & $\# 12$ & 5.36 & $\mathrm{U}$ & & HCJ-164-08 \\
\hline Iodomethane & E04808003013A & Pump Pit & $\# 16$ & 5.5 & $\mathrm{U}$ & & HCJ-164-08 \\
\hline Iodomethane & E04808004013A & Pump Pit & $\# 18$ & 5.28 & $\mathrm{U}$ & & HCJ-164-08 \\
\hline Iodomethane & E04808005013A & Pump Pit & $\# 23$ & 5.22 & $\mathrm{U}$ & & HCJ-164-08 \\
\hline Iodomethane & E04808006013A & Tank Vault & $\# 8$ & 5.5 & $\mathrm{U}$ & & HCJ-164-08 \\
\hline Iodomethane & E04808007013A & Tank Vault & $\# 9$ & 5.44 & $\mathrm{U}$ & & HCJ-164-08 \\
\hline Iodomethane & E04808008013A & Tank Vault & $\# 15$ & 5.34 & $\mathrm{U}$ & & HCJ-164-08 \\
\hline Iodomethane & E04808009013A & Tank Vault & $\# 24$ & 5.5 & $\mathrm{U}$ & & HCJ-164-08 \\
\hline Iodomethane & E04808010013A & Tank Vault & $\# 32$ & 5.36 & $\mathrm{U}$ & & HCJ-164-08 \\
\hline Isobutyl alcohol & E04808001013A & Pump Pit & $\# 3$ & 53 & $\mathrm{U}$ & $\mathrm{R}$ & HCJ-164-08 \\
\hline Isobutyl alcohol & E04808002013A & Pump Pit & $\# 12$ & 53.6 & $\mathrm{U}$ & $\mathrm{R}$ & HCJ-164-08 \\
\hline Isobutyl alcohol & E04808003013A & Pump Pit & $\# 16$ & 55 & $\mathrm{U}$ & $\mathrm{R}$ & HCJ-164-08 \\
\hline Isobutyl alcohol & E04808004013A & Pump Pit & $\# 18$ & 52.8 & $\mathrm{U}$ & $\mathrm{R}$ & HCJ-164-08 \\
\hline Isobutyl alcohol & E04808005013A & Pump Pit & $\# 23$ & 52.2 & $\mathrm{U}$ & $\mathrm{R}$ & HCJ-164-08 \\
\hline Isobutyl alcohol & E04808006013A & Tank Vault & $\# 8$ & 55 & $\mathrm{U}$ & $\mathrm{R}$ & HCJ-164-08 \\
\hline Isobutyl alcohol & E04808007013A & Tank Vault & $\# 9$ & 54.4 & $\mathrm{U}$ & $\mathrm{R}$ & HCJ-164-08 \\
\hline Isobutyl alcohol & E04808008013A & Tank Vault & $\# 15$ & 53.4 & $\mathrm{U}$ & $\mathrm{R}$ & HCJ-164-08 \\
\hline Isobutyl alcohol & E04808009013A & Tank Vault & $\# 24$ & 55 & $\mathrm{U}$ & $\mathrm{R}$ & HCJ-164-08 \\
\hline Isobutyl alcohol & E04808010013A & Tank Vault & \#32 & 53.6 & $\mathrm{U}$ & $\mathrm{R}$ & HCJ-164-08 \\
\hline
\end{tabular}


Table G-3. (continued).

\begin{tabular}{|c|c|c|c|c|c|c|c|}
\hline Compound & $\begin{array}{l}\text { Field Sample } \\
\text { Number }\end{array}$ & Location & Grid & $\begin{array}{c}\text { Sample } \\
\text { Result } \\
(\mu \mathrm{g} / \mathrm{kg})\end{array}$ & $\begin{array}{l}\text { Result } \\
\text { Qual. }\end{array}$ & $\begin{array}{l}\text { Val. } \\
\text { Flag }\end{array}$ & $\begin{array}{l}\text { L\&V Report } \\
\text { Number }\end{array}$ \\
\hline Methacrylonitrile & E04808001013A & Pump Pit & $\# 3$ & 5.3 & $\mathrm{U}$ & & HCJ-164-08 \\
\hline Methacrylonitrile & E04808002013A & Pump Pit & \#12 & 5.36 & $\mathrm{U}$ & & HCJ-164-08 \\
\hline Methacrylonitrile & E04808003013A & Pump Pit & $\# 16$ & 5.5 & $\mathrm{U}$ & & HCJ-164-08 \\
\hline Methacrylonitrile & E04808004013A & Pump Pit & $\# 18$ & 5.28 & $\mathrm{U}$ & & HCJ-164-08 \\
\hline Methacrylonitrile & E04808005013A & Pump Pit & \#23 & 5.22 & $\mathrm{U}$ & & HCJ-164-08 \\
\hline Methacrylonitrile & E04808006013A & Tank Vault & $\# 8$ & 5.5 & $\mathrm{U}$ & & HCJ-164-08 \\
\hline Methacrylonitrile & E04808007013A & Tank Vault & $\# 9$ & 5.44 & $\mathrm{U}$ & & HCJ-164-08 \\
\hline Methacrylonitrile & E04808008013A & Tank Vault & $\# 15$ & 5.34 & $\mathrm{U}$ & & HCJ-164-08 \\
\hline Methacrylonitrile & E04808009013A & Tank Vault & $\# 24$ & 5.5 & $\mathrm{U}$ & & HCJ-164-08 \\
\hline Methacrylonitrile & E04808010013A & Tank Vault & \#32 & 5.36 & $\mathrm{U}$ & & HCJ-164-08 \\
\hline Methylene Chloride & E04808001013A & Pump Pit & $\# 3$ & 5.3 & $\mathrm{U}$ & & HCJ-164-08 \\
\hline Methylene Chloride & E04808002013A & Pump Pit & \#12 & 5.36 & $\mathrm{U}$ & & HCJ-164-08 \\
\hline Methylene Chloride & E04808003013A & Pump Pit & $\# 16$ & 5.5 & $\mathrm{U}$ & & HCJ-164-08 \\
\hline Methylene Chloride & E04808004013A & Pump Pit & $\# 18$ & 5.28 & $\mathrm{U}$ & & HCJ-164-08 \\
\hline Methylene Chloride & E04808005013A & Pump Pit & \#23 & 5.22 & $\mathrm{U}$ & & HCJ-164-08 \\
\hline Methylene Chloride & E04808006013A & Tank Vault & $\# 8$ & 2.8 & $\mathrm{~J}$ & & HCJ-164-08 \\
\hline Methylene Chloride & E04808007013A & Tank Vault & $\# 9$ & 5.44 & $\mathrm{U}$ & & HCJ-164-08 \\
\hline Methylene Chloride & E04808008013A & Tank Vault & $\# 15$ & 5.34 & $\mathrm{U}$ & & HCJ-164-08 \\
\hline Methylene Chloride & E04808009013A & Tank Vault & $\# 24$ & 5.5 & $\mathrm{U}$ & & HCJ-164-08 \\
\hline Methylene Chloride & E04808010013A & Tank Vault & \#32 & 2.87 & $\mathrm{~J}$ & & HCJ-164-08 \\
\hline Methylmethacrylate & E04808001013A & Pump Pit & $\# 3$ & 5.3 & $\mathrm{U}$ & & HCJ-164-08 \\
\hline Methylmethacrylate & E04808002013A & Pump Pit & $\# 12$ & 5.36 & $\mathrm{U}$ & & HCJ-164-08 \\
\hline Methylmethacrylate & E04808003013A & Pump Pit & $\# 16$ & 5.5 & $\mathrm{U}$ & & HCJ-164-08 \\
\hline Methylmethacrylate & E04808004013A & Pump Pit & \#18 & 5.28 & $\mathrm{U}$ & & HCJ-164-08 \\
\hline Methylmethacrylate & E04808005013A & Pump Pit & $\# 23$ & 5.22 & $\mathrm{U}$ & & HCJ-164-08 \\
\hline Methylmethacrylate & E04808006013A & Tank Vault & $\# 8$ & 5.5 & $\mathrm{U}$ & & HCJ-164-08 \\
\hline Methylmethacrylate & E04808007013A & Tank Vault & $\# 9$ & 5.44 & $\mathrm{U}$ & & HCJ-164-08 \\
\hline Methylmethacrylate & E04808008013A & Tank Vault & $\# 15$ & 5.34 & $\mathrm{U}$ & & HCJ-164-08 \\
\hline Methylmethacrylate & E04808009013A & Tank Vault & \#24 & 5.5 & $\mathrm{U}$ & & HCJ-164-08 \\
\hline Methylmethacrylate & E04808010013A & Tank Vault & \#32 & 5.36 & $\mathrm{U}$ & & HCJ-164-08 \\
\hline Propionitrile & E04808001013A & Pump Pit & \#3 & 5.3 & $\mathrm{U}$ & $\mathrm{R}$ & HCJ-164-08 \\
\hline Propionitrile & E04808002013A & Pump Pit & $\# 12$ & 5.36 & $\mathrm{U}$ & $\mathrm{R}$ & HCJ-164-08 \\
\hline Propionitrile & E04808003013A & Pump Pit & \#16 & 5.5 & $\mathrm{U}$ & $\mathrm{R}$ & HCJ-164-08 \\
\hline Propionitrile & E04808004013A & Pump Pit & $\# 18$ & 5.28 & $\mathrm{U}$ & $\mathrm{R}$ & HCJ-164-08 \\
\hline Propionitrile & E04808005013A & Pump Pit & $\# 23$ & 5.22 & $\mathrm{U}$ & $\mathrm{R}$ & HCJ-164-08 \\
\hline Propionitrile & E04808006013A & Tank Vault & $\# 8$ & 5.5 & $\mathrm{U}$ & $\mathrm{R}$ & HCJ-164-08 \\
\hline Propionitrile & E04808007013A & Tank Vault & $\# 9$ & 5.44 & $\mathrm{U}$ & $\mathrm{R}$ & HCJ-164-08 \\
\hline Propionitrile & E04808008013A & Tank Vault & $\# 15$ & 5.34 & $\mathrm{U}$ & $\mathrm{R}$ & HCJ-164-08 \\
\hline Propionitrile & E04808009013A & Tank Vault & $\# 24$ & 5.5 & $\mathrm{U}$ & $\mathrm{R}$ & HCJ-164-08 \\
\hline Propionitrile & E04808010013A & Tank Vault & \#32 & 5.36 & $\mathrm{U}$ & $\mathrm{R}$ & HCJ-164-08 \\
\hline Styrene & E04808001013A & Pump Pit & \#3 & 1.06 & $\mathrm{U}$ & & HCJ-164-08 \\
\hline Styrene & E04808002013A & Pump Pit & $\# 12$ & 1.07 & $\mathrm{U}$ & & HCJ-164-08 \\
\hline Styrene & E04808003013A & Pump Pit & \#16 & 1.1 & $\mathrm{U}$ & & HCJ-164-08 \\
\hline Styrene & E04808004013A & Pump Pit & $\# 18$ & 1.06 & $\mathrm{U}$ & & HCJ-164-08 \\
\hline Styrene & E04808005013A & Pump Pit & \#23 & 1.04 & $\mathrm{U}$ & & HCJ-164-08 \\
\hline Styrene & E04808006013A & Tank Vault & $\# 8$ & 1.1 & $\mathrm{U}$ & & HCJ-164-08 \\
\hline Styrene & E04808007013A & Tank Vault & $\# 9$ & 1.09 & $\mathrm{U}$ & & HCJ-164-08 \\
\hline Styrene & E04808008013A & Tank Vault & $\# 15$ & 1.07 & $\mathrm{U}$ & & HCJ-164-08 \\
\hline
\end{tabular}


Table G-3. (continued).

\begin{tabular}{|c|c|c|c|c|c|c|c|}
\hline Compound & $\begin{array}{l}\text { Field Sample } \\
\text { Number }\end{array}$ & Location & Grid & $\begin{array}{c}\text { Sample } \\
\text { Result } \\
(\mu \mathrm{g} / \mathrm{kg})\end{array}$ & $\begin{array}{l}\text { Result } \\
\text { Qual. }\end{array}$ & $\begin{array}{l}\text { Val. } \\
\text { Flag }\end{array}$ & $\begin{array}{l}\text { L\&V Report } \\
\text { Number }\end{array}$ \\
\hline Styrene & E04808009013A & Tank Vault & $\# 24$ & 1.1 & $\mathrm{U}$ & & HCJ-164-08 \\
\hline Styrene & E04808010013A & Tank Vault & \#32 & 1.07 & $\mathrm{U}$ & & HCJ-164-08 \\
\hline Tetrachloroethylene & E04808001013A & Pump Pit & $\# 3$ & 0.435 & $\mathrm{~J}$ & & HCJ-164-08 \\
\hline Tetrachloroethylene & E04808002013A & Pump Pit & $\# 12$ & 0.376 & $\mathrm{~J}$ & & HCJ-164-08 \\
\hline Tetrachloroethylene & E04808003013A & Pump Pit & $\# 16$ & 0.407 & $\mathrm{~J}$ & & HCJ-164-08 \\
\hline Tetrachloroethylene & E04808004013A & Pump Pit & $\# 18$ & 1.06 & $\mathrm{U}$ & & HCJ-164-08 \\
\hline Tetrachloroethylene & E04808005013A & Pump Pit & $\# 23$ & 1.04 & $\mathrm{U}$ & & HCJ-164-08 \\
\hline Tetrachloroethylene & E04808006013A & Tank Vault & $\# 8$ & 1.1 & $\mathrm{U}$ & & HCJ-164-08 \\
\hline Tetrachloroethylene & E04808007013A & Tank Vault & $\# 9$ & 1.09 & $\mathrm{U}$ & & HCJ-164-08 \\
\hline Tetrachloroethylene & E04808008013A & Tank Vault & $\# 15$ & 1.07 & $\mathrm{U}$ & & HCJ-164-08 \\
\hline Tetrachloroethylene & E04808009013A & Tank Vault & \#24 & 1.1 & $\mathrm{U}$ & & HCJ-164-08 \\
\hline Tetrachloroethylene & E04808010013A & Tank Vault & \#32 & 1.07 & $\mathrm{U}$ & & HCJ-164-08 \\
\hline Toluene & E04808001013A & Pump Pit & \#3 & 1.06 & $\mathrm{U}$ & & HCJ-164-08 \\
\hline Toluene & E04808002013A & Pump Pit & $\# 12$ & 1.07 & $\mathrm{U}$ & & HCJ-164-08 \\
\hline Toluene & E04808003013A & Pump Pit & $\# 16$ & 1.1 & $\mathrm{U}$ & & HCJ-164-08 \\
\hline Toluene & E04808004013A & Pump Pit & $\# 18$ & 1.06 & $\mathrm{U}$ & & HCJ-164-08 \\
\hline Toluene & E04808005013A & Pump Pit & $\# 23$ & 1.04 & $\mathrm{U}$ & & HCJ-164-08 \\
\hline Toluene & E04808006013A & Tank Vault & $\# 8$ & 0.333 & $\mathrm{~J}$ & & HCJ-164-08 \\
\hline Toluene & E04808007013A & Tank Vault & $\# 9$ & 1.09 & $\mathrm{U}$ & & HCJ-164-08 \\
\hline Toluene & E04808008013A & Tank Vault & $\# 15$ & 1.07 & $\mathrm{U}$ & & HCJ-164-08 \\
\hline Toluene & E04808009013A & Tank Vault & $\# 24$ & 1.1 & $\mathrm{U}$ & & HCJ-164-08 \\
\hline Toluene & E04808010013A & Tank Vault & \#32 & 1.07 & $\mathrm{U}$ & & HCJ-164-08 \\
\hline trans-1,2-Dichloroethene & E04808001013A & Pump Pit & \#3 & 1.06 & $\mathrm{U}$ & & HCJ-164-08 \\
\hline trans-1,2-Dichloroethene & E04808002013A & Pump Pit & \#12 & 1.07 & $\mathrm{U}$ & & HCJ-164-08 \\
\hline trans-1,2-Dichloroethene & E04808003013A & Pump Pit & $\# 16$ & 1.1 & $\mathrm{U}$ & & HCJ-164-08 \\
\hline trans-1,2-Dichloroethene & E04808004013A & Pump Pit & $\# 18$ & 1.06 & $\mathrm{U}$ & & HCJ-164-08 \\
\hline trans-1,2-Dichloroethene & E04808005013A & Pump Pit & $\# 23$ & 1.04 & $\mathrm{U}$ & & HCJ-164-08 \\
\hline trans-1,2-Dichloroethene & E04808006013A & Tank Vault & $\# 8$ & 1.1 & $\mathrm{U}$ & & HCJ-164-08 \\
\hline trans-1,2-Dichloroethene & E04808007013A & Tank Vault & $\# 9$ & 1.09 & $\mathrm{U}$ & & HCJ-164-08 \\
\hline trans-1,2-Dichloroethene & E04808008013A & Tank Vault & \#15 & 1.07 & $\mathrm{U}$ & & HCJ-164-08 \\
\hline trans-1,2-Dichloroethene & E04808009013A & Tank Vault & \#24 & 1.1 & $\mathrm{U}$ & & HCJ-164-08 \\
\hline trans-1,2-Dichloroethene & E04808010013A & Tank Vault & \#32 & 1.07 & $\mathrm{U}$ & & HCJ-164-08 \\
\hline trans-1,3-Dichloropropylene & E04808001013A & Pump Pit & \#3 & 1.06 & $\mathrm{U}$ & & HCJ-164-08 \\
\hline trans-1,3-Dichloropropylene & E04808002013A & Pump Pit & $\# 12$ & 1.07 & $\mathrm{U}$ & & HCJ-164-08 \\
\hline trans-1,3-Dichloropropylene & E04808003013A & Pump Pit & \#16 & 1.1 & $\mathrm{U}$ & & HCJ-164-08 \\
\hline trans-1,3-Dichloropropylene & E04808004013A & Pump Pit & $\# 18$ & 1.06 & $\mathrm{U}$ & & HCJ-164-08 \\
\hline trans-1,3-Dichloropropylene & E04808005013A & Pump Pit & \#23 & 1.04 & $\mathrm{U}$ & & HCJ-164-08 \\
\hline trans-1,3-Dichloropropylene & E04808006013A & Tank Vault & $\# 8$ & 1.1 & $\mathrm{U}$ & & HCJ-164-08 \\
\hline trans-1,3-Dichloropropylene & E04808007013A & Tank Vault & $\# 9$ & 1.09 & $\mathrm{U}$ & & HCJ-164-08 \\
\hline trans-1,3-Dichloropropylene & E04808008013A & Tank Vault & \#15 & 1.07 & $\mathrm{U}$ & & HCJ-164-08 \\
\hline trans-1,3-Dichloropropylene & E04808009013A & Tank Vault & \#24 & 1.1 & $\mathrm{U}$ & & HCJ-164-08 \\
\hline trans-1,3-Dichloropropylene & E04808010013A & Tank Vault & \#32 & 1.07 & $\mathrm{U}$ & & HCJ-164-08 \\
\hline trans-1,4-Dichloro-2-butene & E04808001013A & Pump Pit & $\# 3$ & 5.3 & $\mathrm{U}$ & & HCJ-164-08 \\
\hline trans-1,4-Dichloro-2-butene & E04808002013A & Pump Pit & \#12 & 5.36 & $\mathrm{U}$ & & HCJ-164-08 \\
\hline trans-1,4-Dichloro-2-butene & E04808003013A & Pump Pit & $\# 16$ & 5.5 & $\mathrm{U}$ & & HCJ-164-08 \\
\hline trans-1,4-Dichloro-2-butene & E04808004013A & Pump Pit & $\# 18$ & 5.28 & $\mathrm{U}$ & & HCJ-164-08 \\
\hline trans-1,4-Dichloro-2-butene & E04808005013A & Pump Pit & $\# 23$ & 5.22 & $\mathrm{U}$ & & HCJ-164-08 \\
\hline trans-1,4-Dichloro-2-butene & E04808006013A & Tank Vault & $\# 8$ & 5.5 & $\mathrm{U}$ & & HCJ-164-08 \\
\hline
\end{tabular}


Table G-3. (continued).

\begin{tabular}{|c|c|c|c|c|c|c|c|}
\hline Compound & $\begin{array}{c}\text { Field Sample } \\
\text { Number }\end{array}$ & Location & Grid & $\begin{array}{c}\text { Sample } \\
\text { Result } \\
(\mu \mathrm{g} / \mathrm{kg})\end{array}$ & $\begin{array}{l}\text { Result } \\
\text { Qual. }\end{array}$ & $\begin{array}{l}\text { Val. } \\
\text { Flag }\end{array}$ & $\begin{array}{c}\text { L\&V Report } \\
\text { Number }\end{array}$ \\
\hline trans-1,4-Dichloro-2-butene & E04808007013A & Tank Vault & $\# 9$ & 5.44 & $\mathrm{U}$ & & HCJ-164-08 \\
\hline trans-1,4-Dichloro-2-butene & E04808008013A & Tank Vault & $\# 15$ & 5.34 & $\mathrm{U}$ & & HCJ-164-08 \\
\hline trans-1,4-Dichloro-2-butene & E04808009013A & Tank Vault & $\# 24$ & 5.5 & $\mathrm{U}$ & & HCJ-164-08 \\
\hline trans-1,4-Dichloro-2-butene & E04808010013A & Tank Vault & \#32 & 5.36 & $\mathrm{U}$ & & HCJ-164-08 \\
\hline Trichloroethylene & E04808001013A & Pump Pit & $\# 3$ & 1.06 & $\mathrm{U}$ & & HCJ-164-08 \\
\hline Trichloroethylene & E04808002013A & Pump Pit & $\# 12$ & 1.07 & $\mathrm{U}$ & & HCJ-164-08 \\
\hline Trichloroethylene & E04808003013A & Pump Pit & $\# 16$ & 1.1 & $\mathrm{U}$ & & HCJ-164-08 \\
\hline Trichloroethylene & E04808004013A & Pump Pit & $\# 18$ & 1.06 & $\mathrm{U}$ & & HCJ-164-08 \\
\hline Trichloroethylene & E04808005013A & Pump Pit & $\# 23$ & 1.04 & $\mathrm{U}$ & & HCJ-164-08 \\
\hline Trichloroethylene & E04808006013A & Tank Vault & $\# 8$ & 1.1 & $\mathrm{U}$ & & HCJ-164-08 \\
\hline Trichloroethylene & E04808007013A & Tank Vault & $\# 9$ & 1.09 & $\mathrm{U}$ & & HCJ-164-08 \\
\hline Trichloroethylene & E04808008013A & Tank Vault & $\# 15$ & 1.07 & $\mathrm{U}$ & & HCJ-164-08 \\
\hline Trichloroethylene & E04808009013A & Tank Vault & $\# 24$ & 1.1 & $\mathrm{U}$ & & HCJ-164-08 \\
\hline Trichloroethylene & E04808010013A & Tank Vault & $\# 32$ & 1.07 & $\mathrm{U}$ & & HCJ-164-08 \\
\hline Trichlorofluoromethane & E04808001013A & Pump Pit & $\# 3$ & 1.06 & $\mathrm{U}$ & & HCJ-164-08 \\
\hline Trichlorofluoromethane & E04808002013A & Pump Pit & $\# 12$ & 1.07 & $\mathrm{U}$ & & HCJ-164-08 \\
\hline Trichlorofluoromethane & E04808003013A & Pump Pit & $\# 16$ & 1.1 & $\mathrm{U}$ & & HCJ-164-08 \\
\hline Trichlorofluoromethane & E04808004013A & Pump Pit & $\# 18$ & 1.06 & $\mathrm{U}$ & & HCJ-164-08 \\
\hline Trichlorofluoromethane & E04808005013A & Pump Pit & $\# 23$ & 1.04 & $\mathrm{U}$ & & HCJ-164-08 \\
\hline Trichlorofluoromethane & E04808006013A & Tank Vault & $\# 8$ & 1.1 & $\mathrm{U}$ & & HCJ-164-08 \\
\hline Trichlorofluoromethane & E04808007013A & Tank Vault & $\# 9$ & 1.09 & $\mathrm{U}$ & & HCJ-164-08 \\
\hline Trichlorofluoromethane & E04808008013A & Tank Vault & $\# 15$ & 1.07 & $\mathrm{U}$ & & HCJ-164-08 \\
\hline Trichlorofluoromethane & E04808009013A & Tank Vault & $\# 24$ & 1.1 & $\mathrm{U}$ & & HCJ-164-08 \\
\hline Trichlorofluoromethane & E04808010013A & Tank Vault & \#32 & 1.07 & $\mathrm{U}$ & & HCJ-164-08 \\
\hline Vinyl Acetate & E04808001013A & Pump Pit & $\# 3$ & 5.3 & $\mathrm{U}$ & & HCJ-164-08 \\
\hline Vinyl Acetate & E04808002013A & Pump Pit & $\# 12$ & 5.36 & $\mathrm{U}$ & & HCJ-164-08 \\
\hline Vinyl Acetate & E04808003013A & Pump Pit & $\# 16$ & 5.5 & $\mathrm{U}$ & & HCJ-164-08 \\
\hline Vinyl Acetate & E04808004013A & Pump Pit & $\# 18$ & 5.28 & $\mathrm{U}$ & & HCJ-164-08 \\
\hline Vinyl Acetate & E04808005013A & Pump Pit & $\# 23$ & 5.22 & $\mathrm{U}$ & & HCJ-164-08 \\
\hline Vinyl Acetate & E04808006013A & Tank Vault & $\# 8$ & 5.5 & $\mathrm{U}$ & & HCJ-164-08 \\
\hline Vinyl Acetate & E04808007013A & Tank Vault & $\# 9$ & 5.44 & $\mathrm{U}$ & & HCJ-164-08 \\
\hline Vinyl Acetate & E04808008013A & Tank Vault & $\# 15$ & 5.34 & $\mathrm{U}$ & & HCJ-164-08 \\
\hline Vinyl Acetate & E04808009013A & Tank Vault & $\# 24$ & 5.5 & $\mathrm{U}$ & & HCJ-164-08 \\
\hline Vinyl Acetate & E04808010013A & Tank Vault & \#32 & 5.36 & $\mathrm{U}$ & & HCJ-164-08 \\
\hline Vinyl Chloride & E04808001013A & Pump Pit & $\# 3$ & 1.06 & $\mathrm{U}$ & & HCJ-164-08 \\
\hline Vinyl Chloride & E04808002013A & Pump Pit & $\# 12$ & 1.07 & $\mathrm{U}$ & & HCJ-164-08 \\
\hline Vinyl Chloride & E04808003013A & Pump Pit & $\# 16$ & 1.1 & $\mathrm{U}$ & & HCJ-164-08 \\
\hline Vinyl Chloride & E04808004013A & Pump Pit & $\# 18$ & 1.06 & $\mathrm{U}$ & & HCJ-164-08 \\
\hline Vinyl Chloride & E04808005013A & Pump Pit & $\# 23$ & 1.04 & $\mathrm{U}$ & & HCJ-164-08 \\
\hline Vinyl Chloride & E04808006013A & Tank Vault & $\# 8$ & 1.1 & $\mathrm{U}$ & & HCJ-164-08 \\
\hline Vinyl Chloride & E04808007013A & Tank Vault & $\# 9$ & 1.09 & $\mathrm{U}$ & & HCJ-164-08 \\
\hline Vinyl Chloride & E04808008013A & Tank Vault & $\# 15$ & 1.07 & $\mathrm{U}$ & & HCJ-164-08 \\
\hline Vinyl Chloride & E04808009013A & Tank Vault & $\# 24$ & 1.1 & $\mathrm{U}$ & & HCJ-164-08 \\
\hline Vinyl Chloride & E04808010013A & Tank Vault & \#32 & 1.07 & $\mathrm{U}$ & & HCJ-164-08 \\
\hline Xylene (Total) & E04808001013A & Pump Pit & $\# 3$ & 1.06 & $\mathrm{U}$ & & HCJ-164-08 \\
\hline Xylene (Total) & E04808002013A & Pump Pit & $\# 12$ & 1.07 & $\mathrm{U}$ & & HCJ-164-08 \\
\hline Xylene (Total) & E04808003013A & Pump Pit & $\# 16$ & 1.1 & $\mathrm{U}$ & & HCJ-164-08 \\
\hline Xylene (Total) & E04808004013A & Pump Pit & $\# 18$ & 1.06 & $\mathrm{U}$ & & HCJ-164-08 \\
\hline
\end{tabular}


Table G-3. (continued).

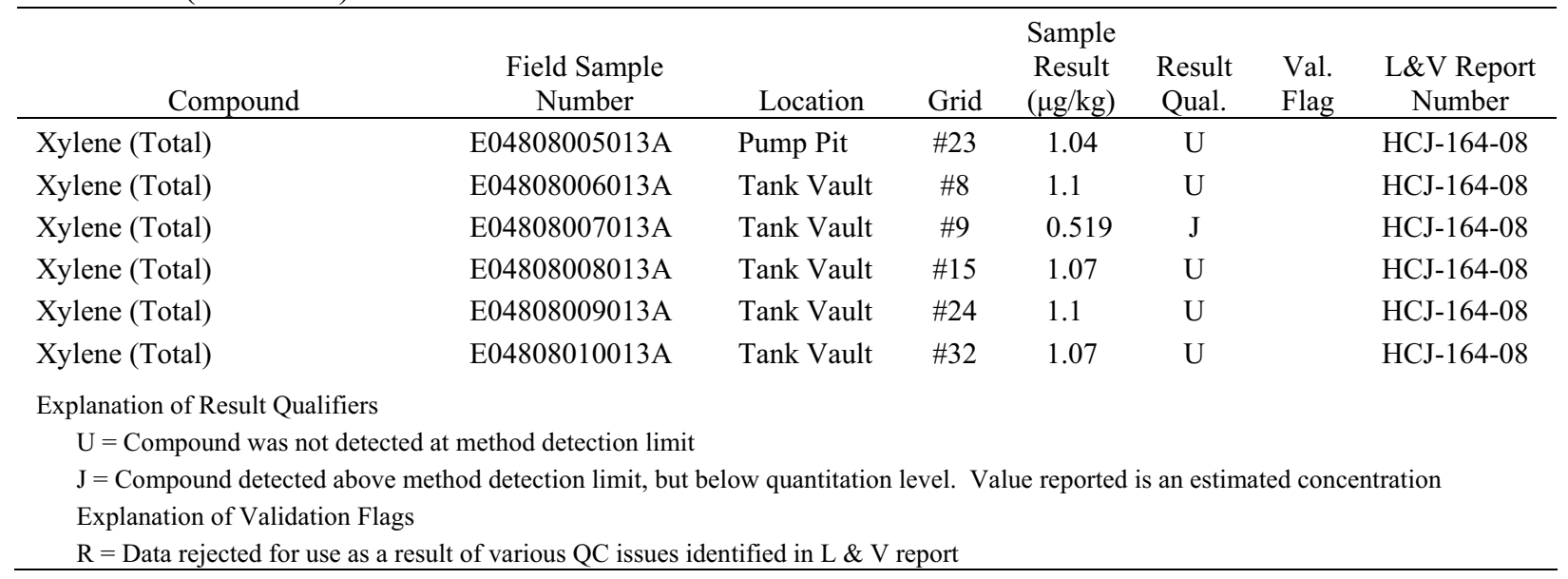


Table G-4. ESP-048-08 SFE-20 soil sample results for semi-volatile organic compounds.

\begin{tabular}{|c|c|c|c|c|c|c|c|}
\hline Compound & $\begin{array}{c}\text { Field Sample } \\
\text { Number }\end{array}$ & Location & Grid & $\begin{array}{c}\text { Sample } \\
\text { Result } \\
(\mu \mathrm{g} / \mathrm{kg})\end{array}$ & $\begin{array}{l}\text { Result } \\
\text { Qual. }\end{array}$ & $\begin{array}{l}\text { Val. } \\
\text { Flag }\end{array}$ & $\begin{array}{c}\text { L\&V Report } \\
\text { Number }\end{array}$ \\
\hline 1,2,4,5-Tetrachlorobenzene & E04808001013A & Pump Pit & $\# 3$ & 353 & U & & HCJ-006-09 \\
\hline $1,2,4,5$-Tetrachlorobenzene & E04808002013A & Pump Pit & $\# 12$ & 357 & $\mathrm{U}$ & & HCJ-006-09 \\
\hline $1,2,4,5$-Tetrachlorobenzene & E04808003013A & Pump Pit & $\# 16$ & 366 & $\mathrm{U}$ & & HCJ-006-09 \\
\hline 1,2,4,5-Tetrachlorobenzene & E04808004013A & Pump Pit & $\# 18$ & 352 & $\mathrm{U}$ & & HCJ-006-09 \\
\hline $1,2,4,5$-Tetrachlorobenzene & E04808005013A & Pump Pit & $\# 23$ & 348 & $\mathrm{U}$ & & HCJ-006-09 \\
\hline $1,2,4,5$-Tetrachlorobenzene & E04808006013A & Tank Vault & $\# 8$ & 366 & $\mathrm{U}$ & & HCJ-006-09 \\
\hline $1,2,4,5$-Tetrachlorobenzene & E04808007013A & Tank Vault & $\# 9$ & 362 & $\mathrm{U}$ & & HCJ-006-09 \\
\hline 1,2,4,5-Tetrachlorobenzene & E04808008013A & Tank Vault & $\# 15$ & 355 & $\mathrm{U}$ & & HCJ-006-09 \\
\hline $1,2,4,5$-Tetrachlorobenzene & E04808009013A & Tank Vault & \#24 & 367 & $\mathrm{U}$ & & HCJ-006-09 \\
\hline $1,2,4,5$-Tetrachlorobenzene & E04808010013A & Tank Vault & \#32 & 357 & $\mathrm{U}$ & & HCJ-006-09 \\
\hline 1,2,4-Trichlorobenzene & E04808001013A & Pump Pit & $\# 3$ & 353 & $\mathrm{U}$ & & HCJ-006-09 \\
\hline 1,2,4-Trichlorobenzene & E04808002013A & Pump Pit & $\# 12$ & 357 & $\mathrm{U}$ & & HCJ-006-09 \\
\hline 1,2,4-Trichlorobenzene & E04808003013A & Pump Pit & $\# 16$ & 366 & $\mathrm{U}$ & & HCJ-006-09 \\
\hline 1,2,4-Trichlorobenzene & E04808004013A & Pump Pit & $\# 18$ & 352 & $\mathrm{U}$ & & HCJ-006-09 \\
\hline 1,2,4-Trichlorobenzene & E04808005013A & Pump Pit & $\# 23$ & 348 & $\mathrm{U}$ & & HCJ-006-09 \\
\hline 1,2,4-Trichlorobenzene & E04808006013A & Tank Vault & $\# 8$ & 366 & $\mathrm{U}$ & & HCJ-006-09 \\
\hline 1,2,4-Trichlorobenzene & E04808007013A & Tank Vault & $\# 9$ & 362 & $\mathrm{U}$ & & HCJ-006-09 \\
\hline 1,2,4-Trichlorobenzene & E04808008013A & Tank Vault & $\# 15$ & 355 & $\mathrm{U}$ & & HCJ-006-09 \\
\hline 1,2,4-Trichlorobenzene & E04808009013A & Tank Vault & $\# 24$ & 367 & $\mathrm{U}$ & & HCJ-006-09 \\
\hline 1,2,4-Trichlorobenzene & E04808010013A & Tank Vault & $\# 32$ & 357 & $\mathrm{U}$ & & HCJ-006-09 \\
\hline 1,2-Dichlorobenzene & E04808001013A & Pump Pit & $\# 3$ & 353 & $\mathrm{U}$ & & HCJ-006-09 \\
\hline 1,2-Dichlorobenzene & E04808002013A & Pump Pit & $\# 12$ & 357 & $\mathrm{U}$ & & HCJ-006-09 \\
\hline 1,2-Dichlorobenzene & E04808003013A & Pump Pit & $\# 16$ & 366 & $\mathrm{U}$ & & HCJ-006-09 \\
\hline 1,2-Dichlorobenzene & E04808004013A & Pump Pit & $\# 18$ & 352 & $\mathrm{U}$ & & HCJ-006-09 \\
\hline 1,2-Dichlorobenzene & E04808005013A & Pump Pit & $\# 23$ & 348 & $\mathrm{U}$ & & HCJ-006-09 \\
\hline 1,2-Dichlorobenzene & E04808006013A & Tank Vault & $\# 8$ & 366 & $\mathrm{U}$ & & HCJ-006-09 \\
\hline 1,2-Dichlorobenzene & E04808007013A & Tank Vault & $\# 9$ & 362 & $\mathrm{U}$ & & HCJ-006-09 \\
\hline 1,2-Dichlorobenzene & E04808008013A & Tank Vault & $\# 15$ & 355 & $\mathrm{U}$ & & HCJ-006-09 \\
\hline 1,2-Dichlorobenzene & E04808009013A & Tank Vault & $\# 24$ & 367 & $\mathrm{U}$ & & HCJ-006-09 \\
\hline 1,2-Dichlorobenzene & E04808010013A & Tank Vault & \#32 & 357 & $\mathrm{U}$ & & HCJ-006-09 \\
\hline 1,3,5-Trinitrobenzene & E04808001013A & Pump Pit & $\# 3$ & 353 & $\mathrm{U}$ & & HCJ-006-09 \\
\hline 1,3,5-Trinitrobenzene & E04808002013A & Pump Pit & $\# 12$ & 357 & $\mathrm{U}$ & & HCJ-006-09 \\
\hline 1,3,5-Trinitrobenzene & E04808003013A & Pump Pit & $\# 16$ & 366 & $\mathrm{U}$ & & HCJ-006-09 \\
\hline 1,3,5-Trinitrobenzene & E04808004013A & Pump Pit & $\# 18$ & 352 & $\mathrm{U}$ & & HCJ-006-09 \\
\hline 1,3,5-Trinitrobenzene & E04808005013A & Pump Pit & $\# 23$ & 348 & $\mathrm{U}$ & & HCJ-006-09 \\
\hline 1,3,5-Trinitrobenzene & E04808006013A & Tank Vault & $\# 8$ & 366 & $\mathrm{U}$ & & HCJ-006-09 \\
\hline 1,3,5-Trinitrobenzene & E04808007013A & Tank Vault & $\# 9$ & 362 & $\mathrm{U}$ & & HCJ-006-09 \\
\hline 1,3,5-Trinitrobenzene & E04808008013A & Tank Vault & $\# 15$ & 355 & $\mathrm{U}$ & & HCJ-006-09 \\
\hline 1,3,5-Trinitrobenzene & E04808009013A & Tank Vault & $\# 24$ & 367 & $\mathrm{U}$ & & HCJ-006-09 \\
\hline 1,3,5-Trinitrobenzene & E04808010013A & Tank Vault & $\# 32$ & 357 & $\mathrm{U}$ & & HCJ-006-09 \\
\hline 1,3-Dichlorobenzene & E04808001013A & Pump Pit & $\# 3$ & 353 & $\mathrm{U}$ & & HCJ-006-09 \\
\hline 1,3-Dichlorobenzene & E04808002013A & Pump Pit & $\# 12$ & 357 & $\mathrm{U}$ & & HCJ-006-09 \\
\hline 1,3-Dichlorobenzene & E04808003013A & Pump Pit & $\# 16$ & 366 & $\mathrm{U}$ & & HCJ-006-09 \\
\hline 1,3-Dichlorobenzene & E04808004013A & Pump Pit & $\# 18$ & 352 & $\mathrm{U}$ & & HCJ-006-09 \\
\hline 1,3-Dichlorobenzene & E04808005013A & Pump Pit & $\# 23$ & 348 & $\mathrm{U}$ & & HCJ-006-09 \\
\hline 1,3-Dichlorobenzene & E04808006013A & Tank Vault & $\# 8$ & 366 & $\mathrm{U}$ & & HCJ-006-09 \\
\hline 1,3-Dichlorobenzene & E04808007013A & Tank Vault & $\# 9$ & 362 & $\mathrm{U}$ & & HCJ-006-09 \\
\hline 1,3-Dichlorobenzene & E04808008013A & Tank Vault & $\# 15$ & 355 & $\mathrm{U}$ & & HCJ-006-09 \\
\hline
\end{tabular}


Table G-4. (continued).

\begin{tabular}{|c|c|c|c|c|c|c|c|}
\hline Compound & $\begin{array}{l}\text { Field Sample } \\
\text { Number }\end{array}$ & Location & Grid & $\begin{array}{l}\text { Sample } \\
\text { Result } \\
(\mu \mathrm{g} / \mathrm{kg})\end{array}$ & $\begin{array}{l}\text { Result } \\
\text { Qual. }\end{array}$ & $\begin{array}{l}\text { Val. } \\
\text { Flag }\end{array}$ & $\begin{array}{l}\text { L\&V Report } \\
\text { Number }\end{array}$ \\
\hline 1,3-Dichlorobenzene & E04808009013A & Tank Vault & $\# 24$ & 367 & $\mathrm{U}$ & & HCJ-006-09 \\
\hline 1,3-Dichlorobenzene & E04808010013A & Tank Vault & \#32 & 357 & $\mathrm{U}$ & & HCJ-006-09 \\
\hline 1,4-Dichlorobenzene & E04808001013A & Pump Pit & $\# 3$ & 353 & $\mathrm{U}$ & & HCJ-006-09 \\
\hline 1,4-Dichlorobenzene & E04808002013A & Pump Pit & $\# 12$ & 357 & $\mathrm{U}$ & & HCJ-006-09 \\
\hline 1,4-Dichlorobenzene & E04808003013A & Pump Pit & $\# 16$ & 366 & $\mathrm{U}$ & & HCJ-006-09 \\
\hline 1,4-Dichlorobenzene & E04808004013A & Pump Pit & $\# 18$ & 352 & $\mathrm{U}$ & & HCJ-006-09 \\
\hline 1,4-Dichlorobenzene & E04808005013A & Pump Pit & \#23 & 348 & $\mathrm{U}$ & & HCJ-006-09 \\
\hline 1,4-Dichlorobenzene & E04808006013A & Tank Vault & $\# 8$ & 366 & $\mathrm{U}$ & & HCJ-006-09 \\
\hline 1,4-Dichlorobenzene & E04808007013A & Tank Vault & $\# 9$ & 362 & $\mathrm{U}$ & & HCJ-006-09 \\
\hline 1,4-Dichlorobenzene & E04808008013A & Tank Vault & $\# 15$ & 355 & $\mathrm{U}$ & & HCJ-006-09 \\
\hline 1,4-Dichlorobenzene & E04808009013A & Tank Vault & \#24 & 367 & $\mathrm{U}$ & & HCJ-006-09 \\
\hline 1,4-Dichlorobenzene & E04808010013A & Tank Vault & \#32 & 357 & $\mathrm{U}$ & & HCJ-006-09 \\
\hline 1,4-Naphthoquinone & E04808001013A & Pump Pit & $\# 3$ & 353 & $\mathrm{U}$ & & HCJ-006-09 \\
\hline 1,4-Naphthoquinone & E04808002013A & Pump Pit & $\# 12$ & 357 & $\mathrm{U}$ & & HCJ-006-09 \\
\hline 1,4-Naphthoquinone & E04808003013A & Pump Pit & $\# 16$ & 366 & $\mathrm{U}$ & & HCJ-006-09 \\
\hline 1,4-Naphthoquinone & E04808004013A & Pump Pit & $\# 18$ & 352 & $\mathrm{U}$ & & HCJ-006-09 \\
\hline 1,4-Naphthoquinone & E04808005013A & Pump Pit & \#23 & 348 & $\mathrm{U}$ & & HCJ-006-09 \\
\hline 1,4-Naphthoquinone & E04808006013A & Tank Vault & $\# 8$ & 366 & $\mathrm{U}$ & & HCJ-006-09 \\
\hline 1,4-Naphthoquinone & E04808007013A & Tank Vault & $\# 9$ & 362 & $\mathrm{U}$ & & HCJ-006-09 \\
\hline 1,4-Naphthoquinone & E04808008013A & Tank Vault & $\# 15$ & 355 & $\mathrm{U}$ & & HCJ-006-09 \\
\hline 1,4-Naphthoquinone & E04808009013A & Tank Vault & \#24 & 367 & $\mathrm{U}$ & & HCJ-006-09 \\
\hline 1,4-Naphthoquinone & E04808010013A & Tank Vault & \#32 & 357 & $\mathrm{U}$ & & HCJ-006-09 \\
\hline 1-Naphthylamine & E04808001013A & Pump Pit & $\# 3$ & 353 & $\mathrm{U}$ & & HCJ-006-09 \\
\hline 1-Naphthylamine & E04808002013A & Pump Pit & $\# 12$ & 357 & $\mathrm{U}$ & & HCJ-006-09 \\
\hline 1-Naphthylamine & E04808003013A & Pump Pit & $\# 16$ & 366 & $\mathrm{U}$ & & HCJ-006-09 \\
\hline 1-Naphthylamine & E04808004013A & Pump Pit & $\# 18$ & 352 & $\mathrm{U}$ & & HCJ-006-09 \\
\hline 1-Naphthylamine & E04808005013A & Pump Pit & \#23 & 348 & $\mathrm{U}$ & & HCJ-006-09 \\
\hline 1-Naphthylamine & E04808006013A & Tank Vault & $\# 8$ & 366 & $\mathrm{U}$ & & HCJ-006-09 \\
\hline 1-Naphthylamine & E04808007013A & Tank Vault & $\# 9$ & 362 & $\mathrm{U}$ & & HCJ-006-09 \\
\hline 1-Naphthylamine & E04808008013A & Tank Vault & $\# 15$ & 355 & $\mathrm{U}$ & & HCJ-006-09 \\
\hline 1-Naphthylamine & E04808009013A & Tank Vault & \#24 & 367 & $\mathrm{U}$ & & HCJ-006-09 \\
\hline 1-Naphthylamine & E04808010013A & Tank Vault & \#32 & 357 & $\mathrm{U}$ & & HCJ-006-09 \\
\hline 2,3,4,6-Tetrachlorophenol & E04808001013A & Pump Pit & $\# 3$ & 353 & $\mathrm{U}$ & & HCJ-006-09 \\
\hline 2,3,4,6-Tetrachlorophenol & E04808002013A & Pump Pit & $\# 12$ & 357 & $\mathrm{U}$ & & HCJ-006-09 \\
\hline 2,3,4,6-Tetrachlorophenol & E04808003013A & Pump Pit & $\# 16$ & 366 & $\mathrm{U}$ & & HCJ-006-09 \\
\hline 2,3,4,6-Tetrachlorophenol & E04808004013A & Pump Pit & $\# 18$ & 352 & $\mathrm{U}$ & & HCJ-006-09 \\
\hline 2,3,4,6-Tetrachlorophenol & E04808005013A & Pump Pit & \#23 & 348 & $\mathrm{U}$ & & HCJ-006-09 \\
\hline 2,3,4,6-Tetrachlorophenol & E04808006013A & Tank Vault & $\# 8$ & 366 & $\mathrm{U}$ & & HCJ-006-09 \\
\hline 2,3,4,6-Tetrachlorophenol & E04808007013A & Tank Vault & $\# 9$ & 362 & $\mathrm{U}$ & & HCJ-006-09 \\
\hline 2,3,4,6-Tetrachlorophenol & E04808008013A & Tank Vault & $\# 15$ & 355 & $\mathrm{U}$ & & HCJ-006-09 \\
\hline 2,3,4,6-Tetrachlorophenol & E04808009013A & Tank Vault & $\# 24$ & 367 & $\mathrm{U}$ & & HCJ-006-09 \\
\hline 2,3,4,6-Tetrachlorophenol & E04808010013A & Tank Vault & \#32 & 357 & $\mathrm{U}$ & & HCJ-006-09 \\
\hline 2,4,5-Trichlorophenol & E04808001013A & Pump Pit & $\# 3$ & 353 & $\mathrm{U}$ & & HCJ-006-09 \\
\hline 2,4,5-Trichlorophenol & E04808002013A & Pump Pit & $\# 12$ & 357 & $\mathrm{U}$ & & HCJ-006-09 \\
\hline 2,4,5-Trichlorophenol & E04808003013A & Pump Pit & $\# 16$ & 366 & $\mathrm{U}$ & & HCJ-006-09 \\
\hline 2,4,5-Trichlorophenol & E04808004013A & Pump Pit & $\# 18$ & 352 & $\mathrm{U}$ & & HCJ-006-09 \\
\hline 2,4,5-Trichlorophenol & E04808005013A & Pump Pit & \#23 & 348 & $\mathrm{U}$ & & HCJ-006-09 \\
\hline 2,4,5-Trichlorophenol & E04808006013A & Tank Vault & $\# 8$ & 366 & $\mathrm{U}$ & & HCJ-006-09 \\
\hline 2,4,5-Trichlorophenol & E04808007013A & Tank Vault & $\# 9$ & 362 & $\mathrm{U}$ & & HCJ-006-09 \\
\hline
\end{tabular}


Table G-4. (continued).

\begin{tabular}{|c|c|c|c|c|c|c|c|}
\hline Compound & $\begin{array}{c}\text { Field Sample } \\
\text { Number }\end{array}$ & Location & Grid & $\begin{array}{c}\text { Sample } \\
\text { Result } \\
(\mu \mathrm{g} / \mathrm{kg})\end{array}$ & $\begin{array}{l}\text { Result } \\
\text { Qual. }\end{array}$ & $\begin{array}{l}\text { Val. } \\
\text { Flag }\end{array}$ & $\begin{array}{c}\text { L\&V Report } \\
\text { Number }\end{array}$ \\
\hline 2,4,5-Trichlorophenol & E04808008013A & Tank Vault & $\# 15$ & 355 & $\mathrm{U}$ & & HCJ-006-09 \\
\hline 2,4,5-Trichlorophenol & E04808009013A & Tank Vault & \#24 & 367 & $\mathrm{U}$ & & HCJ-006-09 \\
\hline 2,4,5-Trichlorophenol & E04808010013A & Tank Vault & \#32 & 357 & $\mathrm{U}$ & & HCJ-006-09 \\
\hline 2,4,6-Trichlorophenol & E04808001013A & Pump Pit & \#3 & 353 & $\mathrm{U}$ & & HCJ-006-09 \\
\hline 2,4,6-Trichlorophenol & E04808002013A & Pump Pit & $\# 12$ & 357 & $\mathrm{U}$ & & HCJ-006-09 \\
\hline 2,4,6-Trichlorophenol & E04808003013A & Pump Pit & $\# 16$ & 366 & $\mathrm{U}$ & & HCJ-006-09 \\
\hline 2,4,6-Trichlorophenol & E04808004013A & Pump Pit & \#18 & 352 & $\mathrm{U}$ & & HCJ-006-09 \\
\hline 2,4,6-Trichlorophenol & E04808005013A & Pump Pit & \#23 & 348 & $\mathrm{U}$ & & HCJ-006-09 \\
\hline 2,4,6-Trichlorophenol & E04808006013A & Tank Vault & $\# 8$ & 366 & $\mathrm{U}$ & & HCJ-006-09 \\
\hline 2,4,6-Trichlorophenol & E04808007013A & Tank Vault & $\# 9$ & 362 & $\mathrm{U}$ & & HCJ-006-09 \\
\hline 2,4,6-Trichlorophenol & E04808008013A & Tank Vault & $\# 15$ & 355 & $\mathrm{U}$ & & HCJ-006-09 \\
\hline 2,4,6-Trichlorophenol & E04808009013A & Tank Vault & \#24 & 367 & $\mathrm{U}$ & & HCJ-006-09 \\
\hline 2,4,6-Trichlorophenol & E04808010013A & Tank Vault & \#32 & 357 & $\mathrm{U}$ & & HCJ-006-09 \\
\hline 2,4-Dichlorophenol & E04808001013A & Pump Pit & $\# 3$ & 353 & $\mathrm{U}$ & & HCJ-006-09 \\
\hline 2,4-Dichlorophenol & E04808002013A & Pump Pit & \#12 & 357 & $\mathrm{U}$ & & HCJ-006-09 \\
\hline 2,4-Dichlorophenol & E04808003013A & Pump Pit & $\# 16$ & 366 & $\mathrm{U}$ & & HCJ-006-09 \\
\hline 2,4-Dichlorophenol & E04808004013A & Pump Pit & $\# 18$ & 352 & $\mathrm{U}$ & & HCJ-006-09 \\
\hline 2,4-Dichlorophenol & E04808005013A & Pump Pit & \#23 & 348 & $\mathrm{U}$ & & HCJ-006-09 \\
\hline 2,4-Dichlorophenol & E04808006013A & Tank Vault & $\# 8$ & 366 & $\mathrm{U}$ & & HCJ-006-09 \\
\hline 2,4-Dichlorophenol & E04808007013A & Tank Vault & $\# 9$ & 362 & $\mathrm{U}$ & & HCJ-006-09 \\
\hline 2,4-Dichlorophenol & E04808008013A & Tank Vault & $\# 15$ & 355 & $\mathrm{U}$ & & HCJ-006-09 \\
\hline 2,4-Dichlorophenol & E04808009013A & Tank Vault & \#24 & 367 & $\mathrm{U}$ & & HCJ-006-09 \\
\hline 2,4-Dichlorophenol & E04808010013A & Tank Vault & \#32 & 357 & $\mathrm{U}$ & & HCJ-006-09 \\
\hline 2,4-Dimethylphenol & E04808001013A & Pump Pit & \#3 & 353 & $\mathrm{U}$ & & HCJ-006-09 \\
\hline 2,4-Dimethylphenol & E04808002013A & Pump Pit & $\# 12$ & 357 & $\mathrm{U}$ & & HCJ-006-09 \\
\hline 2,4-Dimethylphenol & E04808003013A & Pump Pit & $\# 16$ & 366 & $\mathrm{U}$ & & HCJ-006-09 \\
\hline 2,4-Dimethylphenol & E04808004013A & Pump Pit & \#18 & 352 & $\mathrm{U}$ & & HCJ-006-09 \\
\hline 2,4-Dimethylphenol & E04808005013A & Pump Pit & \#23 & 348 & $\mathrm{U}$ & & HCJ-006-09 \\
\hline 2,4-Dimethylphenol & E04808006013A & Tank Vault & $\# 8$ & 366 & $\mathrm{U}$ & & HCJ-006-09 \\
\hline 2,4-Dimethylphenol & E04808007013A & Tank Vault & $\# 9$ & 362 & $\mathrm{U}$ & & HCJ-006-09 \\
\hline 2,4-Dimethylphenol & E04808008013A & Tank Vault & $\# 15$ & 355 & $\mathrm{U}$ & & HCJ-006-09 \\
\hline 2,4-Dimethylphenol & E04808009013A & Tank Vault & $\# 24$ & 367 & $\mathrm{U}$ & & HCJ-006-09 \\
\hline 2,4-Dimethylphenol & E04808010013A & Tank Vault & \#32 & 357 & $\mathrm{U}$ & & HCJ-006-09 \\
\hline 2,4-Dinitrophenol & E04808001013A & Pump Pit & $\# 3$ & 706 & $\mathrm{U}$ & & HCJ-006-09 \\
\hline 2,4-Dinitrophenol & E04808002013A & Pump Pit & $\# 12$ & 715 & $\mathrm{U}$ & & HCJ-006-09 \\
\hline 2,4-Dinitrophenol & E04808003013A & Pump Pit & $\# 16$ & 733 & $\mathrm{U}$ & & HCJ-006-09 \\
\hline 2,4-Dinitrophenol & E04808004013A & Pump Pit & $\# 18$ & 704 & $\mathrm{U}$ & & HCJ-006-09 \\
\hline 2,4-Dinitrophenol & E04808005013A & Pump Pit & \#23 & 695 & $\mathrm{U}$ & & HCJ-006-09 \\
\hline 2,4-Dinitrophenol & E04808006013A & Tank Vault & $\# 8$ & 732 & $\mathrm{U}$ & & HCJ-006-09 \\
\hline 2,4-Dinitrophenol & E04808007013A & Tank Vault & $\# 9$ & 724 & $\mathrm{U}$ & & HCJ-006-09 \\
\hline 2,4-Dinitrophenol & E04808008013A & Tank Vault & $\# 15$ & 711 & $\mathrm{U}$ & & HCJ-006-09 \\
\hline 2,4-Dinitrophenol & E04808009013A & Tank Vault & \#24 & 734 & $\mathrm{U}$ & & HCJ-006-09 \\
\hline 2,4-Dinitrophenol & E04808010013A & Tank Vault & \#32 & 713 & $\mathrm{U}$ & & HCJ-006-09 \\
\hline 2,4-Dinitrotoluene & E04808001013A & Pump Pit & $\# 3$ & 353 & $\mathrm{U}$ & & HCJ-006-09 \\
\hline 2,4-Dinitrotoluene & E04808002013A & Pump Pit & \#12 & 357 & $\mathrm{U}$ & & HCJ-006-09 \\
\hline 2,4-Dinitrotoluene & E04808003013A & Pump Pit & $\# 16$ & 366 & $\mathrm{U}$ & & HCJ-006-09 \\
\hline 2,4-Dinitrotoluene & E04808004013A & Pump Pit & $\# 18$ & 352 & $\mathrm{U}$ & & HCJ-006-09 \\
\hline 2,4-Dinitrotoluene & E04808005013A & Pump Pit & \#23 & 348 & $\mathrm{U}$ & & HCJ-006-09 \\
\hline 2,4-Dinitrotoluene & E04808006013A & Tank Vault & $\# 8$ & 366 & $\mathrm{U}$ & & HCJ-006-09 \\
\hline
\end{tabular}


Table G-4. (continued).

\begin{tabular}{|c|c|c|c|c|c|c|c|}
\hline Compound & $\begin{array}{c}\text { Field Sample } \\
\text { Number }\end{array}$ & Location & Grid & $\begin{array}{c}\text { Sample } \\
\text { Result } \\
(\mu \mathrm{g} / \mathrm{kg})\end{array}$ & $\begin{array}{l}\text { Result } \\
\text { Qual. }\end{array}$ & $\begin{array}{l}\text { Val. } \\
\text { Flag }\end{array}$ & $\begin{array}{c}\text { L\&V Report } \\
\text { Number }\end{array}$ \\
\hline 2,4-Dinitrotoluene & E04808007013A & Tank Vault & \#9 & 362 & $\mathrm{U}$ & & HCJ-006-09 \\
\hline 2,4-Dinitrotoluene & E04808008013A & Tank Vault & $\# 15$ & 355 & $\mathrm{U}$ & & HCJ-006-09 \\
\hline 2,4-Dinitrotoluene & E04808009013A & Tank Vault & $\# 24$ & 367 & $\mathrm{U}$ & & HCJ-006-09 \\
\hline 2,4-Dinitrotoluene & E04808010013A & Tank Vault & \#32 & 357 & $\mathrm{U}$ & & HCJ-006-09 \\
\hline 2,6-Dichlorophenol & E04808001013A & Pump Pit & $\# 3$ & 353 & $\mathrm{U}$ & & HCJ-006-09 \\
\hline 2,6-Dichlorophenol & E04808002013A & Pump Pit & $\# 12$ & 357 & $\mathrm{U}$ & & HCJ-006-09 \\
\hline 2,6-Dichlorophenol & E04808003013A & Pump Pit & $\# 16$ & 366 & $\mathrm{U}$ & & HCJ-006-09 \\
\hline 2,6-Dichlorophenol & E04808004013A & Pump Pit & $\# 18$ & 352 & $\mathrm{U}$ & & HCJ-006-09 \\
\hline 2,6-Dichlorophenol & E04808005013A & Pump Pit & \#23 & 348 & $\mathrm{U}$ & & HCJ-006-09 \\
\hline 2,6-Dichlorophenol & E04808006013A & Tank Vault & $\# 8$ & 366 & $\mathrm{U}$ & & HCJ-006-09 \\
\hline 2,6-Dichlorophenol & E04808007013A & Tank Vault & $\# 9$ & 362 & $\mathrm{U}$ & & HCJ-006-09 \\
\hline 2,6-Dichlorophenol & E04808008013A & Tank Vault & $\# 15$ & 355 & $\mathrm{U}$ & & HCJ-006-09 \\
\hline 2,6-Dichlorophenol & E04808009013A & Tank Vault & $\# 24$ & 367 & $\mathrm{U}$ & & HCJ-006-09 \\
\hline 2,6-Dichlorophenol & E04808010013A & Tank Vault & \#32 & 357 & $\mathrm{U}$ & & HCJ-006-09 \\
\hline 2,6-Dinitrotoluene & E04808001013A & Pump Pit & $\# 3$ & 353 & $\mathrm{U}$ & & HCJ-006-09 \\
\hline 2,6-Dinitrotoluene & E04808002013A & Pump Pit & $\# 12$ & 357 & $\mathrm{U}$ & & HCJ-006-09 \\
\hline 2,6-Dinitrotoluene & E04808003013A & Pump Pit & $\# 16$ & 366 & $\mathrm{U}$ & & HCJ-006-09 \\
\hline 2,6-Dinitrotoluene & E04808004013A & Pump Pit & $\# 18$ & 352 & $\mathrm{U}$ & & HCJ-006-09 \\
\hline 2,6-Dinitrotoluene & E04808005013A & Pump Pit & \#23 & 348 & $\mathrm{U}$ & & HCJ-006-09 \\
\hline 2,6-Dinitrotoluene & E04808006013A & Tank Vault & $\# 8$ & 366 & $\mathrm{U}$ & & HCJ-006-09 \\
\hline 2,6-Dinitrotoluene & E04808007013A & Tank Vault & $\# 9$ & 362 & $\mathrm{U}$ & & HCJ-006-09 \\
\hline 2,6-Dinitrotoluene & E04808008013A & Tank Vault & $\# 15$ & 355 & $\mathrm{U}$ & & HCJ-006-09 \\
\hline 2,6-Dinitrotoluene & E04808009013A & Tank Vault & $\# 24$ & 367 & $\mathrm{U}$ & & HCJ-006-09 \\
\hline 2,6-Dinitrotoluene & E04808010013A & Tank Vault & \#32 & 357 & $\mathrm{U}$ & & HCJ-006-09 \\
\hline 2-Acetylaminofluorene & E04808001013A & Pump Pit & $\# 3$ & 353 & $\mathrm{U}$ & & HCJ-006-09 \\
\hline 2-Acetylaminofluorene & E04808002013A & Pump Pit & $\# 12$ & 357 & $\mathrm{U}$ & & HCJ-006-09 \\
\hline 2-Acetylaminofluorene & E04808003013A & Pump Pit & $\# 16$ & 366 & $\mathrm{U}$ & & HCJ-006-09 \\
\hline 2-Acetylaminofluorene & E04808004013A & Pump Pit & $\# 18$ & 352 & $\mathrm{U}$ & & HCJ-006-09 \\
\hline 2-Acetylaminofluorene & E04808005013A & Pump Pit & \#23 & 348 & $\mathrm{U}$ & & HCJ-006-09 \\
\hline 2-Acetylaminofluorene & E04808006013A & Tank Vault & $\# 8$ & 366 & $\mathrm{U}$ & & HCJ-006-09 \\
\hline 2-Acetylaminofluorene & E04808007013A & Tank Vault & $\# 9$ & 362 & $\mathrm{U}$ & & HCJ-006-09 \\
\hline 2-Acetylaminofluorene & E04808008013A & Tank Vault & $\# 15$ & 355 & $\mathrm{U}$ & & HCJ-006-09 \\
\hline 2-Acetylaminofluorene & E04808009013A & Tank Vault & $\# 24$ & 367 & $\mathrm{U}$ & & HCJ-006-09 \\
\hline 2-Acetylaminofluorene & E04808010013A & Tank Vault & \#32 & 357 & $\mathrm{U}$ & & HCJ-006-09 \\
\hline 2-Chloronaphthalene & E04808001013A & Pump Pit & $\# 3$ & 35 & $\mathrm{U}$ & & HCJ-006-09 \\
\hline 2-Chloronaphthalene & E04808002013A & Pump Pit & $\# 12$ & 36 & $\mathrm{U}$ & & HCJ-006-09 \\
\hline 2-Chloronaphthalene & E04808003013A & Pump Pit & $\# 16$ & 37 & $\mathrm{U}$ & & HCJ-006-09 \\
\hline 2-Chloronaphthalene & E04808004013A & Pump Pit & \#18 & 35 & $\mathrm{U}$ & & HCJ-006-09 \\
\hline 2-Chloronaphthalene & E04808005013A & Pump Pit & \#23 & 35 & $\mathrm{U}$ & & HCJ-006-09 \\
\hline 2-Chloronaphthalene & E04808006013A & Tank Vault & $\# 8$ & 37 & $\mathrm{U}$ & & HCJ-006-09 \\
\hline 2-Chloronaphthalene & E04808007013A & Tank Vault & $\# 9$ & 36 & $\mathrm{U}$ & & HCJ-006-09 \\
\hline 2-Chloronaphthalene & E04808008013A & Tank Vault & $\# 15$ & 36 & $\mathrm{U}$ & & HCJ-006-09 \\
\hline 2-Chloronaphthalene & E04808009013A & Tank Vault & $\# 24$ & 37 & $\mathrm{U}$ & & HCJ-006-09 \\
\hline 2-Chloronaphthalene & E04808010013A & Tank Vault & \#32 & 36 & $\mathrm{U}$ & & HCJ-006-09 \\
\hline 2-Chlorophenol & E04808001013A & Pump Pit & $\# 3$ & 353 & $\mathrm{U}$ & & HCJ-006-09 \\
\hline 2-Chlorophenol & E04808002013A & Pump Pit & $\# 12$ & 357 & $\mathrm{U}$ & & HCJ-006-09 \\
\hline 2-Chlorophenol & E04808003013A & Pump Pit & $\# 16$ & 366 & $\mathrm{U}$ & & HCJ-006-09 \\
\hline 2-Chlorophenol & E04808004013A & Pump Pit & $\# 18$ & 352 & $\mathrm{U}$ & & HCJ-006-09 \\
\hline 2-Chlorophenol & E04808005013A & Pump Pit & \#23 & 348 & $\mathrm{U}$ & & HCJ-006-09 \\
\hline
\end{tabular}


Table G-4. (continued).

\begin{tabular}{|c|c|c|c|c|c|c|c|}
\hline Compound & $\begin{array}{l}\text { Field Sample } \\
\text { Number }\end{array}$ & Location & Grid & $\begin{array}{l}\text { Sample } \\
\text { Result } \\
(\mu \mathrm{g} / \mathrm{kg})\end{array}$ & $\begin{array}{l}\text { Result } \\
\text { Qual. }\end{array}$ & $\begin{array}{l}\text { Val. } \\
\text { Flag }\end{array}$ & $\begin{array}{l}\text { L\&V Report } \\
\text { Number }\end{array}$ \\
\hline 2-Chlorophenol & E04808006013A & Tank Vault & $\# 8$ & 366 & $\mathrm{U}$ & & HCJ-006-09 \\
\hline 2-Chlorophenol & E04808007013A & Tank Vault & $\# 9$ & 362 & $\mathrm{U}$ & & HCJ-006-09 \\
\hline 2-Chlorophenol & E04808008013A & Tank Vault & $\# 15$ & 355 & $\mathrm{U}$ & & HCJ-006-09 \\
\hline 2-Chlorophenol & E04808009013A & Tank Vault & $\# 24$ & 367 & $\mathrm{U}$ & & HCJ-006-09 \\
\hline 2-Chlorophenol & E04808010013A & Tank Vault & \#32 & 357 & $\mathrm{U}$ & & HCJ-006-09 \\
\hline 2-Methyl-4,6-dinitrophenol & E04808001013A & Pump Pit & $\# 3$ & 353 & $\mathrm{U}$ & & HCJ-006-09 \\
\hline 2-Methyl-4,6-dinitrophenol & E04808002013A & Pump Pit & $\# 12$ & 357 & $\mathrm{U}$ & & HCJ-006-09 \\
\hline 2-Methyl-4,6-dinitrophenol & E04808003013A & Pump Pit & $\# 16$ & 366 & $\mathrm{U}$ & & HCJ-006-09 \\
\hline 2-Methyl-4,6-dinitrophenol & E04808004013A & Pump Pit & $\# 18$ & 352 & $\mathrm{U}$ & & HCJ-006-09 \\
\hline 2-Methyl-4,6-dinitrophenol & E04808005013A & Pump Pit & \#23 & 348 & $\mathrm{U}$ & & HCJ-006-09 \\
\hline 2-Methyl-4,6-dinitrophenol & E04808006013A & Tank Vault & $\# 8$ & 366 & $\mathrm{U}$ & & HCJ-006-09 \\
\hline 2-Methyl-4,6-dinitrophenol & E04808007013A & Tank Vault & $\# 9$ & 362 & $\mathrm{U}$ & & HCJ-006-09 \\
\hline 2-Methyl-4,6-dinitrophenol & E04808008013A & Tank Vault & $\# 15$ & 355 & $\mathrm{U}$ & & HCJ-006-09 \\
\hline 2-Methyl-4,6-dinitrophenol & E04808009013A & Tank Vault & \#24 & 367 & $\mathrm{U}$ & & HCJ-006-09 \\
\hline 2-Methyl-4,6-dinitrophenol & E04808010013A & Tank Vault & \#32 & 357 & $\mathrm{U}$ & & HCJ-006-09 \\
\hline 2-Methylnaphthalene & E04808001013A & Pump Pit & \#3 & 35 & $\mathrm{U}$ & & HCJ-006-09 \\
\hline 2-Methylnaphthalene & E04808002013A & Pump Pit & $\# 12$ & 36 & $\mathrm{U}$ & & HCJ-006-09 \\
\hline 2-Methylnaphthalene & E04808003013A & Pump Pit & $\# 16$ & 37 & $\mathrm{U}$ & & HCJ-006-09 \\
\hline 2-Methylnaphthalene & E04808004013A & Pump Pit & $\# 18$ & 35 & $\mathrm{U}$ & & HCJ-006-09 \\
\hline 2-Methylnaphthalene & E04808005013A & Pump Pit & \#23 & 35 & $\mathrm{U}$ & & HCJ-006-09 \\
\hline 2-Methylnaphthalene & E04808006013A & Tank Vault & $\# 8$ & 37 & $\mathrm{U}$ & & HCJ-006-09 \\
\hline 2-Methylnaphthalene & E04808007013A & Tank Vault & $\# 9$ & 36 & $\mathrm{U}$ & & HCJ-006-09 \\
\hline 2-Methylnaphthalene & E04808008013A & Tank Vault & $\# 15$ & 36 & $\mathrm{U}$ & & HCJ-006-09 \\
\hline 2-Methylnaphthalene & E04808009013A & Tank Vault & \#24 & 37 & $\mathrm{U}$ & & HCJ-006-09 \\
\hline 2-Methylnaphthalene & E04808010013A & Tank Vault & \#32 & 36 & $\mathrm{U}$ & & HCJ-006-09 \\
\hline 2-Naphthylamine & E04808001013A & Pump Pit & $\# 3$ & 353 & $\mathrm{U}$ & & HCJ-006-09 \\
\hline 2-Naphthylamine & E04808002013A & Pump Pit & $\# 12$ & 357 & $\mathrm{U}$ & & HCJ-006-09 \\
\hline 2-Naphthylamine & E04808003013A & Pump Pit & $\# 16$ & 366 & $\mathrm{U}$ & & HCJ-006-09 \\
\hline 2-Naphthylamine & E04808004013A & Pump Pit & $\# 18$ & 352 & $\mathrm{U}$ & & HCJ-006-09 \\
\hline 2-Naphthylamine & E04808005013A & Pump Pit & \#23 & 348 & $\mathrm{U}$ & & HCJ-006-09 \\
\hline 2-Naphthylamine & E04808006013A & Tank Vault & $\# 8$ & 366 & $\mathrm{U}$ & & HCJ-006-09 \\
\hline 2-Naphthylamine & E04808007013A & Tank Vault & $\# 9$ & 362 & $\mathrm{U}$ & & HCJ-006-09 \\
\hline 2-Naphthylamine & E04808008013A & Tank Vault & $\# 15$ & 355 & $\mathrm{U}$ & & HCJ-006-09 \\
\hline 2-Naphthylamine & E04808009013A & Tank Vault & \#24 & 367 & $\mathrm{U}$ & & HCJ-006-09 \\
\hline 2-Naphthylamine & E04808010013A & Tank Vault & \#32 & 357 & $\mathrm{U}$ & & HCJ-006-09 \\
\hline 2-Nitrophenol & E04808001013A & Pump Pit & $\# 3$ & 353 & $\mathrm{U}$ & & HCJ-006-09 \\
\hline 2-Nitrophenol & E04808002013A & Pump Pit & $\# 12$ & 357 & $\mathrm{U}$ & & HCJ-006-09 \\
\hline 2-Nitrophenol & E04808003013A & Pump Pit & $\# 16$ & 366 & $\mathrm{U}$ & & HCJ-006-09 \\
\hline 2-Nitrophenol & E04808004013A & Pump Pit & $\# 18$ & 352 & $\mathrm{U}$ & & HCJ-006-09 \\
\hline 2-Nitrophenol & E04808005013A & Pump Pit & \#23 & 348 & $\mathrm{U}$ & & HCJ-006-09 \\
\hline 2-Nitrophenol & E04808006013A & Tank Vault & $\# 8$ & 366 & $\mathrm{U}$ & & HCJ-006-09 \\
\hline 2-Nitrophenol & E04808007013A & Tank Vault & $\# 9$ & 362 & $\mathrm{U}$ & & HCJ-006-09 \\
\hline 2-Nitrophenol & E04808008013A & Tank Vault & $\# 15$ & 355 & $\mathrm{U}$ & & HCJ-006-09 \\
\hline 2-Nitrophenol & E04808009013A & Tank Vault & \#24 & 367 & $\mathrm{U}$ & & HCJ-006-09 \\
\hline 2-Nitrophenol & E04808010013A & Tank Vault & \#32 & 357 & $\mathrm{U}$ & & HCJ-006-09 \\
\hline 2-Picoline & E04808001013A & Pump Pit & $\# 3$ & 353 & $\mathrm{U}$ & & HCJ-006-09 \\
\hline 2-Picoline & E04808002013A & Pump Pit & $\# 12$ & 357 & $\mathrm{U}$ & & HCJ-006-09 \\
\hline 2-Picoline & E04808003013A & Pump Pit & $\# 16$ & 366 & $\mathrm{U}$ & & HCJ-006-09 \\
\hline 2-Picoline & E04808004013A & Pump Pit & $\# 18$ & 352 & $\mathrm{U}$ & & HCJ-006-09 \\
\hline
\end{tabular}


Table G-4. (continued).

\begin{tabular}{|c|c|c|c|c|c|c|c|}
\hline Compound & $\begin{array}{l}\text { Field Sample } \\
\text { Number }\end{array}$ & Location & Grid & $\begin{array}{l}\text { Sample } \\
\text { Result } \\
(\mu \mathrm{g} / \mathrm{kg})\end{array}$ & $\begin{array}{l}\text { Result } \\
\text { Qual. }\end{array}$ & $\begin{array}{l}\text { Val. } \\
\text { Flag }\end{array}$ & $\begin{array}{l}\text { L\&V Report } \\
\text { Number }\end{array}$ \\
\hline 2-Picoline & E04808005013A & Pump Pit & $\# 23$ & 348 & $\mathrm{U}$ & & HCJ-006-09 \\
\hline 2-Picoline & E04808006013A & Tank Vault & $\# 8$ & 366 & $\mathrm{U}$ & & HCJ-006-09 \\
\hline 2-Picoline & E04808007013A & Tank Vault & $\# 9$ & 362 & $\mathrm{U}$ & & HCJ-006-09 \\
\hline 2-Picoline & E04808008013A & Tank Vault & $\# 15$ & 355 & $\mathrm{U}$ & & HCJ-006-09 \\
\hline 2-Picoline & E04808009013A & Tank Vault & \#24 & 367 & $\mathrm{U}$ & & HCJ-006-09 \\
\hline 2-Picoline & E04808010013A & Tank Vault & \#32 & 357 & $\mathrm{U}$ & & HCJ-006-09 \\
\hline 3,3'-Dichlorobenzidine & E04808001013A & Pump Pit & $\# 3$ & 353 & $\mathrm{U}$ & & HCJ-006-09 \\
\hline 3,3'-Dichlorobenzidine & E04808002013A & Pump Pit & $\# 12$ & 357 & $\mathrm{U}$ & & HCJ-006-09 \\
\hline 3,3'-Dichlorobenzidine & E04808003013A & Pump Pit & $\# 16$ & 366 & $\mathrm{U}$ & & HCJ-006-09 \\
\hline 3,3'-Dichlorobenzidine & E04808004013A & Pump Pit & $\# 18$ & 352 & $\mathrm{U}$ & & HCJ-006-09 \\
\hline 3,3'-Dichlorobenzidine & E04808005013A & Pump Pit & \#23 & 348 & $\mathrm{U}$ & & HCJ-006-09 \\
\hline 3,3'-Dichlorobenzidine & E04808006013A & Tank Vault & $\# 8$ & 366 & $\mathrm{U}$ & & HCJ-006-09 \\
\hline 3,3'-Dichlorobenzidine & E04808007013A & Tank Vault & $\# 9$ & 362 & $\mathrm{U}$ & & HCJ-006-09 \\
\hline 3,3'-Dichlorobenzidine & E04808008013A & Tank Vault & $\# 15$ & 355 & $\mathrm{U}$ & & HCJ-006-09 \\
\hline 3,3'-Dichlorobenzidine & E04808009013A & Tank Vault & $\# 24$ & 367 & $\mathrm{U}$ & & HCJ-006-09 \\
\hline 3,3'-Dichlorobenzidine & E04808010013A & Tank Vault & \#32 & 357 & $\mathrm{U}$ & & HCJ-006-09 \\
\hline 3,3'-Dimethylbenzidine & E04808001013A & Pump Pit & $\# 3$ & 353 & $\mathrm{U}$ & & HCJ-006-09 \\
\hline 3,3'-Dimethylbenzidine & E04808002013A & Pump Pit & \#12 & 357 & $\mathrm{U}$ & & HCJ-006-09 \\
\hline 3,3'-Dimethylbenzidine & E04808003013A & Pump Pit & $\# 16$ & 366 & $\mathrm{U}$ & & HCJ-006-09 \\
\hline 3,3'-Dimethylbenzidine & E04808004013A & Pump Pit & $\# 18$ & 352 & $\mathrm{U}$ & & HCJ-006-09 \\
\hline 3,3'-Dimethylbenzidine & E04808005013A & Pump Pit & \#23 & 348 & $\mathrm{U}$ & & HCJ-006-09 \\
\hline 3,3'-Dimethylbenzidine & E04808006013A & Tank Vault & $\# 8$ & 366 & $\mathrm{U}$ & & HCJ-006-09 \\
\hline 3,3'-Dimethylbenzidine & E04808007013A & Tank Vault & $\# 9$ & 362 & $\mathrm{U}$ & & HCJ-006-09 \\
\hline 3,3'-Dimethylbenzidine & E04808008013A & Tank Vault & $\# 15$ & 355 & $\mathrm{U}$ & & HCJ-006-09 \\
\hline 3,3'-Dimethylbenzidine & E04808009013A & Tank Vault & $\# 24$ & 367 & $\mathrm{U}$ & & HCJ-006-09 \\
\hline 3,3'-Dimethylbenzidine & E04808010013A & Tank Vault & \#32 & 357 & $\mathrm{U}$ & & HCJ-006-09 \\
\hline 3-Methylcholanthrene & E04808001013A & Pump Pit & $\# 3$ & 353 & $\mathrm{U}$ & & HCJ-006-09 \\
\hline 3-Methylcholanthrene & E04808002013A & Pump Pit & $\# 12$ & 357 & $\mathrm{U}$ & & HCJ-006-09 \\
\hline 3-Methylcholanthrene & E04808003013A & Pump Pit & $\# 16$ & 366 & $\mathrm{U}$ & & HCJ-006-09 \\
\hline 3-Methylcholanthrene & E04808004013A & Pump Pit & $\# 18$ & 352 & $\mathrm{U}$ & & HCJ-006-09 \\
\hline 3-Methylcholanthrene & E04808005013A & Pump Pit & \#23 & 348 & $\mathrm{U}$ & & HCJ-006-09 \\
\hline 3-Methylcholanthrene & E04808006013A & Tank Vault & $\# 8$ & 366 & $\mathrm{U}$ & & HCJ-006-09 \\
\hline 3-Methylcholanthrene & E04808007013A & Tank Vault & $\# 9$ & 362 & $\mathrm{U}$ & & HCJ-006-09 \\
\hline 3-Methylcholanthrene & E04808008013A & Tank Vault & $\# 15$ & 355 & $\mathrm{U}$ & & HCJ-006-09 \\
\hline 3-Methylcholanthrene & E04808009013A & Tank Vault & \#24 & 367 & $\mathrm{U}$ & & HCJ-006-09 \\
\hline 3-Methylcholanthrene & E04808010013A & Tank Vault & \#32 & 357 & $\mathrm{U}$ & & HCJ-006-09 \\
\hline 4-Aminobiphenyl & E04808001013A & Pump Pit & $\# 3$ & 353 & $\mathrm{U}$ & & HCJ-006-09 \\
\hline 4-Aminobiphenyl & E04808002013A & Pump Pit & $\# 12$ & 357 & $\mathrm{U}$ & & HCJ-006-09 \\
\hline 4-Aminobiphenyl & E04808003013A & Pump Pit & $\# 16$ & 366 & $\mathrm{U}$ & & HCJ-006-09 \\
\hline 4-Aminobiphenyl & E04808004013A & Pump Pit & $\# 18$ & 352 & $\mathrm{U}$ & & HCJ-006-09 \\
\hline 4-Aminobiphenyl & E04808005013A & Pump Pit & $\# 23$ & 348 & $\mathrm{U}$ & & HCJ-006-09 \\
\hline 4-Aminobiphenyl & E04808006013A & Tank Vault & $\# 8$ & 366 & $\mathrm{U}$ & & HCJ-006-09 \\
\hline 4-Aminobiphenyl & E04808007013A & Tank Vault & $\# 9$ & 362 & $\mathrm{U}$ & & HCJ-006-09 \\
\hline 4-Aminobiphenyl & E04808008013A & Tank Vault & $\# 15$ & 355 & $\mathrm{U}$ & & HCJ-006-09 \\
\hline 4-Aminobiphenyl & E04808009013A & Tank Vault & \#24 & 367 & $\mathrm{U}$ & & HCJ-006-09 \\
\hline 4-Aminobiphenyl & E04808010013A & Tank Vault & \#32 & 357 & $\mathrm{U}$ & & HCJ-006-09 \\
\hline 4-Bromophenyl phenyl ether & E04808001013A & Pump Pit & $\# 3$ & 353 & $\mathrm{U}$ & & HCJ-006-09 \\
\hline 4-Bromophenyl phenyl ether & E04808002013A & Pump Pit & $\# 12$ & 357 & $\mathrm{U}$ & & HCJ-006-09 \\
\hline 4-Bromophenyl phenyl ether & E04808003013A & Pump Pit & $\# 16$ & 366 & $\mathrm{U}$ & & HCJ-006-09 \\
\hline
\end{tabular}


Table G-4. (continued).

\begin{tabular}{|c|c|c|c|c|c|c|c|}
\hline Compound & $\begin{array}{c}\text { Field Sample } \\
\text { Number }\end{array}$ & Location & Grid & $\begin{array}{c}\text { Sample } \\
\text { Result } \\
(\mu \mathrm{g} / \mathrm{kg})\end{array}$ & $\begin{array}{l}\text { Result } \\
\text { Qual. }\end{array}$ & $\begin{array}{l}\text { Val. } \\
\text { Flag }\end{array}$ & $\begin{array}{c}\text { L\&V Report } \\
\text { Number }\end{array}$ \\
\hline 4-Bromophenyl phenyl ether & E04808004013A & Pump Pit & $\# 18$ & 352 & $\mathrm{U}$ & & HCJ-006-09 \\
\hline 4-Bromophenyl phenyl ether & E04808005013A & Pump Pit & \#23 & 348 & $\mathrm{U}$ & & HCJ-006-09 \\
\hline 4-Bromophenyl phenyl ether & E04808006013A & Tank Vault & $\# 8$ & 366 & $\mathrm{U}$ & & HCJ-006-09 \\
\hline 4-Bromophenyl phenyl ether & E04808007013A & Tank Vault & $\# 9$ & 362 & $\mathrm{U}$ & & HCJ-006-09 \\
\hline 4-Bromophenyl phenyl ether & E04808008013A & Tank Vault & $\# 15$ & 355 & $\mathrm{U}$ & & HCJ-006-09 \\
\hline 4-Bromophenyl phenyl ether & E04808009013A & Tank Vault & $\# 24$ & 367 & $\mathrm{U}$ & & HCJ-006-09 \\
\hline 4-Bromophenyl phenyl ether & E04808010013A & Tank Vault & \#32 & 357 & $\mathrm{U}$ & & HCJ-006-09 \\
\hline 4-Chloro-3-methylphenol & E04808001013A & Pump Pit & $\# 3$ & 353 & $\mathrm{U}$ & & HCJ-006-09 \\
\hline 4-Chloro-3-methylphenol & E04808002013A & Pump Pit & $\# 12$ & 357 & $\mathrm{U}$ & & HCJ-006-09 \\
\hline 4-Chloro-3-methylphenol & E04808003013A & Pump Pit & \#16 & 366 & $\mathrm{U}$ & & HCJ-006-09 \\
\hline 4-Chloro-3-methylphenol & E04808004013A & Pump Pit & $\# 18$ & 352 & $\mathrm{U}$ & & HCJ-006-09 \\
\hline 4-Chloro-3-methylphenol & E04808005013A & Pump Pit & \#23 & 348 & $\mathrm{U}$ & & HCJ-006-09 \\
\hline 4-Chloro-3-methylphenol & E04808006013A & Tank Vault & $\# 8$ & 366 & $\mathrm{U}$ & & HCJ-006-09 \\
\hline 4-Chloro-3-methylphenol & E04808007013A & Tank Vault & $\# 9$ & 362 & $\mathrm{U}$ & & HCJ-006-09 \\
\hline 4-Chloro-3-methylphenol & E04808008013A & Tank Vault & $\# 15$ & 355 & $\mathrm{U}$ & & HCJ-006-09 \\
\hline 4-Chloro-3-methylphenol & E04808009013A & Tank Vault & \#24 & 367 & $\mathrm{U}$ & & HCJ-006-09 \\
\hline 4-Chloro-3-methylphenol & E04808010013A & Tank Vault & \#32 & 357 & $\mathrm{U}$ & & HCJ-006-09 \\
\hline 4-Chloroaniline & E04808001013A & Pump Pit & $\# 3$ & 353 & $\mathrm{U}$ & & HCJ-006-09 \\
\hline 4-Chloroaniline & E04808002013A & Pump Pit & $\# 12$ & 357 & $\mathrm{U}$ & & HCJ-006-09 \\
\hline 4-Chloroaniline & E04808003013A & Pump Pit & $\# 16$ & 366 & $\mathrm{U}$ & & HCJ-006-09 \\
\hline 4-Chloroaniline & E04808004013A & Pump Pit & $\# 18$ & 352 & $\mathrm{U}$ & & HCJ-006-09 \\
\hline 4-Chloroaniline & E04808005013A & Pump Pit & \#23 & 348 & $\mathrm{U}$ & & HCJ-006-09 \\
\hline 4-Chloroaniline & E04808006013A & Tank Vault & $\# 8$ & 366 & $\mathrm{U}$ & & HCJ-006-09 \\
\hline 4-Chloroaniline & E04808007013A & Tank Vault & $\# 9$ & 362 & $\mathrm{U}$ & & HCJ-006-09 \\
\hline 4-Chloroaniline & E04808008013A & Tank Vault & $\# 15$ & 355 & $\mathrm{U}$ & & HCJ-006-09 \\
\hline 4-Chloroaniline & E04808009013A & Tank Vault & $\# 24$ & 367 & $\mathrm{U}$ & & HCJ-006-09 \\
\hline 4-Chloroaniline & E04808010013A & Tank Vault & \#32 & 357 & $\mathrm{U}$ & & HCJ-006-09 \\
\hline 4-Chlorophenyl phenyl ether & E04808001013A & Pump Pit & $\# 3$ & 353 & $\mathrm{U}$ & & HCJ-006-09 \\
\hline 4-Chlorophenyl phenyl ether & E04808002013A & Pump Pit & $\# 12$ & 357 & $\mathrm{U}$ & & HCJ-006-09 \\
\hline 4-Chlorophenyl phenyl ether & E04808003013A & Pump Pit & $\# 16$ & 366 & $\mathrm{U}$ & & HCJ-006-09 \\
\hline 4-Chlorophenyl phenyl ether & E04808004013A & Pump Pit & $\# 18$ & 352 & $\mathrm{U}$ & & HCJ-006-09 \\
\hline 4-Chlorophenyl phenyl ether & E04808005013A & Pump Pit & \#23 & 348 & $\mathrm{U}$ & & HCJ-006-09 \\
\hline 4-Chlorophenyl phenyl ether & E04808006013A & Tank Vault & $\# 8$ & 366 & $\mathrm{U}$ & & HCJ-006-09 \\
\hline 4-Chlorophenyl phenyl ether & E04808007013A & Tank Vault & $\# 9$ & 362 & $\mathrm{U}$ & & HCJ-006-09 \\
\hline 4-Chlorophenyl phenyl ether & E04808008013A & Tank Vault & $\# 15$ & 355 & $\mathrm{U}$ & & HCJ-006-09 \\
\hline 4-Chlorophenyl phenyl ether & E04808009013A & Tank Vault & \#24 & 367 & $\mathrm{U}$ & & HCJ-006-09 \\
\hline 4-Chlorophenyl phenyl ether & E04808010013A & Tank Vault & \#32 & 357 & $\mathrm{U}$ & & HCJ-006-09 \\
\hline 4-Nitrophenol & E04808001013A & Pump Pit & $\# 3$ & 353 & $\mathrm{U}$ & & HCJ-006-09 \\
\hline 4-Nitrophenol & E04808002013A & Pump Pit & $\# 12$ & 357 & $\mathrm{U}$ & & HCJ-006-09 \\
\hline 4-Nitrophenol & E04808003013A & Pump Pit & $\# 16$ & 366 & $\mathrm{U}$ & & HCJ-006-09 \\
\hline 4-Nitrophenol & E04808004013A & Pump Pit & \#18 & 352 & $\mathrm{U}$ & & HCJ-006-09 \\
\hline 4-Nitrophenol & E04808005013A & Pump Pit & \#23 & 348 & $\mathrm{U}$ & & HCJ-006-09 \\
\hline 4-Nitrophenol & E04808006013A & Tank Vault & $\# 8$ & 366 & $\mathrm{U}$ & & HCJ-006-09 \\
\hline 4-Nitrophenol & E04808007013A & Tank Vault & $\# 9$ & 362 & $\mathrm{U}$ & & HCJ-006-09 \\
\hline 4-Nitrophenol & E04808008013A & Tank Vault & $\# 15$ & 355 & $\mathrm{U}$ & & HCJ-006-09 \\
\hline 4-Nitrophenol & E04808009013A & Tank Vault & \#24 & 367 & $\mathrm{U}$ & & HCJ-006-09 \\
\hline 4-Nitrophenol & E04808010013A & Tank Vault & \#32 & 357 & $\mathrm{U}$ & & HCJ-006-09 \\
\hline 4-Nitroquinoline 1-oxide & E04808001013A & Pump Pit & $\# 3$ & 353 & $\mathrm{U}$ & $\mathrm{R}$ & HCJ-006-09 \\
\hline 4-Nitroquinoline 1-oxide & E04808002013A & Pump Pit & $\# 12$ & 357 & $\mathrm{U}$ & $\mathrm{R}$ & HCJ-006-09 \\
\hline
\end{tabular}


Table G-4. (continued).

\begin{tabular}{|c|c|c|c|c|c|c|c|}
\hline Compound & $\begin{array}{c}\text { Field Sample } \\
\text { Number }\end{array}$ & Location & Grid & $\begin{array}{c}\text { Sample } \\
\text { Result } \\
(\mu \mathrm{g} / \mathrm{kg})\end{array}$ & $\begin{array}{l}\text { Result } \\
\text { Qual. }\end{array}$ & $\begin{array}{l}\text { Val. } \\
\text { Flag }\end{array}$ & $\begin{array}{c}\text { L\&V Report } \\
\text { Number }\end{array}$ \\
\hline 4-Nitroquinoline 1-oxide & E04808003013A & Pump Pit & $\# 16$ & 366 & $\mathrm{U}$ & $\mathrm{R}$ & HCJ-006-09 \\
\hline 4-Nitroquinoline 1-oxide & E04808004013A & Pump Pit & $\# 18$ & 352 & $\mathrm{U}$ & $\mathrm{R}$ & HCJ-006-09 \\
\hline 4-Nitroquinoline 1-oxide & E04808005013A & Pump Pit & \#23 & 348 & $\mathrm{U}$ & $\mathrm{R}$ & HCJ-006-09 \\
\hline 4-Nitroquinoline 1-oxide & E04808006013A & Tank Vault & $\# 8$ & 366 & $\mathrm{U}$ & $\mathrm{R}$ & HCJ-006-09 \\
\hline 4-Nitroquinoline 1-oxide & E04808007013A & Tank Vault & $\# 9$ & 362 & $\mathrm{U}$ & $\mathrm{R}$ & HCJ-006-09 \\
\hline 4-Nitroquinoline 1-oxide & E04808008013A & Tank Vault & $\# 15$ & 355 & $\mathrm{U}$ & $\mathrm{R}$ & HCJ-006-09 \\
\hline 4-Nitroquinoline 1-oxide & E04808009013A & Tank Vault & $\# 24$ & 367 & $\mathrm{U}$ & $\mathrm{R}$ & HCJ-006-09 \\
\hline 4-Nitroquinoline 1-oxide & E04808010013A & Tank Vault & \#32 & 357 & $\mathrm{U}$ & $\mathrm{R}$ & HCJ-006-09 \\
\hline 5-Nitro-o-toluidine & E04808001013A & Pump Pit & $\# 3$ & 353 & $\mathrm{U}$ & & HCJ-006-09 \\
\hline 5-Nitro-o-toluidine & E04808002013A & Pump Pit & $\# 12$ & 357 & $\mathrm{U}$ & & HCJ-006-09 \\
\hline 5-Nitro-o-toluidine & E04808003013A & Pump Pit & $\# 16$ & 366 & $\mathrm{U}$ & & HCJ-006-09 \\
\hline 5-Nitro-o-toluidine & E04808004013A & Pump Pit & $\# 18$ & 352 & $\mathrm{U}$ & & HCJ-006-09 \\
\hline 5-Nitro-o-toluidine & E04808005013A & Pump Pit & \#23 & 348 & $\mathrm{U}$ & & HCJ-006-09 \\
\hline 5-Nitro-o-toluidine & E04808006013A & Tank Vault & $\# 8$ & 366 & $\mathrm{U}$ & & HCJ-006-09 \\
\hline 5-Nitro-o-toluidine & E04808007013A & Tank Vault & $\# 9$ & 362 & $\mathrm{U}$ & & HCJ-006-09 \\
\hline 5-Nitro-o-toluidine & E04808008013A & Tank Vault & $\# 15$ & 355 & $\mathrm{U}$ & & HCJ-006-09 \\
\hline 5-Nitro-o-toluidine & E04808009013A & Tank Vault & $\# 24$ & 367 & $\mathrm{U}$ & & HCJ-006-09 \\
\hline 5-Nitro-o-toluidine & E04808010013A & Tank Vault & \#32 & 357 & $\mathrm{U}$ & & HCJ-006-09 \\
\hline 7,12-Dimethylbenz(a)anthracene & E04808001013A & Pump Pit & $\# 3$ & 353 & $\mathrm{U}$ & & HCJ-006-09 \\
\hline 7,12-Dimethylbenz(a)anthracene & E04808002013A & Pump Pit & $\# 12$ & 357 & $\mathrm{U}$ & & HCJ-006-09 \\
\hline 7,12-Dimethylbenz(a)anthracene & E04808003013A & Pump Pit & $\# 16$ & 366 & $\mathrm{U}$ & & HCJ-006-09 \\
\hline 7,12-Dimethylbenz(a)anthracene & E04808004013A & Pump Pit & $\# 18$ & 352 & $\mathrm{U}$ & & HCJ-006-09 \\
\hline 7,12-Dimethylbenz(a)anthracene & E04808005013A & Pump Pit & \#23 & 348 & $\mathrm{U}$ & & HCJ-006-09 \\
\hline 7,12-Dimethylbenz(a)anthracene & E04808006013A & Tank Vault & $\# 8$ & 366 & $\mathrm{U}$ & & HCJ-006-09 \\
\hline 7,12-Dimethylbenz(a)anthracene & E04808007013A & Tank Vault & $\# 9$ & 362 & $\mathrm{U}$ & & HCJ-006-09 \\
\hline 7,12-Dimethylbenz(a)anthracene & E04808008013A & Tank Vault & $\# 15$ & 355 & $\mathrm{U}$ & & HCJ-006-09 \\
\hline 7,12-Dimethylbenz(a)anthracene & E04808009013A & Tank Vault & $\# 24$ & 367 & $\mathrm{U}$ & & HCJ-006-09 \\
\hline 7,12-Dimethylbenz(a)anthracene & E04808010013A & Tank Vault & \#32 & 357 & $\mathrm{U}$ & & HCJ-006-09 \\
\hline a,a,-Dimethylphenethylamine & E04808001013A & Pump Pit & $\# 3$ & 353 & $\mathrm{U}$ & & HCJ-006-09 \\
\hline a,a,-Dimethylphenethylamine & E04808002013A & Pump Pit & $\# 12$ & 357 & $\mathrm{U}$ & & HCJ-006-09 \\
\hline a,a,-Dimethylphenethylamine & E04808003013A & Pump Pit & $\# 16$ & 366 & $\mathrm{U}$ & & HCJ-006-09 \\
\hline a,a,-Dimethylphenethylamine & E04808004013A & Pump Pit & $\# 18$ & 352 & $\mathrm{U}$ & & HCJ-006-09 \\
\hline a,a,-Dimethylphenethylamine & E04808005013A & Pump Pit & \#23 & 348 & $\mathrm{U}$ & & HCJ-006-09 \\
\hline a,a,-Dimethylphenethylamine & E04808006013A & Tank Vault & $\# 8$ & 366 & $\mathrm{U}$ & & HCJ-006-09 \\
\hline a,a,-Dimethylphenethylamine & E04808007013A & Tank Vault & $\# 9$ & 362 & $\mathrm{U}$ & & HCJ-006-09 \\
\hline a,a,-Dimethylphenethylamine & E04808008013A & Tank Vault & $\# 15$ & 355 & $\mathrm{U}$ & & HCJ-006-09 \\
\hline a,a,-Dimethylphenethylamine & E04808009013A & Tank Vault & $\# 24$ & 367 & $\mathrm{U}$ & & HCJ-006-09 \\
\hline a,a,-Dimethylphenethylamine & E04808010013A & Tank Vault & \#32 & 357 & $\mathrm{U}$ & & HCJ-006-09 \\
\hline Acenaphthene & E04808001013A & Pump Pit & $\# 3$ & 35 & $\mathrm{U}$ & & HCJ-006-09 \\
\hline Acenaphthene & E04808002013A & Pump Pit & $\# 12$ & 36 & $\mathrm{U}$ & & HCJ-006-09 \\
\hline Acenaphthene & E04808003013A & Pump Pit & \#16 & 37 & $\mathrm{U}$ & & HCJ-006-09 \\
\hline Acenaphthene & E04808004013A & Pump Pit & $\# 18$ & 35 & $\mathrm{U}$ & & HCJ-006-09 \\
\hline Acenaphthene & E04808005013A & Pump Pit & \#23 & 35 & $\mathrm{U}$ & & HCJ-006-09 \\
\hline Acenaphthene & E04808006013A & Tank Vault & $\# 8$ & 37 & $\mathrm{U}$ & & HCJ-006-09 \\
\hline Acenaphthene & E04808007013A & Tank Vault & $\# 9$ & 36 & $\mathrm{U}$ & & HCJ-006-09 \\
\hline Acenaphthene & E04808008013A & Tank Vault & $\# 15$ & 36 & $\mathrm{U}$ & & HCJ-006-09 \\
\hline Acenaphthene & E04808009013A & Tank Vault & $\# 24$ & 37 & $\mathrm{U}$ & & HCJ-006-09 \\
\hline Acenaphthene & E04808010013A & Tank Vault & \#32 & 36 & $\mathrm{U}$ & & HCJ-006-09 \\
\hline Acenaphthylene & E04808001013A & Pump Pit & $\# 3$ & 35 & $\mathrm{U}$ & & HCJ-006-09 \\
\hline
\end{tabular}


Table G-4. (continued).

\begin{tabular}{|c|c|c|c|c|c|c|c|}
\hline Compound & $\begin{array}{c}\text { Field Sample } \\
\text { Number }\end{array}$ & Location & Grid & $\begin{array}{c}\text { Sample } \\
\text { Result } \\
(\mu \mathrm{g} / \mathrm{kg})\end{array}$ & $\begin{array}{l}\text { Result } \\
\text { Qual. }\end{array}$ & $\begin{array}{l}\text { Val. } \\
\text { Flag }\end{array}$ & $\begin{array}{c}\text { L\&V Report } \\
\text { Number }\end{array}$ \\
\hline Acenaphthylene & E04808002013A & Pump Pit & $\# 12$ & 36 & $\mathrm{U}$ & & HCJ-006-09 \\
\hline Acenaphthylene & E04808003013A & Pump Pit & $\# 16$ & 37 & $\mathrm{U}$ & & HCJ-006-09 \\
\hline Acenaphthylene & E04808004013A & Pump Pit & $\# 18$ & 35 & $\mathrm{U}$ & & HCJ-006-09 \\
\hline Acenaphthylene & E04808005013A & Pump Pit & \#23 & 35 & $\mathrm{U}$ & & HCJ-006-09 \\
\hline Acenaphthylene & E04808006013A & Tank Vault & $\# 8$ & 37 & $\mathrm{U}$ & & HCJ-006-09 \\
\hline Acenaphthylene & E04808007013A & Tank Vault & $\# 9$ & 36 & $\mathrm{U}$ & & HCJ-006-09 \\
\hline Acenaphthylene & E04808008013A & Tank Vault & \#15 & 36 & $\mathrm{U}$ & & HCJ-006-09 \\
\hline Acenaphthylene & E04808009013A & Tank Vault & $\# 24$ & 37 & $\mathrm{U}$ & & HCJ-006-09 \\
\hline Acenaphthylene & E04808010013A & Tank Vault & \#32 & 36 & $\mathrm{U}$ & & HCJ-006-09 \\
\hline Acetophenone & E04808001013A & Pump Pit & \#3 & 353 & $\mathrm{U}$ & & HCJ-006-09 \\
\hline Acetophenone & E04808002013A & Pump Pit & $\# 12$ & 357 & $\mathrm{U}$ & & HCJ-006-09 \\
\hline Acetophenone & E04808003013A & Pump Pit & $\# 16$ & 366 & $\mathrm{U}$ & & HCJ-006-09 \\
\hline Acetophenone & E04808004013A & Pump Pit & $\# 18$ & 352 & $\mathrm{U}$ & & HCJ-006-09 \\
\hline Acetophenone & E04808005013A & Pump Pit & \#23 & 348 & $\mathrm{U}$ & & HCJ-006-09 \\
\hline Acetophenone & E04808006013A & Tank Vault & \#8 & 366 & $\mathrm{U}$ & & HCJ-006-09 \\
\hline Acetophenone & E04808007013A & Tank Vault & $\# 9$ & 362 & $\mathrm{U}$ & & HCJ-006-09 \\
\hline Acetophenone & E04808008013A & Tank Vault & $\# 15$ & 355 & $\mathrm{U}$ & & HCJ-006-09 \\
\hline Acetophenone & E04808009013A & Tank Vault & $\# 24$ & 367 & $\mathrm{U}$ & & HCJ-006-09 \\
\hline Acetophenone & E04808010013A & Tank Vault & \#32 & 357 & $\mathrm{U}$ & & HCJ-006-09 \\
\hline Aniline & E04808001013A & Pump Pit & $\# 3$ & 353 & $\mathrm{U}$ & & HCJ-006-09 \\
\hline Aniline & E04808002013A & Pump Pit & \#12 & 357 & $\mathrm{U}$ & & HCJ-006-09 \\
\hline Aniline & E04808003013A & Pump Pit & $\# 16$ & 366 & $\mathrm{U}$ & & HCJ-006-09 \\
\hline Aniline & E04808004013A & Pump Pit & $\# 18$ & 352 & $\mathrm{U}$ & & HCJ-006-09 \\
\hline Aniline & E04808005013A & Pump Pit & \#23 & 348 & $\mathrm{U}$ & & HCJ-006-09 \\
\hline Aniline & E04808006013A & Tank Vault & $\# 8$ & 366 & $\mathrm{U}$ & & HCJ-006-09 \\
\hline Aniline & E04808007013A & Tank Vault & $\# 9$ & 362 & $\mathrm{U}$ & & HCJ-006-09 \\
\hline Aniline & E04808008013A & Tank Vault & \#15 & 355 & $\mathrm{U}$ & & HCJ-006-09 \\
\hline Aniline & E04808009013A & Tank Vault & \#24 & 367 & $\mathrm{U}$ & & HCJ-006-09 \\
\hline Aniline & E04808010013A & Tank Vault & \#32 & 357 & $\mathrm{U}$ & & HCJ-006-09 \\
\hline Anthracene & E04808001013A & Pump Pit & $\# 3$ & 35 & $\mathrm{U}$ & & HCJ-006-09 \\
\hline Anthracene & E04808002013A & Pump Pit & $\# 12$ & 36 & $\mathrm{U}$ & & HCJ-006-09 \\
\hline Anthracene & E04808003013A & Pump Pit & $\# 16$ & 37 & $\mathrm{U}$ & & HCJ-006-09 \\
\hline Anthracene & E04808004013A & Pump Pit & $\# 18$ & 35 & $\mathrm{U}$ & & HCJ-006-09 \\
\hline Anthracene & E04808005013A & Pump Pit & \#23 & 35 & $\mathrm{U}$ & & HCJ-006-09 \\
\hline Anthracene & E04808006013A & Tank Vault & $\# 8$ & 37 & $\mathrm{U}$ & & HCJ-006-09 \\
\hline Anthracene & E04808007013A & Tank Vault & $\# 9$ & 36 & $\mathrm{U}$ & & HCJ-006-09 \\
\hline Anthracene & E04808008013A & Tank Vault & $\# 15$ & 36 & $\mathrm{U}$ & & HCJ-006-09 \\
\hline Anthracene & E04808009013A & Tank Vault & \#24 & 37 & $\mathrm{U}$ & & HCJ-006-09 \\
\hline Anthracene & E04808010013A & Tank Vault & \#32 & 36 & $\mathrm{U}$ & & HCJ-006-09 \\
\hline Aramite & E04808001013A & Pump Pit & $\# 3$ & 353 & $\mathrm{U}$ & $\mathrm{R}$ & HCJ-006-09 \\
\hline Aramite & E04808002013A & Pump Pit & $\# 12$ & 357 & $\mathrm{U}$ & $\mathrm{R}$ & HCJ-006-09 \\
\hline Aramite & E04808003013A & Pump Pit & $\# 16$ & 366 & $\mathrm{U}$ & $\mathrm{R}$ & HCJ-006-09 \\
\hline Aramite & E04808004013A & Pump Pit & $\# 18$ & 352 & $\mathrm{U}$ & $\mathrm{R}$ & HCJ-006-09 \\
\hline Aramite & E04808005013A & Pump Pit & \#23 & 348 & $\mathrm{U}$ & $\mathrm{R}$ & HCJ-006-09 \\
\hline Aramite & E04808006013A & Tank Vault & $\# 8$ & 366 & $\mathrm{U}$ & $\mathrm{R}$ & HCJ-006-09 \\
\hline Aramite & E04808007013A & Tank Vault & $\# 9$ & 362 & $\mathrm{U}$ & $\mathrm{R}$ & HCJ-006-09 \\
\hline Aramite & E04808008013A & Tank Vault & $\# 15$ & 355 & $\mathrm{U}$ & & HCJ-006-09 \\
\hline Aramite & E04808009013A & Tank Vault & \#24 & 367 & $\mathrm{U}$ & $\mathrm{R}$ & HCJ-006-09 \\
\hline Aramite & E04808010013A & Tank Vault & \#32 & 357 & $\mathrm{U}$ & $\mathrm{R}$ & HCJ-006-09 \\
\hline
\end{tabular}


Table G-4. (continued).

\begin{tabular}{|c|c|c|c|c|c|c|c|}
\hline Compound & $\begin{array}{l}\text { Field Sample } \\
\text { Number }\end{array}$ & Location & Grid & $\begin{array}{l}\text { Sample } \\
\text { Result } \\
(\mu \mathrm{g} / \mathrm{kg})\end{array}$ & $\begin{array}{l}\text { Result } \\
\text { Qual. }\end{array}$ & $\begin{array}{l}\text { Val. } \\
\text { Flag }\end{array}$ & $\begin{array}{l}\text { L\&V Report } \\
\text { Number }\end{array}$ \\
\hline Benzo(a)anthracene & E04808001013A & Pump Pit & $\# 3$ & 35 & $\mathrm{U}$ & & HCJ-006-09 \\
\hline Benzo(a)anthracene & E04808002013A & Pump Pit & $\# 12$ & 36 & $\mathrm{U}$ & & HCJ-006-09 \\
\hline Benzo(a)anthracene & E04808003013A & Pump Pit & $\# 16$ & 37 & $\mathrm{U}$ & & HCJ-006-09 \\
\hline Benzo(a)anthracene & E04808004013A & Pump Pit & $\# 18$ & 35 & $\mathrm{U}$ & & HCJ-006-09 \\
\hline Benzo(a)anthracene & E04808005013A & Pump Pit & \#23 & 35 & $\mathrm{U}$ & & HCJ-006-09 \\
\hline Benzo(a)anthracene & E04808006013A & Tank Vault & $\# 8$ & 37 & $\mathrm{U}$ & & HCJ-006-09 \\
\hline Benzo(a)anthracene & E04808007013A & Tank Vault & $\# 9$ & 36 & $\mathrm{U}$ & & HCJ-006-09 \\
\hline Benzo(a)anthracene & E04808008013A & Tank Vault & $\# 15$ & 36 & $\mathrm{U}$ & & HCJ-006-09 \\
\hline Benzo(a)anthracene & E04808009013A & Tank Vault & \#24 & 37 & $\mathrm{U}$ & & HCJ-006-09 \\
\hline Benzo(a)anthracene & E04808010013A & Tank Vault & \#32 & 36 & $\mathrm{U}$ & & HCJ-006-09 \\
\hline Benzo(a)pyrene & E04808001013A & Pump Pit & $\# 3$ & 35 & $\mathrm{U}$ & & HCJ-006-09 \\
\hline Benzo(a)pyrene & E04808002013A & Pump Pit & $\# 12$ & 36 & $\mathrm{U}$ & & HCJ-006-09 \\
\hline Benzo(a)pyrene & E04808003013A & Pump Pit & $\# 16$ & 37 & $\mathrm{U}$ & & HCJ-006-09 \\
\hline Benzo(a)pyrene & E04808004013A & Pump Pit & $\# 18$ & 35 & $\mathrm{U}$ & & HCJ-006-09 \\
\hline Benzo(a)pyrene & E04808005013A & Pump Pit & \#23 & 35 & $\mathrm{U}$ & & HCJ-006-09 \\
\hline Benzo(a)pyrene & E04808006013A & Tank Vault & $\# 8$ & 37 & $\mathrm{U}$ & & HCJ-006-09 \\
\hline Benzo(a)pyrene & E04808007013A & Tank Vault & $\# 9$ & 36 & $\mathrm{U}$ & & HCJ-006-09 \\
\hline Benzo(a)pyrene & E04808008013A & Tank Vault & $\# 15$ & 36 & $\mathrm{U}$ & & HCJ-006-09 \\
\hline Benzo(a)pyrene & E04808009013A & Tank Vault & \#24 & 37 & $\mathrm{U}$ & & HCJ-006-09 \\
\hline Benzo(a)pyrene & E04808010013A & Tank Vault & \#32 & 36 & $\mathrm{U}$ & & HCJ-006-09 \\
\hline Benzo(b)fluoranthene & E04808001013A & Pump Pit & $\# 3$ & 35 & $\mathrm{U}$ & & HCJ-006-09 \\
\hline Benzo(b)fluoranthene & E04808002013A & Pump Pit & $\# 12$ & 36 & $\mathrm{U}$ & & HCJ-006-09 \\
\hline Benzo(b)fluoranthene & E04808003013A & Pump Pit & $\# 16$ & 37 & $\mathrm{U}$ & & HCJ-006-09 \\
\hline Benzo(b)fluoranthene & E04808004013A & Pump Pit & $\# 18$ & 35 & $\mathrm{U}$ & & HCJ-006-09 \\
\hline Benzo(b)fluoranthene & E04808005013A & Pump Pit & \#23 & 35 & $\mathrm{U}$ & & HCJ-006-09 \\
\hline Benzo(b)fluoranthene & E04808006013A & Tank Vault & $\# 8$ & 37 & $\mathrm{U}$ & & HCJ-006-09 \\
\hline Benzo(b)fluoranthene & E04808007013A & Tank Vault & $\# 9$ & 36 & $\mathrm{U}$ & & HCJ-006-09 \\
\hline Benzo(b)fluoranthene & E04808008013A & Tank Vault & $\# 15$ & 36 & $\mathrm{U}$ & & HCJ-006-09 \\
\hline Benzo(b)fluoranthene & E04808009013A & Tank Vault & \#24 & 37 & $\mathrm{U}$ & & HCJ-006-09 \\
\hline Benzo(b)fluoranthene & E04808010013A & Tank Vault & \#32 & 36 & $\mathrm{U}$ & & HCJ-006-09 \\
\hline Benzo(g,h,i)perylene & E04808001013A & Pump Pit & $\# 3$ & 35 & $\mathrm{U}$ & & HCJ-006-09 \\
\hline Benzo(g,h,i)perylene & E04808002013A & Pump Pit & $\# 12$ & 36 & $\mathrm{U}$ & & HCJ-006-09 \\
\hline Benzo(g,h,i)perylene & E04808003013A & Pump Pit & $\# 16$ & 37 & $\mathrm{U}$ & & HCJ-006-09 \\
\hline Benzo(g,h,i)perylene & E04808004013A & Pump Pit & $\# 18$ & 35 & $\mathrm{U}$ & & HCJ-006-09 \\
\hline Benzo(g,h,i)perylene & E04808005013A & Pump Pit & \#23 & 35 & $\mathrm{U}$ & & HCJ-006-09 \\
\hline Benzo(g,h,i)perylene & E04808006013A & Tank Vault & $\# 8$ & 37 & $\mathrm{U}$ & & HCJ-006-09 \\
\hline Benzo(g,h,i)perylene & E04808007013A & Tank Vault & $\# 9$ & 36 & $\mathrm{U}$ & & HCJ-006-09 \\
\hline Benzo(g,h,i)perylene & E04808008013A & Tank Vault & $\# 15$ & 36 & $\mathrm{U}$ & & HCJ-006-09 \\
\hline Benzo(g,h,i)perylene & E04808009013A & Tank Vault & \#24 & 37 & $\mathrm{U}$ & & HCJ-006-09 \\
\hline Benzo(g,h,i)perylene & E04808010013A & Tank Vault & \#32 & 36 & $\mathrm{U}$ & & HCJ-006-09 \\
\hline Benzo(k)fluoranthene & E04808001013A & Pump Pit & $\# 3$ & 35 & $\mathrm{U}$ & & HCJ-006-09 \\
\hline Benzo(k)fluoranthene & E04808002013A & Pump Pit & $\# 12$ & 36 & $\mathrm{U}$ & & HCJ-006-09 \\
\hline Benzo(k)fluoranthene & E04808003013A & Pump Pit & $\# 16$ & 37 & $\mathrm{U}$ & & HCJ-006-09 \\
\hline Benzo(k)fluoranthene & E04808004013A & Pump Pit & $\# 18$ & 35 & $\mathrm{U}$ & & HCJ-006-09 \\
\hline Benzo(k)fluoranthene & E04808005013A & Pump Pit & \#23 & 35 & $\mathrm{U}$ & & HCJ-006-09 \\
\hline Benzo(k)fluoranthene & E04808006013A & Tank Vault & $\# 8$ & 37 & $\mathrm{U}$ & & HCJ-006-09 \\
\hline Benzo(k)fluoranthene & E04808007013A & Tank Vault & $\# 9$ & 36 & $\mathrm{U}$ & & HCJ-006-09 \\
\hline Benzo(k)fluoranthene & E04808008013A & Tank Vault & $\# 15$ & 36 & $\mathrm{U}$ & & HCJ-006-09 \\
\hline Benzo(k)fluoranthene & E04808009013A & Tank Vault & $\# 24$ & 37 & $\mathrm{U}$ & & HCJ-006-09 \\
\hline
\end{tabular}


Table G-4. (continued).

\begin{tabular}{|c|c|c|c|c|c|c|c|}
\hline Compound & $\begin{array}{l}\text { Field Sample } \\
\text { Number }\end{array}$ & Location & Grid & $\begin{array}{l}\text { Sample } \\
\text { Result } \\
(\mu \mathrm{g} / \mathrm{kg})\end{array}$ & $\begin{array}{l}\text { Result } \\
\text { Qual. }\end{array}$ & $\begin{array}{l}\text { Val. } \\
\text { Flag }\end{array}$ & $\begin{array}{l}\text { L\&V Report } \\
\text { Number }\end{array}$ \\
\hline Benzo(k)fluoranthene & E04808010013A & Tank Vault & $\# 32$ & 36 & $\mathrm{U}$ & & HCJ-006-09 \\
\hline Benzyl alcohol & E04808001013A & Pump Pit & $\# 3$ & 353 & $\mathrm{U}$ & & HCJ-006-09 \\
\hline Benzyl alcohol & E04808002013A & Pump Pit & $\# 12$ & 357 & $\mathrm{U}$ & & HCJ-006-09 \\
\hline Benzyl alcohol & E04808003013A & Pump Pit & $\# 16$ & 366 & $\mathrm{U}$ & & HCJ-006-09 \\
\hline Benzyl alcohol & E04808004013A & Pump Pit & \#18 & 352 & $\mathrm{U}$ & & HCJ-006-09 \\
\hline Benzyl alcohol & E04808005013A & Pump Pit & $\# 23$ & 348 & $\mathrm{U}$ & & HCJ-006-09 \\
\hline Benzyl alcohol & E04808006013A & Tank Vault & $\# 8$ & 366 & $\mathrm{U}$ & & HCJ-006-09 \\
\hline Benzyl alcohol & E04808007013A & Tank Vault & $\# 9$ & 362 & $\mathrm{U}$ & & HCJ-006-09 \\
\hline Benzyl alcohol & E04808008013A & Tank Vault & $\# 15$ & 355 & $\mathrm{U}$ & & HCJ-006-09 \\
\hline Benzyl alcohol & E04808009013A & Tank Vault & \#24 & 367 & $\mathrm{U}$ & & HCJ-006-09 \\
\hline Benzyl alcohol & E04808010013A & Tank Vault & \#32 & 357 & $\mathrm{U}$ & & HCJ-006-09 \\
\hline bis-(2-chloroethoxy)methane & E04808001013A & Pump Pit & $\# 3$ & 353 & $\mathrm{U}$ & & HCJ-006-09 \\
\hline bis-(2-chloroethoxy)methane & E04808002013A & Pump Pit & $\# 12$ & 357 & $\mathrm{U}$ & & HCJ-006-09 \\
\hline bis-(2-chloroethoxy)methane & E04808003013A & Pump Pit & $\# 16$ & 366 & $\mathrm{U}$ & & HCJ-006-09 \\
\hline bis-(2-chloroethoxy)methane & E04808004013A & Pump Pit & \#18 & 352 & $\mathrm{U}$ & & HCJ-006-09 \\
\hline bis-(2-chloroethoxy)methane & E04808005013A & Pump Pit & \#23 & 348 & $\mathrm{U}$ & & HCJ-006-09 \\
\hline bis-(2-chloroethoxy)methane & E04808006013A & Tank Vault & $\# 8$ & 366 & $\mathrm{U}$ & & HCJ-006-09 \\
\hline bis-(2-chloroethoxy)methane & E04808007013A & Tank Vault & $\# 9$ & 362 & $\mathrm{U}$ & & HCJ-006-09 \\
\hline bis-(2-chloroethoxy)methane & E04808008013A & Tank Vault & $\# 15$ & 355 & $\mathrm{U}$ & & HCJ-006-09 \\
\hline bis-(2-chloroethoxy)methane & E04808009013A & Tank Vault & \#24 & 367 & $\mathrm{U}$ & & HCJ-006-09 \\
\hline bis-(2-chloroethoxy)methane & E04808010013A & Tank Vault & \#32 & 357 & $\mathrm{U}$ & & HCJ-006-09 \\
\hline bis-(2-Chloroethyl)ether & E04808001013A & Pump Pit & \#3 & 353 & $\mathrm{U}$ & & HCJ-006-09 \\
\hline bis-(2-Chloroethyl)ether & E04808002013A & Pump Pit & $\# 12$ & 357 & $\mathrm{U}$ & & HCJ-006-09 \\
\hline bis-(2-Chloroethyl)ether & E04808003013A & Pump Pit & $\# 16$ & 366 & $\mathrm{U}$ & & HCJ-006-09 \\
\hline bis-(2-Chloroethyl)ether & E04808004013A & Pump Pit & $\# 18$ & 352 & $\mathrm{U}$ & & HCJ-006-09 \\
\hline bis-(2-Chloroethyl)ether & E04808005013A & Pump Pit & \#23 & 348 & $\mathrm{U}$ & & HCJ-006-09 \\
\hline bis-(2-Chloroethyl)ether & E04808006013A & Tank Vault & $\# 8$ & 366 & $\mathrm{U}$ & & HCJ-006-09 \\
\hline bis-(2-Chloroethyl)ether & E04808007013A & Tank Vault & $\# 9$ & 362 & $\mathrm{U}$ & & HCJ-006-09 \\
\hline bis-(2-Chloroethyl)ether & E04808008013A & Tank Vault & $\# 15$ & 355 & $\mathrm{U}$ & & HCJ-006-09 \\
\hline bis-(2-Chloroethyl)ether & E04808009013A & Tank Vault & \#24 & 367 & $\mathrm{U}$ & & HCJ-006-09 \\
\hline bis-(2-Chloroethyl)ether & E04808010013A & Tank Vault & \#32 & 357 & $\mathrm{U}$ & & HCJ-006-09 \\
\hline bis(2-Chloroisopropyl)ether & E04808001013A & Pump Pit & $\# 3$ & 353 & $\mathrm{U}$ & & HCJ-006-09 \\
\hline bis(2-Chloroisopropyl)ether & E04808002013A & Pump Pit & $\# 12$ & 357 & $\mathrm{U}$ & & HCJ-006-09 \\
\hline bis(2-Chloroisopropyl)ether & E04808003013A & Pump Pit & $\# 16$ & 366 & $\mathrm{U}$ & & HCJ-006-09 \\
\hline bis(2-Chloroisopropyl)ether & E04808004013A & Pump Pit & $\# 18$ & 352 & $\mathrm{U}$ & & HCJ-006-09 \\
\hline bis(2-Chloroisopropyl)ether & E04808005013A & Pump Pit & \#23 & 348 & $\mathrm{U}$ & & HCJ-006-09 \\
\hline bis(2-Chloroisopropyl)ether & E04808006013A & Tank Vault & $\# 8$ & 366 & $\mathrm{U}$ & & HCJ-006-09 \\
\hline bis(2-Chloroisopropyl)ether & E04808007013A & Tank Vault & $\# 9$ & 362 & $\mathrm{U}$ & & HCJ-006-09 \\
\hline bis(2-Chloroisopropyl)ether & E04808008013A & Tank Vault & $\# 15$ & 355 & $\mathrm{U}$ & & HCJ-006-09 \\
\hline bis(2-Chloroisopropyl)ether & E04808009013A & Tank Vault & $\# 24$ & 367 & $\mathrm{U}$ & & HCJ-006-09 \\
\hline bis(2-Chloroisopropyl)ether & E04808010013A & Tank Vault & \#32 & 357 & $\mathrm{U}$ & & HCJ-006-09 \\
\hline bis-(2-ethylhexyl)phthalate & E04808001013A & Pump Pit & $\# 3$ & 176 & $\mathrm{U}$ & & HCJ-006-09 \\
\hline bis-(2-ethylhexyl)phthalate & E04808002013A & Pump Pit & $\# 12$ & 179 & $\mathrm{U}$ & & HCJ-006-09 \\
\hline bis-(2-ethylhexyl)phthalate & E04808003013A & Pump Pit & $\# 16$ & 183 & $\mathrm{U}$ & & HCJ-006-09 \\
\hline bis-(2-ethylhexyl)phthalate & E04808004013A & Pump Pit & $\# 18$ & 176 & $\mathrm{U}$ & & HCJ-006-09 \\
\hline bis-(2-ethylhexyl)phthalate & E04808005013A & Pump Pit & \#23 & 174 & $\mathrm{U}$ & & HCJ-006-09 \\
\hline bis-(2-ethylhexyl)phthalate & E04808006013A & Tank Vault & $\# 8$ & 183 & $\mathrm{U}$ & & HCJ-006-09 \\
\hline bis-(2-ethylhexyl)phthalate & E04808007013A & Tank Vault & $\# 9$ & 181 & $\mathrm{U}$ & & HCJ-006-09 \\
\hline bis-(2-ethylhexyl)phthalate & E04808008013A & Tank Vault & $\# 15$ & 178 & $\mathrm{U}$ & & HCJ-006-09 \\
\hline
\end{tabular}


Table G-4. (continued).

\begin{tabular}{|c|c|c|c|c|c|c|c|}
\hline Compound & $\begin{array}{c}\text { Field Sample } \\
\text { Number }\end{array}$ & Location & Grid & $\begin{array}{c}\text { Sample } \\
\text { Result } \\
(\mu \mathrm{g} / \mathrm{kg})\end{array}$ & $\begin{array}{l}\text { Result } \\
\text { Qual. }\end{array}$ & $\begin{array}{l}\text { Val. } \\
\text { Flag }\end{array}$ & $\begin{array}{c}\text { L\&V Report } \\
\text { Number }\end{array}$ \\
\hline bis-(2-ethylhexyl)phthalate & E04808009013A & Tank Vault & $\# 24$ & 183 & $\mathrm{U}$ & & HCJ-006-09 \\
\hline bis-(2-ethylhexyl)phthalate & E04808010013A & Tank Vault & \#32 & 178 & $\mathrm{U}$ & & HCJ-006-09 \\
\hline Butyl benzyl phthalate & E04808001013A & Pump Pit & $\# 3$ & 353 & $\mathrm{U}$ & & HCJ-006-09 \\
\hline Butyl benzyl phthalate & E04808002013A & Pump Pit & \#12 & 357 & $\mathrm{U}$ & & HCJ-006-09 \\
\hline Butyl benzyl phthalate & E04808003013A & Pump Pit & $\# 16$ & 366 & $\mathrm{U}$ & & HCJ-006-09 \\
\hline Butyl benzyl phthalate & E04808004013A & Pump Pit & $\# 18$ & 352 & $\mathrm{U}$ & & HCJ-006-09 \\
\hline Butyl benzyl phthalate & E04808005013A & Pump Pit & \#23 & 348 & $\mathrm{U}$ & & HCJ-006-09 \\
\hline Butyl benzyl phthalate & E04808006013A & Tank Vault & $\# 8$ & 366 & $\mathrm{U}$ & & HCJ-006-09 \\
\hline Butyl benzyl phthalate & E04808007013A & Tank Vault & $\# 9$ & 362 & $\mathrm{U}$ & & HCJ-006-09 \\
\hline Butyl benzyl phthalate & E04808008013A & Tank Vault & \#15 & 355 & $\mathrm{U}$ & & HCJ-006-09 \\
\hline Butyl benzyl phthalate & E04808009013A & Tank Vault & \#24 & 367 & $\mathrm{U}$ & & HCJ-006-09 \\
\hline Butyl benzyl phthalate & E04808010013A & Tank Vault & \#32 & 357 & $\mathrm{U}$ & & HCJ-006-09 \\
\hline Chrysene & E04808001013A & Pump Pit & $\# 3$ & 35 & $\mathrm{U}$ & & HCJ-006-09 \\
\hline Chrysene & E04808002013A & Pump Pit & $\# 12$ & 36 & $\mathrm{U}$ & & HCJ-006-09 \\
\hline Chrysene & E04808003013A & Pump Pit & \#16 & 37 & $\mathrm{U}$ & & HCJ-006-09 \\
\hline Chrysene & E04808004013A & Pump Pit & $\# 18$ & 35 & $\mathrm{U}$ & & HCJ-006-09 \\
\hline Chrysene & E04808005013A & Pump Pit & \#23 & 35 & $\mathrm{U}$ & & HCJ-006-09 \\
\hline Chrysene & E04808006013A & Tank Vault & $\# 8$ & 37 & $\mathrm{U}$ & & HCJ-006-09 \\
\hline Chrysene & E04808007013A & Tank Vault & $\# 9$ & 36 & $\mathrm{U}$ & & HCJ-006-09 \\
\hline Chrysene & E04808008013A & Tank Vault & $\# 15$ & 36 & $\mathrm{U}$ & & HCJ-006-09 \\
\hline Chrysene & E04808009013A & Tank Vault & \#24 & 37 & $\mathrm{U}$ & & HCJ-006-09 \\
\hline Chrysene & E04808010013A & Tank Vault & \#32 & 36 & $\mathrm{U}$ & & HCJ-006-09 \\
\hline Dibenzo(a,h)anthracene & E04808001013A & Pump Pit & $\# 3$ & 35 & $\mathrm{U}$ & & HCJ-006-09 \\
\hline Dibenzo(a,h)anthracene & E04808002013A & Pump Pit & $\# 12$ & 36 & $\mathrm{U}$ & & HCJ-006-09 \\
\hline Dibenzo(a,h)anthracene & E04808003013A & Pump Pit & $\# 16$ & 37 & $\mathrm{U}$ & & HCJ-006-09 \\
\hline Dibenzo(a,h)anthracene & E04808004013A & Pump Pit & $\# 18$ & 35 & $\mathrm{U}$ & & HCJ-006-09 \\
\hline Dibenzo(a,h)anthracene & E04808005013A & Pump Pit & \#23 & 35 & $\mathrm{U}$ & & HCJ-006-09 \\
\hline Dibenzo(a,h)anthracene & E04808006013A & Tank Vault & $\# 8$ & 37 & $\mathrm{U}$ & & HCJ-006-09 \\
\hline Dibenzo(a,h)anthracene & E04808007013A & Tank Vault & $\# 9$ & 36 & $\mathrm{U}$ & & HCJ-006-09 \\
\hline Dibenzo(a,h)anthracene & E04808008013A & Tank Vault & $\# 15$ & 36 & $\mathrm{U}$ & & HCJ-006-09 \\
\hline Dibenzo(a,h)anthracene & E04808009013A & Tank Vault & \#24 & 37 & $\mathrm{U}$ & & HCJ-006-09 \\
\hline Dibenzo(a,h)anthracene & E04808010013A & Tank Vault & \#32 & 36 & $\mathrm{U}$ & & HCJ-006-09 \\
\hline Diethyl Phthalate & E04808001013A & Pump Pit & $\# 3$ & 353 & $\mathrm{U}$ & & HCJ-006-09 \\
\hline Diethyl Phthalate & E04808002013A & Pump Pit & $\# 12$ & 357 & $\mathrm{U}$ & & HCJ-006-09 \\
\hline Diethyl Phthalate & E04808003013A & Pump Pit & $\# 16$ & 366 & $\mathrm{U}$ & & HCJ-006-09 \\
\hline Diethyl Phthalate & E04808004013A & Pump Pit & $\# 18$ & 352 & $\mathrm{U}$ & & HCJ-006-09 \\
\hline Diethyl Phthalate & E04808005013A & Pump Pit & $\# 23$ & 348 & $\mathrm{U}$ & & HCJ-006-09 \\
\hline Diethyl Phthalate & E04808006013A & Tank Vault & $\# 8$ & 366 & $\mathrm{U}$ & & HCJ-006-09 \\
\hline Diethyl Phthalate & E04808007013A & Tank Vault & $\# 9$ & 362 & $\mathrm{U}$ & & HCJ-006-09 \\
\hline Diethyl Phthalate & E04808008013A & Tank Vault & $\# 15$ & 355 & $\mathrm{U}$ & & HCJ-006-09 \\
\hline Diethyl Phthalate & E04808009013A & Tank Vault & $\# 24$ & 367 & $\mathrm{U}$ & & HCJ-006-09 \\
\hline Diethyl Phthalate & E04808010013A & Tank Vault & \#32 & 357 & $\mathrm{U}$ & & HCJ-006-09 \\
\hline Dimethoate & E04808001013A & Pump Pit & $\# 3$ & 353 & $\mathrm{U}$ & & HCJ-006-09 \\
\hline Dimethoate & E04808002013A & Pump Pit & $\# 12$ & 357 & $\mathrm{U}$ & & HCJ-006-09 \\
\hline Dimethoate & E04808003013A & Pump Pit & $\# 16$ & 366 & $\mathrm{U}$ & & HCJ-006-09 \\
\hline Dimethoate & E04808004013A & Pump Pit & $\# 18$ & 352 & $\mathrm{U}$ & & HCJ-006-09 \\
\hline Dimethoate & E04808005013A & Pump Pit & \#23 & 348 & $\mathrm{U}$ & & HCJ-006-09 \\
\hline Dimethoate & E04808006013A & Tank Vault & $\# 8$ & 366 & $\mathrm{U}$ & & HCJ-006-09 \\
\hline Dimethoate & E04808007013A & Tank Vault & $\# 9$ & 362 & $\mathrm{U}$ & & HCJ-006-09 \\
\hline
\end{tabular}


Table G-4. (continued).

\begin{tabular}{|c|c|c|c|c|c|c|c|}
\hline Compound & $\begin{array}{l}\text { Field Sample } \\
\text { Number }\end{array}$ & Location & Grid & $\begin{array}{l}\text { Sample } \\
\text { Result } \\
(\mu \mathrm{g} / \mathrm{kg})\end{array}$ & $\begin{array}{l}\text { Result } \\
\text { Qual. }\end{array}$ & $\begin{array}{l}\text { Val. } \\
\text { Flag }\end{array}$ & $\begin{array}{l}\text { L\&V Report } \\
\text { Number }\end{array}$ \\
\hline Dimethoate & E04808008013A & Tank Vault & $\# 15$ & 355 & $\mathrm{U}$ & & HCJ-006-09 \\
\hline Dimethoate & E04808009013A & Tank Vault & \#24 & 367 & $\mathrm{U}$ & & HCJ-006-09 \\
\hline Dimethoate & E04808010013A & Tank Vault & \#32 & 357 & $\mathrm{U}$ & & HCJ-006-09 \\
\hline Dimethyl phthalate & E04808001013A & Pump Pit & $\# 3$ & 353 & $\mathrm{U}$ & & HCJ-006-09 \\
\hline Dimethyl phthalate & E04808002013A & Pump Pit & \#12 & 357 & $\mathrm{U}$ & & HCJ-006-09 \\
\hline Dimethyl phthalate & E04808003013A & Pump Pit & $\# 16$ & 366 & $\mathrm{U}$ & & HCJ-006-09 \\
\hline Dimethyl phthalate & E04808004013A & Pump Pit & $\# 18$ & 352 & $\mathrm{U}$ & & HCJ-006-09 \\
\hline Dimethyl phthalate & E04808005013A & Pump Pit & \#23 & 348 & $\mathrm{U}$ & & HCJ-006-09 \\
\hline Dimethyl phthalate & E04808006013A & Tank Vault & $\# 8$ & 366 & $\mathrm{U}$ & & HCJ-006-09 \\
\hline Dimethyl phthalate & E04808007013A & Tank Vault & $\# 9$ & 362 & $\mathrm{U}$ & & HCJ-006-09 \\
\hline Dimethyl phthalate & E04808008013A & Tank Vault & $\# 15$ & 355 & $\mathrm{U}$ & & HCJ-006-09 \\
\hline Dimethyl phthalate & E04808009013A & Tank Vault & \#24 & 367 & $\mathrm{U}$ & & HCJ-006-09 \\
\hline Dimethyl phthalate & E04808010013A & Tank Vault & \#32 & 357 & $\mathrm{U}$ & & HCJ-006-09 \\
\hline Di-n-butyl phthalate & E04808001013A & Pump Pit & $\# 3$ & 353 & $\mathrm{U}$ & & HCJ-006-09 \\
\hline Di-n-butyl phthalate & E04808002013A & Pump Pit & \#12 & 357 & $\mathrm{U}$ & & HCJ-006-09 \\
\hline Di-n-butyl phthalate & E04808003013A & Pump Pit & $\# 16$ & 78 & $\mathrm{~J}$ & $\mathrm{~J}$ & HCJ-006-09 \\
\hline Di-n-butyl phthalate & E04808004013A & Pump Pit & $\# 18$ & 352 & $\mathrm{U}$ & & HCJ-006-09 \\
\hline Di-n-butyl phthalate & E04808005013A & Pump Pit & \#23 & 348 & $\mathrm{U}$ & & HCJ-006-09 \\
\hline Di-n-butyl phthalate & E04808006013A & Tank Vault & $\# 8$ & 366 & $\mathrm{U}$ & & HCJ-006-09 \\
\hline Di-n-butyl phthalate & E04808007013A & Tank Vault & $\# 9$ & 282 & $\mathrm{~J}$ & $\mathrm{~J}$ & HCJ-006-09 \\
\hline Di-n-butyl phthalate & E04808008013A & Tank Vault & $\# 15$ & 355 & $\mathrm{U}$ & & HCJ-006-09 \\
\hline Di-n-butyl phthalate & E04808009013A & Tank Vault & \#24 & 84 & $\mathrm{~J}$ & $\mathrm{~J}$ & HCJ-006-09 \\
\hline Di-n-butyl phthalate & E04808010013A & Tank Vault & \#32 & 357 & $\mathrm{U}$ & & HCJ-006-09 \\
\hline Di-n-octyl phthalate & E04808001013A & Pump Pit & $\# 3$ & 353 & $\mathrm{U}$ & & HCJ-006-09 \\
\hline Di-n-octyl phthalate & E04808002013A & Pump Pit & $\# 12$ & 357 & $\mathrm{U}$ & & HCJ-006-09 \\
\hline Di-n-octyl phthalate & E04808003013A & Pump Pit & $\# 16$ & 366 & $\mathrm{U}$ & & HCJ-006-09 \\
\hline Di-n-octyl phthalate & E04808004013A & Pump Pit & \#18 & 352 & $\mathrm{U}$ & & HCJ-006-09 \\
\hline Di-n-octyl phthalate & E04808005013A & Pump Pit & \#23 & 348 & $\mathrm{U}$ & & HCJ-006-09 \\
\hline Di-n-octyl phthalate & E04808006013A & Tank Vault & $\# 8$ & 366 & $\mathrm{U}$ & & HCJ-006-09 \\
\hline Di-n-octyl phthalate & E04808007013A & Tank Vault & $\# 9$ & 362 & $\mathrm{U}$ & & HCJ-006-09 \\
\hline Di-n-octyl phthalate & E04808008013A & Tank Vault & $\# 15$ & 355 & $\mathrm{U}$ & & HCJ-006-09 \\
\hline Di-n-octyl phthalate & E04808009013A & Tank Vault & \#24 & 367 & $\mathrm{U}$ & & HCJ-006-09 \\
\hline Di-n-octyl phthalate & E04808010013A & Tank Vault & \#32 & 357 & $\mathrm{U}$ & & HCJ-006-09 \\
\hline Dinoseb & E04808001013A & Pump Pit & $\# 3$ & 353 & $\mathrm{U}$ & & HCJ-006-09 \\
\hline Dinoseb & E04808002013A & Pump Pit & $\# 12$ & 357 & $\mathrm{U}$ & & HCJ-006-09 \\
\hline Dinoseb & E04808003013A & Pump Pit & $\# 16$ & 366 & $\mathrm{U}$ & & HCJ-006-09 \\
\hline Dinoseb & E04808004013A & Pump Pit & $\# 18$ & 352 & $\mathrm{U}$ & & HCJ-006-09 \\
\hline Dinoseb & E04808005013A & Pump Pit & \#23 & 348 & $\mathrm{U}$ & & HCJ-006-09 \\
\hline Dinoseb & E04808006013A & Tank Vault & $\# 8$ & 366 & $\mathrm{U}$ & & HCJ-006-09 \\
\hline Dinoseb & E04808007013A & Tank Vault & $\# 9$ & 362 & $\mathrm{U}$ & & HCJ-006-09 \\
\hline Dinoseb & E04808008013A & Tank Vault & $\# 15$ & 355 & $\mathrm{U}$ & & HCJ-006-09 \\
\hline Dinoseb & E04808009013A & Tank Vault & \#24 & 367 & $\mathrm{U}$ & & HCJ-006-09 \\
\hline Dinoseb & E04808010013A & Tank Vault & \#32 & 357 & $\mathrm{U}$ & & HCJ-006-09 \\
\hline Diphenylamine & E04808001013A & Pump Pit & $\# 3$ & 353 & $\mathrm{U}$ & & HCJ-006-09 \\
\hline Diphenylamine & E04808002013A & Pump Pit & $\# 12$ & 357 & $\mathrm{U}$ & & HCJ-006-09 \\
\hline Diphenylamine & E04808003013A & Pump Pit & $\# 16$ & 366 & $\mathrm{U}$ & & HCJ-006-09 \\
\hline Diphenylamine & E04808004013A & Pump Pit & $\# 18$ & 352 & $\mathrm{U}$ & & HCJ-006-09 \\
\hline Diphenylamine & E04808005013A & Pump Pit & \#23 & 348 & $\mathrm{U}$ & & HCJ-006-09 \\
\hline Diphenylamine & E04808006013A & Tank Vault & $\# 8$ & 366 & $\mathrm{U}$ & & HCJ-006-09 \\
\hline
\end{tabular}


Table G-4. (continued).

\begin{tabular}{|c|c|c|c|c|c|c|c|}
\hline Compound & $\begin{array}{c}\text { Field Sample } \\
\text { Number }\end{array}$ & Location & Grid & $\begin{array}{c}\text { Sample } \\
\text { Result } \\
(\mu \mathrm{g} / \mathrm{kg})\end{array}$ & $\begin{array}{l}\text { Result } \\
\text { Qual. }\end{array}$ & $\begin{array}{l}\text { Val. } \\
\text { Flag }\end{array}$ & $\begin{array}{c}\text { L\&V Report } \\
\text { Number }\end{array}$ \\
\hline Diphenylamine & E04808007013A & Tank Vault & \#9 & 362 & $\mathrm{U}$ & & HCJ-006-09 \\
\hline Diphenylamine & E04808008013A & Tank Vault & $\# 15$ & 355 & $\mathrm{U}$ & & HCJ-006-09 \\
\hline Diphenylamine & E04808009013A & Tank Vault & $\# 24$ & 367 & $\mathrm{U}$ & & HCJ-006-09 \\
\hline Diphenylamine & E04808010013A & Tank Vault & \#32 & 357 & $\mathrm{U}$ & & HCJ-006-09 \\
\hline Ethyl methanesulfonate & E04808001013A & Pump Pit & $\# 3$ & 353 & $\mathrm{U}$ & & HCJ-006-09 \\
\hline Ethyl methanesulfonate & E04808002013A & Pump Pit & $\# 12$ & 357 & $\mathrm{U}$ & & HCJ-006-09 \\
\hline Ethyl methanesulfonate & E04808003013A & Pump Pit & $\# 16$ & 366 & $\mathrm{U}$ & & HCJ-006-09 \\
\hline Ethyl methanesulfonate & E04808004013A & Pump Pit & $\# 18$ & 352 & $\mathrm{U}$ & & HCJ-006-09 \\
\hline Ethyl methanesulfonate & E04808005013A & Pump Pit & \#23 & 348 & $\mathrm{U}$ & & HCJ-006-09 \\
\hline Ethyl methanesulfonate & E04808006013A & Tank Vault & $\# 8$ & 366 & $\mathrm{U}$ & & HCJ-006-09 \\
\hline Ethyl methanesulfonate & E04808007013A & Tank Vault & $\# 9$ & 362 & $\mathrm{U}$ & & HCJ-006-09 \\
\hline Ethyl methanesulfonate & E04808008013A & Tank Vault & $\# 15$ & 355 & $\mathrm{U}$ & & HCJ-006-09 \\
\hline Ethyl methanesulfonate & E04808009013A & Tank Vault & $\# 24$ & 367 & $\mathrm{U}$ & & HCJ-006-09 \\
\hline Ethyl methanesulfonate & E04808010013A & Tank Vault & \#32 & 357 & $\mathrm{U}$ & & HCJ-006-09 \\
\hline Famphur & E04808001013A & Pump Pit & $\# 3$ & 353 & $\mathrm{U}$ & & HCJ-006-09 \\
\hline Famphur & E04808002013A & Pump Pit & $\# 12$ & 357 & $\mathrm{U}$ & & HCJ-006-09 \\
\hline Famphur & E04808003013A & Pump Pit & $\# 16$ & 366 & $\mathrm{U}$ & & HCJ-006-09 \\
\hline Famphur & E04808004013A & Pump Pit & $\# 18$ & 352 & $\mathrm{U}$ & & HCJ-006-09 \\
\hline Famphur & E04808005013A & Pump Pit & \#23 & 348 & $\mathrm{U}$ & & HCJ-006-09 \\
\hline Famphur & E04808006013A & Tank Vault & $\# 8$ & 366 & $\mathrm{U}$ & & HCJ-006-09 \\
\hline Famphur & E04808007013A & Tank Vault & $\# 9$ & 362 & $\mathrm{U}$ & & HCJ-006-09 \\
\hline Famphur & E04808008013A & Tank Vault & $\# 15$ & 355 & $\mathrm{U}$ & & HCJ-006-09 \\
\hline Famphur & E04808009013A & Tank Vault & $\# 24$ & 367 & $\mathrm{U}$ & & HCJ-006-09 \\
\hline Famphur & E04808010013A & Tank Vault & \#32 & 357 & $\mathrm{U}$ & & HCJ-006-09 \\
\hline Fluoranthene & E04808001013A & Pump Pit & $\# 3$ & 35 & $\mathrm{U}$ & & HCJ-006-09 \\
\hline Fluoranthene & E04808002013A & Pump Pit & $\# 12$ & 36 & $\mathrm{U}$ & & HCJ-006-09 \\
\hline Fluoranthene & E04808003013A & Pump Pit & $\# 16$ & 37 & $\mathrm{U}$ & & HCJ-006-09 \\
\hline Fluoranthene & E04808004013A & Pump Pit & $\# 18$ & 35 & $\mathrm{U}$ & & HCJ-006-09 \\
\hline Fluoranthene & E04808005013A & Pump Pit & \#23 & 35 & $\mathrm{U}$ & & HCJ-006-09 \\
\hline Fluoranthene & E04808006013A & Tank Vault & $\# 8$ & 37 & $\mathrm{U}$ & & HCJ-006-09 \\
\hline Fluoranthene & E04808007013A & Tank Vault & $\# 9$ & 36 & $\mathrm{U}$ & & HCJ-006-09 \\
\hline Fluoranthene & E04808008013A & Tank Vault & $\# 15$ & 36 & $\mathrm{U}$ & & HCJ-006-09 \\
\hline Fluoranthene & E04808009013A & Tank Vault & \#24 & 37 & $\mathrm{U}$ & & HCJ-006-09 \\
\hline Fluoranthene & E04808010013A & Tank Vault & \#32 & 36 & $\mathrm{U}$ & & HCJ-006-09 \\
\hline Fluorene & E04808001013A & Pump Pit & $\# 3$ & 35 & $\mathrm{U}$ & & HCJ-006-09 \\
\hline Fluorene & E04808002013A & Pump Pit & $\# 12$ & 36 & $\mathrm{U}$ & & HCJ-006-09 \\
\hline Fluorene & E04808003013A & Pump Pit & $\# 16$ & 37 & $\mathrm{U}$ & & HCJ-006-09 \\
\hline Fluorene & E04808004013A & Pump Pit & $\# 18$ & 35 & $\mathrm{U}$ & & HCJ-006-09 \\
\hline Fluorene & E04808005013A & Pump Pit & \#23 & 35 & $\mathrm{U}$ & & HCJ-006-09 \\
\hline Fluorene & E04808006013A & Tank Vault & $\# 8$ & 37 & $\mathrm{U}$ & & HCJ-006-09 \\
\hline Fluorene & E04808007013A & Tank Vault & $\# 9$ & 36 & $\mathrm{U}$ & & HCJ-006-09 \\
\hline Fluorene & E04808008013A & Tank Vault & $\# 15$ & 36 & $\mathrm{U}$ & & HCJ-006-09 \\
\hline Fluorene & E04808009013A & Tank Vault & \#24 & 37 & $\mathrm{U}$ & & HCJ-006-09 \\
\hline Fluorene & E04808010013A & Tank Vault & \#32 & 36 & $\mathrm{U}$ & & HCJ-006-09 \\
\hline Hexachlorobenzene & E04808001013A & Pump Pit & $\# 3$ & 353 & $\mathrm{U}$ & & HCJ-006-09 \\
\hline Hexachlorobenzene & E04808002013A & Pump Pit & $\# 12$ & 357 & $\mathrm{U}$ & & HCJ-006-09 \\
\hline Hexachlorobenzene & E04808003013A & Pump Pit & $\# 16$ & 366 & $\mathrm{U}$ & & HCJ-006-09 \\
\hline Hexachlorobenzene & E04808004013A & Pump Pit & $\# 18$ & 352 & $\mathrm{U}$ & & HCJ-006-09 \\
\hline Hexachlorobenzene & E04808005013A & Pump Pit & \#23 & 348 & $\mathrm{U}$ & & HCJ-006-09 \\
\hline
\end{tabular}


Table G-4. (continued).

\begin{tabular}{|c|c|c|c|c|c|c|c|}
\hline Compound & $\begin{array}{l}\text { Field Sample } \\
\text { Number }\end{array}$ & Location & Grid & $\begin{array}{l}\text { Sample } \\
\text { Result } \\
(\mu \mathrm{g} / \mathrm{kg})\end{array}$ & $\begin{array}{l}\text { Result } \\
\text { Qual. }\end{array}$ & $\begin{array}{l}\text { Val. } \\
\text { Flag }\end{array}$ & $\begin{array}{l}\text { L\&V Report } \\
\text { Number }\end{array}$ \\
\hline Hexachlorobenzene & E04808006013A & Tank Vault & $\# 8$ & 366 & $\mathrm{U}$ & & HCJ-006-09 \\
\hline Hexachlorobenzene & E04808007013A & Tank Vault & $\# 9$ & 362 & $\mathrm{U}$ & & HCJ-006-09 \\
\hline Hexachlorobenzene & E04808008013A & Tank Vault & $\# 15$ & 355 & $\mathrm{U}$ & & HCJ-006-09 \\
\hline Hexachlorobenzene & E04808009013A & Tank Vault & $\# 24$ & 367 & $\mathrm{U}$ & & HCJ-006-09 \\
\hline Hexachlorobenzene & E04808010013A & Tank Vault & \#32 & 357 & $\mathrm{U}$ & & HCJ-006-09 \\
\hline Hexachlorobutadiene & E04808001013A & Pump Pit & $\# 3$ & 353 & $\mathrm{U}$ & & HCJ-006-09 \\
\hline Hexachlorobutadiene & E04808002013A & Pump Pit & $\# 12$ & 357 & $\mathrm{U}$ & & HCJ-006-09 \\
\hline Hexachlorobutadiene & E04808003013A & Pump Pit & $\# 16$ & 366 & $\mathrm{U}$ & & HCJ-006-09 \\
\hline Hexachlorobutadiene & E04808004013A & Pump Pit & $\# 18$ & 352 & $\mathrm{U}$ & & HCJ-006-09 \\
\hline Hexachlorobutadiene & E04808005013A & Pump Pit & \#23 & 348 & $\mathrm{U}$ & & HCJ-006-09 \\
\hline Hexachlorobutadiene & E04808006013A & Tank Vault & $\# 8$ & 366 & $\mathrm{U}$ & & HCJ-006-09 \\
\hline Hexachlorobutadiene & E04808007013A & Tank Vault & $\# 9$ & 362 & $\mathrm{U}$ & & HCJ-006-09 \\
\hline Hexachlorobutadiene & E04808008013A & Tank Vault & $\# 15$ & 355 & $\mathrm{U}$ & & HCJ-006-09 \\
\hline Hexachlorobutadiene & E04808009013A & Tank Vault & \#24 & 367 & $\mathrm{U}$ & & HCJ-006-09 \\
\hline Hexachlorobutadiene & E04808010013A & Tank Vault & \#32 & 357 & $\mathrm{U}$ & & HCJ-006-09 \\
\hline Hexachlorocyclopentadiene & E04808001013A & Pump Pit & $\# 3$ & 353 & $\mathrm{U}$ & & HCJ-006-09 \\
\hline Hexachlorocyclopentadiene & E04808002013A & Pump Pit & $\# 12$ & 357 & $\mathrm{U}$ & & HCJ-006-09 \\
\hline Hexachlorocyclopentadiene & E04808003013A & Pump Pit & \#16 & 366 & $\mathrm{U}$ & & HCJ-006-09 \\
\hline Hexachlorocyclopentadiene & E04808004013A & Pump Pit & $\# 18$ & 352 & $\mathrm{U}$ & & HCJ-006-09 \\
\hline Hexachlorocyclopentadiene & E04808005013A & Pump Pit & \#23 & 348 & $\mathrm{U}$ & & HCJ-006-09 \\
\hline Hexachlorocyclopentadiene & E04808006013A & Tank Vault & $\# 8$ & 366 & $\mathrm{U}$ & & HCJ-006-09 \\
\hline Hexachlorocyclopentadiene & E04808007013A & Tank Vault & $\# 9$ & 362 & $\mathrm{U}$ & & HCJ-006-09 \\
\hline Hexachlorocyclopentadiene & E04808008013A & Tank Vault & $\# 15$ & 355 & $\mathrm{U}$ & & HCJ-006-09 \\
\hline Hexachlorocyclopentadiene & E04808009013A & Tank Vault & \#24 & 367 & $\mathrm{U}$ & & HCJ-006-09 \\
\hline Hexachlorocyclopentadiene & E04808010013A & Tank Vault & \#32 & 357 & $\mathrm{U}$ & & HCJ-006-09 \\
\hline Hexachloroethane & E04808001013A & Pump Pit & $\# 3$ & 353 & $\mathrm{U}$ & & HCJ-006-09 \\
\hline Hexachloroethane & E04808002013A & Pump Pit & $\# 12$ & 357 & $\mathrm{U}$ & & HCJ-006-09 \\
\hline Hexachloroethane & E04808003013A & Pump Pit & $\# 16$ & 366 & $\mathrm{U}$ & & HCJ-006-09 \\
\hline Hexachloroethane & E04808004013A & Pump Pit & $\# 18$ & 352 & $\mathrm{U}$ & & HCJ-006-09 \\
\hline Hexachloroethane & E04808005013A & Pump Pit & \#23 & 348 & $\mathrm{U}$ & & HCJ-006-09 \\
\hline Hexachloroethane & E04808006013A & Tank Vault & $\# 8$ & 366 & $\mathrm{U}$ & & HCJ-006-09 \\
\hline Hexachloroethane & E04808007013A & Tank Vault & $\# 9$ & 362 & $\mathrm{U}$ & & HCJ-006-09 \\
\hline Hexachloroethane & E04808008013A & Tank Vault & $\# 15$ & 355 & $\mathrm{U}$ & & HCJ-006-09 \\
\hline Hexachloroethane & E04808009013A & Tank Vault & \#24 & 367 & $\mathrm{U}$ & & HCJ-006-09 \\
\hline Hexachloroethane & E04808010013A & Tank Vault & \#32 & 357 & $\mathrm{U}$ & & HCJ-006-09 \\
\hline Hexachlorophene & E04808001013A & Pump Pit & $\# 3$ & 17600 & $\mathrm{U}$ & $\mathrm{R}$ & HCJ-006-09 \\
\hline Hexachlorophene & E04808002013A & Pump Pit & $\# 12$ & 17900 & $\mathrm{U}$ & $\mathrm{R}$ & HCJ-006-09 \\
\hline Hexachlorophene & E04808003013A & Pump Pit & $\# 16$ & 18300 & $\mathrm{U}$ & $\mathrm{R}$ & HCJ-006-09 \\
\hline Hexachlorophene & E04808004013A & Pump Pit & $\# 18$ & 17600 & $\mathrm{U}$ & $\mathrm{R}$ & HCJ-006-09 \\
\hline Hexachlorophene & E04808005013A & Pump Pit & \#23 & 17400 & $\mathrm{U}$ & $\mathrm{R}$ & HCJ-006-09 \\
\hline Hexachlorophene & E04808006013A & Tank Vault & $\# 8$ & 18300 & $\mathrm{U}$ & $\mathrm{R}$ & HCJ-006-09 \\
\hline Hexachlorophene & E04808007013A & Tank Vault & $\# 9$ & 18100 & $\mathrm{U}$ & $\mathrm{R}$ & HCJ-006-09 \\
\hline Hexachlorophene & E04808008013A & Tank Vault & $\# 15$ & 17800 & $\mathrm{U}$ & $\mathrm{R}$ & HCJ-006-09 \\
\hline Hexachlorophene & E04808009013A & Tank Vault & \#24 & 18300 & $\mathrm{U}$ & $\mathrm{R}$ & HCJ-006-09 \\
\hline Hexachlorophene & E04808010013A & Tank Vault & \#32 & 17800 & $\mathrm{U}$ & $\mathrm{R}$ & HCJ-006-09 \\
\hline Hexachloropropene & E04808001013A & Pump Pit & $\# 3$ & 353 & $\mathrm{U}$ & & HCJ-006-09 \\
\hline Hexachloropropene & E04808002013A & Pump Pit & $\# 12$ & 357 & $\mathrm{U}$ & & HCJ-006-09 \\
\hline Hexachloropropene & E04808003013A & Pump Pit & $\# 16$ & 366 & $\mathrm{U}$ & & HCJ-006-09 \\
\hline Hexachloropropene & E04808004013A & Pump Pit & \#18 & 352 & $\mathrm{U}$ & & HCJ-006-09 \\
\hline
\end{tabular}


Table G-4. (continued).

\begin{tabular}{|c|c|c|c|c|c|c|c|}
\hline Compound & $\begin{array}{c}\text { Field Sample } \\
\text { Number }\end{array}$ & Location & Grid & $\begin{array}{c}\text { Sample } \\
\text { Result } \\
(\mu \mathrm{g} / \mathrm{kg})\end{array}$ & $\begin{array}{l}\text { Result } \\
\text { Qual. }\end{array}$ & $\begin{array}{l}\text { Val. } \\
\text { Flag }\end{array}$ & $\begin{array}{c}\text { L\&V Report } \\
\text { Number }\end{array}$ \\
\hline Hexachloropropene & E04808005013A & Pump Pit & $\# 23$ & 348 & $\mathrm{U}$ & & HCJ-006-09 \\
\hline Hexachloropropene & E04808006013A & Tank Vault & $\# 8$ & 366 & $\mathrm{U}$ & & HCJ-006-09 \\
\hline Hexachloropropene & E04808007013A & Tank Vault & $\# 9$ & 362 & $\mathrm{U}$ & & HCJ-006-09 \\
\hline Hexachloropropene & E04808008013A & Tank Vault & $\# 15$ & 355 & $\mathrm{U}$ & & HCJ-006-09 \\
\hline Hexachloropropene & E04808009013A & Tank Vault & \#24 & 367 & $\mathrm{U}$ & & HCJ-006-09 \\
\hline Hexachloropropene & E04808010013A & Tank Vault & \#32 & 357 & $\mathrm{U}$ & & HCJ-006-09 \\
\hline Indeno(1,2,3-cd)pyrene & E04808001013A & Pump Pit & \#3 & 35 & $\mathrm{U}$ & & HCJ-006-09 \\
\hline Indeno(1,2,3-cd)pyrene & E04808002013A & Pump Pit & $\# 12$ & 36 & $\mathrm{U}$ & & HCJ-006-09 \\
\hline Indeno(1,2,3-cd)pyrene & E04808003013A & Pump Pit & $\# 16$ & 37 & $\mathrm{U}$ & & HCJ-006-09 \\
\hline Indeno(1,2,3-cd)pyrene & E04808004013A & Pump Pit & \#18 & 35 & $\mathrm{U}$ & & HCJ-006-09 \\
\hline Indeno(1,2,3-cd)pyrene & E04808005013A & Pump Pit & \#23 & 35 & $\mathrm{U}$ & & HCJ-006-09 \\
\hline Indeno(1,2,3-cd)pyrene & E04808006013A & Tank Vault & $\# 8$ & 37 & $\mathrm{U}$ & & HCJ-006-09 \\
\hline Indeno(1,2,3-cd)pyrene & E04808007013A & Tank Vault & $\# 9$ & 36 & $\mathrm{U}$ & & HCJ-006-09 \\
\hline Indeno(1,2,3-cd)pyrene & E04808008013A & Tank Vault & $\# 15$ & 36 & $\mathrm{U}$ & & HCJ-006-09 \\
\hline Indeno(1,2,3-cd)pyrene & E04808009013A & Tank Vault & \#24 & 37 & $\mathrm{U}$ & & HCJ-006-09 \\
\hline Indeno(1,2,3-cd)pyrene & E04808010013A & Tank Vault & \#32 & 36 & $\mathrm{U}$ & & HCJ-006-09 \\
\hline Isophorone & E04808001013A & Pump Pit & $\# 3$ & 353 & $\mathrm{U}$ & & HCJ-006-09 \\
\hline Isophorone & E04808002013A & Pump Pit & $\# 12$ & 357 & $\mathrm{U}$ & & HCJ-006-09 \\
\hline Isophorone & E04808003013A & Pump Pit & $\# 16$ & 366 & $\mathrm{U}$ & & HCJ-006-09 \\
\hline Isophorone & E04808004013A & Pump Pit & $\# 18$ & 352 & $\mathrm{U}$ & & HCJ-006-09 \\
\hline Isophorone & E04808005013A & Pump Pit & \#23 & 348 & $\mathrm{U}$ & & HCJ-006-09 \\
\hline Isophorone & E04808006013A & Tank Vault & \#8 & 366 & $\mathrm{U}$ & & HCJ-006-09 \\
\hline Isophorone & E04808007013A & Tank Vault & $\# 9$ & 362 & $\mathrm{U}$ & & HCJ-006-09 \\
\hline Isophorone & E04808008013A & Tank Vault & \#15 & 355 & $\mathrm{U}$ & & HCJ-006-09 \\
\hline Isophorone & E04808009013A & Tank Vault & \#24 & 367 & $\mathrm{U}$ & & HCJ-006-09 \\
\hline Isophorone & E04808010013A & Tank Vault & \#32 & 357 & $\mathrm{U}$ & & HCJ-006-09 \\
\hline Isosafrole & E04808001013A & Pump Pit & \#3 & 353 & $\mathrm{U}$ & & HCJ-006-09 \\
\hline Isosafrole & E04808002013A & Pump Pit & \#12 & 357 & $\mathrm{U}$ & & HCJ-006-09 \\
\hline Isosafrole & E04808003013A & Pump Pit & $\# 16$ & 366 & $\mathrm{U}$ & & HCJ-006-09 \\
\hline Isosafrole & E04808004013A & Pump Pit & $\# 18$ & 352 & $\mathrm{U}$ & & HCJ-006-09 \\
\hline Isosafrole & E04808005013A & Pump Pit & \#23 & 348 & $\mathrm{U}$ & & HCJ-006-09 \\
\hline Isosafrole & E04808006013A & Tank Vault & $\# 8$ & 366 & $\mathrm{U}$ & & HCJ-006-09 \\
\hline Isosafrole & E04808007013A & Tank Vault & $\# 9$ & 362 & $\mathrm{U}$ & & HCJ-006-09 \\
\hline Isosafrole & E04808008013A & Tank Vault & $\# 15$ & 355 & $\mathrm{U}$ & & HCJ-006-09 \\
\hline Isosafrole & E04808009013A & Tank Vault & \#24 & 367 & $\mathrm{U}$ & & HCJ-006-09 \\
\hline Isosafrole & E04808010013A & Tank Vault & \#32 & 357 & $\mathrm{U}$ & & HCJ-006-09 \\
\hline m,p-Cresols & E04808001013A & Pump Pit & $\# 3$ & 353 & $\mathrm{U}$ & & HCJ-006-09 \\
\hline m,p-Cresols & E04808002013A & Pump Pit & \#12 & 357 & $\mathrm{U}$ & & HCJ-006-09 \\
\hline m,p-Cresols & E04808003013A & Pump Pit & $\# 16$ & 366 & $\mathrm{U}$ & & HCJ-006-09 \\
\hline m,p-Cresols & E04808004013A & Pump Pit & $\# 18$ & 352 & $\mathrm{U}$ & & HCJ-006-09 \\
\hline $\mathrm{m}, \mathrm{p}$-Cresols & E04808005013A & Pump Pit & \#23 & 348 & $\mathrm{U}$ & & HCJ-006-09 \\
\hline m,p-Cresols & E04808006013A & Tank Vault & $\# 8$ & 366 & $\mathrm{U}$ & & HCJ-006-09 \\
\hline m,p-Cresols & E04808007013A & Tank Vault & $\# 9$ & 362 & $\mathrm{U}$ & & HCJ-006-09 \\
\hline m,p-Cresols & E04808008013A & Tank Vault & \#15 & 355 & $\mathrm{U}$ & & HCJ-006-09 \\
\hline m,p-Cresols & E04808009013A & Tank Vault & \#24 & 367 & $\mathrm{U}$ & & HCJ-006-09 \\
\hline m,p-Cresols & E04808010013A & Tank Vault & \#32 & 357 & $\mathrm{U}$ & & HCJ-006-09 \\
\hline m-Dinitrobenzene & E04808001013A & Pump Pit & $\# 3$ & 353 & $\mathrm{U}$ & & HCJ-006-09 \\
\hline m-Dinitrobenzene & E04808002013A & Pump Pit & $\# 12$ & 357 & $\mathrm{U}$ & & HCJ-006-09 \\
\hline m-Dinitrobenzene & E04808003013A & Pump Pit & $\# 16$ & 366 & $\mathrm{U}$ & & HCJ-006-09 \\
\hline
\end{tabular}


Table G-4. (continued).

\begin{tabular}{|c|c|c|c|c|c|c|c|}
\hline Compound & $\begin{array}{l}\text { Field Sample } \\
\text { Number }\end{array}$ & Location & Grid & $\begin{array}{l}\text { Sample } \\
\text { Result } \\
(\mu \mathrm{g} / \mathrm{kg})\end{array}$ & $\begin{array}{l}\text { Result } \\
\text { Qual. }\end{array}$ & $\begin{array}{l}\text { Val. } \\
\text { Flag }\end{array}$ & $\begin{array}{l}\text { L\&V Report } \\
\text { Number }\end{array}$ \\
\hline m-Dinitrobenzene & E04808004013A & Pump Pit & $\# 18$ & 352 & $\mathrm{U}$ & & HCJ-006-09 \\
\hline m-Dinitrobenzene & E04808005013A & Pump Pit & \#23 & 348 & $\mathrm{U}$ & & HCJ-006-09 \\
\hline m-Dinitrobenzene & E04808006013A & Tank Vault & $\# 8$ & 366 & $\mathrm{U}$ & & HCJ-006-09 \\
\hline m-Dinitrobenzene & E04808007013A & Tank Vault & $\# 9$ & 362 & $\mathrm{U}$ & & HCJ-006-09 \\
\hline m-Dinitrobenzene & E04808008013A & Tank Vault & $\# 15$ & 355 & $\mathrm{U}$ & & HCJ-006-09 \\
\hline m-Dinitrobenzene & E04808009013A & Tank Vault & $\# 24$ & 367 & $\mathrm{U}$ & & HCJ-006-09 \\
\hline m-Dinitrobenzene & E04808010013A & Tank Vault & \#32 & 357 & $\mathrm{U}$ & & HCJ-006-09 \\
\hline Methapyrilene & E04808001013A & Pump Pit & \#3 & 353 & $\mathrm{U}$ & & HCJ-006-09 \\
\hline Methapyrilene & E04808002013A & Pump Pit & $\# 12$ & 357 & $\mathrm{U}$ & & HCJ-006-09 \\
\hline Methapyrilene & E04808003013A & Pump Pit & $\# 16$ & 366 & $\mathrm{U}$ & & HCJ-006-09 \\
\hline Methapyrilene & E04808004013A & Pump Pit & $\# 18$ & 352 & $\mathrm{U}$ & & HCJ-006-09 \\
\hline Methapyrilene & E04808005013A & Pump Pit & \#23 & 348 & $\mathrm{U}$ & & HCJ-006-09 \\
\hline Methapyrilene & E04808006013A & Tank Vault & $\# 8$ & 366 & $\mathrm{U}$ & & HCJ-006-09 \\
\hline Methapyrilene & E04808007013A & Tank Vault & $\# 9$ & 362 & $\mathrm{U}$ & & HCJ-006-09 \\
\hline Methapyrilene & E04808008013A & Tank Vault & $\# 15$ & 355 & $\mathrm{U}$ & & HCJ-006-09 \\
\hline Methapyrilene & E04808009013A & Tank Vault & $\# 24$ & 367 & $\mathrm{U}$ & & HCJ-006-09 \\
\hline Methapyrilene & E04808010013A & Tank Vault & \#32 & 357 & $\mathrm{U}$ & & HCJ-006-09 \\
\hline Methyl methanesulfonate & E04808001013A & Pump Pit & $\# 3$ & 353 & $\mathrm{U}$ & & HCJ-006-09 \\
\hline Methyl methanesulfonate & E04808002013A & Pump Pit & $\# 12$ & 357 & $\mathrm{U}$ & & HCJ-006-09 \\
\hline Methyl methanesulfonate & E04808003013A & Pump Pit & $\# 16$ & 366 & $\mathrm{U}$ & & HCJ-006-09 \\
\hline Methyl methanesulfonate & E04808004013A & Pump Pit & $\# 18$ & 352 & $\mathrm{U}$ & & HCJ-006-09 \\
\hline Methyl methanesulfonate & E04808005013A & Pump Pit & \#23 & 348 & $\mathrm{U}$ & & HCJ-006-09 \\
\hline Methyl methanesulfonate & E04808006013A & Tank Vault & $\# 8$ & 366 & $\mathrm{U}$ & & HCJ-006-09 \\
\hline Methyl methanesulfonate & E04808007013A & Tank Vault & $\# 9$ & 362 & $\mathrm{U}$ & & HCJ-006-09 \\
\hline Methyl methanesulfonate & E04808008013A & Tank Vault & $\# 15$ & 355 & $\mathrm{U}$ & & HCJ-006-09 \\
\hline Methyl methanesulfonate & E04808009013A & Tank Vault & $\# 24$ & 367 & $\mathrm{U}$ & & HCJ-006-09 \\
\hline Methyl methanesulfonate & E04808010013A & Tank Vault & \#32 & 357 & $\mathrm{U}$ & & HCJ-006-09 \\
\hline m-Nitroaniline & E04808001013A & Pump Pit & $\# 3$ & 353 & $\mathrm{U}$ & & HCJ-006-09 \\
\hline m-Nitroaniline & E04808002013A & Pump Pit & $\# 12$ & 357 & $\mathrm{U}$ & & HCJ-006-09 \\
\hline m-Nitroaniline & E04808003013A & Pump Pit & $\# 16$ & 366 & $\mathrm{U}$ & & HCJ-006-09 \\
\hline m-Nitroaniline & E04808004013A & Pump Pit & $\# 18$ & 352 & $\mathrm{U}$ & & HCJ-006-09 \\
\hline m-Nitroaniline & E04808005013A & Pump Pit & \#23 & 348 & $\mathrm{U}$ & & HCJ-006-09 \\
\hline m-Nitroaniline & E04808006013A & Tank Vault & $\# 8$ & 366 & $\mathrm{U}$ & & HCJ-006-09 \\
\hline m-Nitroaniline & E04808007013A & Tank Vault & $\# 9$ & 362 & $\mathrm{U}$ & & HCJ-006-09 \\
\hline m-Nitroaniline & E04808008013A & Tank Vault & $\# 15$ & 355 & $\mathrm{U}$ & & HCJ-006-09 \\
\hline m-Nitroaniline & E04808009013A & Tank Vault & $\# 24$ & 367 & $\mathrm{U}$ & & HCJ-006-09 \\
\hline m-Nitroaniline & E04808010013A & Tank Vault & \#32 & 357 & $\mathrm{U}$ & & HCJ-006-09 \\
\hline Naphthalene & E04808001013A & Pump Pit & $\# 3$ & 35 & $\mathrm{U}$ & & HCJ-006-09 \\
\hline Naphthalene & E04808002013A & Pump Pit & $\# 12$ & 36 & $\mathrm{U}$ & & HCJ-006-09 \\
\hline Naphthalene & E04808003013A & Pump Pit & $\# 16$ & 37 & $\mathrm{U}$ & & HCJ-006-09 \\
\hline Naphthalene & E04808004013A & Pump Pit & $\# 18$ & 35 & $\mathrm{U}$ & & HCJ-006-09 \\
\hline Naphthalene & E04808005013A & Pump Pit & \#23 & 35 & $\mathrm{U}$ & & HCJ-006-09 \\
\hline Naphthalene & E04808006013A & Tank Vault & $\# 8$ & 37 & $\mathrm{U}$ & & HCJ-006-09 \\
\hline Naphthalene & E04808007013A & Tank Vault & $\# 9$ & 36 & $\mathrm{U}$ & & HCJ-006-09 \\
\hline Naphthalene & E04808008013A & Tank Vault & $\# 15$ & 36 & $\mathrm{U}$ & & HCJ-006-09 \\
\hline Naphthalene & E04808009013A & Tank Vault & \#24 & 37 & $\mathrm{U}$ & & HCJ-006-09 \\
\hline Naphthalene & E04808010013A & Tank Vault & \#32 & 36 & $\mathrm{U}$ & & HCJ-006-09 \\
\hline Nitrobenzene & E04808001013A & Pump Pit & $\# 3$ & 353 & $\mathrm{U}$ & & HCJ-006-09 \\
\hline Nitrobenzene & E04808002013A & Pump Pit & \#12 & 357 & $\mathrm{U}$ & & HCJ-006-09 \\
\hline
\end{tabular}


Table G-4. (continued).

\begin{tabular}{|c|c|c|c|c|c|c|c|}
\hline Compound & $\begin{array}{l}\text { Field Sample } \\
\text { Number }\end{array}$ & Location & Grid & $\begin{array}{l}\text { Sample } \\
\text { Result } \\
(\mu \mathrm{g} / \mathrm{kg})\end{array}$ & $\begin{array}{l}\text { Result } \\
\text { Qual. }\end{array}$ & $\begin{array}{l}\text { Val. } \\
\text { Flag }\end{array}$ & $\begin{array}{l}\text { L\&V Report } \\
\text { Number }\end{array}$ \\
\hline Nitrobenzene & E04808003013A & Pump Pit & $\# 16$ & 366 & $\mathrm{U}$ & & HCJ-006-09 \\
\hline Nitrobenzene & E04808004013A & Pump Pit & $\# 18$ & 352 & $\mathrm{U}$ & & HCJ-006-09 \\
\hline Nitrobenzene & E04808005013A & Pump Pit & \#23 & 348 & $\mathrm{U}$ & & HCJ-006-09 \\
\hline Nitrobenzene & E04808006013A & Tank Vault & $\# 8$ & 366 & $\mathrm{U}$ & & HCJ-006-09 \\
\hline Nitrobenzene & E04808007013A & Tank Vault & $\# 9$ & 362 & $\mathrm{U}$ & & HCJ-006-09 \\
\hline Nitrobenzene & E04808008013A & Tank Vault & $\# 15$ & 355 & $\mathrm{U}$ & & HCJ-006-09 \\
\hline Nitrobenzene & E04808009013A & Tank Vault & \#24 & 367 & $\mathrm{U}$ & & HCJ-006-09 \\
\hline Nitrobenzene & E04808010013A & Tank Vault & \#32 & 357 & $\mathrm{U}$ & & HCJ-006-09 \\
\hline n-methyl-n-nitrosomethylamine & E04808001013A & Pump Pit & $\# 3$ & 353 & $\mathrm{U}$ & & HCJ-006-09 \\
\hline n-methyl-n-nitrosomethylamine & E04808002013A & Pump Pit & $\# 12$ & 357 & $\mathrm{U}$ & & HCJ-006-09 \\
\hline n-methyl-n-nitrosomethylamine & E04808003013A & Pump Pit & $\# 16$ & 366 & $\mathrm{U}$ & & HCJ-006-09 \\
\hline n-methyl-n-nitrosomethylamine & E04808004013A & Pump Pit & $\# 18$ & 352 & $\mathrm{U}$ & & HCJ-006-09 \\
\hline n-methyl-n-nitrosomethylamine & E04808005013A & Pump Pit & \#23 & 348 & $\mathrm{U}$ & & HCJ-006-09 \\
\hline n-methyl-n-nitrosomethylamine & E04808006013A & Tank Vault & \#8 & 366 & $\mathrm{U}$ & & HCJ-006-09 \\
\hline n-methyl-n-nitrosomethylamine & E04808007013A & Tank Vault & $\# 9$ & 362 & $\mathrm{U}$ & & HCJ-006-09 \\
\hline n-methyl-n-nitrosomethylamine & E04808008013A & Tank Vault & $\# 15$ & 355 & $\mathrm{U}$ & & HCJ-006-09 \\
\hline n-methyl-n-nitrosomethylamine & E04808009013A & Tank Vault & \#24 & 367 & $\mathrm{U}$ & & HCJ-006-09 \\
\hline n-methyl-n-nitrosomethylamine & E04808010013A & Tank Vault & \#32 & 357 & $\mathrm{U}$ & & HCJ-006-09 \\
\hline n-Nitrosodiethylamine & E04808001013A & Pump Pit & $\# 3$ & 353 & $\mathrm{U}$ & & HCJ-006-09 \\
\hline n-Nitrosodiethylamine & E04808002013A & Pump Pit & $\# 12$ & 357 & $\mathrm{U}$ & & HCJ-006-09 \\
\hline n-Nitrosodiethylamine & E04808003013A & Pump Pit & \#16 & 366 & $\mathrm{U}$ & & HCJ-006-09 \\
\hline n-Nitrosodiethylamine & E04808004013A & Pump Pit & \#18 & 352 & $\mathrm{U}$ & & HCJ-006-09 \\
\hline n-Nitrosodiethylamine & E04808005013A & Pump Pit & \#23 & 348 & $\mathrm{U}$ & & HCJ-006-09 \\
\hline n-Nitrosodiethylamine & E04808006013A & Tank Vault & $\# 8$ & 366 & $\mathrm{U}$ & & HCJ-006-09 \\
\hline n-Nitrosodiethylamine & E04808007013A & Tank Vault & $\# 9$ & 362 & $\mathrm{U}$ & & HCJ-006-09 \\
\hline n-Nitrosodiethylamine & E04808008013A & Tank Vault & $\# 15$ & 355 & $\mathrm{U}$ & & HCJ-006-09 \\
\hline n-Nitrosodiethylamine & E04808009013A & Tank Vault & \#24 & 367 & $\mathrm{U}$ & & HCJ-006-09 \\
\hline n-Nitrosodiethylamine & E04808010013A & Tank Vault & \#32 & 357 & $\mathrm{U}$ & & HCJ-006-09 \\
\hline n-Nitroso-di-n-butylamine & E04808001013A & Pump Pit & $\# 3$ & 353 & $\mathrm{U}$ & & HCJ-006-09 \\
\hline n-Nitroso-di-n-butylamine & E04808002013A & Pump Pit & $\# 12$ & 357 & $\mathrm{U}$ & & HCJ-006-09 \\
\hline n-Nitroso-di-n-butylamine & E04808003013A & Pump Pit & $\# 16$ & 366 & $\mathrm{U}$ & & HCJ-006-09 \\
\hline n-Nitroso-di-n-butylamine & E04808004013A & Pump Pit & \#18 & 352 & $\mathrm{U}$ & & HCJ-006-09 \\
\hline n-Nitroso-di-n-butylamine & E04808005013A & Pump Pit & \#23 & 348 & $\mathrm{U}$ & & HCJ-006-09 \\
\hline n-Nitroso-di-n-butylamine & E04808006013A & Tank Vault & $\# 8$ & 366 & $\mathrm{U}$ & & HCJ-006-09 \\
\hline n-Nitroso-di-n-butylamine & E04808007013A & Tank Vault & $\# 9$ & 362 & $\mathrm{U}$ & & HCJ-006-09 \\
\hline n-Nitroso-di-n-butylamine & E04808008013A & Tank Vault & $\# 15$ & 355 & $\mathrm{U}$ & & HCJ-006-09 \\
\hline n-Nitroso-di-n-butylamine & E04808009013A & Tank Vault & \#24 & 367 & $\mathrm{U}$ & & HCJ-006-09 \\
\hline n-Nitroso-di-n-butylamine & E04808010013A & Tank Vault & \#32 & 357 & $\mathrm{U}$ & & HCJ-006-09 \\
\hline N-Nitrosodipropylamine & E04808001013A & Pump Pit & $\# 3$ & 353 & $\mathrm{U}$ & & HCJ-006-09 \\
\hline N-Nitrosodipropylamine & E04808002013A & Pump Pit & $\# 12$ & 357 & $\mathrm{U}$ & & HCJ-006-09 \\
\hline N-Nitrosodipropylamine & E04808003013A & Pump Pit & $\# 16$ & 366 & $\mathrm{U}$ & & HCJ-006-09 \\
\hline N-Nitrosodipropylamine & E04808004013A & Pump Pit & $\# 18$ & 352 & $\mathrm{U}$ & & HCJ-006-09 \\
\hline N-Nitrosodipropylamine & E04808005013A & Pump Pit & \#23 & 348 & $\mathrm{U}$ & & HCJ-006-09 \\
\hline N-Nitrosodipropylamine & E04808006013A & Tank Vault & $\# 8$ & 366 & $\mathrm{U}$ & & HCJ-006-09 \\
\hline N-Nitrosodipropylamine & E04808007013A & Tank Vault & $\# 9$ & 362 & $\mathrm{U}$ & & HCJ-006-09 \\
\hline N-Nitrosodipropylamine & E04808008013A & Tank Vault & $\# 15$ & 355 & $\mathrm{U}$ & & HCJ-006-09 \\
\hline N-Nitrosodipropylamine & E04808009013A & Tank Vault & \#24 & 367 & $\mathrm{U}$ & & HCJ-006-09 \\
\hline N-Nitrosodipropylamine & E04808010013A & Tank Vault & \#32 & 357 & $\mathrm{U}$ & & HCJ-006-09 \\
\hline n-Nitrosomethylethylamine & E04808001013A & Pump Pit & $\# 3$ & 353 & $\mathrm{U}$ & & HCJ-006-09 \\
\hline
\end{tabular}


Table G-4. (continued).

\begin{tabular}{|c|c|c|c|c|c|c|c|}
\hline Compound & $\begin{array}{l}\text { Field Sample } \\
\text { Number }\end{array}$ & Location & Grid & $\begin{array}{l}\text { Sample } \\
\text { Result } \\
(\mu \mathrm{g} / \mathrm{kg})\end{array}$ & $\begin{array}{l}\text { Result } \\
\text { Qual. }\end{array}$ & $\begin{array}{l}\text { Val. } \\
\text { Flag }\end{array}$ & $\begin{array}{l}\text { L\&V Report } \\
\text { Number }\end{array}$ \\
\hline n-Nitrosomethylethylamine & E04808002013A & Pump Pit & $\# 12$ & 357 & $\mathrm{U}$ & & HCJ-006-09 \\
\hline n-Nitrosomethylethylamine & E04808003013A & Pump Pit & $\# 16$ & 366 & $\mathrm{U}$ & & HCJ-006-09 \\
\hline n-Nitrosomethylethylamine & E04808004013A & Pump Pit & $\# 18$ & 352 & $\mathrm{U}$ & & HCJ-006-09 \\
\hline n-Nitrosomethylethylamine & E04808005013A & Pump Pit & \#23 & 348 & $\mathrm{U}$ & & HCJ-006-09 \\
\hline n-Nitrosomethylethylamine & E04808006013A & Tank Vault & $\# 8$ & 366 & $\mathrm{U}$ & & HCJ-006-09 \\
\hline n-Nitrosomethylethylamine & E04808007013A & Tank Vault & $\# 9$ & 362 & $\mathrm{U}$ & & HCJ-006-09 \\
\hline n-Nitrosomethylethylamine & E04808008013A & Tank Vault & $\# 15$ & 355 & $\mathrm{U}$ & & HCJ-006-09 \\
\hline n-Nitrosomethylethylamine & E04808009013A & Tank Vault & \#24 & 367 & $\mathrm{U}$ & & HCJ-006-09 \\
\hline n-Nitrosomethylethylamine & E04808010013A & Tank Vault & \#32 & 357 & $\mathrm{U}$ & & HCJ-006-09 \\
\hline n-Nitrosomorpholine & E04808001013A & Pump Pit & $\# 3$ & 353 & $\mathrm{U}$ & & HCJ-006-09 \\
\hline n-Nitrosomorpholine & E04808002013A & Pump Pit & $\# 12$ & 357 & $\mathrm{U}$ & & HCJ-006-09 \\
\hline n-Nitrosomorpholine & E04808003013A & Pump Pit & $\# 16$ & 366 & $\mathrm{U}$ & & HCJ-006-09 \\
\hline n-Nitrosomorpholine & E04808004013A & Pump Pit & $\# 18$ & 352 & $\mathrm{U}$ & & HCJ-006-09 \\
\hline n-Nitrosomorpholine & E04808005013A & Pump Pit & \#23 & 348 & $\mathrm{U}$ & & HCJ-006-09 \\
\hline n-Nitrosomorpholine & E04808006013A & Tank Vault & \#8 & 366 & $\mathrm{U}$ & & HCJ-006-09 \\
\hline n-Nitrosomorpholine & E04808007013A & Tank Vault & $\# 9$ & 362 & $\mathrm{U}$ & & HCJ-006-09 \\
\hline n-Nitrosomorpholine & E04808008013A & Tank Vault & $\# 15$ & 355 & $\mathrm{U}$ & & HCJ-006-09 \\
\hline n-Nitrosomorpholine & E04808009013A & Tank Vault & \#24 & 367 & $\mathrm{U}$ & & HCJ-006-09 \\
\hline n-Nitrosomorpholine & E04808010013A & Tank Vault & \#32 & 357 & $\mathrm{U}$ & & HCJ-006-09 \\
\hline n-Nitrosopiperidine & E04808001013A & Pump Pit & $\# 3$ & 353 & $\mathrm{U}$ & & HCJ-006-09 \\
\hline n-Nitrosopiperidine & E04808002013A & Pump Pit & $\# 12$ & 357 & $\mathrm{U}$ & & HCJ-006-09 \\
\hline n-Nitrosopiperidine & E04808003013A & Pump Pit & $\# 16$ & 366 & $\mathrm{U}$ & & HCJ-006-09 \\
\hline n-Nitrosopiperidine & E04808004013A & Pump Pit & $\# 18$ & 352 & $\mathrm{U}$ & & HCJ-006-09 \\
\hline n-Nitrosopiperidine & E04808005013A & Pump Pit & \#23 & 348 & $\mathrm{U}$ & & HCJ-006-09 \\
\hline n-Nitrosopiperidine & E04808006013A & Tank Vault & $\# 8$ & 366 & $\mathrm{U}$ & & HCJ-006-09 \\
\hline n-Nitrosopiperidine & E04808007013A & Tank Vault & $\# 9$ & 362 & $\mathrm{U}$ & & HCJ-006-09 \\
\hline n-Nitrosopiperidine & E04808008013A & Tank Vault & $\# 15$ & 355 & $\mathrm{U}$ & & HCJ-006-09 \\
\hline n-Nitrosopiperidine & E04808009013A & Tank Vault & \#24 & 367 & $\mathrm{U}$ & & HCJ-006-09 \\
\hline n-Nitrosopiperidine & E04808010013A & Tank Vault & \#32 & 357 & $\mathrm{U}$ & & HCJ-006-09 \\
\hline n-Nitrosopyrrolidine & E04808001013A & Pump Pit & $\# 3$ & 353 & $\mathrm{U}$ & & HCJ-006-09 \\
\hline n-Nitrosopyrrolidine & E04808002013A & Pump Pit & \#12 & 357 & $\mathrm{U}$ & & HCJ-006-09 \\
\hline n-Nitrosopyrrolidine & E04808003013A & Pump Pit & $\# 16$ & 366 & $\mathrm{U}$ & & HCJ-006-09 \\
\hline n-Nitrosopyrrolidine & E04808004013A & Pump Pit & $\# 18$ & 352 & $\mathrm{U}$ & & HCJ-006-09 \\
\hline n-Nitrosopyrrolidine & E04808005013A & Pump Pit & \#23 & 348 & $\mathrm{U}$ & & HCJ-006-09 \\
\hline n-Nitrosopyrrolidine & E04808006013A & Tank Vault & $\# 8$ & 366 & $\mathrm{U}$ & & HCJ-006-09 \\
\hline n-Nitrosopyrrolidine & E04808007013A & Tank Vault & $\# 9$ & 362 & $\mathrm{U}$ & & HCJ-006-09 \\
\hline n-Nitrosopyrrolidine & E04808008013A & Tank Vault & $\# 15$ & 355 & $\mathrm{U}$ & & HCJ-006-09 \\
\hline n-Nitrosopyrrolidine & E04808009013A & Tank Vault & \#24 & 367 & $\mathrm{U}$ & & HCJ-006-09 \\
\hline n-Nitrosopyrrolidine & E04808010013A & Tank Vault & \#32 & 357 & $\mathrm{U}$ & & HCJ-006-09 \\
\hline o-Cresol & E04808001013A & Pump Pit & $\# 3$ & 353 & $\mathrm{U}$ & & HCJ-006-09 \\
\hline o-Cresol & E04808002013A & Pump Pit & $\# 12$ & 357 & $\mathrm{U}$ & & HCJ-006-09 \\
\hline o-Cresol & E04808003013A & Pump Pit & $\# 16$ & 366 & $\mathrm{U}$ & & HCJ-006-09 \\
\hline o-Cresol & E04808004013A & Pump Pit & $\# 18$ & 352 & $\mathrm{U}$ & & HCJ-006-09 \\
\hline o-Cresol & E04808005013A & Pump Pit & \#23 & 348 & $\mathrm{U}$ & & HCJ-006-09 \\
\hline o-Cresol & E04808006013A & Tank Vault & $\# 8$ & 366 & $\mathrm{U}$ & & HCJ-006-09 \\
\hline o-Cresol & E04808007013A & Tank Vault & $\# 9$ & 362 & $\mathrm{U}$ & & HCJ-006-09 \\
\hline o-Cresol & E04808008013A & Tank Vault & $\# 15$ & 355 & $\mathrm{U}$ & & HCJ-006-09 \\
\hline o-Cresol & E04808009013A & Tank Vault & $\# 24$ & 367 & $\mathrm{U}$ & & HCJ-006-09 \\
\hline o-Cresol & E04808010013A & Tank Vault & \#32 & 357 & $\mathrm{U}$ & & HCJ-006-09 \\
\hline
\end{tabular}


Table G-4. (continued).

\begin{tabular}{|c|c|c|c|c|c|c|c|}
\hline Compound & $\begin{array}{l}\text { Field Sample } \\
\text { Number }\end{array}$ & Location & Grid & $\begin{array}{l}\text { Sample } \\
\text { Result } \\
(\mu \mathrm{g} / \mathrm{kg})\end{array}$ & $\begin{array}{l}\text { Result } \\
\text { Qual. }\end{array}$ & $\begin{array}{l}\text { Val. } \\
\text { Flag }\end{array}$ & $\begin{array}{l}\text { L\&V Report } \\
\text { Number }\end{array}$ \\
\hline o-Nitroaniline & E04808001013A & Pump Pit & $\# 3$ & 353 & $\mathrm{U}$ & & HCJ-006-09 \\
\hline o-Nitroaniline & E04808002013A & Pump Pit & $\# 12$ & 357 & $\mathrm{U}$ & & HCJ-006-09 \\
\hline o-Nitroaniline & E04808003013A & Pump Pit & $\# 16$ & 366 & $\mathrm{U}$ & & HCJ-006-09 \\
\hline o-Nitroaniline & E04808004013A & Pump Pit & $\# 18$ & 352 & $\mathrm{U}$ & & HCJ-006-09 \\
\hline o-Nitroaniline & E04808005013A & Pump Pit & \#23 & 348 & $\mathrm{U}$ & & HCJ-006-09 \\
\hline o-Nitroaniline & E04808006013A & Tank Vault & $\# 8$ & 366 & $\mathrm{U}$ & & HCJ-006-09 \\
\hline o-Nitroaniline & E04808007013A & Tank Vault & $\# 9$ & 362 & $\mathrm{U}$ & & HCJ-006-09 \\
\hline o-Nitroaniline & E04808008013A & Tank Vault & $\# 15$ & 355 & $\mathrm{U}$ & & HCJ-006-09 \\
\hline o-Nitroaniline & E04808009013A & Tank Vault & \#24 & 367 & $\mathrm{U}$ & & HCJ-006-09 \\
\hline o-Nitroaniline & E04808010013A & Tank Vault & \#32 & 357 & $\mathrm{U}$ & & HCJ-006-09 \\
\hline o-Toluidine & E04808001013A & Pump Pit & $\# 3$ & 353 & $\mathrm{U}$ & & HCJ-006-09 \\
\hline o-Toluidine & E04808002013A & Pump Pit & $\# 12$ & 357 & $\mathrm{U}$ & & HCJ-006-09 \\
\hline o-Toluidine & E04808003013A & Pump Pit & $\# 16$ & 366 & $\mathrm{U}$ & & HCJ-006-09 \\
\hline o-Toluidine & E04808004013A & Pump Pit & $\# 18$ & 352 & $\mathrm{U}$ & & HCJ-006-09 \\
\hline o-Toluidine & E04808005013A & Pump Pit & \#23 & 348 & $\mathrm{U}$ & & HCJ-006-09 \\
\hline o-Toluidine & E04808006013A & Tank Vault & $\# 8$ & 366 & $\mathrm{U}$ & & HCJ-006-09 \\
\hline o-Toluidine & E04808007013A & Tank Vault & $\# 9$ & 362 & $\mathrm{U}$ & & HCJ-006-09 \\
\hline o-Toluidine & E04808008013A & Tank Vault & $\# 15$ & 355 & $\mathrm{U}$ & & HCJ-006-09 \\
\hline o-Toluidine & E04808009013A & Tank Vault & \#24 & 367 & $\mathrm{U}$ & & HCJ-006-09 \\
\hline o-Toluidine & E04808010013A & Tank Vault & \#32 & 357 & $\mathrm{U}$ & & HCJ-006-09 \\
\hline p-Dimethylaminoazobenzene & E04808001013A & Pump Pit & $\# 3$ & 353 & $\mathrm{U}$ & & HCJ-006-09 \\
\hline p-Dimethylaminoazobenzene & E04808002013A & Pump Pit & $\# 12$ & 357 & $\mathrm{U}$ & & HCJ-006-09 \\
\hline p-Dimethylaminoazobenzene & E04808003013A & Pump Pit & $\# 16$ & 366 & $\mathrm{U}$ & & HCJ-006-09 \\
\hline p-Dimethylaminoazobenzene & E04808004013A & Pump Pit & $\# 18$ & 352 & $\mathrm{U}$ & & HCJ-006-09 \\
\hline p-Dimethylaminoazobenzene & E04808005013A & Pump Pit & \#23 & 348 & $\mathrm{U}$ & & HCJ-006-09 \\
\hline p-Dimethylaminoazobenzene & E04808006013A & Tank Vault & $\# 8$ & 366 & $\mathrm{U}$ & & HCJ-006-09 \\
\hline p-Dimethylaminoazobenzene & E04808007013A & Tank Vault & $\# 9$ & 362 & $\mathrm{U}$ & & HCJ-006-09 \\
\hline p-Dimethylaminoazobenzene & E04808008013A & Tank Vault & $\# 15$ & 355 & $\mathrm{U}$ & & HCJ-006-09 \\
\hline p-Dimethylaminoazobenzene & E04808009013A & Tank Vault & $\# 24$ & 367 & $\mathrm{U}$ & & HCJ-006-09 \\
\hline p-Dimethylaminoazobenzene & E04808010013A & Tank Vault & \#32 & 357 & $\mathrm{U}$ & & HCJ-006-09 \\
\hline Pentachlorobenzene & E04808001013A & Pump Pit & \#3 & 353 & $\mathrm{U}$ & & HCJ-006-09 \\
\hline Pentachlorobenzene & E04808002013A & Pump Pit & \#12 & 357 & $\mathrm{U}$ & & HCJ-006-09 \\
\hline Pentachlorobenzene & E04808003013A & Pump Pit & $\# 16$ & 366 & $\mathrm{U}$ & & HCJ-006-09 \\
\hline Pentachlorobenzene & E04808004013A & Pump Pit & $\# 18$ & 352 & $\mathrm{U}$ & & HCJ-006-09 \\
\hline Pentachlorobenzene & E04808005013A & Pump Pit & \#23 & 348 & $\mathrm{U}$ & & HCJ-006-09 \\
\hline Pentachlorobenzene & E04808006013A & Tank Vault & $\# 8$ & 366 & $\mathrm{U}$ & & HCJ-006-09 \\
\hline Pentachlorobenzene & E04808007013A & Tank Vault & $\# 9$ & 362 & $\mathrm{U}$ & & HCJ-006-09 \\
\hline Pentachlorobenzene & E04808008013A & Tank Vault & $\# 15$ & 355 & $\mathrm{U}$ & & HCJ-006-09 \\
\hline Pentachlorobenzene & E04808009013A & Tank Vault & $\# 24$ & 367 & $\mathrm{U}$ & & HCJ-006-09 \\
\hline Pentachlorobenzene & E04808010013A & Tank Vault & \#32 & 357 & $\mathrm{U}$ & & HCJ-006-09 \\
\hline Pentachloroethane & E04808001013A & Pump Pit & $\# 3$ & 353 & $\mathrm{U}$ & & HCJ-006-09 \\
\hline Pentachloroethane & E04808002013A & Pump Pit & $\# 12$ & 357 & $\mathrm{U}$ & & HCJ-006-09 \\
\hline Pentachloroethane & E04808003013A & Pump Pit & $\# 16$ & 366 & $\mathrm{U}$ & & HCJ-006-09 \\
\hline Pentachloroethane & E04808004013A & Pump Pit & $\# 18$ & 352 & $\mathrm{U}$ & & HCJ-006-09 \\
\hline Pentachloroethane & E04808005013A & Pump Pit & \#23 & 348 & $\mathrm{U}$ & & HCJ-006-09 \\
\hline Pentachloroethane & E04808006013A & Tank Vault & $\# 8$ & 366 & $\mathrm{U}$ & & HCJ-006-09 \\
\hline Pentachloroethane & E04808007013A & Tank Vault & $\# 9$ & 362 & $\mathrm{U}$ & & HCJ-006-09 \\
\hline Pentachloroethane & E04808008013A & Tank Vault & $\# 15$ & 355 & $\mathrm{U}$ & & HCJ-006-09 \\
\hline Pentachloroethane & E04808009013A & Tank Vault & $\# 24$ & 367 & $\mathrm{U}$ & & HCJ-006-09 \\
\hline
\end{tabular}


Table G-4. (continued).

\begin{tabular}{|c|c|c|c|c|c|c|c|}
\hline Compound & $\begin{array}{l}\text { Field Sample } \\
\text { Number }\end{array}$ & Location & Grid & $\begin{array}{l}\text { Sample } \\
\text { Result } \\
(\mu \mathrm{g} / \mathrm{kg})\end{array}$ & $\begin{array}{l}\text { Result } \\
\text { Qual. }\end{array}$ & $\begin{array}{l}\text { Val. } \\
\text { Flag }\end{array}$ & $\begin{array}{l}\text { L\&V Report } \\
\text { Number }\end{array}$ \\
\hline Pentachloroethane & E04808010013A & Tank Vault & $\# 32$ & 357 & $\mathrm{U}$ & & HCJ-006-09 \\
\hline Pentachloronitrobenzene & E04808001013A & Pump Pit & $\# 3$ & 353 & $\mathrm{U}$ & & HCJ-006-09 \\
\hline Pentachloronitrobenzene & E04808002013A & Pump Pit & $\# 12$ & 357 & $\mathrm{U}$ & & HCJ-006-09 \\
\hline Pentachloronitrobenzene & E04808003013A & Pump Pit & $\# 16$ & 366 & $\mathrm{U}$ & & HCJ-006-09 \\
\hline Pentachloronitrobenzene & E04808004013A & Pump Pit & $\# 18$ & 352 & $\mathrm{U}$ & & HCJ-006-09 \\
\hline Pentachloronitrobenzene & E04808005013A & Pump Pit & $\# 23$ & 348 & $\mathrm{U}$ & & HCJ-006-09 \\
\hline Pentachloronitrobenzene & E04808006013A & Tank Vault & $\# 8$ & 366 & $\mathrm{U}$ & & HCJ-006-09 \\
\hline Pentachloronitrobenzene & E04808007013A & Tank Vault & $\# 9$ & 362 & $\mathrm{U}$ & & HCJ-006-09 \\
\hline Pentachloronitrobenzene & E04808008013A & Tank Vault & $\# 15$ & 355 & $\mathrm{U}$ & & HCJ-006-09 \\
\hline Pentachloronitrobenzene & E04808009013A & Tank Vault & \#24 & 367 & $\mathrm{U}$ & & HCJ-006-09 \\
\hline Pentachloronitrobenzene & E04808010013A & Tank Vault & \#32 & 357 & $\mathrm{U}$ & & HCJ-006-09 \\
\hline Pentachlorophenol & E04808001013A & Pump Pit & $\# 3$ & 353 & $\mathrm{U}$ & & HCJ-006-09 \\
\hline Pentachlorophenol & E04808002013A & Pump Pit & $\# 12$ & 357 & $\mathrm{U}$ & & HCJ-006-09 \\
\hline Pentachlorophenol & E04808003013A & Pump Pit & $\# 16$ & 366 & $\mathrm{U}$ & & HCJ-006-09 \\
\hline Pentachlorophenol & E04808004013A & Pump Pit & $\# 18$ & 352 & $\mathrm{U}$ & & HCJ-006-09 \\
\hline Pentachlorophenol & E04808005013A & Pump Pit & \#23 & 348 & $\mathrm{U}$ & & HCJ-006-09 \\
\hline Pentachlorophenol & E04808006013A & Tank Vault & $\# 8$ & 366 & $\mathrm{U}$ & & HCJ-006-09 \\
\hline Pentachlorophenol & E04808007013A & Tank Vault & $\# 9$ & 362 & $\mathrm{U}$ & & HCJ-006-09 \\
\hline Pentachlorophenol & E04808008013A & Tank Vault & $\# 15$ & 355 & $\mathrm{U}$ & & HCJ-006-09 \\
\hline Pentachlorophenol & E04808009013A & Tank Vault & \#24 & 367 & $\mathrm{U}$ & & HCJ-006-09 \\
\hline Pentachlorophenol & E04808010013A & Tank Vault & \#32 & 357 & $\mathrm{U}$ & & HCJ-006-09 \\
\hline Phenacetin & E04808001013A & Pump Pit & $\# 3$ & 353 & $\mathrm{U}$ & & HCJ-006-09 \\
\hline Phenacetin & E04808002013A & Pump Pit & $\# 12$ & 357 & $\mathrm{U}$ & & HCJ-006-09 \\
\hline Phenacetin & E04808003013A & Pump Pit & $\# 16$ & 366 & $\mathrm{U}$ & & HCJ-006-09 \\
\hline Phenacetin & E04808004013A & Pump Pit & $\# 18$ & 352 & $\mathrm{U}$ & & HCJ-006-09 \\
\hline Phenacetin & E04808005013A & Pump Pit & \#23 & 348 & $\mathrm{U}$ & & HCJ-006-09 \\
\hline Phenacetin & E04808006013A & Tank Vault & $\# 8$ & 366 & $\mathrm{U}$ & & HCJ-006-09 \\
\hline Phenacetin & E04808007013A & Tank Vault & $\# 9$ & 362 & $\mathrm{U}$ & & HCJ-006-09 \\
\hline Phenacetin & E04808008013A & Tank Vault & $\# 15$ & 355 & $\mathrm{U}$ & & HCJ-006-09 \\
\hline Phenacetin & E04808009013A & Tank Vault & $\# 24$ & 367 & $\mathrm{U}$ & & HCJ-006-09 \\
\hline Phenacetin & E04808010013A & Tank Vault & \#32 & 357 & $\mathrm{U}$ & & HCJ-006-09 \\
\hline Phenanthrene & E04808001013A & Pump Pit & $\# 3$ & 35 & $\mathrm{U}$ & & HCJ-006-09 \\
\hline Phenanthrene & E04808002013A & Pump Pit & $\# 12$ & 36 & $\mathrm{U}$ & & HCJ-006-09 \\
\hline Phenanthrene & E04808003013A & Pump Pit & $\# 16$ & 37 & $\mathrm{U}$ & & HCJ-006-09 \\
\hline Phenanthrene & E04808004013A & Pump Pit & $\# 18$ & 35 & $\mathrm{U}$ & & HCJ-006-09 \\
\hline Phenanthrene & E04808005013A & Pump Pit & \#23 & 35 & $\mathrm{U}$ & & HCJ-006-09 \\
\hline Phenanthrene & E04808006013A & Tank Vault & $\# 8$ & 37 & $\mathrm{U}$ & & HCJ-006-09 \\
\hline Phenanthrene & E04808007013A & Tank Vault & $\# 9$ & 36 & $\mathrm{U}$ & & HCJ-006-09 \\
\hline Phenanthrene & E04808008013A & Tank Vault & $\# 15$ & 36 & $\mathrm{U}$ & & HCJ-006-09 \\
\hline Phenanthrene & E04808009013A & Tank Vault & $\# 24$ & 37 & $\mathrm{U}$ & & HCJ-006-09 \\
\hline Phenanthrene & E04808010013A & Tank Vault & \#32 & 36 & $\mathrm{U}$ & & HCJ-006-09 \\
\hline Phenol & E04808001013A & Pump Pit & $\# 3$ & 353 & $\mathrm{U}$ & & HCJ-006-09 \\
\hline Phenol & E04808002013A & Pump Pit & $\# 12$ & 357 & $\mathrm{U}$ & & HCJ-006-09 \\
\hline Phenol & E04808003013A & Pump Pit & $\# 16$ & 366 & $\mathrm{U}$ & & HCJ-006-09 \\
\hline Phenol & E04808004013A & Pump Pit & $\# 18$ & 352 & $\mathrm{U}$ & & HCJ-006-09 \\
\hline Phenol & E04808005013A & Pump Pit & \#23 & 348 & $\mathrm{U}$ & & HCJ-006-09 \\
\hline Phenol & E04808006013A & Tank Vault & $\# 8$ & 366 & $\mathrm{U}$ & & HCJ-006-09 \\
\hline Phenol & E04808007013A & Tank Vault & $\# 9$ & 362 & $\mathrm{U}$ & & HCJ-006-09 \\
\hline Phenol & E04808008013A & Tank Vault & $\# 15$ & 355 & $\mathrm{U}$ & & HCJ-006-09 \\
\hline
\end{tabular}


Table G-4. (continued).

\begin{tabular}{|c|c|c|c|c|c|c|c|}
\hline Compound & $\begin{array}{l}\text { Field Sample } \\
\text { Number }\end{array}$ & Location & Grid & $\begin{array}{c}\text { Sample } \\
\text { Result } \\
(\mu \mathrm{g} / \mathrm{kg})\end{array}$ & $\begin{array}{l}\text { Result } \\
\text { Qual. }\end{array}$ & $\begin{array}{l}\text { Val. } \\
\text { Flag }\end{array}$ & $\begin{array}{l}\text { L\&V Report } \\
\text { Number }\end{array}$ \\
\hline Phenol & E04808009013A & Tank Vault & $\# 24$ & 367 & $\mathrm{U}$ & & HCJ-006-09 \\
\hline Phenol & E04808010013A & Tank Vault & \#32 & 357 & $\mathrm{U}$ & & HCJ-006-09 \\
\hline p-Nitroaniline & E04808001013A & Pump Pit & $\# 3$ & 353 & $\mathrm{U}$ & & HCJ-006-09 \\
\hline p-Nitroaniline & E04808002013A & Pump Pit & $\# 12$ & 357 & $\mathrm{U}$ & & HCJ-006-09 \\
\hline p-Nitroaniline & E04808003013A & Pump Pit & $\# 16$ & 366 & $\mathrm{U}$ & & HCJ-006-09 \\
\hline p-Nitroaniline & E04808004013A & Pump Pit & $\# 18$ & 352 & $\mathrm{U}$ & & HCJ-006-09 \\
\hline p-Nitroaniline & E04808005013A & Pump Pit & $\# 23$ & 348 & $\mathrm{U}$ & & HCJ-006-09 \\
\hline p-Nitroaniline & E04808006013A & Tank Vault & $\# 8$ & 366 & $\mathrm{U}$ & & HCJ-006-09 \\
\hline p-Nitroaniline & E04808007013A & Tank Vault & $\# 9$ & 362 & $\mathrm{U}$ & & HCJ-006-09 \\
\hline p-Nitroaniline & E04808008013A & Tank Vault & $\# 15$ & 355 & $\mathrm{U}$ & & HCJ-006-09 \\
\hline p-Nitroaniline & E04808009013A & Tank Vault & $\# 24$ & 367 & $\mathrm{U}$ & & HCJ-006-09 \\
\hline p-Nitroaniline & E04808010013A & Tank Vault & \#32 & 357 & $\mathrm{U}$ & & HCJ-006-09 \\
\hline p-Phenylenediamine & E04808001013A & Pump Pit & $\# 3$ & 353 & $\mathrm{U}$ & & HCJ-006-09 \\
\hline p-Phenylenediamine & E04808002013A & Pump Pit & $\# 12$ & 357 & $\mathrm{U}$ & & HCJ-006-09 \\
\hline p-Phenylenediamine & E04808003013A & Pump Pit & $\# 16$ & 366 & $\mathrm{U}$ & & HCJ-006-09 \\
\hline p-Phenylenediamine & E04808004013A & Pump Pit & $\# 18$ & 352 & $\mathrm{U}$ & & HCJ-006-09 \\
\hline p-Phenylenediamine & E04808005013A & Pump Pit & \#23 & 348 & $\mathrm{U}$ & & HCJ-006-09 \\
\hline p-Phenylenediamine & E04808006013A & Tank Vault & $\# 8$ & 366 & $\mathrm{U}$ & & HCJ-006-09 \\
\hline p-Phenylenediamine & E04808007013A & Tank Vault & $\# 9$ & 362 & $\mathrm{U}$ & & HCJ-006-09 \\
\hline p-Phenylenediamine & E04808008013A & Tank Vault & $\# 15$ & 355 & $\mathrm{U}$ & & HCJ-006-09 \\
\hline p-Phenylenediamine & E04808009013A & Tank Vault & $\# 24$ & 367 & $\mathrm{U}$ & & HCJ-006-09 \\
\hline p-Phenylenediamine & E04808010013A & Tank Vault & \#32 & 357 & $\mathrm{U}$ & & HCJ-006-09 \\
\hline Pronamide & E04808001013A & Pump Pit & $\# 3$ & 353 & $\mathrm{U}$ & & HCJ-006-09 \\
\hline Pronamide & E04808002013A & Pump Pit & $\# 12$ & 357 & $\mathrm{U}$ & & HCJ-006-09 \\
\hline Pronamide & E04808003013A & Pump Pit & $\# 16$ & 366 & $\mathrm{U}$ & & HCJ-006-09 \\
\hline Pronamide & E04808004013A & Pump Pit & $\# 18$ & 352 & $\mathrm{U}$ & & HCJ-006-09 \\
\hline Pronamide & E04808005013A & Pump Pit & $\# 23$ & 348 & $\mathrm{U}$ & & HCJ-006-09 \\
\hline Pronamide & E04808006013A & Tank Vault & $\# 8$ & 366 & $\mathrm{U}$ & & HCJ-006-09 \\
\hline Pronamide & E04808007013A & Tank Vault & $\# 9$ & 362 & $\mathrm{U}$ & & HCJ-006-09 \\
\hline Pronamide & E04808008013A & Tank Vault & $\# 15$ & 355 & $\mathrm{U}$ & & HCJ-006-09 \\
\hline Pronamide & E04808009013A & Tank Vault & $\# 24$ & 367 & $\mathrm{U}$ & & HCJ-006-09 \\
\hline Pronamide & E04808010013A & Tank Vault & $\# 32$ & 357 & $\mathrm{U}$ & & HCJ-006-09 \\
\hline Pyrene & E04808001013A & Pump Pit & \#3 & 35 & $\mathrm{U}$ & & HCJ-006-09 \\
\hline Pyrene & E04808002013A & Pump Pit & $\# 12$ & 36 & $\mathrm{U}$ & & HCJ-006-09 \\
\hline Pyrene & E04808003013A & Pump Pit & $\# 16$ & 37 & $\mathrm{U}$ & & HCJ-006-09 \\
\hline Pyrene & E04808004013A & Pump Pit & $\# 18$ & 35 & $\mathrm{U}$ & & HCJ-006-09 \\
\hline Pyrene & E04808005013A & Pump Pit & $\# 23$ & 35 & $\mathrm{U}$ & & HCJ-006-09 \\
\hline Pyrene & E04808006013A & Tank Vault & $\# 8$ & 37 & $\mathrm{U}$ & & HCJ-006-09 \\
\hline Pyrene & E04808007013A & Tank Vault & $\# 9$ & 36 & $\mathrm{U}$ & & HCJ-006-09 \\
\hline Pyrene & E04808008013A & Tank Vault & $\# 15$ & 36 & $\mathrm{U}$ & & HCJ-006-09 \\
\hline Pyrene & E04808009013A & Tank Vault & $\# 24$ & 37 & $\mathrm{U}$ & & HCJ-006-09 \\
\hline Pyrene & E04808010013A & Tank Vault & \#32 & 36 & $\mathrm{U}$ & & HCJ-006-09 \\
\hline Pyridine & E04808001013A & Pump Pit & $\# 3$ & 353 & $\mathrm{U}$ & & HCJ-006-09 \\
\hline Pyridine & E04808002013A & Pump Pit & $\# 12$ & 357 & $\mathrm{U}$ & & HCJ-006-09 \\
\hline Pyridine & E04808003013A & Pump Pit & $\# 16$ & 366 & $\mathrm{U}$ & & HCJ-006-09 \\
\hline Pyridine & E04808004013A & Pump Pit & $\# 18$ & 352 & $\mathrm{U}$ & & HCJ-006-09 \\
\hline Pyridine & E04808005013A & Pump Pit & $\# 23$ & 348 & $\mathrm{U}$ & & HCJ-006-09 \\
\hline Pyridine & E04808006013A & Tank Vault & $\# 8$ & 366 & $\mathrm{U}$ & & HCJ-006-09 \\
\hline Pyridine & E04808007013A & Tank Vault & $\# 9$ & 362 & $\mathrm{U}$ & & HCJ-006-09 \\
\hline
\end{tabular}


Table G-4. (continued).

\begin{tabular}{|c|c|c|c|c|c|c|c|}
\hline Compound & $\begin{array}{l}\text { Field Sample } \\
\text { Number }\end{array}$ & Location & Grid & $\begin{array}{l}\text { Sample } \\
\text { Result } \\
(\mu \mathrm{g} / \mathrm{kg})\end{array}$ & $\begin{array}{l}\text { Result } \\
\text { Qual. }\end{array}$ & $\begin{array}{l}\text { Val. } \\
\text { Flag }\end{array}$ & $\begin{array}{l}\text { L\&V Report } \\
\text { Number }\end{array}$ \\
\hline Pyridine & E04808008013A & Tank Vault & $\# 15$ & 355 & $\mathrm{U}$ & & HCJ-006-09 \\
\hline Pyridine & E04808009013A & Tank Vault & \#24 & 367 & $\mathrm{U}$ & & HCJ-006-09 \\
\hline Pyridine & E04808010013A & Tank Vault & \#32 & 357 & $\mathrm{U}$ & & HCJ-006-09 \\
\hline Safrole & E04808001013A & Pump Pit & $\# 3$ & 353 & $\mathrm{U}$ & & HCJ-006-09 \\
\hline Safrole & E04808002013A & Pump Pit & $\# 12$ & 357 & $\mathrm{U}$ & & HCJ-006-09 \\
\hline Safrole & E04808003013A & Pump Pit & $\# 16$ & 366 & $\mathrm{U}$ & & HCJ-006-09 \\
\hline Safrole & E04808004013A & Pump Pit & $\# 18$ & 352 & $\mathrm{U}$ & & HCJ-006-09 \\
\hline Safrole & E04808005013A & Pump Pit & \#23 & 348 & $\mathrm{U}$ & & HCJ-006-09 \\
\hline Safrole & E04808006013A & Tank Vault & $\# 8$ & 366 & $\mathrm{U}$ & & HCJ-006-09 \\
\hline Safrole & E04808007013A & Tank Vault & $\# 9$ & 362 & $\mathrm{U}$ & & HCJ-006-09 \\
\hline Safrole & E04808008013A & Tank Vault & $\# 15$ & 355 & $\mathrm{U}$ & & HCJ-006-09 \\
\hline Safrole & E04808009013A & Tank Vault & $\# 24$ & 367 & $\mathrm{U}$ & & HCJ-006-09 \\
\hline Safrole & E04808010013A & Tank Vault & \#32 & 357 & $\mathrm{U}$ & & HCJ-006-09 \\
\hline Triethylphosphorothioate & E04808001013A & Pump Pit & $\# 3$ & 353 & $\mathrm{U}$ & & HCJ-006-09 \\
\hline Triethylphosphorothioate & E04808002013A & Pump Pit & $\# 12$ & 357 & $\mathrm{U}$ & & HCJ-006-09 \\
\hline Triethylphosphorothioate & E04808003013A & Pump Pit & $\# 16$ & 366 & $\mathrm{U}$ & & HCJ-006-09 \\
\hline Triethylphosphorothioate & E04808004013A & Pump Pit & $\# 18$ & 352 & $\mathrm{U}$ & & HCJ-006-09 \\
\hline Triethylphosphorothioate & E04808005013A & Pump Pit & \#23 & 348 & $\mathrm{U}$ & & HCJ-006-09 \\
\hline Triethylphosphorothioate & E04808006013A & Tank Vault & $\# 8$ & 366 & $\mathrm{U}$ & & HCJ-006-09 \\
\hline Triethylphosphorothioate & E04808007013A & Tank Vault & $\# 9$ & 362 & $\mathrm{U}$ & & HCJ-006-09 \\
\hline Triethylphosphorothioate & E04808008013A & Tank Vault & $\# 15$ & 355 & $\mathrm{U}$ & & HCJ-006-09 \\
\hline Triethylphosphorothioate & E04808009013A & Tank Vault & \#24 & 367 & $\mathrm{U}$ & & HCJ-006-09 \\
\hline Triethylphosphorothioate & E04808010013A & Tank Vault & \#32 & 357 & $\mathrm{U}$ & & HCJ-006-09 \\
\hline \multicolumn{8}{|c|}{ Explanation of Result Qualifiers } \\
\hline \multicolumn{8}{|c|}{$\mathrm{U}=$ Compound was not detected at method detection limit } \\
\hline \multicolumn{8}{|c|}{ Explanation of Validation Flags } \\
\hline $\mathrm{R}=$ Data rejected for use & rious QC issues ide & till & & & & & \\
\hline
\end{tabular}


Table G-5. ESP-048-08 SFE-20 soil sample results for inorganics.

\begin{tabular}{|c|c|c|c|c|c|c|c|}
\hline Compound & $\begin{array}{c}\text { Field Sample } \\
\text { Number }\end{array}$ & Location & Grid & $\begin{array}{c}\text { Sample } \\
\text { Result } \\
(\mathrm{mg} / \mathrm{kg})\end{array}$ & $\begin{array}{l}\text { Result } \\
\text { Qual. }\end{array}$ & $\begin{array}{l}\text { Val. } \\
\text { Flag } \\
\end{array}$ & $\begin{array}{c}\text { L\&V Report } \\
\text { Number }\end{array}$ \\
\hline Antimony & E04808001013A & Pump Pit & $\# 3$ & 1.3 & B & & DNT-009-09 \\
\hline Antimony & E04808002013A & Pump Pit & $\# 12$ & 1.5 & B & & DNT-009-09 \\
\hline Antimony & E04808003013A & Pump Pit & $\# 16$ & 1.4 & B & & DNT-009-09 \\
\hline Antimony & E04808004013A & Pump Pit & $\# 18$ & 1.3 & $\mathrm{~B}$ & & DNT-009-09 \\
\hline Antimony & E04808005013A & Pump Pit & \#23 & 0.99 & B & & DNT-009-09 \\
\hline Antimony & E04808006013A & Tank Vault & $\# 8$ & 1.3 & B & & DNT-009-09 \\
\hline Antimony & E04808007013A & Tank Vault & $\# 9$ & 1.9 & B & & DNT-009-09 \\
\hline Antimony & E04808008013A & Tank Vault & $\# 15$ & 1.7 & B & & DNT-009-09 \\
\hline Antimony & E04808009013A & Tank Vault & $\# 24$ & 1.7 & B & & DNT-009-09 \\
\hline Antimony & E04808010013A & Tank Vault & \#32 & 1.9 & $\mathrm{~B}$ & & DNT-009-09 \\
\hline Arsenic & E04808001013A & Pump Pit & $\# 3$ & 7.7 & $\mathrm{BN}$ & $\mathrm{J}$ & DNT-009-09 \\
\hline Arsenic & E04808002013A & Pump Pit & $\# 12$ & 5.9 & $\mathrm{BN}$ & $\mathrm{J}$ & DNT-009-09 \\
\hline Arsenic & E04808003013A & Pump Pit & $\# 16$ & 6.3 & $\mathrm{BN}$ & $\mathrm{J}$ & DNT-009-09 \\
\hline Arsenic & E04808004013A & Pump Pit & \#18 & 4.5 & $\mathrm{BN}$ & $\mathrm{J}$ & DNT-009-09 \\
\hline Arsenic & E04808005013A & Pump Pit & \#23 & 4.4 & $\mathrm{BN}$ & $\mathrm{J}$ & DNT-009-09 \\
\hline Arsenic & E04808006013A & Tank Vault & $\# 8$ & 4.4 & $\mathrm{BN}$ & $\mathrm{J}$ & DNT-009-09 \\
\hline Arsenic & E04808007013A & Tank Vault & $\# 9$ & 6.1 & $\mathrm{BN}$ & $\mathrm{J}$ & DNT-009-09 \\
\hline Arsenic & E04808008013A & Tank Vault & $\# 15$ & 5.5 & $\mathrm{BN}$ & $\mathrm{J}$ & DNT-009-09 \\
\hline Arsenic & E04808009013A & Tank Vault & \#24 & 5.9 & $\mathrm{BN}$ & $\mathrm{J}$ & DNT-009-09 \\
\hline Arsenic & E04808010013A & Tank Vault & \#32 & 3.7 & $\mathrm{BN}$ & $\mathrm{J}$ & DNT-009-09 \\
\hline Barium & E04808001013A & Pump Pit & $\# 3$ & 88.8 & & & DNT-009-09 \\
\hline Barium & E04808002013A & Pump Pit & $\# 12$ & 97.6 & & & DNT-009-09 \\
\hline Barium & E04808003013A & Pump Pit & $\# 16$ & 124 & & & DNT-009-09 \\
\hline Barium & E04808004013A & Pump Pit & $\# 18$ & 108 & & & DNT-009-09 \\
\hline Barium & E04808005013A & Pump Pit & \#23 & 142 & & & DNT-009-09 \\
\hline Barium & E04808006013A & Tank Vault & $\# 8$ & 111 & & & DNT-009-09 \\
\hline Barium & E04808007013A & Tank Vault & $\# 9$ & 183 & & & DNT-009-09 \\
\hline Barium & E04808008013A & Tank Vault & $\# 15$ & 96.4 & & & DNT-009-09 \\
\hline Barium & E04808009013A & Tank Vault & $\# 24$ & 136 & & & DNT-009-09 \\
\hline Barium & E04808010013A & Tank Vault & \#32 & 111 & & & DNT-009-09 \\
\hline Beryllium & E04808001013A & Pump Pit & $\# 3$ & 0.41 & B & & DNT-009-09 \\
\hline Beryllium & E04808002013A & Pump Pit & $\# 12$ & 0.41 & B & & DNT-009-09 \\
\hline Beryllium & E04808003013A & Pump Pit & $\# 16$ & 0.45 & B & & DNT-009-09 \\
\hline Beryllium & E04808004013A & Pump Pit & $\# 18$ & 0.38 & B & & DNT-009-09 \\
\hline Beryllium & E04808005013A & Pump Pit & \#23 & 0.3 & B & & DNT-009-09 \\
\hline Beryllium & E04808006013A & Tank Vault & $\# 8$ & 0.4 & B & & DNT-009-09 \\
\hline Beryllium & E04808007013A & Tank Vault & $\# 9$ & 0.45 & B & & DNT-009-09 \\
\hline Beryllium & E04808008013A & Tank Vault & $\# 15$ & 0.31 & B & & DNT-009-09 \\
\hline Beryllium & E04808009013A & Tank Vault & $\# 24$ & 0.41 & B & & DNT-009-09 \\
\hline Beryllium & E04808010013A & Tank Vault & \#32 & 0.42 & B & & DNT-009-09 \\
\hline Cadmium & E04808001013A & Pump Pit & $\# 3$ & 0.27 & & & DNT-009-09 \\
\hline Cadmium & E04808002013A & Pump Pit & $\# 12$ & 0.23 & & & DNT-009-09 \\
\hline Cadmium & E04808003013A & Pump Pit & $\# 16$ & 0.38 & & & DNT-009-09 \\
\hline Cadmium & E04808004013A & Pump Pit & $\# 18$ & 0.3 & & & DNT-009-09 \\
\hline Cadmium & E04808005013A & Pump Pit & \#23 & 0.27 & & & DNT-009-09 \\
\hline Cadmium & E04808006013A & Tank Vault & $\# 8$ & 0.4 & & & DNT-009-09 \\
\hline Cadmium & E04808007013A & Tank Vault & $\# 9$ & 0.45 & & & DNT-009-09 \\
\hline Cadmium & E04808008013A & Tank Vault & $\# 15$ & 0.49 & & & DNT-009-09 \\
\hline Cadmium & E04808009013A & Tank Vault & $\# 24$ & 0.53 & & & DNT-009-09 \\
\hline Cadmium & E04808010013A & Tank Vault & \#32 & 0.45 & & & DNT-009-09 \\
\hline Chromium & E04808001013A & Pump Pit & $\# 3$ & 18.8 & $* \mathrm{~N}$ & $\mathrm{~J}$ & DNT-009-09 \\
\hline
\end{tabular}


Table G-5. (continued).

\begin{tabular}{|c|c|c|c|c|c|c|c|}
\hline Compound & $\begin{array}{c}\text { Field Sample } \\
\text { Number }\end{array}$ & Location & Grid & $\begin{array}{c}\text { Sample } \\
\text { Result } \\
(\mathrm{mg} / \mathrm{kg})\end{array}$ & $\begin{array}{l}\text { Result } \\
\text { Qual. }\end{array}$ & $\begin{array}{l}\text { Val. } \\
\text { Flag }\end{array}$ & $\begin{array}{c}\text { L\&V Report } \\
\text { Number }\end{array}$ \\
\hline Chromium & E04808002013A & Pump Pit & $\# 12$ & 17 & $* \mathrm{~N}$ & $\mathrm{~J}$ & DNT-009-09 \\
\hline Chromium & E04808003013A & Pump Pit & $\# 16$ & 20.4 & $* \mathrm{~N}$ & $\mathrm{~J}$ & DNT-009-09 \\
\hline Chromium & E04808004013A & Pump Pit & $\# 18$ & 20.6 & $* \mathrm{~N}$ & $\mathrm{~J}$ & DNT-009-09 \\
\hline Chromium & E04808005013A & Pump Pit & \#23 & 15.2 & $* \mathrm{~N}$ & $\mathrm{~J}$ & DNT-009-09 \\
\hline Chromium & E04808006013A & Tank Vault & $\# 8$ & 15.6 & $* \mathrm{~N}$ & $\mathrm{~J}$ & DNT-009-09 \\
\hline Chromium & E04808007013A & Tank Vault & $\# 9$ & 19.7 & $* \mathrm{~N}$ & $\mathrm{~J}$ & DNT-009-09 \\
\hline Chromium & E04808008013A & Tank Vault & $\# 15$ & 12.5 & $* \mathrm{~N}$ & $\mathrm{~J}$ & DNT-009-09 \\
\hline Chromium & E04808009013A & Tank Vault & $\# 24$ & 16.7 & $* \mathrm{~N}$ & $\mathrm{~J}$ & DNT-009-09 \\
\hline Chromium & E04808010013A & Tank Vault & \#32 & 13.9 & $* \mathrm{~N}$ & $\mathrm{~J}$ & DNT-009-09 \\
\hline Lead & E04808001013A & Pump Pit & $\# 3$ & 8.1 & $* \mathrm{~N}$ & $\mathrm{~J}$ & DNT-009-09 \\
\hline Lead & E04808002013A & Pump Pit & $\# 12$ & 8.4 & $* \mathrm{~N}$ & $\mathrm{~J}$ & DNT-009-09 \\
\hline Lead & E04808003013A & Pump Pit & $\# 16$ & 22 & $* \mathrm{~N}$ & $\mathrm{~J}$ & DNT-009-09 \\
\hline Lead & E04808004013A & Pump Pit & $\# 18$ & 7.9 & $* \mathrm{~N}$ & $\mathrm{~J}$ & DNT-009-09 \\
\hline Lead & E04808005013A & Pump Pit & \#23 & 6.8 & $* \mathrm{~N}$ & $\mathrm{~J}$ & DNT-009-09 \\
\hline Lead & E04808006013A & Tank Vault & $\# 8$ & 8.8 & $* \mathrm{~N}$ & $\mathrm{~J}$ & DNT-009-09 \\
\hline Lead & E04808007013A & Tank Vault & $\# 9$ & 9.1 & $* \mathrm{~N}$ & $\mathrm{~J}$ & DNT-009-09 \\
\hline Lead & E04808008013A & Tank Vault & $\# 15$ & 18.2 & $* \mathrm{~N}$ & $\mathrm{~J}$ & DNT-009-09 \\
\hline Lead & E04808009013A & Tank Vault & $\# 24$ & 9.9 & $* \mathrm{~N}$ & $\mathrm{~J}$ & DNT-009-09 \\
\hline Lead & E04808010013A & Tank Vault & \#32 & 10 & $* \mathrm{~N}$ & $\mathrm{~J}$ & DNT-009-09 \\
\hline Mercury & E04808001013A & Pump Pit & $\# 3$ & 0.52 & $*$ & $\mathrm{R}$ & DNT-009-09 \\
\hline Mercury & E04808002013A & Pump Pit & $\# 12$ & 0.12 & $*$ & $\mathrm{R}$ & DNT-009-09 \\
\hline Mercury & E04808003013A & Pump Pit & $\# 16$ & 0.13 & $*$ & $\mathrm{R}$ & DNT-009-09 \\
\hline Mercury & E04808004013A & Pump Pit & $\# 18$ & 0.032 & $\mathrm{~B}^{*}$ & $\mathrm{R}$ & DNT-009-09 \\
\hline Mercury & E04808005013A & Pump Pit & $\# 23$ & 0.027 & $\mathrm{~B}^{*}$ & $\mathrm{R}$ & DNT-009-09 \\
\hline Mercury & E04808006013A & Tank Vault & $\# 8$ & 0.02 & $\mathrm{~B}^{*}$ & $\mathrm{R}$ & DNT-009-09 \\
\hline Mercury & E04808007013A & Tank Vault & $\# 9$ & 0.023 & $\mathrm{~B}^{*}$ & $\mathrm{R}$ & DNT-009-09 \\
\hline Mercury & E04808008013A & Tank Vault & $\# 15$ & 0.019 & $\mathrm{~B}^{*}$ & $\mathrm{R}$ & DNT-009-09 \\
\hline Mercury & E04808009013A & Tank Vault & \#24 & 0.011 & $\mathrm{~B}^{*}$ & $\mathrm{R}$ & DNT-009-09 \\
\hline Mercury & E04808010013A & Tank Vault & \#32 & 0.029 & $\mathrm{~B}^{*}$ & $\mathrm{R}$ & DNT-009-09 \\
\hline Nickel & E04808001013A & Pump Pit & $\# 3$ & 18.2 & BEN & $\mathrm{J}$ & DNT-009-09 \\
\hline Nickel & E04808002013A & Pump Pit & $\# 12$ & 15.1 & BEN & $\mathrm{J}$ & DNT-009-09 \\
\hline Nickel & E04808003013A & Pump Pit & $\# 16$ & 16.8 & BEN & $\mathrm{J}$ & DNT-009-09 \\
\hline Nickel & E04808004013A & Pump Pit & $\# 18$ & 20.6 & BEN & $\mathrm{J}$ & DNT-009-09 \\
\hline Nickel & E04808005013A & Pump Pit & \#23 & 15.7 & BEN & $\mathrm{J}$ & DNT-009-09 \\
\hline Nickel & E04808006013A & Tank Vault & $\# 8$ & 15.9 & BEN & $\mathrm{J}$ & DNT-009-09 \\
\hline Nickel & E04808007013A & Tank Vault & $\# 9$ & 17.6 & BEN & $\mathrm{J}$ & DNT-009-09 \\
\hline Nickel & E04808008013A & Tank Vault & $\# 15$ & 13.8 & BEN & $\mathrm{J}$ & DNT-009-09 \\
\hline Nickel & E04808009013A & Tank Vault & $\# 24$ & 16 & BEN & $\mathrm{J}$ & DNT-009-09 \\
\hline Nickel & E04808010013A & Tank Vault & \#32 & 14.7 & $\mathrm{BEN}$ & $\mathrm{J}$ & DNT-009-09 \\
\hline Selenium & E04808001013A & Pump Pit & $\# 3$ & 0.58 & $\mathrm{~B}$ & & DNT-009-09 \\
\hline Selenium & E04808002013A & Pump Pit & $\# 12$ & 0.533 & $\mathrm{U}$ & & DNT-009-09 \\
\hline Selenium & E04808003013A & Pump Pit & $\# 16$ & 0.54 & $\mathrm{U}$ & & DNT-009-09 \\
\hline Selenium & E04808004013A & Pump Pit & $\# 18$ & 0.523 & $\mathrm{U}$ & & DNT-009-09 \\
\hline Selenium & E04808005013A & Pump Pit & \#23 & 0.51 & $\mathrm{U}$ & & DNT-009-09 \\
\hline Selenium & E04808006013A & Tank Vault & $\# 8$ & 0.538 & $\mathrm{U}$ & & DNT-009-09 \\
\hline Selenium & E04808007013A & Tank Vault & $\# 9$ & 0.522 & $\mathrm{U}$ & & DNT-009-09 \\
\hline Selenium & E04808008013A & Tank Vault & $\# 15$ & 0.519 & $\mathrm{U}$ & & DNT-009-09 \\
\hline Selenium & E04808009013A & Tank Vault & \#24 & 0.536 & $\mathrm{U}$ & & DNT-009-09 \\
\hline Selenium & E04808010013A & Tank Vault & \#32 & 0.55 & $\mathrm{~B}$ & & DNT-009-09 \\
\hline
\end{tabular}


Table G-5. (continued).

\begin{tabular}{|c|c|c|c|c|c|c|c|}
\hline Compound & $\begin{array}{c}\text { Field Sample } \\
\text { Number }\end{array}$ & Location & Grid & $\begin{array}{c}\text { Sample } \\
\text { Result } \\
(\mathrm{mg} / \mathrm{kg})\end{array}$ & $\begin{array}{l}\text { Result } \\
\text { Qual. }\end{array}$ & $\begin{array}{l}\text { Val. } \\
\text { Flag } \\
\end{array}$ & $\begin{array}{c}\text { L\&V Report } \\
\text { Number }\end{array}$ \\
\hline Silver & E04808001013A & Pump Pit & \#3 & 0.4 & & & DNT-009-09 \\
\hline Silver & E04808002013A & Pump Pit & $\# 12$ & 0.53 & & & DNT-009-09 \\
\hline Silver & E04808003013A & Pump Pit & $\# 16$ & 0.45 & & & DNT-009-09 \\
\hline Silver & E04808004013A & Pump Pit & $\# 18$ & 0.4 & & & DNT-009-09 \\
\hline Silver & E04808005013A & Pump Pit & \#23 & 0.36 & & & DNT-009-09 \\
\hline Silver & E04808006013A & Tank Vault & $\# 8$ & 0.12 & B & & DNT-009-09 \\
\hline Silver & E04808007013A & Tank Vault & $\# 9$ & 0.35 & & & DNT-009-09 \\
\hline Silver & E04808008013A & Tank Vault & $\# 15$ & 0.39 & & & DNT-009-09 \\
\hline Silver & E04808009013A & Tank Vault & $\# 24$ & 0.3 & & & DNT-009-09 \\
\hline Silver & E04808010013A & Tank Vault & \#32 & 0.36 & & & DNT-009-09 \\
\hline Thallium & E04808001013A & Pump Pit & \#3 & 0.16 & B & & DNT-009-09 \\
\hline Thallium & E04808002013A & Pump Pit & $\# 12$ & 0.14 & B & & DNT-009-09 \\
\hline Thallium & E04808003013A & Pump Pit & $\# 16$ & 0.17 & B & & DNT-009-09 \\
\hline Thallium & E04808004013A & Pump Pit & $\# 18$ & 0.13 & B & & DNT-009-09 \\
\hline Thallium & E04808005013A & Pump Pit & $\# 23$ & 0.13 & B & & DNT-009-09 \\
\hline Thallium & E04808006013A & Tank Vault & $\# 8$ & 0.16 & $\mathrm{~B}$ & & DNT-009-09 \\
\hline Thallium & E04808007013A & Tank Vault & $\# 9$ & 0.19 & B & & DNT-009-09 \\
\hline Thallium & E04808008013A & Tank Vault & $\# 15$ & 0.12 & B & & DNT-009-09 \\
\hline Thallium & E04808009013A & Tank Vault & $\# 24$ & 0.14 & B & & DNT-009-09 \\
\hline Thallium & E04808010013A & Tank Vault & \#32 & 0.14 & $\mathrm{~B}$ & & DNT-009-09 \\
\hline Vanadium & E04808001013A & Pump Pit & \#3 & 28.7 & & & DNT-009-09 \\
\hline Vanadium & E04808002013A & Pump Pit & $\# 12$ & 26.6 & & & DNT-009-09 \\
\hline Vanadium & E04808003013A & Pump Pit & $\# 16$ & 33.3 & & & DNT-009-09 \\
\hline Vanadium & E04808004013A & Pump Pit & $\# 18$ & 24.8 & & & DNT-009-09 \\
\hline Vanadium & E04808005013A & Pump Pit & $\# 23$ & 20.9 & & & DNT-009-09 \\
\hline Vanadium & E04808006013A & Tank Vault & $\# 8$ & 26.7 & & & DNT-009-09 \\
\hline Vanadium & E04808007013A & Tank Vault & $\# 9$ & 30 & & & DNT-009-09 \\
\hline Vanadium & E04808008013A & Tank Vault & $\# 15$ & 20.2 & & & DNT-009-09 \\
\hline Vanadium & E04808009013A & Tank Vault & $\# 24$ & 26.8 & & & DNT-009-09 \\
\hline Vanadium & E04808010013A & Tank Vault & $\# 32$ & 22.8 & & & DNT-009-09 \\
\hline Zinc & E04808001013A & Pump Pit & \#3 & 45 & & & DNT-009-09 \\
\hline Zinc & E04808002013A & Pump Pit & $\# 12$ & 45.5 & & & DNT-009-09 \\
\hline Zinc & E04808003013A & Pump Pit & $\# 16$ & 51.9 & & & DNT-009-09 \\
\hline Zinc & E04808004013A & Pump Pit & $\# 18$ & 44.9 & & & DNT-009-09 \\
\hline Zinc & E04808005013A & Pump Pit & \#23 & 32.2 & & & DNT-009-09 \\
\hline Zinc & E04808006013A & Tank Vault & $\# 8$ & 72.1 & & & DNT-009-09 \\
\hline Zinc & E04808007013A & Tank Vault & $\# 9$ & 66.2 & & & DNT-009-09 \\
\hline Zinc & E04808008013A & Tank Vault & $\# 15$ & 43.9 & & & DNT-009-09 \\
\hline Zinc & E04808009013A & Tank Vault & $\# 24$ & 48.9 & & & DNT-009-09 \\
\hline Zinc & E04808010013A & Tank Vault & $\# 32$ & 51.3 & & & DNT-009-09 \\
\hline $\begin{array}{l}\text { Explanation of Res } \\
\qquad \begin{array}{r}*=\text { A quality c } \\
B=\text { Either pres } \\
\mathrm{N}=\text { The Matri } \\
\mathrm{E}=\% \text { differen } \\
\mathrm{U}=\text { Compounc }\end{array}\end{array}$ & $\begin{array}{l}\text { alifiers } \\
\text { analyte recovery is ov } \\
\text { f analyte detected in } \\
\text { sample recovery is } n \\
\text { ample and SD is }>10 \\
\text { ot detected at metho }\end{array}$ & $\begin{array}{l}\text { le of specified } \\
\text { ssociated blan } \\
\text { ithin specified } \\
\text { ample concent } \\
\text { tection limit }\end{array}$ & $\begin{array}{l}\text { eptance } \\
\text { r MDI } \\
\text { ntrol li } \\
\text { on mus }\end{array}$ & $\begin{array}{l}<\text { sample } \\
\text { et flagging }\end{array}$ & $\begin{array}{l}<\mathrm{PQL} \\
\text { ria }\end{array}$ & & \\
\hline \multicolumn{8}{|c|}{ Explanation of Validation Flags } \\
\hline $\begin{array}{l}\mathrm{J}=\text { Compound } \\
\mathrm{R}=\text { Data reject }\end{array}$ & $\begin{array}{l}\text { ed, but reported value } \\
\text { use as a result of vari }\end{array}$ & $\begin{array}{l}\text { In estimate due } \\
\text { QC issues iden }\end{array}$ & $\begin{array}{l}\text { various } \\
\text { led in } \mathrm{L}\end{array}$ & $\begin{array}{l}\text { concerns a } \\
\text { report }\end{array}$ & & & \\
\hline
\end{tabular}


G-50 
Appendix $\mathrm{H}$

\section{ProUCL Evaluation of Analytes}


H-2 


\section{Appendix $\mathrm{H}$}

\section{ProUCL Evaluation of Analytes}

The U.S. Enivronmental Protection Agency-provided statistical software ProUCL was used to evaluate the data from sampling of the soils beneath the former location of VES-SFE-20. The software recommended both a statistical distribution and 95\% upper confidence limit for use based upon the data entered. These recommendations were accepted for use in this data evaluation.

The following printouts from the ProUCL software differentiate between valid observations and distinct observations. The number reported for valid observations is representative of the actual number of data points as reported by the laboratory. The number of distinct observations represents only unique numeric values and will either be equal to or, if there are duplicate values reported by the laboratory, less than the number of valid observations. 


\author{
User Selected Options \\ From File WorkSheet.wst \\ Full Precision OFF \\ Confidence Coefficient $95 \%$ \\ Number of Bootstrap Operations 2000
}

\section{Am-241 w/NDs at LOD}

\author{
General Statistics \\ Number of Valid Observations 10 \\ Raw Statistics \\ Minimum 0.00126 \\ Maximum 0.242 \\ Mean 0.0466 \\ Median 0.0342 \\ SD 0.0699 \\ Coefficient of Variation 1.5 \\ Skewness 2.948 \\ Normal Distribution Test \\ Shapiro Wilk Test Statistic 0.543 \\ Shapiro Wilk Critical Value 0.842 \\ Data not Normal at $5 \%$ Significance Level \\ Assuming Normal Distribution \\ 95\% Student's-t UCL 0.0871 \\ 95\% UCLs (Adjusted for Skewness) \\ 95\% Adjusted-CLT UCL 0.105 \\ 95\% Modified-t UCL 0.0906 \\ Gamma Distribution Test \\ k star (bias corrected) 0.666 \\ Theta Star 0.07 \\ nu star 13.32 \\ Approximate Chi Square Value (.05) 6.109 \\ Adjusted Level of Significance 0.0267 \\ Adjusted Chi Square Value 5.284 \\ Anderson-Darling Test Statistic 0.799 \\ Anderson-Darling 5\% Critical Value 0.753 \\ Kolmogorov-Smirnov Test Statistic 0.322 \\ Kolmogorov-Smirnov $5 \%$ Critical Value 0.275 \\ Data not Gamma Distributed at $5 \%$ Significance Level \\ Assuming Gamma Distribution \\ 95\% Approximate Gamma UCL 0.102 \\ 95\% Adjusted Gamma UCL 0.118 \\ Potential UCL to Use
}

\section{Number of Distinct Observations 10}

Log-transformed Statistics

Minimum of Log Data -6.677 Maximum of Log Data -1.419

Mean of log Data -3.753 SD of log Data 1.326
Lognormal Distribution Test

Shapiro Wilk Test Statistic 0.874

Shapiro Wilk Critical Value 0.842

Data appear Lognormal at 5\% Significance Level

Assuming Lognormal Distribution

95\% H-UCL 0.304

$95 \%$ Chebyshev (MVUE) UCL 0.144

$97.5 \%$ Chebyshev (MVUE) UCL 0.185

$99 \%$ Chebyshev (MVUE) UCL 0.266

Data Distribution

Data appear Lognormal at $5 \%$ Significance Level

Nonparametric Statistics

95\% CLT UCL 0.083

$95 \%$ Jackknife UCL 0.0871

95\% Standard Bootstrap UCL 0.0806 95\% Bootstrap-t UCL 0.185

$95 \%$ Hall's Bootstrap UCL 0.251

95\% Percentile Bootstrap UCL 0.0885

95\% BCA Bootstrap UCL 0.111

95\% Chebyshev(Mean, Sd) UCL 0.143

97.5\% Chebyshev(Mean, Sd) UCL 0.185

$99 \%$ Chebyshev(Mean, Sd) UCL 0.267

Use $95 \%$ Chebyshev (MVUE) UCL 0.144 


\author{
User Selected Options \\ From File \\ Full Precision \\ Confidence Coefficient \\ Number of Bootstrap Operations \\ Cesium-137 \\ General Statistics \\ Number of Valid Observations \\ Number of Missing Values \\ Raw Statistics \\ Minimum \\ Maximum \\ Mean \\ Median \\ SD \\ Coefficient of Variation \\ Skewness \\ Relevant UCL Statistics \\ Normal Distribution Test \\ Shapiro Wilk Test Statistic \\ Shapiro Wilk Critical Value \\ Data not Normal at $5 \%$ Significance Level \\ Assuming Normal Distribution \\ 95\% Student's-t UCL \\ 95\% UCLs (Adjusted for Skewness) \\ 95\% Adjusted-CLT UCL \\ 95\% Modified-t UCL \\ Gamma Distribution Test \\ k star (bias corrected) \\ Theta Star \\ nu star \\ Approximate Chi Square Value (.05) \\ Adjusted Level of Significance \\ Adjusted Chi Square Value \\ Anderson-Darling Test Statistic \\ Anderson-Darling $5 \%$ Critical Value \\ Kolmogorov-Smirnov Test Statistic \\ Kolmogorov-Smirnov $5 \%$ Critical Value \\ Data appear Gamma Distributed at $5 \%$ Significance Level \\ Assuming Gamma Distribution \\ 95\% Approximate Gamma UCL \\ 95\% Adjusted Gamma UCL \\ WorkSheet.wst \\ OFF \\ $95 \%$
}

Potential UCL to Use
General UCL Statistics for Full Data Sets

10 Number of Distinct Observations

Log-transformed Statistics

8.64 Minimum of Log Data

5730 Maximum of Log Data

1346 Mean of log Data

412 SD of $\log$ Data

1956

1.454

1.574

2.156

8.653

5.701

2.209

0.733 Shapiro Wilk Test Statistic

0.944

0.842 Shapiro Wilk Critical Value

0.842

Data appear Lognormal at $5 \%$ Significance Level

Assuming Lognormal Distribution

$248095 \% \mathrm{H}-\mathrm{UCL}$

95\% Chebyshev (MVUE) UCL

$269297.5 \%$ Chebyshev (MVUE) UCL

$253199 \%$ Chebyshev (MVUE) UCL

265160

8010

10624

15758

Data Distribution

0.369 Data appear Gamma Distributed at $5 \%$ Significance Level

3645

7.383

2.383 Nonparametric Statistics

$0.026795 \%$ CLT UCL

$1.9295 \%$ Jackknife UCL

$0.351 \quad 95 \%$ Bootstrap-t UCL

$0.78995 \%$ Hail's Bootstrap UCL

$0.28395 \%$ BCA Bootstrap UCL

95\% Chebyshev(Mean, Sd) UCL

4169

5175

Use $95 \%$ Adjusted Gamma UCL

5175 
General UCL Statistics for Full Data Sets

User Selected Options

From File WorkSheet.wst

Full Precision OFF

Confidence Coefficient 95\%

Number of Bootstrap Operations 2000

\section{Pu-238 w/NDs at LOD}

Number of Valid Observations 10

General Statistics

Raw Statistics

$$
\begin{aligned}
& \text { Minimum } 0.00904 \\
& \text { Maximum } 0.716 \\
& \text { Mean } 0.142 \\
& \text { Median } 0.0798 \\
& \text { SD } 0.21 \\
& \text { Coefficient of Variation } 1.479 \\
& \text { Skewness } 2.719
\end{aligned}
$$

Number of Distinct Observations 10

Log-transformed Statistics

Minimum of Log Data -4.706

Maximum of Log Data -0.334

Mean of log Data -2.683

SD of log Data 1.315

Relevant UCL Statistics

Assuming Gamma Distribution

95\% Approximate Gamma UCL 0.318

95\% Adjusted Gamma UCL 0.369

Potential UCL to Use

Lognormal Distribution Test

Shapiro Wilk Test Statistic 0.942 Shapiro Wilk Critical Value 0.842

Data appear Lognormal at $5 \%$ Significance Level

Assuming Lognormal Distribution

95\% H-UCL 0.852

95\% Chebyshev (MVUE) UCL 0.414

97.5\% Chebyshev (MVUE) UCL 0.531

$99 \%$ Chebyshev (MVUE) UCL 0.762

Data Distribution

Data appear Gamma Distributed at 5\% Significance Level

Nonparametric Statistics

95\% CLT UCL 0.252

$95 \%$ Jackknife UCL 0.264

95\% Standard Bootstrap UCL 0.245 95\% Bootstrap-t UCL 0.602

$95 \%$ Hall's Bootstrap UCL 0.763

95\% Percentile Bootstrap UCL 0.264

95\% BCA Bootstrap UCL 0.331

$95 \%$ Chebyshev(Mean, Sd) UCL 0.432

$97.5 \%$ Chebyshev(Mean, Sd) UCL 0.558

99\% Chebyshev(Mean, Sd) UCL 0.804

Use 95\% Approximate Gamma UCL 0.318 
General UCL Statistics for Full Data Sets

User Selected Options
From File
Full Precision

Number of Bootstrap Operations 2000

\section{Pu-239 w/NDs at LOD}

\author{
General Statistics \\ Number of Valid Observations 10 \\ Raw Statistics \\ Minimum 0.0175 \\ Maximum 2.42 \\ Mean 0.457 \\ Median 0.17 \\ SD 0.736 \\ Coefficient of Variation 1.61 \\ Skewness 2.557 \\ Normal Distribution Test \\ Relevant UCL Statistics \\ Shapiro Wilk Test Statistic 0.628 \\ Shapiro Wilk Critical Value 0.842 \\ Data not Normal at $5 \%$ Significance Level \\ Assuming Normal Distribution \\ 95\% Student's-t UCL 0.884 \\ 95\% UCLs (Adjusted for Skewness) \\ 95\% Adjusted-CLT UCL 1.041 \\ 95\% Modified-t UCL 0.915 \\ Gamma Distribution Test \\ k star (bias corrected) 0.526 \\ Theta Star 0.87 \\ nu star 10.51 \\ Approximate Chi Square Value (.05) 4.263 \\ Adjusted Level of Significance 0.0267 \\ Adjusted Chi Square Value 3.598 \\ Anderson-Darling Test Statistic 0.403 \\ Anderson-Darling $5 \%$ Critical Value 0.765 \\ Kolmogorov-Smirnov Test Statistic 0.189 \\ Kolmogorov-Smirnov $5 \%$ Critical Value 0.278 \\ Data appear Gamma Distributed at $5 \%$ Significance Level \\ Assuming Gamma Distribution \\ 95\% Approximate Gamma UCL 1.127 \\ 95\% Adjusted Gamma UCL 1.335 \\ Potential UCL to Use
}

Number of Distinct Observations 10

Log-transformed Statistics

Minimum of Log Data -4.046

Maximum of Log Data 0.884

Mean of log Data -1.713

SD of log Data 1.465

Lognormal Distribution Test

Shapiro Wilk Test Statistic 0.989 Shapiro Wilk Critical Value 0.842

Data appear Lognormal at $5 \%$ Significance Level

Assuming Lognormal Distribution

95\% H-UCL 3.959

95\% Chebyshev (MVUE) UCL 1.383

97.5\% Chebyshev (MVUE) UCL 1.79

99\% Chebyshev (MVUE) UCL 2.59

Data Distribution

Data appear Gamma Distributed at 5\% Significance Level

Nonparametric Statistics

95\% CLT UCL 0.84 95\% Jackknife UCL 0.884

$95 \%$ Standard Bootstrap UCL 0.813 95\% Bootstrap-t UCL 2.345

95\% Hall's Bootstrap UCL 2.502

95\% Percentile Bootstrap UCL 0.864

95\% BCA Bootstrap UCL 1.092

$95 \%$ Chebyshev(Mean, Sd) UCL 1.471

97.5\% Chebyshev(Mean, Sd) UCL 1.91

99\% Chebyshev(Mean, Sd) UCL 2.772

Use 95\% Approximate Gamma UCL 1.127 


$\begin{aligned} & \text { General UCL Statistics for Full Data Sets } \\ \text { User Selected Options } & \\ \text { From File } & \text { WorkSheet.wst } \\ \text { Full Precision } & \text { OFF } \\ \text { Confidence Coefficient } & 95 \% \\ \text { Number of Bootstrap Operations } & 2000 \\ & \\ \text { Sr-90 } & \end{aligned}$

Number of Valid Observations 10

General Statistics

Raw Statistics

$$
\begin{aligned}
\text { Minimum } 264 \\
\text { Maximum } 16400 \\
\text { Mean } 4380 \\
\text { Median } 3045 \\
\text { SD } 5063 \\
\text { f Variation } 1.156 \\
\text { Skewness } 1.756
\end{aligned}
$$

Coefficient of Variation 1.156
Number of Distinct Observations 9

Log-transformed Statistics

Minimum of Log Data 5.576

Maximum of Log Data 9.705

Mean of log Data 7.718

SD of log Data 1.318

Normal Distribution Test

Relevant UCL Statistics

Shapiro Wilk Test Statistic 0.791

Shapiro Wilk Critical Value 0.842

Data not Normal at $5 \%$ Significance Level

Assuming Normal Distribution

95\% Student's-t UCL 7315

95\% UCLs (Adjusted for Skewness)

95\% Adjusted-CLT UCL 7964

95\% Modified-t UCL 7463

Gamma Distribution Test

k star (bias corrected) 0.682

Theta Star 6424

nu star 13.64

Approximate Chi Square Value (.05) 6.324

Adjusted Level of Significance 0.0267

Adjusted Chi Square Value 5.482

Anderson-Darling Test Statistic 0.269

Anderson-Darling 5\% Critical Value 0.752

Kolmogorov-Smirnov Test Statistic 0.184

Kolmogorov-Smirnov $5 \%$ Critical Value 0.275

Data appear Gamma Distributed at 5\% Significance Level

Assuming Gamma Distribution

95\% Approximate Gamma UCL 9446

95\% Adjusted Gamma UCL 10897

Potential UCL to Use

Lognormal Distribution Test

Shapiro Wilk Test Statistic 0.963

Shapiro Wilk Critical Value 0.842

Data appear Lognormal at $5 \%$ Significance Level

Assuming Lognormal Distribution

95\% H-UCL 28318

95\% Chebyshev (MVUE) UCL 13672

97.5\% Chebyshev (MVUE) UCL 17563

99\% Chebyshev (MVUE) UCL 25205

Data Distribution

Data appear Gamma Distributed at 5\% Significance Level

Nonparametric Statistics

95\% CLT UCL 7014 95\% Jackknife UCL 7315

$95 \%$ Standard Bootstrap UCL. 6918 95\% Bootstrap-t UCL 10891

$95 \%$ Hall's Bootstrap UCL 2070

95\% Percentile Bootstrap UCL 7119

95\% BCA Bootstrap UCL 7788

95\% Chebyshev(Mean, Sd) UCL 11359

97.5\% Chebyshev(Mean, Sd) UCL 14379

99\% Chebyshev(Mean, Sd) UCL 20310

Use 95\% Approximate Gamma UCL 9446 


$\begin{array}{ll}\text { User Selected Options } & \text { General UCL S } \\ \text { From File } & \text { WorkSheet.wst } \\ \text { Full Precision } & \text { OFF } \\ \text { Confidence Coefficient } & 95 \% \\ \text { Number of Bootstrap Operations } & \end{array}$

Uranium-233

General Statistics

Number of Valid Observations

10 Number of Distinct Observations

Number of Missing Values

1

Raw Statistics

Minimum

Maximum

Mean

Median

SD

Coefficient of Variation

Skewness

Log-transformed Statistics

1.05 Minimum of Log Data

21 Maximum of Log Data

0.793

.377 Mean of log Data $\quad 0.283$

1.215 SD of log Data $\quad 0.274$

0.436

0.316

1.597

Relevant UCL Statistics

Normal Distribution Test

Shapiro Wilk Test Statistic

Shapiro Wilk Critical Value

Data not Nomal at $5 \%$ Significance Leve

Lognormal Distribution Test

0.695 Shapiro Wilk Test Statistic

0.842 Shapiro Wilk Critical Value

Data not Lognormal at $5 \%$ Significance Level

0.749

Assuming Normal Distribution

$95 \%$ Student's-t UCL

95\% UCLs (Adjusted for Skewness)

95\% Adjusted-CLT UCL

$95 \%$ Modified-t UCL

Gamma Distribution Test

k star (bias corrected)

Theta Star

nu star

Approximate Chi Square Value $(.05\}$

Adjusted Level of Significance

Adjusted Chi Square Value

Anderson-Darling Test Statistic

Anderson-Darling $5 \%$ Critical Value

Kolmogorov-Smirnov Test Statistic

Kolmogorov-Smirnov $5 \%$ Critical Value

Data not Gamma Distributed at 5\% Significance Level

Assuming Gamma Distribution

95\% Approximate Gamma UCL

Assuming Lognormal Distribution

$1.6395 \% \mathrm{H}-\mathrm{UCL}$

$95 \%$ Chebyshev (MVUE) UCL

Dyshev (MVUE) UCL 2.118

$\begin{array}{ll}1.64199 \% \text { Chebysher (MVUE) UCL. } & 2.561\end{array}$

Data Distribution

9.582 Data do not follow a Discemable Distribution (0.05)

0.144

191.6

160.6 Nonparametric Statistics

$0.026795 \%$ CLT UCL

$155.795 \%$ Jackknife UCL

$1.28495 \%$ Bootstrap-t UCL.

$0.72595 \%$ Hall's Bootstrap UCL

$0.30395 \%$ Percentile Bootstrap UCL

$0.26695 \%$ BCA Bootstrap UCL

95\% Chebyshev(Mean, Sd) UCL

97.5\% Chebyshev(Mean, Sd) UCL

$99 \%$ Chebyshev(Mean, Sd) UCL

1.604

1.63

1.596

2.297

3.071

1.599

1.661

1.978

1.643

95\% Adjusted Gamma UCL

1.695

Potential UCL to Use

Use $95 \%$ Student's-1 UCL

1.63

or $95 \%$ Modified-t UCL

1.641 


\author{
User Selected Options \\ Full Precision \\ Confidence Coefficient \\ Number of Bootstrap Operations \\ WorkSheet.wst \\ OFF \\ $95 \%$ \\ Uranium-235 \\ General Statistics \\ Number of Valid Observations \\ Number of Missing Values \\ Raw Statistics \\ Minimum \\ Maximum \\ Mean \\ Median \\ SD \\ Coefficient of Variation \\ Skewness \\ Relevant UCL Statistics \\ Normal Distribution Test \\ Shapiro Wilk Test Statistic \\ Shapiro Wilk Critical Value \\ Data appear Normal at $5 \%$ Significance Level \\ Assuming Normal Distribution \\ 95\% Student's-t UCL \\ 95\% UCLs (Adjusted for Skewness) \\ 95\% Adjusted-CLT UCL \\ $95 \%$ Modified-t UCL \\ Gamma Distribution Test \\ k star (bias corrected) \\ Theta Star \\ nu star \\ Approximate Chi Square Value (.05) \\ Adjusted Level of Significance \\ Adjusted Chi Square Value \\ Anderson-Darling Test Statistic \\ Anderson-Darling $5 \%$ Critical Value \\ Kolmogorov-Sminov Test Statistic \\ Kolmogorov-Smirnov $5 \%$ Critical Value \\ Data appear Gamma Distributed at 5\% Significance Level \\ Assuming Gamma Distribution \\ 95\% Approximate Gamma UCL \\ 95\% Adjusted Gamma UCL
}

General UCL Statistics for Full Data Sets

Potential UCL to Use
10 Number of Distinct Observations

Log-transformed Statistics

0.043 Minimum of Log Data

0.181 Maximum of Log Data

0.0931 Mean of $\log D$

0.525

1.119

Lognormal Distribution Test

0.846 Shapiro Wilk Test Statistic

0.842 Shapiro Wilk Critical Value

Data appear Lognormal at $5 \%$ Significance Level

Assuming Lognormal Distribution

$0.12195 \% \mathrm{H}-\mathrm{UCL}$

$95 \%$ Chebyshev (MVUE) UCL

$0.12497 .5 \%$ Chebyshev (MVUE) UCL

$0.12299 \%$ Chebyshev (MVUE) UCL

Data Distribution

3.318 Data appear Normal at 5\% Significance Level

0.0281

66.37

48.62 Nonperametric Statistics

$0.026795 \%$ CLT UCL

$45.9995 \%$ Jackknife UCL

$0.409 \quad 95 \%$ Bootstap-1UCL

$0.72995 \%$ Hall's Bootstrap UCL

$0.186 \quad 95 \%$ Percentile Bootstrap UCL

$0.268 \quad 95 \%$ BCA Bootstrap UCL

95\% Chebyshev(Mean, Sd) UCL

97.5\% Chebyshev(Mean, Sd) UCL

$99 \%$ Chebyshev(Mean, Sd) UCL

0.127

0.134

Use $95 \%$ Student's-t UCL
10

0.939

0.842

0.134

0.156

0.183

0.237

0.119

0.117

0.143

0.121

0.16

\section{0}

0.487

0.247

0.121 


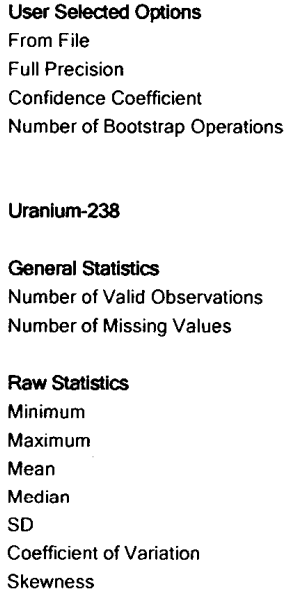

Anderson-Darling Test Statistic Anderson-Darling 5\% Critical Value

Potential UCL to Use
10 Number of Distinct Observations 1

Log-transformed Statistics

0.96 Minimum of Log Data

1.34 Maximum of Log Data

1.127 Mean of $\log$ Data

$1.1 \mathrm{SD}$ of $\log$ Data

0.112

0.0996

0.728

normal Distribution Test

0.926 Shapiro Wilk Test Statistic

0.842 Shapiro Wilk Critical Value

0.941

Data appear Lognormal at $5 \%$ Significance Level

Assuming Lognormal Distribution

$1.19295 \% \mathrm{H}-\mathrm{UCL}$

$95 \%$ Chebyshev (MVUE) UCL

N/A

$1.19497 .5 \%$ Chebyshev (MVUE) UCL

1.279

1.344

$1.19399 \%$ Chebyshev (MVUE) UCL

1.473

Data Distribution

80.82 Data appear Normal at $5 \%$ Significance Level

0.0139

1524 Nonparametric Statistics

$0.026795 \%$ CLT UCL

1508 95\% Jackknife UCL

\begin{tabular}{lll}
1.185 \\
\hline
\end{tabular}

$0.43295 \%$ Bootstrap-t UCL

$0.72495 \%$ Hall's Bootstrap UCL

$0.25295 \%$ Percentile Bootstrap UCL

$0.26695 \%$ BCA Bootstrap UCL

95\% Chebyshev(Mean, Sd) UCL

97.5\% Chebyshev(Mean, Sd) UCL

$99 \%$ Chebyshev(Mean, Sd) UCL

0.115

0.0976

1.195

1.208

Use $95 \%$ Student's-t UCL 
General UCL Statistics for Full Data Sets

User Selected Options

From File WorkSheet.wst

Full Precision OFF

Confidence Coefficient $95 \%$

Number of Bootstrap Operations $\quad 2000$

\section{Chloroform w/NDs at DL}

\author{
General Statistics \\ Number of Valid Observations 10 \\ Raw Statistics

$$
\begin{aligned}
& \text { Minimum } 0.469 \\
& \text { Maximum } 4.12 \\
& \text { Mean } 1.801 \\
& \text { Median } 1.395 \\
& \text { SD } 1.301
\end{aligned}
$$ \\ Coefficient of Variation 0.722 \\ Skewness 1.021 \\ Relevant UCL Statistics \\ Normal Distribution Test \\ Shapiro Wilk Test Statistic 0.856 \\ Shapiro Wilk Critical Value 0.842 \\ Data appear Normal at 5\% Significance Level \\ Assuming Normal Distribution \\ 95\% Student's-t UCL 2.555 \\ 95\% UCLs (Adjusted for Skewness) \\ 95\% Adjusted-CLT UCL 2.619 \\ 95\% Modified-t UCL 2.577 \\ Gamma Distribution Test \\ k star (bias corrected) 1.668 \\ Theta Star 1.079 \\ nu star 33.36 \\ Approximate Chi Square Value (.05) 21.16 \\ Adjusted Level of Significance 0.0267 \\ Adjusted Chi Square Value 19.48 \\ Anderson-Darling Test Statistic 0.329 \\ Anderson-Darling 5\% Critical Value 0.735 \\ Kolmogorov-Smirnov Test Statistic 0.189 \\ Kolmogorov-Smirnov 5\% Critical Value 0.269 \\ Data appear Gamma Distributed at $5 \%$ Significance Level \\ Assuming Gamma Distribution \\ 95\% Approximate Gamma UCL 2.84 \\ 95\% Adjusted Gamma UCL 3.083 \\ Potential UCL to Use
}

Number of Distinct Observations 10

Log-transformed Statistics

Minimum of Log Data -0.757

Maximum of Log Data 1.416

Mean of log Data 0.354

SD of log Data 0.728
Lognormal Distribution Test

Shapiro Wilk Test Statistic 0.955 Shapiro Wilk Critical Value 0.842

Data appear Lognormal at $5 \%$ Significance Level

Assuming Lognormal Distribution

95\% H-UCL 3.473

95\% Chebyshev (MVUE) UCL 3.664

$97.5 \%$ Chebyshev (MVUE) UCL 4.471

$99 \%$ Chebyshev (MVUE) UCL 6.055

Data Distribution

Data appear Normal at 5\% Significance Level

Nonparametric Statistics

95\% CLT UCL 2.477 $95 \%$ Jackknife UCL 2.55

$95 \%$ Standard Bootstrap UCL 2.443 95\% Bootstrap-t UCL 2.978

$95 \%$ Hall's Bootstrap UCL 3.045

95\% Percentile Bootstrap UCL 2.464

95\% BCA Bootstrap UCL 2.577

95\% Chebyshev(Mean, Sd) UCL 3.594

$97.5 \%$ Chebyshev(Mean, Sd) UCL 4.37

$99 \%$ Chebyshev(Mean, Sd) UCL 5.894

Use $95 \%$ Student's-t UCL 2.555 


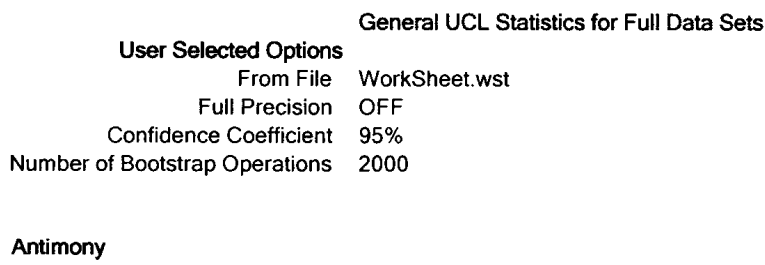

Antimony

General Statistics

Number of Valid Observations 10

Number of Distinct Observations 6

Log-transformed Statistics

Minimum of Log Data -0.010

Maximum of Log Data 0.642

Mean of log Data 0.386

SD of log Data 0.205

Mean 1.499

dian 1.45

Coefficient of Variation 0.198

Skewness -0.0602

Normal Distribution Test

Relevant UCL Statistics

Shapiro Wilk Test Statistic 0.932

Shapiro Wilk Critical Value 0.842

Data appear Normal at $5 \%$ Significance Level

Assuming Normal Distribution

95\% Student's-t UCL 1.671

95\% UCLs (Adjusted for Skewness)

95\% Adjusted-CLT UCL 1.65

95\% Modified-t UCL 1.67

Gamma Distribution Test

k star (bias corrected) 19.2 Theta Star 0.0781

nu star 384

Approximate Chi Square Value (.05) 339.6

Adjusted Level of Significance 0.0267

Adjusted Chi Square Value 332.3

Anderson-Darling Test Statistic 0.361

Anderson-Darling 5\% Critical Value 0.725

Kolmogorov-Smirnov Test Statistic 0.169

Kolmogorov-Smirnov 5\% Critical Value 0.266

Data appear Gamma Distributed at $5 \%$ Significance Level

Assuming Gamma Distribution

95\% Approximate Gamma UCL 1.695 95\% Adjusted Gamma UCL 1.732

Potential UCL to Use

Lognormal Distribution Test

Shapiro Wilk Test Statistic 0.927

Shapiro Wilk Critical Value 0.842

Data appear Lognormal at 5\% Significance Level

Assuming Lognormal Distribution

95\% H-UCL 1.71

95\% Chebyshev (MVUE) UCL 1.925

97.5\% Chebyshev (MVUE) UCL 2.109

$99 \%$ Chebyshev (MVUE) UCL 2.47

Data Distribution

Data appear Normal at $5 \%$ Significance Level

Nonparametric Statistics

95\% CLT UCL 1.653 95\% Jackknife UCL 1.671 95\% Standard Bootstrap UCL 1.647 $95 \%$ Bootstrap-t UCL 1.668

$95 \%$ Hall's Bootstrap UCL 1.652

95\% Percentile Bootstrap UCL 1.64 95\% BCA Bootstrap UCL 1.63

95\% Chebyshev(Mean, Sd) UCL 1.907

97.5\% Chebyshev(Mean, Sd) UCL 2.084

$99 \%$ Chebyshev(Mean, Sd) UCL 2.431

Use $95 \%$ Student's-t UCL 1.671 


$\begin{aligned} \text { User Selected Options } & \text { General UCL Statistics for Full Data Sets } \\ \text { From File } & \text { WorkSheet.wst } \\ \text { Full Precision } & \text { OFF } \\ \text { Confidence Coefficient } & 95 \% \\ \text { of Bootstrap Operations } & 2000 \\ & \end{aligned}$

Arsenic

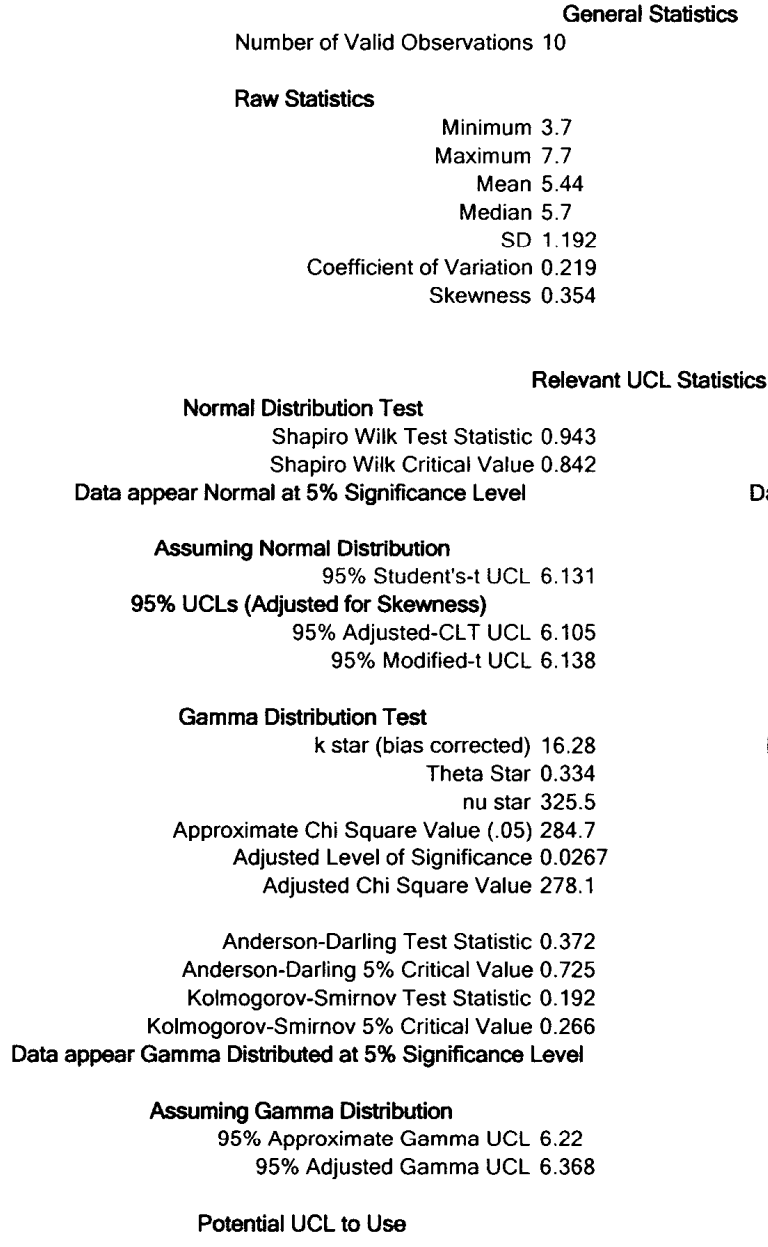

Number of Distinct Observations 8

Log-transformed Statistics

Minimum of Log Data 1.308

Maximum of Log Data 2.041

Mean of log Data 1.672

SD of log Data 0.221

\author{
Lognormal Distribution Test \\ Shapiro Wilk Test Statistic 0.948 \\ Shapiro Wilk Critical Value 0.842 \\ Data appear Lognormal at 5\% Significance Level
}

Assuming Lognormal Distribution

95\% H-UCL 6.272

95\% Chebyshev (MVUE) UCL 7.103

$97.5 \%$ Chebyshev (MVUE) UCL 7.822

$99 \%$ Chebyshev (MVUE) UCL 9.234

Data Distribution

Data appear Normal at $5 \%$ Significance Level

Nonparametric Statistics

95\% CLT UCL 6.06 95\% Jackknife UCL 6.131 $95 \%$ Standard Bootstrap UCL 6.019 $95 \%$ Bootstrap-t UCL 6.142

95\% Hall's Bootstrap UCL 6.187 95\% Percentile Bootstrap UCL 6.04

$95 \%$ BCA Bootstrap UCL 6.07

95\% Chebyshev(Mean, Sd) UCL 7.083

97.5\% Chebyshev(Mean, Sd) UCL 7.794

$99 \%$ Chebyshev(Mean, Sd) UCL 9.19

Use 95\% Student's-t UCL 6.131 


$\begin{aligned} & \text { General UCL Statistics for Full Data Sets } \\ \text { User Selected Options } & \\ \text { From File } & \text { WorkSheet.wst } \\ \text { Full Precision } & \text { OFF } \\ \text { Confidence Coefficient } & 95 \% \\ \text { of Bootstrap Operations } & 2000 \\ & \end{aligned}$

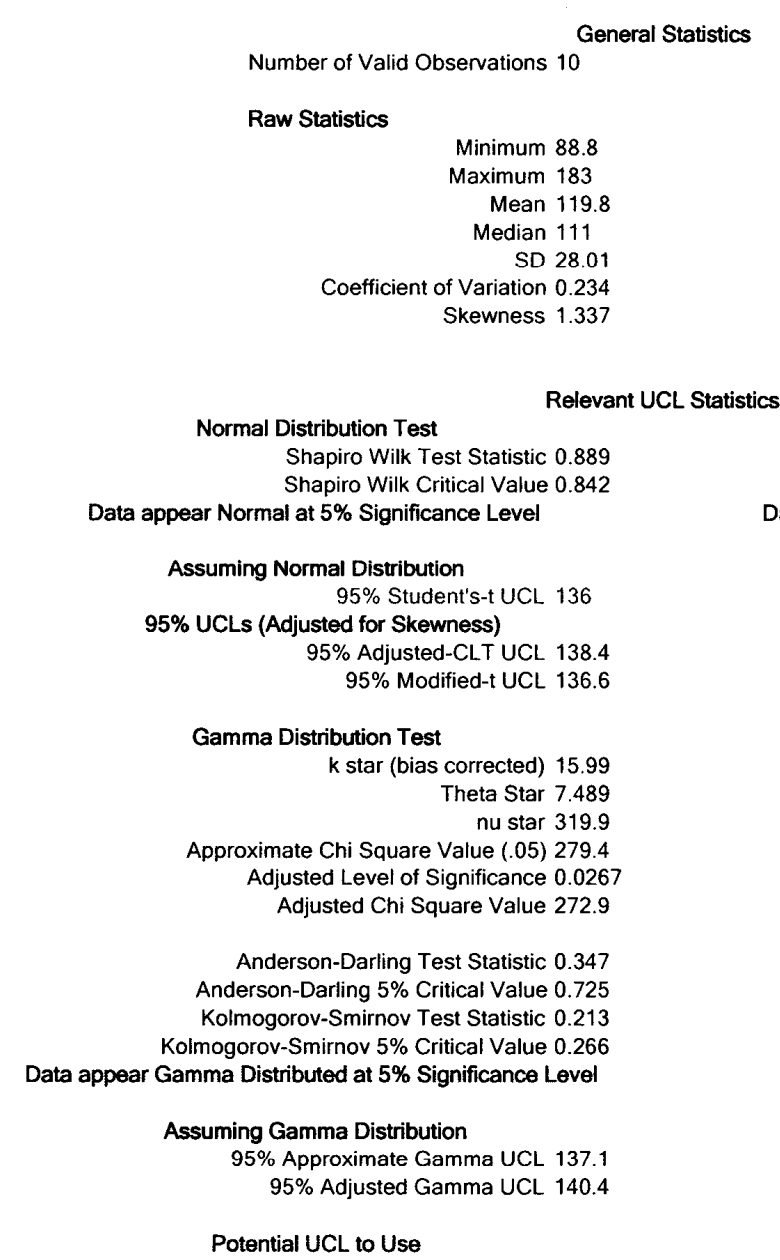

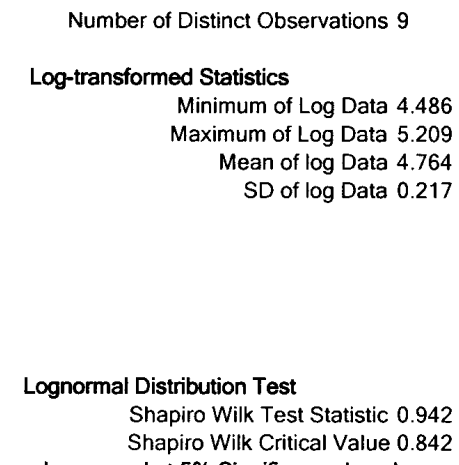

Data Distribution

Data appear Normal at 5\% Significance Level

Nonparametric Statistics

95\% CLT UCL 134.4 95\% Jackknife UCL 136 $95 \%$ Standard Bootstrap UCL 133.6 $95 \%$ Bootstrap-t UCL 146.1

95\% Hall's Bootstrap UCL 148 95\% Percentile Bootstrap UCL 134.9 $95 \%$ BCA Bootstrap UCL 137 95\% Chebyshev(Mean, Sd) UCL 158.4 97.5\% Chebyshev(Mean, Sd) UCL 175.1 99\% Chebyshev(Mean, Sd) UCL 207.9

Use 95\% Student's-t UCL 136 


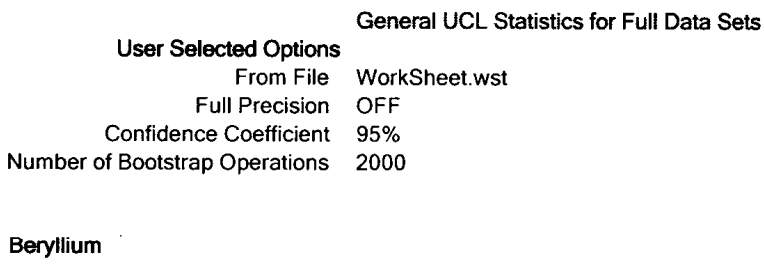

Beryllium

Number of Distinct Observations 7

Log-transformed Statistics

Minimum of Log Data -1.204

Maximum of Log Data -0.799

Mean of log Data -0.94

SD of log Data 0.14 


\author{
General UCL Statistics for Full Data Sets \\ User Selected Options \\ From File WorkSheet.wst \\ Full Precision OFF \\ Confidence Coefficient $95 \%$ \\ Number of Bootstrap Operations 2000 \\ Cadmium
}

Number of Distinct Observations 8

Log-transformed Statistics

Minimum of Log Data -1.47

Maximum of Log Data -0.635

Mean of log Data -1.012

SD of log Data 0.29
Mean 0.377

Median 0.39

Coefficient of Variation 0.277

Skewness -0.0329
Normal Distribution Test

Shapiro Wilk Test Statistic 0.934

Shapiro Wilk Critical Value 0.842

Data appear Normal at $5 \%$ Significance Level

Assuming Normal Distribution

$95 \%$ Student's-t UCL 0.437

95\% UCLs (Adjusted for Skewness)

$95 \%$ Adjusted-CLT UCL 0.431

95\% Modified-t UCL 0.437

Gamma Distribution Test

k star (bias corrected) 9.736 Theta Star 0.0387

nu star 194.7

Approximate Chi Square Value (.05) 163.4

Adjusted Level of Significance 0.0267

Adjusted Chi Square Value 158.5

Anderson-Darling Test Statistic 0.395

Anderson-Darling $5 \%$ Critical Value 0.725

Kolmogorov-Smirnov Test Statistic 0.178

Kolmogorov-Smirnov $5 \%$ Critical Value 0.266

Data appear Gamma Distributed at $5 \%$ Significance Level

Assuming Gamma Distribution

95\% Approximate Gamma UCL 0.449

95\% Adjusted Gamma UCL 0.463

Potential UCL to Use
Lognormal Distribution Test

Shapiro Wilk Test Statistic 0.924

Shapiro Wilk Critical Value 0.842

Data appear Lognormal at $5 \%$ Significance Level

Assuming Lognormal Distribution

95\% H-UCL 0.458

$95 \%$ Chebyshev (MVUE) UCL 0.529

97.5\% Chebyshev (MVUE) UCL 0.595

$99 \%$ Chebyshev (MVUE) UCL 0.724

Data Distribution

Data appear Normal at $5 \%$ Significance Level

Nonparametric Statistics

95\% CLT UCL 0.431 $95 \%$ Jackknife UCL 0.437

95\% Standard Bootstrap UCL 0.429

$95 \%$ Bootstrap-t UCL 0.434

$95 \%$ Hall's Bootstrap UCL 0.424

95\% Percentile Bootstrap UCL 0.426

95\% BCA Bootstrap UCL 0.43

95\% Chebyshev(Mean, Sd) UCL 0.521

97.5\% Chebyshev(Mean, Sd) UCL 0.583

$99 \%$ Chebyshev(Mean, Sd) UCL 0.705

Use $95 \%$ Student's-t UCL 0.437 
General UCL Statistics for Full Data Sets

User Selected Options

From File WorkSheet.wst

Full Precision OFF

Confidence Coefficient 95\%

Number of Bootstrap Operations 2000

Chromium

Number of Valid Observations 10

General Statistics

Raw Statistics

$$
\begin{array}{r}
\text { Minimum } 12.5 \\
\text { Maximum } 20.6 \\
\text { Mean } 17.04 \\
\text { Median } 16.85 \\
\text { SD } 2.793 \\
\text { Coefficient of Variation } 0.164
\end{array}
$$$$
\text { Skewness }-0.169
$$

Number of Distinct Observations 10

Log-transformed Statistics

Minimum of Log Data 2.526

Maximum of Log Data 3.025

Mean of log Data 2.823

SD of log Data 0.169

Normal Distribution Test

Relevant UCL Statistics

Shapiro Wilk Test Statistic 0.948

Shapiro Wilk Critical Value 0.842

Data appear Normal at $5 \%$ Significance Level

Assuming Normal Distribution

95\% Student's-t UCL 18.66

95\% UCLs (Adjusted for Skewness)

95\% Adjusted-CLT UCL 18.44

95\% Modified-t UCL 18.65

Gamma Distribution Test

k star (bias corrected) 28.07

Theta Star 0.607

nu star 561.3

Approximate Chi Square Value (.05) 507.4

Adjusted Level of Significance 0.0267

Adjusted Chi Square Value 498.4

Anderson-Darling Test Statistic 0.258

Anderson-Darling $5 \%$ Critical Value 0.724

Kolmogorov-Smirnov Test Statistic 0.153

Kolmogorov-Smirnov $5 \%$ Critical Value 0.266

Data appear Gamma Distributed at $5 \%$ Significance Level

Assuming Gamma Distribution

95\% Approximate Gamma UCL 18.85

95\% Adjusted Gamma UCL 19.19

Potential UCL to Use

Use $95 \%$ Student's-t UCL 18.66

Lognormal Distribution Test

Shapiro Wilk Test Statistic 0.945 Shapiro Wilk Critical Value 0.842

Data appear Lognormal at $5 \%$ Significance Level

Assuming Lognormal Distribution

95\% H-UCL 18.95

95\% Chebyshev (MVUE) UCL 21.02

97.5\% Chebyshev (MVUE) UCL 22.74

99\% Chebyshev (MVUE) UCL. 26.11

Data Distribution

Data appear Normal at 5\% Significance Level

Nonparametric Statistics

95\% CLT UCL 18.49 95\% Jackknife UCL 18.66

95\% Standard Bootstrap UCL 18.39 95\% Bootstrap-t UCL 18.59 95\% Hall's Bootstrap UCL 18.35

95\% Percentile Bootstrap UCL 18.42 95\% BCA Bootstrap UCL 18.32

$95 \%$ Chebyshev(Mean, Sd) UCL 20.89

97.5\% Chebyshev(Mean, Sd) UCL 22.55

$99 \%$ Chebyshev(Mean, Sd) UCL 25.83 
User Selected Options

General UCL Statistics for Full Data Sets

From File WorkSheet.wst

Full Precision OFF

Confidence Coefficient $95 \%$

Number of Bootstrap Operations 2000

Lead

\author{
General Statistics \\ Number of Valid Observations 10 \\ Raw Statistics \\ Minimum 6.8 \\ Maximum 22 \\ Mean 10.92 \\ Median 8.95 \\ SD 5.01 \\ Coefficient of Variation 0.459 \\ Skewness 1.76 \\ Relevant UCL Statistics \\ Shapiro Wilk Test Statistic 0.716 \\ Shapiro Wilk Critical Value 0.842 \\ Data not Normal at $5 \%$ Significance Level \\ Assuming Normal Distribution \\ 95\% Student's-t UCL 13.82 \\ 95\% UCLs (Adjusted for Skewness) \\ 95\% Adjusted-CLT UCL 14.47 \\ $95 \%$ Modified-t UCL 13.97 \\ Gamma Distribution Test \\ k star (bias corrected) 4.965 \\ Theta Star 2.199 \\ nu star 99.31 \\ Approximate Chi Square Value (.05) 77.32 \\ Adjusted Level of Significance 0.0267 \\ Adjusted Chi Square Value 73.95 \\ Anderson-Darling Test Statistic 1.139 \\ Anderson-Darling $5 \%$ Critical Value 0.728 \\ Kolmogorov-Smirnov Test Statistic 0.341 \\ Kolmogorov-Smirnov $5 \%$ Critical Value 0.267 \\ Data not Gamma Distributed at $5 \%$ Significance Level \\ Assuming Gamma Distribution \\ 95\% Approximate Gamma UCL 14.03 \\ 95\% Adjusted Gamma UCL 14.66 \\ Potential UCL to Use
}

Number of Distinct Observations 10

Log-transformed Statistics

Minimum of Log Data 1.917

Maximum of Log Data 3.091

Mean of log Data 2.317 SD of $\log$ Data 0.377

\author{
Lognormal Distribution Test \\ Shapiro Wilk Test Statistic 0.803 \\ Shapiro Wilk Critical Value 0.842 \\ Data not Lognormal at $5 \%$ Significance Level
}

Assuming Lognormal Distribution

$95 \%$ H-UCL 14.13

95\% Chebyshev (MVUE) UCL 16.51

97.5\% Chebyshev (MVUE) UCL 18.97

99\% Chebyshev (MVUE) UCL 23.81

Data Distribution

Data do not follow a Discernable Distribution (0.05)

\section{Nonparametric Statistics}

$95 \%$ CLT UCL 13.53 $95 \%$ Jackknife UCL 13.82

95\% Standard Bootstrap UCL 13.39 95\% Bootstrap-t UCL 23.21

$95 \%$ Hall's Bootstrap UCL 32.22

95\% Percentile Bootstrap UCL 13.64

95\% BCA Bootstrap UCL 14.27

95\% Chebyshev(Mean, Sd) UCL 17.83

$97.5 \%$ Chebyshev(Mean, Sd) UCL 20.81

99\% Chebyshev(Mean, Sd) UCL 26.68

Use 95\% Student's-t UCL 13.82 or $95 \%$ Modified-t UCL 13.97 


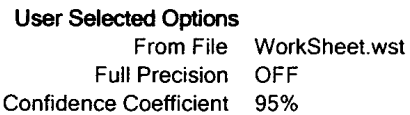

Mercury
Number of Distinct Observations 10

Log-transformed Statistics

Minimum of Log Data -4.51

Maximum of Log Data -0.654

Mean of log Data -3.157

SD of log Data 1.176

edian 0.028

SD 0.156

Skewness 2.758

Normal Distribution Test

Relevant UCL Statistics

Shapiro Wilk Test Statistic 0.563

Shapiro Wilk Critical Value 0.842

Data not Normal at $5 \%$ Significance Level

Lognormal Distribution Test

Shapiro Wilk Test Statistic 0.86 Shapiro Wilk Critical Value 0.842

Assuming Normal Distribution

95\% Student's-t UCL 0.184

95\% UCLs (Adjusted for Skewness)

95\% Adjusted-CLT UCL 0.22

95\% Modified-t UCL 0.191

Gamma Distribution Test

k star (bias corrected) 0.601

Theta Star 0.155 nu star 12.02

Approximate Chi Square Value (.05) 5.239

Adjusted Level of Significance 0.0267

Adjusted Chi Square Value 4.486

Anderson-Darling Test Statistic 1.106

Anderson-Darling 5\% Critical Value 0.757

Kolmogorov-Smirnov Test Statistic 0.35

Kolmogorov-Smirnov $5 \%$ Critical Value 0.276

Data not Gamma Distributed at 5\% Significance Level

\section{Assuming Gamma Distribution}

95\% Approximate Gamma UCL 0.214

95\% Adjusted Gamma UCL 0.249

Potential UCL to Use

Data appear Lognormal at $5 \%$ Significance Level

\section{Assuming Lognormal Distribution}

95\% H-UCL 0.332

95\% Chebyshev (MVUE) UCL 0.208

97.5\% Chebyshev (MVUE) UCL 0.265

$99 \%$ Chebyshev (MVUE) UCL 0.377

Data Distribution

Data appear Lognormal at 5\% Significance Level

Nonparametric Statistics

95\% CLT UCL 0.174 95\% Jackknife UCL 0.184

95\% Standard Bootstrap UCL 0.172 95\% Bootstrap-t UCL 0.394 $95 \%$ Hall's Bootstrap UCL 0.421

95\% Percentile Bootstrap UCL 0.184 95\% BCA Bootstrap UCL 0.221

$95 \%$ Chebyshev(Mean, Sd) UCL 0.308

97.5\% Chebyshev(Mean, Sd) UCL 0.401

$99 \%$ Chebyshev(Mean, Sd) UCL 0.584

Use $95 \%$ Chebyshev (MVUE) UCL 0.208 


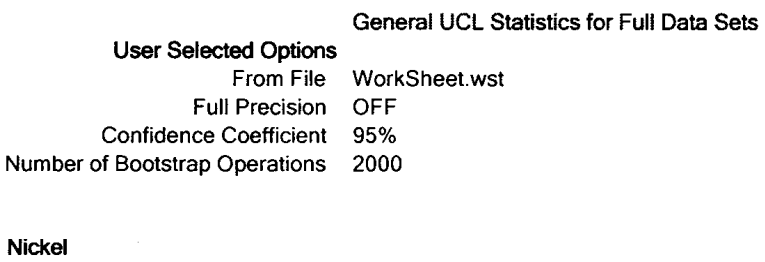

Nickel

\author{
General Statistics \\ Number of Valid Observations 10 \\ Raw Statistics
Minimum 13.8
Maximum 20.6
Mean 16.44
Median 15.95
SD 1.964 \\ Coefficient of Variation 0.119 \\ Skewness 0.96 \\ Relevant UCL Statistics \\ Normal Distribution Test \\ Shapiro Wilk Test Statistic 0.946 \\ Shapiro Wilk Critical Value 0.842 \\ Data appear Normal at 5\% Significance Level \\ Assuming Normal Distribution \\ 95\% Student's-t UCL 17.58 \\ 95\% UCLs (Adjusted for Skewness) \\ 95\% Adjusted-CLT UCL 17.66 \\ 95\% Modified-t UCL 17.61 \\ Gamma Distribution Test \\ k star (bias corrected) 57.18 \\ Theta Star 0.288 \\ nu star 1144 \\ Approximate Chi Square Value (.05) 1066 \\ Adjusted Level of Significance 0.0267 \\ Adjusted Chi Square Value 1053 \\ Anderson-Darling Test Statistic 0.233 \\ Anderson-Darling $5 \%$ Critical Value 0.724 \\ Kolmogorov-Smirnov Test Statistic 0.182 \\ Kolmogorov-Smirnov $5 \%$ Critical Value 0.266 \\ Data appear Gamma Distributed at 5\% Significance Level \\ Assuming Gamma Distribution \\ 95\% Approximate Gamma UCL 17.64 \\ 95\% Adjusted Gamma UCL 17.85 \\ Potential UCL to Use
}

Number of Distinct Observations 10

Log-transformed Statistics

Minimum of Log Data 2.625

Maximum of Log Data 3.025

Mean of log Data 2.794

SD of $\log$ Data 0.116

Lognormal Distribution Test

Shapiro Wilk Test Statistic 0.969

Shapiro Wilk Critical Value 0.842

Use 95\% Student's-t UCL 17.58 


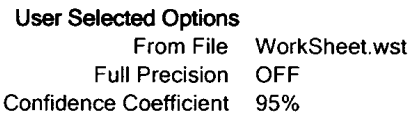

Silver
Number of Distinct Observations 8

Log-transformed Statistics

Minimum of Log Data -2.12

Maximum of Log Data -0.635

Mean of log Data -1.062

SD of log Data 0.402
Normal Distribution Test

Shapiro Wilk Test Statistic 0.891

Shapiro Wilk Critical Value 0.842

Data appear Normal at $5 \%$ Significance Level

Assuming Normal Distribution

$95 \%$ Student's-t UCL 0.428

95\% UCLs (Adjusted for Skewness)

95\% Adjusted-CLT UCL 0.408

95\% Modified-t UCL 0.426

Gamma Distribution Test

k star (bias corrected) 6.282 Theta Star 0.0583

nu star 125.6

Approximate Chi Square Value (.05) 100.7

Adjusted Level of Significance 0.0267

Adjusted Chi Square Value 96.88

Anderson-Darling Test Statistic 0.936

Anderson-Darling 5\% Critical Value 0.726

Kolmogorov-Smirnov Test Statistic 0.292

Kolmogorov-Smirnov $5 \%$ Critical Value 0.267

Data not Gamma Distributed at $5 \%$ Significance Level

\section{Assuming Gamma Distribution}

95\% Approximate Gamma UCL 0.456

95\% Adjusted Gamma UCL 0.475

Potential UCL to Use
Lognormal Distribution Test

Shapiro Wilk Test Statistic 0.731

Shapiro Wilk Critical Value 0.842

Data not Lognormal at $5 \%$ Significance Level

Assuming Lognormal Distribution

95\% H-UCL 0.496

95\% Chebyshev (MVUE) UCL 0.58

97.5\% Chebyshev (MVUE) UCL 0.67

$99 \%$ Chebyshev (MVUE) UCL 0.847

Data Distribution

Data appear Normal at $5 \%$ Significance Leve

Nonparametric Statistics

95\% CLT UCL 0.421 95\% Jackknife UCL 0.428

95\% Standard Bootstrap UCL 0.419 95\% Bootstrap-t UCL 0.416

95\% Hall's Bootstrap UCL, 0.414 95\% Percentile Bootstrap UCL 0.414

95\% BCA Bootstrap UCL 0.408

95\% Chebyshev(Mean, Sd) UCL 0.513

97.5\% Chebyshev(Mean, Sd) UCL 0.576

$99 \%$ Chebyshev(Mean, Sd) UCL 0.701

Use $95 \%$ Student's-t UCL 0.428 


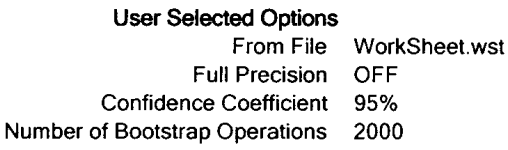

Thallium

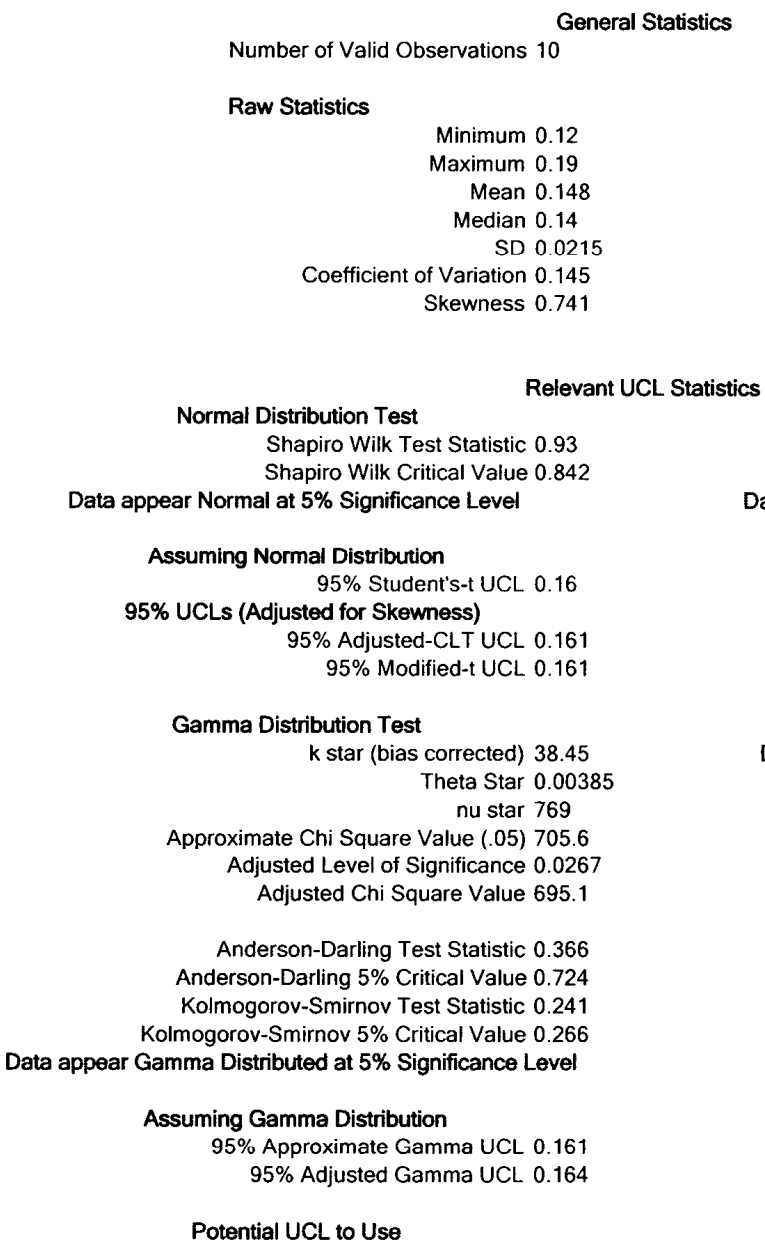

Potential UCL to Use

Lognormal Distribution Test

Shapiro Wilk Test Statistic 0.948 Shapiro Wilk Critical Value 0.842

Data appear Lognormal at 5\% Significance Level

Assuming Lognormal Distribution

95\% H-UCL 0.161

95\% Chebyshev (MVUE) UCL 0.177

97.5\% Chebyshev (MVUE) UCL 0.189

$99 \%$ Chebyshev (MVUE) UCL 0.214

Data Distribution

Data appear Normal at $5 \%$ Significance Level

Nonparametric Statistics

95\% CLT UCL 0.159 $95 \%$ Jackknife UCL 0.16

95\% Standard Bootstrap UCL 0.158 $95 \%$ Bootstrap-t UCL 0.163

$95 \%$ Hall's Bootstrap UCL 0.163 95\% Percentile Bootstrap UCL 0.159 95\% BCA Bootstrap UCL 0.161 95\% Chebyshev(Mean, Sd) UCL 0.178

97.5\% Chebyshev(Mean, Sd) UCL 0.19

99\% Chebyshev(Mean, Sd) UCL 0.216

Use $95 \%$ Student's-t UCL 0.16 


\author{
User Selected Options \\ From File WorkSheet.wst \\ Full Precision OFF \\ Confidence Coefficient $95 \%$ \\ Number of Bootstrap Operations 2000 \\ Vanadium
}

Number of Distinct Observations 10

Log-transformed Statistics

Minimum of Log Data 3.006

Maximum of Log Data 3.506

Mean of log Data 3.25

SD of log Data 0.158

Mean 26.08

SD 4.073

Coefficient of Variation 0.156

Skewness 0.155

Normal Distribution Test

Relevant UCL Statistics

Shapiro Wilk Test Statistic 0.968

Shapiro Wilk Critical Value 0.842

Data appear Normal at $5 \%$ Significance Level

Lognormal Distribution Test

Shapiro Wilk Test Statistic 0.965

Shapiro Wilk Critical Value 0.842

Data appear Lognormal at $5 \%$ Significance Level

Assuming Normal Distribution

$95 \%$ Student's-t UCL 28.44

95\% UCLs (Adjusted for Skewness)

95\% Adjusted-CLT UCL 28.27

95\% Modified-t UCL 28.45

Gamma Distribution Test

k star (bias corrected) 31.71

Theta Star 0.823 nu star 634.2

Approximate Chi Square Value (05) 576.7

Adjusted Level of Significance 0.0267

Adjusted Chi Square Value 567.2

Anderson-Darling Test Statistic 0.227

Anderson-Darling 5\% Critical Value 0.724

Kolmogorov-Smirnov Test Statistic 0.172

Kolmogorov-Smirnov 5\% Critical Value 0.266

Data appear Gamma Distributed at $5 \%$ Significance Level

Assuming Gamma Distribution

95\% Approximate Gamma UCL 28.68

95\% Adjusted Gamma UCL 29.16

Potential UCL to Use

Assuming Lognormal Distribution

95\% H-UCL 28.78

95\% Chebyshev (MVUE) UCL 31.76

97.5\% Chebyshev (MVUE) UCL 34.22

$99 \%$ Chebyshev (MVUE) UCL 39.05

Data Distribution

Data appear Normal at 5\% Significance Level

Nonparametric Statistics

95\% CLT UCL 28.2 95\% Jackknife UCL 28.44

95\% Standard Bootstrap UCL 28.07 95\% Bootstrap-t UCL 28.55 $95 \%$ Hall's Bootstrap UCL 28.39

95\% Percentile Bootstrap UCL 28.12

95\% BCA Bootstrap UCL 27.96

95\% Chebyshev(Mean, Sd) UCL 31.69

97.5\% Chebyshev(Mean, Sd) UCL 34.12

$99 \%$ Chebyshev(Mean, Sd) UCL 38.9

Use $95 \%$ Student's-t UCL 28.44 


\section{User Selected Options}

From File WorkSheet.wst

Full Precision OFF

Confidence Coefficient $95 \%$

Number of Bootstrap Operations 2000

Zinc

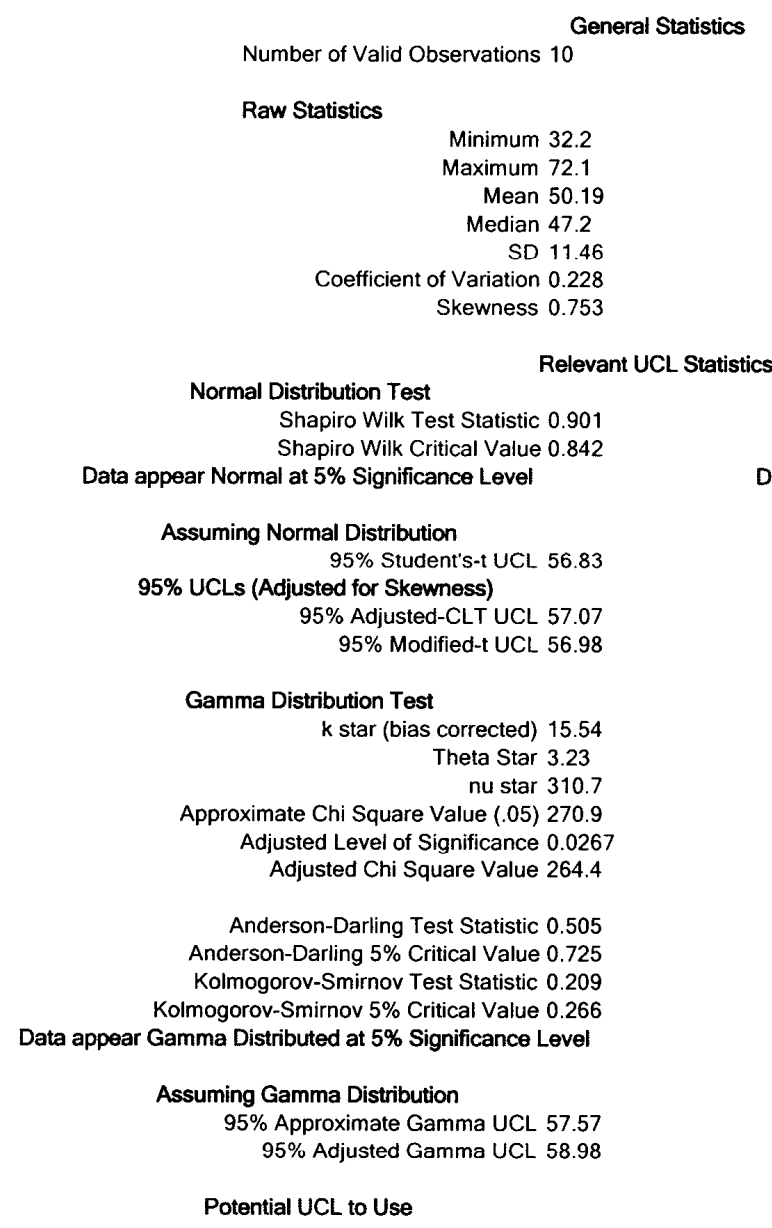

Number of Distinct Observations 10

Log-transformed Statistics

Minimum of Log Data 3.472

Maximum of Log Data 4.278

Mean of log Data 3.893

SD of log Data 0.225

\author{
Lognormal Distribution Test \\ Shapiro Wilk Test Statistic 0.924 \\ Shapiro Wilk Critical Value 0.842 \\ Data appear Lognormal at $5 \%$ Significance Level
}

\section{Assuming Lognormal Distribution}

95\% H-UCL 58.01

$95 \%$ Chebyshev (MVUE) UCL 65.78

97.5\% Chebyshev (MVUE) UCL 72.53

$99 \%$ Chebyshev (MVUE) UCL 85.78

Data Distribution

Data appear Normal at $\mathbf{5 \%}$ Significance Level

\section{Nonparametric Statistics}

95\% CLT UCL 56.15 95\% Jackknife UCL 56.83

95\% Standard Bootstrap UCL 55.65 $95 \%$ Bootstrap-t UCL 60.53

$95 \%$ Hall's Bootstrap UCL 69.62

95\% Percentile Bootstrap UCL 56.56

95\% BCA Bootstrap UCL 56.66

$95 \%$ Chebyshev(Mean, Sd) UCL 65.99

97.5\% Chebyshev(Mean, Sd) UCL 72.82

$99 \%$ Chebyshev(Mean, Sd) UCL 86.25

Use $95 \%$ Student's-t UCL 56.83 